\author{
UNIVER SIDADE DE SÃO PAULO \\ FACULDADE DE FILOSOFIA LETRAS \\ E CIÊNCIASHUMANAS. \\ PROGRAMA DE PÓS-GRADUAÇÃO EM HISTÓRIA.
}

\title{
FORMAÇÃO ECONÔMICA E SOCIAL DE FOZ DO IGUAÇU: um estudo sobre as memórias constitutivas da cidade (1970-2008).
}

\section{APARECIDA DARC DE SOUZA}

São Paulo, SP.

2009 


\section{APARECIDA DARC DE SOUZA}

\section{FORMAÇÃO ECONÔMICA E SOCIAL DE FOZ DO IGUAÇU: um estudo sobre as memórias constitutivas da cidade (1970-2008).}

Tese apresentada ao Programa de Pós-Graduação em História, da Universidade de São Paulo, como parte dos requisitos necessários à obtenção do título de Doutor em História Econômica, tendo como orientador 0 Professor Doutor Osvaldo Coggiola.

São Paulo, SP.

2009 


\section{FORMAÇÃO E CONÔMICA E SOCIAL DE FOZ DO IGUAÇU: um estudo sobre as memórias constitutivas da cidade (1970-2008).}

Tese apresentada ao Programa de Pós-Graduação em História, da Universidade de São Paulo, como parte dos requisitos necessários à obtenção do título de Doutor em História Econômica.

Aprovada em 07. de Maio de 2009

Prof. Dr. Osval do Coggiola. Departamento de História. USP. Orientador.

Prof. Dr. Antonio de Almeida

Prof. Dr. Marcos Silva

Prof. Dr. Heloísa de Faria Cruz

Prof. Dr. J orge Luiz da Silva Grespan 


\section{AGRADE CIMENTOS}

A conclusão desta tese só foi possível graças ao apoio e solidariedade de muitas pessoas, às quais sou profundamente grata. Assim é que agradeço:

ao meu orientador, Osvaldo Coggiola, pela confiança, pela paciência e pelo apoio nos momentos difíceis.

a todos os trabalhadores, pelas entrevistas concedidas e por terem me ajudado a realizar outras entrevistas por meio de suas sugestões e indicações;

aos funcionários das seguintes instituições, pela colaboração no trabalho de pesquisa: Biblioteca Municipal de Foz do I guaçu, Biblioteca de Turismo Eufrida Engels, Secretaria Municipal de Planejamento, Receita Federal, Biblioteca Pública do Paraná, Arquivo Público do Paraná, IPARDES, Arquivo Nacional do Exército;

aos professores Marcos Silva e Raquel Glezer, pelas críticas e sugestões na banca de qualificação.

à CAPES, pelo incentivo à pesquisa;

a Antônio pelo apoio e incentivo cotidianos, pela leitura atenta e crítica que foram fundamentais para a condusão do trabalho.

a Katiucya e Maria, Carlos e Cida, Eric e Aline, J anete e Fred, pelo carinho e a hospitalidade;

a Wiliam, Cris, Roniel, Odirlei, Bia, Enes e Maurício. Graças aos seus esforços e contatos com amigos, parentes e vizinhos, consegui realizar inúmeras entrevistas;

a Marilia, por toda sua dedicação e empenho na revisão do texto e normalização da tese. 


\section{RESUMO}

SOUZA, Aparecida Darc de. FORMAÇÃO ECONÔMICA E SOCIAL DE FOZ DO IGUAÇU: um estudo sobre as memórias constitutivas da cidade (1970-2008). 2008. 218p. Tese (Doutorado em História)-Universidade de São Paulo. São Paulo, 2009.

O intenso e acelerado crescimento urbano vivido pela cidade de Foz do Iguaçu (PR), a partir da década de 1970, foi marcado pela elaboração de uma memória cujo conteúdo moldasse uma visão histórica de Foz do Iguaçu como uma cidade que, desde sua fundação, estava destinada a ser um centro de atração turística. As questões desenvolvidas, nesta tese, centramse na problematização do processo de produção e reprodução desta memória a partir de fontes históricas escritas e orais. Neste sentido, este estudo buscou discutir a construção da memória dominante contrastando-a com as narrativas de vida de diversos trabalhadores em Foz do Iguaçu. Este procedimento metodológico permitiu questionar a memória dominante e seu principal argumento - a vocação turística da cidade -, abrindo possibilidades de discussão de outras memórias sobre a cidade.

PALAVRAS-CHAVE: Foz do Iguaçu. Memória. Cidade. Turismo. Trabalhadores.

\section{ABSTRACT}

Urban growth as intense and hasty as it was experienced by the City of Foz do Iguaçu (State of Paraná, Brazil) from the 1970's on, was marked by the elaboration of a memory such that its content would shape a historical vision of Foz do Iguaçu as a city that was meant to be, since it was founded, a center of touristic attraction. The research questions herein developed focused upon, problematized the process of producing and reproducing that memory, based on written and oral historical sources. In this way, the study discussed the construction of the dominant memory contrasting it to the life history of several workers in Foz do Iguaçu. This methodological procedure allowed of questioning the dominant memory and its main argument - the City's touristic vocation -, thereby opening further possibilities for the discussion of other memories about the City.

KEYWORDS: Foz do Iguaçu. Memory. City. Tourism. Workers. 


\section{LISTA DE ILUSTRAÇÕES}

\section{MAPAS}

MAPA 1. Localização das Cataratas em relação a Foz do Iguaçu e Puerto Iguazu

MAPA 2. Zoneamento urbano de Foz do Iguaçu

MAPA 3. Localização do Município de Foz do Iguaçu 24

MAPA 4. Principais obrages no Oeste do Paraná 32

MAPA 5. Localização dos portos da Tríplice Fronteira em 1957 174

\section{TABE LAS}

TABELA 1. Meios de hospedagem: aberturas de alvará (1959 - 2005) .. 146

TABELA 2. Agências de turismo: abertura de alvará (1967-2005) .......... 147

TABELA 3. Evolução da PEA de Foz do Iguaçu ..................................... 149

TABELA 4. Pessoas de 10 anos ou mais, por rendimento médio mensal e sexo, em Foz do Iguaçu (1980) 


\title{
LISTA DE ABREVIATURAS E SIGLAS
}

\author{
ACIFI - Associação Comercial de Industrial de Foz do Iguaçu \\ AR - Argentina \\ CODEM - Conselho Municipal de Desenvolvimento \\ EMBRATUR - Empresa Brasileira de Turismo \\ IBGE - Instituto Brasileiro de Geografia e Estatística \\ IPARDES - Instituto Paranaense de Desenvolvimento Econômico e Social \\ MG - Minas Gerais [Estado de] \\ PDDI -FI - Plano de Diretor de Desenvolvimento Integrado - Foz do Iguaçu \\ PDS - Partido Democrático Social \\ PDT - Partido Democrático Trabalhista \\ PDU - Plano de Desenvolvimento Urbano \\ PEA - População Economicamente Ativa \\ PIB - Produto Interno Bruto \\ PMDB - Partido do Movimento Democrático Brasileiro. \\ PMFI - Prefeitura Municipal de Foz do Iguaçu \\ PND - Plano Nacional de Desenvolvimento \\ PR - Paraná [Estado do] \\ PT - Partido dos Trabalhadores \\ PY - Paraguai [Paraguay] \\ SMTU - Secretaria Municipal de Turismo \\ SMPU - Secretaria Municipal de Planejamento Urbano
}




\section{SU MÁRIO}

INTRODUÇÃO

CAPÍTULO 1. O tema e o objeto na historiografia: a cidade de Foz do Iguaçu

CAPÍTULO 2. O nascimento da cidade turística: a construção da memória dominante

$2.1 \mathrm{O}$ mito das origens

2.2 As elites e a construção da memória: o mito do pioneiro

CAPÍTULO 3. Os trabalhadores e a memória dominante

3.1 Referências para discussão

3.2 Reivindicando a memória

3.3 A vocação turística revisitada

CAPÍTULO 4. Memórias confrontadas: as cidades dos trabalhadores ... 156

4.1 Cidade, trabalho e fronteira 158

4.2 Itaipu: uma oportunidade que não se realizou para todos os trabalhadores

4.3 O turismo na perspectiva dos trabalhadores 


\section{INTRODUÇÃO}

Terra das Cataratas ${ }^{1}$. Este é o slogan oficial que apresenta a cidade de Foz do Iguaçu ao Brasil e ao mundo. As fotos publicitárias e as propagandas oficiais centram-se neste ponto, refletindo uma imagem planejada de uma cidade portadora de uma função: o turismo. Absolutamente tudo parece girar em torno dessa atividade. As ocupações, os espaços, os monumentos e a própria história são apresentados como se estivessem, inevitavelmente, articulados a esta função.

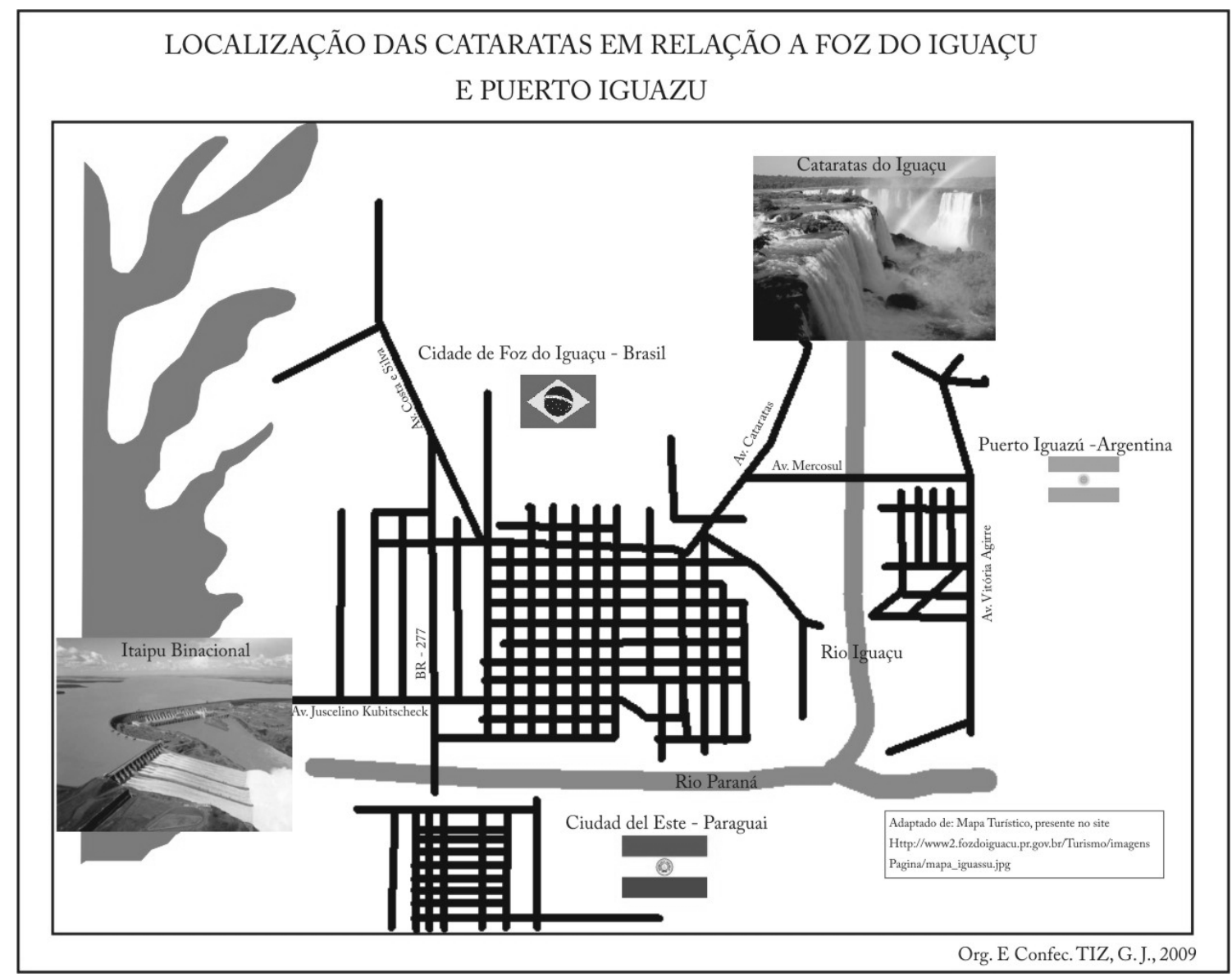

MAPA 1. L ocalização das Cataratas em relação a F oz do Iguaçu e Puerto Iguazu.

\footnotetext{
${ }^{1}$ As Cataratas do Iguaçu são formadas por 275 quedas d'água, no rio Iguaçu, e fazem parte do patrimônio do Parque Nacional do Iguaçu, no Estado do Paraná (Brasil), e do patrimônio do Parque Nacional do Iguazú, na Província de Missiones (Argentina). A poucos quilômetros das cataratas estão localizadas as cidades de Foz do Iguaçu, do lado brasileiro, e Puerto Iguazú, em território argentino. (V. Mapa 1).
} 
Meu primeiro contato com a cidade de foz do Iguaçu foi mediado por essa visão. Quando fui convidada para trabalhar como professora de História, em Foz do Iguaçu, no ano de 2001, esta era a principal - e quase única - informação que eu tinha sobre aquela cidade. Mas fui motivada pelo trabalho. Aliás, levei algum tempo para visitar as cataratas. À medida que minha permanência na cidade se prolongava, novas experiências pautavam outras visões de Foz, que não se circunscreviam apenas ao turismo. Conversando com os primeiros alunos que tive, pude ampliar minha visão acerca da cidade, alcançando perspectivas que não se aliavam à idéia de "terras das cataratas". Dessas novas percepções, propus uma pesquisa de fôlego curto sobre a cidade e a produção das memórias, que foi desenvolvida na disciplina História e Memória, no ano de 2003. Portanto, foi de um estranhamento inicial, somado a um ensaio intelectual, que cheguei ao projeto de doutorado ora desenvolvido em tese.

Essa idéia inicial projetou-se ao longo de todo o trabalho de campo e foi sendo refinada pelas atividades disciplinares do Programa de Pós-graduação em História Econômica, nos contatos com a orientação e nos momentos de discussão, quando tive oportunidade de discuti-la em eventos ou com outros colegas. O resultado dessa trajetória encontra-se numa tentativa de problematizar determinada vocação turística da cidade, construída pelas classes dominantes, ao longo das décadas de 1970 e 1990.

Visitas turísticas à Foz do Iguaçu não eram propriamente uma novidade, na década de 1970. Ao contrário, já existia e baseava-se, fundamentalmente, na visita às Cataratas do Rio Iguaçu. $\mathrm{O}$ que havia de novo era a elaboração de uma proposição que identificava, nessa atividade, o núcleo para onde deveriam convergir todos os investimentos públicos municipais e, principalmente, federais. Desde então, o turismo passou a ser definido como a principal atividade econômica local.. Desse modo, a construção de uma memória de Foz do Iguaçu como cidade turística foi uma estratégia importante de legitimação dos interesses dos 
defensores dessa proposição: o domínio sobre o passado, ou melhor, sobre seu significado no presente.

Os esforços dos grupos dominantes locais dirigiram-se à produção de uma memória cujo conteúdo fosse capaz de moldar uma visão histórica de Foz do Iguaçu como uma cidade que, desde sua fundação, estaria destinada a ser um centro de atração turística. A constituição dessa visão, como hegemônica, legitimaria os projetos e interesses econômicos de tais grupos. Tratava-se, portanto, de uma tentativa de articulação da história desses grupos com a história da própria cidade.

A problematização desta visão sobre o passado da cidade foi feita a partir da seguinte metodologia de pesquisa. Num primeiro momento, procurei conhecer quando, como, por que e por quem foi construída a idéia da vocação turística de Foz do Iguaçu. Nesta direção, busquei investigar a produção dessa memória, que articulava a história da cidade à história do turismo direcionada para as Cataratas. Para tanto, realizei levantamentos do acervo de publicações locais, apresentadas e divulgadas como instrumentos de registro da memória da cidade. Tal empreitada foi desenvolvida na Biblioteca de Turismo Eufrida Engels e na Biblioteca Pública Municipal, ambas em Foz do Iguaçu. Nesses levantamentos, encontrei livros, álbuns e revistas. Apesar dessa diversidade, observei que todas essas publicações foram confeccionadas, entre as décadas de 1970 e 1990, e dedicavam-se a identificar, no turismo, o fator histórico determinante do desenvolvimento da cidade. Nessas publicações, a memória de Foz do Iguaçu se confundia com a memória do turismo nas Cataratas do Iguaçu.

O curso da história da cidade, nessa literatura, apareceu determinado pela "condição natural" que a define como local privilegiado para a formação de um polo de turismo nacional e internacional. Organizando o tempo e moldando o passado, a história presente nas obras dos memorialistas constitui-se em "[...] instrumentos por meio dos quais as classes dirigentes mantêm seu poder" (CHESNEAUX, 1995, p.29, à medida que justifica e legitima o discurso e 
as práticas dos setores dominantes locais, que priorizam os investimentos públicos nas atividades turísticas e promovem as condições para ampliação das diferentes formas de reprodução e ampliação do capital.

Coincidindo com a percepção de Roncayolo (1986), uma primeira impressão menos incauta sobre esta imagem da cidade de Foz do Iguaçu certamente identifica que, no ato de construção desta, são imediatamente expulsas muitas experiências sociais. Estão ausentes os moradores e seus modos de viver; o trabalho e sua inserção num contexto de fronteira, com legislação tríplice e regras costumeiras muitas vezes diferenciadas entre si; os conflitos e as disputas que envolvem a apropriação e a produção cotidiana da cidade; enfim, estão ausentes as experiências sociais que contrastam com a imagem postulada oficialmente, cujo conteúdo e forma expressam-se em uma memória com vocação uníssona e que, como destacou Jacques Le Goff (1996, p.476), “é também um instrumento e um objeto de poder”. Assim, a cidade aparece como produto dos ideais das classes dominantes, como projeção de seus interesses e, praticamente, destituída de conflitos sociais.

Diante dessa problematização, o segundo momento da pesquisa buscou focalizar a cidade, a partir das memórias dos trabalhadores que nela residem, desde a década de 1960. Para criar as condições de produção dessas memórias, trabalhei com fontes orais. A realização de entrevistas constituiu-se em metodologia privilegiada de investigação da experiência de uma população que, no curso de sua vida, na cidade, teve pouca ou nenhuma chance de registrar, por meio da palavra impressa, suas propostas, suas reivindicações, sua luta, seu trabalho. Tratei, portanto de tentar chegar até as memórias dos grupos não hegemônicos, cuja voz foi, em muitas circunstâncias, silenciada pela memória oficial.

Tratei de investigar, a partir das memórias dos trabalhadores, também outras dimensões políticas e sociais da cidade, que não estavam presentes nos documentos oficiais e nos relatos comemorativos da memória das classes dominantes. Nessa perspectiva, ao estudar 
a cidade, a partir da vivência dos trabalhadores, esforcei-me para entendê-la com base nos modos de vida de todos os homens e mulheres cuja existência revelou-se marcada pela exploração do seu trabalho. Tal procedimento representou falar com eles, fora das instâncias oficiais de poder, no universo de suas próprias relações sociais e políticas. Investindo na compreensão de seus modos de vida, supus ser possível a reconstituição da cidade, analisando outros pontos de vista. E essa busca fez-me enfrentar as lembranças da cidade vivida pelos trabalhadores; ouvir suas queixas, seus registros, suas histórias. Nesses casos, muitas vezes seus olhares projetaram imagens da cidade marcadas por suas próprias trajetórias, sem se desfazerem do peso das instituições e dos relatos oficiais, mas reinterpretando-os à luz de suas experiências.

No trabalho de construção dos depoimentos, optei pela realização de entrevistas de histórias de vida, com homens e mulheres trabalhadores, que nasceram ou residem na cidade de Foz do Iguaçu, desde 1960. Esta forma de trabalho pareceu-me aquela que mais e melhor se articulava aos objetivos e propósitos desta pesquisa, pois as entrevistas de história de vida:

[...] têm como interesse o próprio indivíduo na história, incluindo sua trajetória desde a infância até o momento em que fala, passando pelos diversos acontecimentos e conjunturas que presenciou, vivenciou ou de que se inteirou. (ALBERTI, 1990, p.20).

À pesquisa interessou, sobretudo, os entrevistados, os trabalhadores, sua forma de construir suas memórias e o modo como estas relacionam sua trajetória de vida com a cidade de Foz do Iguaçu. Para isso, usei como parâmetro a classificação apresentada pela Secretaria Municipal de Planejamento Urbano (SMPU), de Foz do Iguaçu, que divide a cidade em zonas homogêneas (v. MAPA 2). 


\section{Zoneamento Urbano de Foz do Iguaçu}

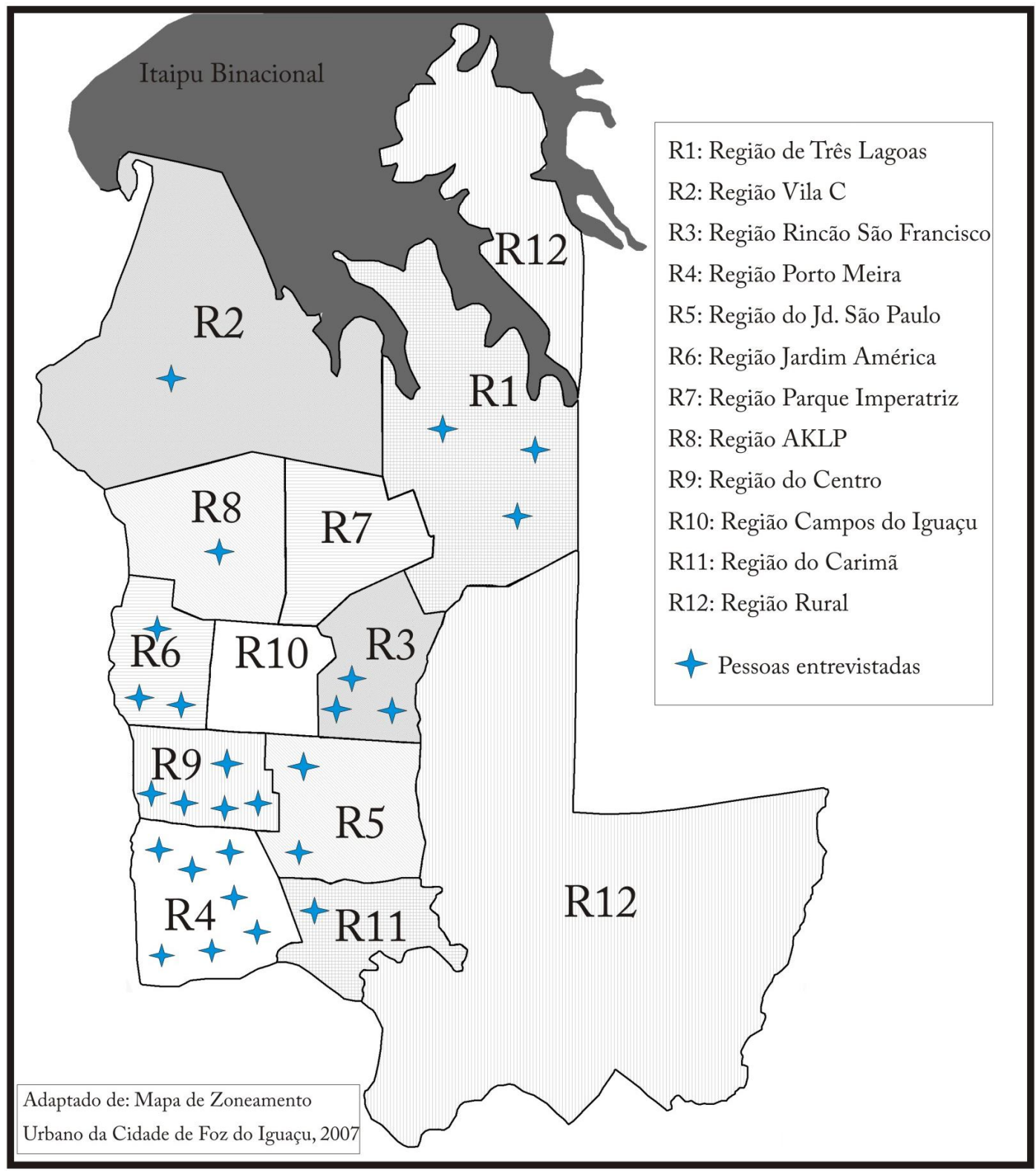

Org. E Conf. TIZ, G. J., 2009

MAPA 2. Zoneamento urbano de F oz do I guaçu.

FONTE: FOZ DO IGUAÇU (Prefeitura Municipal de): SMPU, 2007. [Legenda organizada pela autora] 
De maneira geral, o processo de produção dos depoimentos se pautou pela realização de entrevistas com trabalhadores que residiam, preferencialmente, em regiões diferentes de Foz do Iguaçu, desde a década de 1960.

Embora o processo de obtenção dos depoimentos tenha sido orientado pelos critérios identificados acima, a escolha dos entrevistados dependeu, também, de outros fatores. Nesse sentido, o meu período de docência, entre 2001 e 2004, em Foz do Iguaçu, foi determinante na localização dos entrevistados. Com o apoio de alguns ex-alunos e suas respectivas famílias, fui apresentada a diversos trabalhadores, em diferentes pontos da cidade. A partir daqueles, construí uma rede de contatos que culminou na produção de 22 entrevistas. Em função desta dinâmica, acabei entrevistando pessoas que tinham relações de parentesco entre si. Foi o caso do senhor Carlos, que é cunhado dos irmãos Adolfo e Luís. T. e por meio de cuja família cheguei ao senhor Adolfo; e foi este, por sua vez, quem me indicou seu irmão, Luís T., a partir de cuja recomendação entrevistei a senhora Guilhermina, sua prima.

Consegui realizar mais três entrevistas, por meio de outras estratégias: uma, a partir da indicação de uma funcionária de um asilo e outras duas, por indicação da Associação de Guias de Turismo de Foz do Iguaçu. Noutra direção, houve, também, um esforço de colher depoimentos de fiscais mais antigos da Receita Federal. O trabalho dos fiscais da Receita Federal privilegiou e privilegia o contato direto com a população local, que cruza a fronteira para ter acesso ao comércio, seja na Argentina, seja no Paraguai. Em muitas entrevistas, foi relatado, de modo recorrente, o hábito dos residentes de Foz do Iguaçu de comprar farinha de trigo, azeite etc., em Puerto Iguazu (AR) para revendê-los em Foz, nos anos de 1950 e 1960. Em outros momentos, de maneira mais velada, vários depoimentos informaram sobre a existência de um acentuado comércio ilegal de café e outros produtos com o Paraguai. Para muitos trabalhadores, esse envolvimento com o comércio de fronteira constituía-se numa 
forma de trabalho fortuito e(ou) permanente que gerava uma renda complementar. Nesse sentido, as entrevistas com os fiscais da Receita poderiam produzir um quadro mais amplo dos conflitos sociais e econômicos vividos pelos trabalhadores, na cidade de Foz do Iguaçu, a partir da década de 1970.

Porém, não foi possível entrevistar fiscais da Receita Federal com uma experiência de trabalho muito longa, em Foz. De modo geral, a justificativa oficial apresentada é de que os funcionários da Receita Federal tendem a não permanecer, por muito tempo, numa mesma região. Eles circulam por diferentes agências, ao longo de sua carreira, para evitar a criação de laços ou conflitos personificados com a sociedade local onde a Receita opera. Apesar da busca insistente, na própria agência local e no sindicato da categoria, não foi possível localizar nenhum fiscal que tenha atuado na cidade, a partir da década de 1960. Diante disso, foi realizada apenas uma entrevista com o fiscal que atua há mais tempo em Foz do Iguaçu, isto é, desde 1980.

Em sua maioria, foram relatos individuais. Apenas um deles foi realizado simultaneamente pela mulher e o marido. Ao todo, realizei 26 entrevistas, com 27 relatos de trabalhadores de diferentes regiões da cidade e de diferentes profissões. Porém, na produção da tese, não utilizei uma das entrevistas, uma vez que não foi possível transcrevê-la, diante da dificuldade de compreensão da fala do trabalhador de idade bastante avançada, cuja voz não foi adequadamente captada pelo gravador.

Desde o início, a pesquisa procurou privilegiar a realização de entrevistas com trabalhadores que pudessem, a partir de suas lembranças, abordar o passado da cidade desde, pelo menos, a década de 1960. Entretanto, o esforço para garantir que estes trabalhadores fossem de diferentes regiões da cidade implicou incorporar entrevistados mais jovens. Isso porque algumas dessas regiões, como Três Lagoas, São Francisco, Vila C começaram a ser 
urbanizadas, desde meados da década de 1970, quando teve início a construção da usina hidrelétrica de Itaipu. A maioria dos moradores dessas regiões se origina de uma população de trabalhadores que migrou para Foz do Iguaçu, justamente nessa época.

Nos relatos das trabalhadoras e trabalhadores entrevistados, repetia-se a narrativa de uma trajetória ocupacional bastante diversificada. Geralmente, para maioria dos entrevistados, essa trajetória começou no campo, junto às famílias, que viviam na condição de meeiras e (ou) pequenas proprietárias. Quando migraram para a cidade, ou quando a cidade chegou até eles, devido ao processo de urbanização, no caso daqueles que nasceram em Foz do Iguaçu, esses trabalhadores passaram a viver de diferentes ocupações, ao longo de sua vida.

O fato de a maioria dos entrevistados ter exercido mais de uma ocupação, durante suas vidas, e, sob muitos aspectos, atividades bastante díspares, quanto às formas de remuneração e às condições de trabalho, tornou ainda mais complexa a tarefa definir o perfil dos trabalhadores. Essa diversidade de ocupações não nos permitiu identificá-los pela profissão. Mas, por outro lado, em muitos casos, essa diversificação pôde constituir-se num importante referencial para investigarmos as dinâmicas econômicas da cidade, partindo da experiência destes trabalhadores, em Foz do Iguaçu. Para apresentar um panorama geral das ocupações identificadas nas entrevistas realizadas, podem ser citadas as seguintes: empregados de madeireiras, de olarias, empregadas domésticas, carpinteiros, pedreiros, canteiros, costureiras, cozinheiras, lavadeiras, vigias, trabalhadores de serviços gerais e de limpeza, eletricistas, operadores de máquinas, motoristas, vendedores de mercadorias da Argentina e Paraguai, entre outros.

Segue, abaixo, a relação das entrevistas utilizadas na pesquisa geradora desta tese. 


\section{Relação dos Trabalhadores entrevistados ${ }^{*}$.}

Adolfo, casado, 67 anos, aposentado, nasceu em 1941, na cidade de Cruz Machado (PR). Mora em Foz do Iguaçu, desde 1945. Trabalhou na roça, no comércio fronteiriço com a Argentina e, até aposentar-se, na manutenção de piscinas de hotéis. Desde que chegou a Foz do Iguaçu, o senhor Adolfo morou na região sul, próxima às margens do rio Iguaçu. Entrevista realizada em 12 de Janeiro de 2007, no bairro Vila Padre Monti,, Região do Porto Meira, na cidade de Foz do Iguaçu.

Alexandra, viúva, 70 anos, aposentada, nasceu em 1933, no estado de Minas Gerais. Mora em Foz do Iguaçu, desde 1967, aproximadamente. Ela e o marido eram trabalhadores rurais. Em Foz do Iguaçu, conseguiram adquirir uma pequena chácara, na região da Gleba Guarani. Tentaram a sorte na plantação de algodão, no Paraguai. Não deu certo. Acabaram voltando para Foz e passaram a viver e trabalhar na cidade. O marido trabalhou na obra de Itaipu, e ela passou a trabalhar como doméstica e auxiliar de serviços gerais, em condomínios e hotéis da cidade. Durante todo o período que viveu em Foz do Iguaçu, dona Alexandra morou na porção norte do município. Entrevista realizada em 10 de janeiro de 2007, no bairro Jardim bandeirante, Região Três Lagoas, na cidade de Foz do Iguaçu.

Avimar, casado, 55 anos. Mora em Foz do Iguaçu, desde 1977. Antes de vir para a cidade, ele e sua família trabalhavam no campo, como meeiros ou agregados. Trabalhou na construção da usina, durante 10 anos (1977-1987). Foi dispensado, quando foram concluídas as obras do setor no qual trabalhava. Foi para Rondônia, mas acabou voltando para Foz do Iguaçu. Montou um comércio no bairro Morumbi, Região do Rincão São Francisco, onde mora há, praticamente, 30 anos. Entrevista realizada em 26 de janeiro de 2007, no bairro Morumbi, na região São Francisco, na cidade de Foz do Iguaçu.

Carlos, casado, 61 anos, nasceu em 1946, na cidade de Foz do Iguaçu (PR). Começou a trabalhar cedo, vendendo verduras. O primeiro emprego foi numa serraria. Em seguida, firmou-se na construção civil, atuando ora como pedreiro, ora como armador de ferragem. Trabalhou por cinco anos, como pedreiro, na construção da usina de Itaipu, e, posteriormente, como montador, na construção da estação de Furnas. Atualmente, continua trabalhando como pedreiro, na construção

\footnotetext{
* Os trabalhadores citados autorizaram a utilização de seus depoimentos, neste estudo. Três deles, entretanto, não assinaram o termo de autorização. Por isso, estão apresentados com nomes fictícios e sem dados de identificação.
} 
civil. O senhor Carlos mora em sua pequena chácara, herdada de seu pai, na região próxima ao cemitério Parque do Iguaçu. Entrevista realizada em 27 de março de 2007, Região Jardim São Paulo, na cidade de Foz do Iguaçu.

Crispina, casada, 68 anos, aposentada; nasceu em Foz do Iguaçu, em 1939. Começou a trabalhar cedo, juntamente com seu pai, um pequeno agricultor que vivia de vários expedientes. Mora, desde que nasceu, na porção sul do município, às margens do rio Iguaçu, na região do Porto Meira. Desde os 12 anos de idade, dona Crispina exerceu atividade no comércio fronteiriço com a Argentina: ela vendia laranjas, em Puerto Iguazu, e comprava produtos alimentícios industrializados, para revender em Foz do Iguaçu. Ao lado desta atividade, trabalhou, quase toda a vida, como lavadeira, e, também, por dois anos, em uma madeireira. Entrevista realizada em 26 de março de 2007, no bairro Jardim Oriente, Região Porto Meira, na cidade de Foz do Iguaçu.

Ernestina, 60 anos, nasceu em 1947, na cidade de Assunción (PY). Mora em Foz do Iguaçu, desde 1976. Veio para a cidade com a expectativa de trabalhar como secretária tradutora, na Empresa Binacional Itaipu, uma vez que tinha domínio do inglês e do alemão, além de sua língua materna - o espanhol. Mas a oferta de trabalho veio do setor hoteleiro. Começou trabalhando na recepção do Hotel Carimã. Desde então, alternou várias funções, no setor turístico - secretária, operadora de locadora de veículos, guia de agências ou de hotéis. Atualmente, trabalha como guia. Entrevista realizada em 22 de março de 2007, no bairro Jardim Alice II, Região Jardim São Paulo, na cidade de Foz do Iguaçu.

Erasmo, casado, 61 anos, nasceu em 1946. No início da década de 1960, o senhor Erasmo e família adquiriram terras no Paraguai. Devido ao insucesso desta empreitada, ele, seus pais e irmão voltaram para o Brasil e se fixaram em Foz do Iguaçu, onde passaram a trabalhar como agregados, nas propriedades rurais localizadas na região norte do município de Foz do Iguaçu. O senhor Erasmo trabalhou, na limpeza de lavouras, como carpidor, e, na abertura de terrenos para agricultura, fazendo destoca. Aprendeu a ser operador de máquinas e passou a trabalhar com terraplanagem. Atualmente, é proprietário de um pequeno caminhão, que ele usa para fazer serviços de mudança. Desde que mudou-se para Foz do Iguaçu, o senhor Erasmo mora na região norte do município. Entrevista realizada em 9 de janeiro de 2007, no bairro Jardim Bandeirantes, Região Três Lagoas, na cidade de Foz do Iguaçu. 
Eufrásio, casado, 77 anos, aposentado; nasceu em 1930, na cidade de Coronel Ouviedo (PY). Veio para Foz do Iguaçu com sua esposa, em 1956. Trabalhou para a Industrial Madeireira, por quase 10 anos: depois, na madeireira São Cristóvão. Com o fim das madeireiras, passou a trabalhar como pedreiro, profissão esta que ocupou até se aposentar. Desde que chegou a Foz do Iguaçu, mora na porção oeste da cidade, na Região do Jardim América. Até 1966, morou na vila montada pela madeireira, próxima às margens do rio Paraná. A partir dessa data, passou a residir na Vila Paraguaia, onde comprou um terreno e construiu a casa onde vive até hoje. Entrevista realizada em 26 de janeiro de 2007, no bairro Vila Paraguaia, Região Jardim América, na cidade de Foz do Iguaçu.

Eugênia, viúva, 68 anos, aposentada; nasceu em 1939, na cidade de Foz do Iguaçu (PR). Ao longo de sua vida na cidade, trabalhou como babá, lavadeira e camareira, até empregar-se no Colégio Agrícola, onde trabalhou como zeladora, até aposentarse. Entrevista realizada em 29 de janeiro de 2008, no Loteamento Nossa Senhora da Luz, Região Porto Meira, na cidade de Foz do Iguaçu.

Francisca, viúva, 81 anos, aposentada; nasceu em Foz do Iguaçu, em 1927. Ao lado do marido, morou e trabalhou, por 10 anos, no Boicy, próximo à atual região central da cidade. Seu marido puxava carga do porto oficial, e ela cuidava da casa, dos filhos e da criação. Ao final desse período, eles venderam a casa e compraram uma chácara, próxima ao Parque Nacional, na região rural sul de Foz do Iguaçu, onde viveram cerca de 30 anos. Depois, voltaram a morar na cidade, mais precisamente, no bairro Vila Yolanda. Entrevista realizada em 31 de janeiro de 2008, no bairro Vila Yolanda, região Centro, na cidade de Foz do Iguaçu.

Geralda [nome fictício]. Entrevista realizada em 23 de março de 2007, no centro da cidade de Foz do Iguaçu.

Guilherme, viúvo, 83 anos, aposentado; nasceu no ano de 1924, em Guaranésia, no estado de Minas. Veio para Foz do Iguaçu, em 1940, junto com seu pai, contratados pela empresa Dolabela, responsável por um conjunto de obras a serem realizadas no Parque Nacional, fundado em 1939. O senhor Guilherme era canteiro e trabalhou na construção do Hotel das Cataratas, da estrada das cataratas, da usina São João e do prédio Gresfi. Quando o trabalho de obras foi concluído, foi contratado pelo Hotel das Cataratas, para fazer o trabalho de manutenção elétrica, e aí trabalhou, até se aposentar. Entrevista realizada em 23 de março de 2007, na vila $\mathrm{B}$, região AKLP, na cidade de Foz do Iguaçu. 
Guilhermina, 68 anos, nasceu em Foz do Iguaçu, no ano de 1939. Desde criança, trabalhou na roça, com os pais, no Carimã, região sul da cidade. Já casada e com filhos, trabalhou como professora, no Colégio Mitre. Em função dos problemas de saúde de um de seus filhos, deixou o trabalho na escola e passou a viver e trabalhar na chácara onde seu marido trabalhava, localizada na região rural norte do município. Entrevista realizada em 26 de março de 2007, no bairro Vila Yolanda, Região Centro, na cidade de Foz do Iguaçu.

Irmã, viúva, 68 anos, aposentada; nasceu em Hernandárias (PY). Chegou a Foz do Iguaçu, em 1960. Ela e o marido fugiam da perseguição política empreendida pelo governo ditatorial de Stroessner. Ambos trabalharam em uma madeireira, localizada no Porto Belo, até o final da década de 1960. Dona Irmã cozinhava para outros operários solteiros da madeireira. Com a falência desta última, passou a dedicar-se ao trabalho no lar, e seu marido passou a trabalhar como vigilante, até se aposentar. A senhora Irmã mora na Vila Paraguaia, onde ela e o marido construíram sua casa, ainda na época em que trabalhavam na madeireira. Ao longo de todos esse anos, ela viveu na região do Jardim América. Entrevista realizada em 25 de janeiro de 2007, no bairro Vila Paraguaia, Região Jardim América, na cidade de Foz do Iguaçu.

João S, casado, 66 anos, aposentado; nasceu em Foz do Iguaçu, em 1941. Aos 13 anos de idade, deixou a chácara onde vivia com seus pais e começou a trabalhar em madeireiras, atividade que exerceu por, aproximadamente, 21 anos. Com o fechamento das madeireiras, passou a trabalhar como vigilante. O senhor João nasceu no Porto Meira e, depois que começou a trabalhar, passou a morar nas vilas das madeireiras, às margens dos rios Iguaçu e Paraná. Quando as madeireiras fecharam, ele continuou morando na região do Jardim América, até 1997, quando comprou uma casa na Vila C, onde vive atualmente. Entrevista realizada em 11 de janeiro de 2007, na Vila C, na cidade de Foz do Iguaçu.

João F, viúvo, 89 anos; nasceu em 1918. Mudou-se com sua família para Foz do Iguaçu, em 1970, onde comprou um lote de terra, na região do São Francisco. Nesta região da cidade, o senhor João viveu como agricultor e, depois, como pequeno comerciante. Atualmente, mora no bairro Morumbi. Entrevista realizada em 23 de março de 2007, no bairro Morumbi, Região do Rincão São Francisco na cidade de Foz do Iguaçu. 
João C, 76 anos, casado com dona Zeni, aposentado. Até mudar-se para Foz do Iguaçu, em 1958, trabalhava no campo, na região Guaraniaçu (PR). Em Foz do Iguaçu, começou na usina de energia elétrica e, depois, trabalhou no Colégio Agrícola, até se aposentar. Morou sempre perto do trabalho: primeiro na região do centro, próxima à usina; depois, no Porto Meira, perto do Colégio Agrícola. Entrevista realizada no bairro Jardim Eliza na Região Porto Meira em Foz do Iguaçu de 30 de janeiro de 2008.

Joaquim [nome fictício]. Entrevista realizada no bairro Jardim das Flores, em 9 de janeiro de 2007.

Joel [nome fictício]. Entrevista realizada no centro da cidade de Foz do Iguaçu, em 29 de Janeiro de 2008.

Luís C, casado, 58 anos. Chegou a Foz do Iguaçu, em 1970. Trabalha como guia turístico, desde então. Morou sempre no centro da cidade. Entrevista realizada em 24 de março de 2007.

Luís T, casado, 62 anos, aposentado; nasceu em Guarapuava (PR), no ano de 1942. Veio para Foz do Iguaçu, em 1945, com sua família. Ao longo de sua vida, exerceu diversas ocupações: foi professor, motorista, trabalhou na construção civil, mas se reconhece, fundamentalmente, como agricultor. Desde que chegou a Foz, morou sempre na área rural sul da cidade. Entrevista realizada no Carimã, na cidade de Foz do Iguaçu, em 12 de janeiro de 2007.

Marcelino, casado, 67 anos, aposentado; nasceu em Isapucu (PY). Chegou em Foz do Iguaçu, em 1960, atraído pela possibilidade de trabalhar na construção da ponte da Amizade. Depois de trabalhar como carpinteiro, na construção da ponte, foi para São Paulo, junto com a empresa que o contratara para trabalhar na construção de um viaduto. Terminada a obra, voltou para Foz do Iguaçu e continuou trabalhando como carpinteiro. Aposentou-se e montou um pequeno comércio, na vila Paraguaia, bairro em morou, desde que chegou à cidade. Entrevista realizada no bairro Vila Paraguaia, na cidade de Foz do Iguaçu, em 25 de janeiro de 2007.

Margarida, viúva, 63 anos, aposentada; nasceu em 1944, na cidade de Montes Claros (MG). Mudou-se, com a família, para Foz do Iguaçu, em 1971. Antes disso, morou no estado de São Paulo e, depois, em Ubiratã (PR) e, mais tarde, em Goioerê (PR). Quando chegou em Foz do Iguaçu, ela e sua família trabalharam, durante seis anos, no cultivo de hortelã e soja, na região do São Francisco. A partir 
de 1976, foi morar na cidade e trabalhou como faxineira, até aposentar-se. Morou, por quatro anos, na favela Monsenhor Guilherme, até conseguir comprar um terreno, num um grande loteamento, criado no final da década de 1970, na região do São Francisco. Entrevista realizada no bairro Morumbi, na cidade de Foz do Iguaçu em 22 de março de 2007.

Militona, viúva, 71 anos, aposentada; nasceu em 1936, em Santa Helena, distrito de Foz do Iguaçu. Em 1953, após o casamento, mudou-se com o marido para Foz do Iguaçu. Ela e o marido tinham uma chácara, na região do Porto Meira. Ao longo de sua vida na cidade, ela trabalhou numa fábrica de tijolos, depois disto, trabalhou com revenda de mercadorias compradas na Argentina e como auxiliar de serviços gerais, em Hotéis da cidade. Entrevista realizada no bairro Jardim Oriente, Região Porto Meira na cidade de Foz do Iguaçu, em 27 de março de 2007.

Perciliana, casada, 52 anos; nasceu em Manhuaçu (MG), em 1955. Sua família mudou-se para Foz do Iguaçu, em 1966, e instalou-se no distrito de Santa Terezinha. Até meados da década de 1970, dona Perciliana trabalhou na roça. Com a construção da Usina, passou a trabalhar como empregada doméstica e mudou-se para Foz do Iguaçu, onde fixou residência, na região de Três Lagoas. Entrevista realizada no bairro Jardim Bandeirante, Região Três Lagoas na cidade de Foz do Iguaçu, em 11 de janeiro de 2007.

Zeni, casada com Sr. João C, 68 anos, do lar, nasceu em Guaraniaçu (PR). Era agricultora, até mudar-se para Foz do Iguaçu com seu marido. Entrevista realizada no bairro Jardim Eliza, Região Porto Meira na cidade de Foz do Iguaçu, em 30 de janeiro de 2008.

A partir do diálogo com a banca de qualificação, percebi a necessidade de incorporar novas questões à problemática da pesquisa. Tratava-se de analisar a influência do exército na história da cidade. Afinal, o recorte temporal deste estudo abrangia o período do governo militar (1964-1985) que, por sua vez, foi responsável pela construção da usina hidrelétrica de Itaipu, na cidade de Foz do Iguaçu, num processo marcado por muitos conflitos. Além disso, a ligação de Foz do Iguaçu com o exército parece ter atravessado a história da cidade, desde sua fundação. Em 1889, por determinação do Ministério da Guerra, foi fundada a Colônia Militar, 
no ângulo formado entre os rios Iguaçu e Paraná. Em 1910, a Colônia Militar foi extinta, e foi criado, na sua antiga sede, o distrito denominado Iguaçu, sob a jurisdição do município de Guarapuava. A fundação da Colônia Militar, em 1889, e a criação e instalação da $1^{\text {a }}$ Companhia Independente de Fronteira do Exército, em 1932, são lembradas como marcos de progresso, nos livros de história da cidade. Na perspectiva apresentada nestes livros, a ação do Exército, na cidade, respondia aos interesses nacionais de defesa do território brasileiro, por meio da ocupação da tríplice fronteira oeste, do Brasil com Argentina e Paraguai.

\section{Localização do município de Foz do Iguaçu}

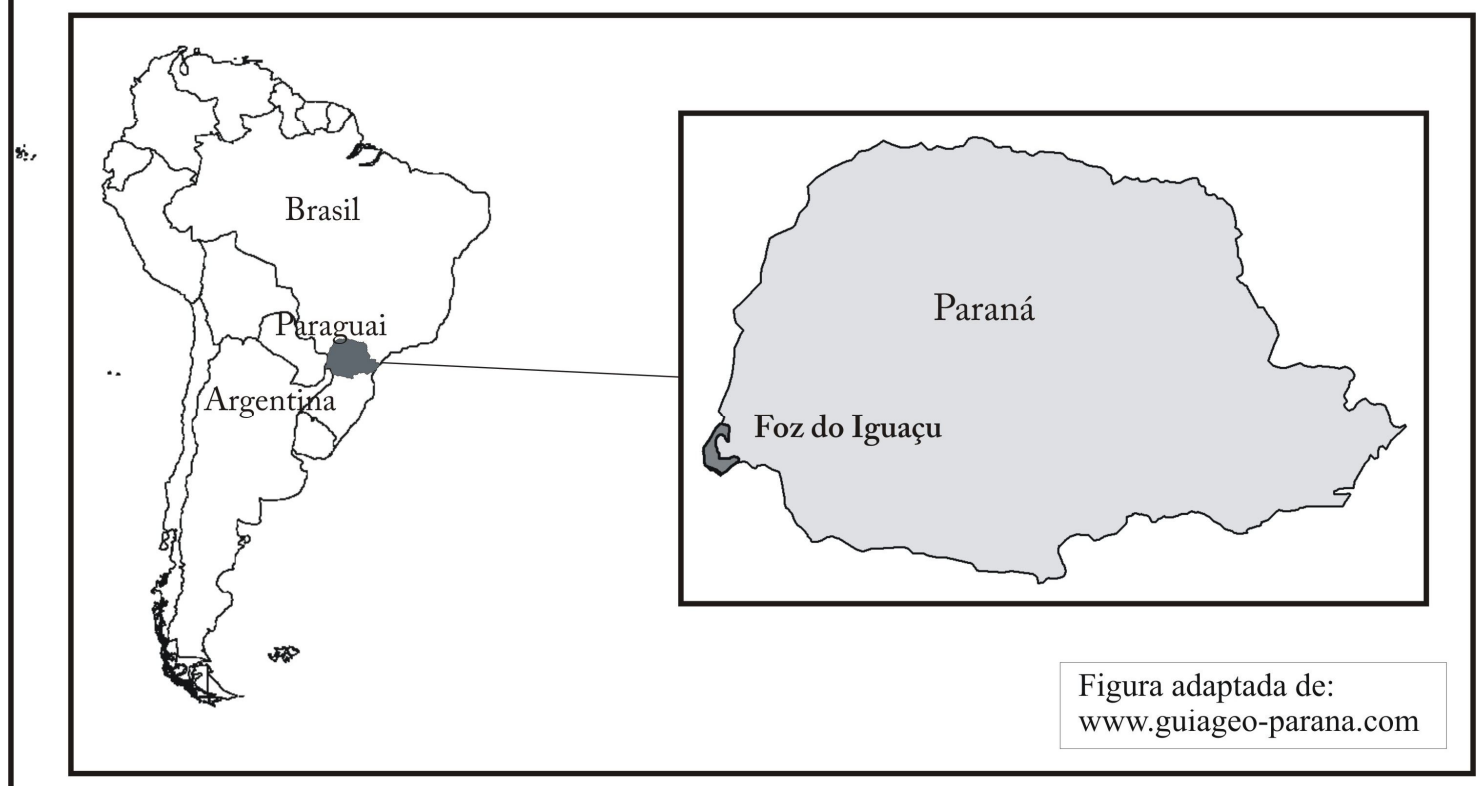

Org. E Conf. TIZ, G. J., 2009

MAPA 3. Localização do Município de F oz do Iguaçu

Nos relatos dos trabalhadores entrevistados, o exército significou, até meados da década de 1970, um dos maiores consumidores da produção agrícola dos colonos. Mas, contraditoriamente, foi identificado, também, como principal agente repressor das estratégias 
de sobrevivências desenvolvidas por esses trabalhadores, quando estas incluíam o comércio de mercadorias nas fronteiras com Argentina e Paraguai.

Nesse sentido, avaliei que uma análise dos aspectos conflituosos das relações entre o Exército e os moradores da cidade avançava, ainda mais, na problematização da memória homogeneizadora de Foz do Iguaçu, como cidade turística construída a partir da década de 1970. Para desenvolver esta pesquisa, insisti, ao longo do ano de 2008 , na busca de relatórios oficiais que informassem séries históricas sobre a prática de contrabando, na cidade de Foz do Iguaçu, mas não tive sucesso. Os comandos tanto do $34^{\circ}$ Batalhão do Exército quanto da Capitania dos Portos, em Foz do Iguaçu, não possuem arquivos próprios, o que me levou a buscar tais informações no Arquivo Histórico do Exército, na Biblioteca do Itamaraty e no Arquivo Nacional, todos estes localizados na cidade do Rio de Janeiro. No Arquivo Histórico do Exército, de toda a documentação desejada, encontrei apenas Relatórios da Colônia Militar de Foz do Iguaçu (1889-1910).

A pesquisa na Biblioteca do Itamaraty e no Arquivo Nacional foi, sucessivamente, adiada, ao longo do ano de 2008, em função de questões técnicas destes órgãos. A Biblioteca do Itamaraty permaneceu fechada para pesquisa, em razão dos trabalhos de higienização de seu acervo que, até setembro de 2008, não tinham sido concluídos. No Arquivo Nacional, a sorte não foi melhor. A documentação sobre a faixa de fronteira estava indisponível, inclusive para reprodução, por motivo de uma reforma no sistema de ar refrigerado, inconclusa até setembro de 2008. Todos esses contratempos me obrigaram a abandonar a proposta de incorporar a discussão sobre as dimensões conflituosas da relação histórica entre o Exército e a cidade de Foz do Iguaçu.

Diante disso, concentrei todos os esforços na análise das fontes encontradas nas Bibliotecas de Foz do Iguaçu e das entrevistas realizadas com os trabalhadores, entre os anos 
de 2007 e 2008. Essas análises continuaram sendo orientadas pela perspectiva crítica de problematizar a construção de uma memória da cidade que reduzia sua história à evolução do turismo nas Cataratas.

O resultado de todo esse esforço está estruturado em quatro capítulos.

No Capítulo 1, apresento um balanço crítico da historiografia sobre a cidade de Foz do Iguaçu. Selecionei os estudos realizados a partir da década de 1980, pois, antes desse período, tudo o que tinha sido produzido sobre a história da cidade estava disperso em relatos de viajantes. O objetivo é analisar o conteúdo dessa literatura, à luz do contexto em que foi produzida, identificando suas contribuições e limites, de maneira a definir Foz do Iguaçu como objeto de investigação histórica.

No segundo capítulo, analiso o processo de produção da memória única que tentou reduzir o passado da cidade à história de sua vocação turística. No texto, procuro expor as contradições que permeiam o discurso ideológico característico dessa memória. Sobre isso, indaguei sobre o efeito dessa memória sobre trabalhadores entrevistados, cujo perfil definiuse por sua presença, desde a década de 1960. Isto foi feito, porque tornou-se recorrente, nas entrevistas, referências à vocação turística de Foz do Iguaçu. Assim, estruturei o Capítulo 3 em torno da análise de como se deu a relação entre os trabalhadores e a memória oficial que vinculou a cidade de Foz do Iguaçu à cidade turística. Sobretudo, tento explorar as tensões, registradas nas entrevistas, que questionam o modo como essa memória foi estruturada, bem como seus marcos e protagonistas. De modo geral, enfatizo a forma com que estes trabalhadores reivindicam tal memória para si.

No quarto e último capítulo, analiso os relatos dos trabalhadores sobre seus modos de vida e trabalho, com o objetivo de alcançar suas formulações sobre o passado da cidade. 
Procuro discutir a autonomia relativa que os trabalhadores demonstram na estruturação de sua própria memória da cidade, salientando suas experiências e percepções sobre as dinâmicas econômicas constitutivas da cidade de Foz do Iguaçu. 


\section{CAPÍTULO 1.}

\section{0 tema e o objeto na historiografia: a cidade de $\mathrm{F}$ oz do I guaçu.}

Neste capítulo apresento um balanço crítico da historiografia sobre a cidade de Foz do Iguaçu. O objetivo é analisar o conteúdo dessa produção, à luz do contexto em que foi produzida, identificando suas contribuições e limites, de maneira a definir Foz do Iguaçu como objeto de investigação histórica.

Até a publicação de Obrageros, Mensus e Colonos: história do Oeste Paranaense, por Ruy Wachowicz, em 1982, tudo o que se sabia sobre Foz do Iguaçu derivava das descrições feitas por viajantes ${ }^{2}$. Esta publicação foi um dos resultados das propostas encaminhadas pelo subprojeto História da Área de Itaipu ${ }^{3}$. Tal projeto tinha como incumbência realizar um estudo na área que seria atingida pela barragem. Este estudo consistia no trabalho de levantar, arrolar e coletar as fontes históricas relacionadas ao período coletar as fontes históricas na área que seria atingida pela barragem no período compreendido entre 1853 e 1950. (WACHOWICZ, 1982, p.7).

\footnotetext{
${ }^{2}$ Essas obras foram escritas, em sua maioria, por militares e funcionários públicos, a partir do final do século XIX, quando foi fundada a Colônia Militar, próximo à foz do rio Iguaçu. ABREU, Antonio Cândido Ferreira de. A foz do Iguaçu: ligeira descrição de uma viagem feita de Guarapuava à Colônia do Iguaçu em novembro de 1892. Curitiba (PR), 1896. IDEM. Visita ao Salto de Santa Maria. Curitiba (PR), 1974. ASSIS, Dilermano. Nas barrancas do Alto Paraná. São Paulo (SP), 1926. BALLÃO, Jayme. A Foz do Iguaçu. Curitiba (PR), 1921. BRITO, José Maria de. Descoberta de Foz do Iguassú e fundação da Colônia Militar, Curitiba (PR), 1977. FIGUEIREDO, José de Lima. Oeste Paranaense. São Paulo (SP), 1937. FRANCO, A. MARTINS. Recordações de viagens ao alto Paraná. Curitiba (PR), 1973. MARTINEZ, César P. Sertões do Iguaçu. São Paulo (SP), 1925. NASCIMENTO, Domingos. Pela Fronteira: Paraná. Curitiba, 1903. NOGUEIRA, Júlio. Do rio Iguassú ao Guayra. Rio de Janeiro (RJ),1920. SILVEIRA NETTO, Manoel de A. Do Guaíra aos Saltos do Iguassú. Curitiba, 1914.

${ }^{3}$ O subprojeto História da Área de Itaipu foi implementado a partir de 14 de agosto de 1979, por meio do termo aditivo $\mathrm{n}^{\circ} 2$ ao Convênio $\mathrm{n}^{\circ} 081 / 75$, feito, no ano de 1975, entre a Itaipu e o Instituto do Patrimônio Histórico Nacional.
} 
A pesquisa realizada por Wachowicz (1982) foi, portanto, uma análise produzida à luz do processo de construção da hidrelétrica de Itaipu e das discussões acerca de seu impacto sobre as áreas urbanas e rurais que formavam, histórica, social e geograficamente, a área que seria atingida pela obra. Desse ponto de vista, as investigações desenvolvidas por esse pesquisador buscavam, também, produzir materiais para compor a memória de um lugar que sofreria drásticas e irreversíveis mudanças com a formação do lago da usina. Apesar disso, essa composição da memória foi, em grande medida, determinada pelos objetivos e pelos interesses relacionados à Itaipu que, por meio do subprojeto, direcionou a definição do objeto de estudo, as questões e o recorte histórico. Segundo nota do próprio autor, este subprojeto estabelecia a necessidade de um estudo sobre a formação histórica da área que seria alagada com a construção da hidrelétrica. Além disso, o subprojeto História da Área de Itaipu estabeleceu um recorte temporal, que começava em 1853, ano da emancipação do Paraná, e encerrava-se no ano de 1950.

Assim, a leitura da narrativa histórica produzida por Wachowicz (1982) só pode ser entendida, plenamente, se for considerada como produto de um projeto de elaboração e produção de uma memória que se pretendia capaz de abarcar toda a região atingida pela construção da usina de Itaipu, a partir dos marcos estabelecidos por esta empresa. Pois, seguindo os parâmetros do subprojeto, pesquisador citado escreveu uma história da região do Oeste do Paraná circunscrita à área que seria atingida pela formação do lago da usina, entre o final do século XIX e o início dos anos de 1940, dentro do recorte histórico estabelecido pelo subprojeto.

Pode-se dizer que esse livro resulta de um estudo orientado por uma problemática regional e preocupou-se em explicar, sobretudo, como se deu o processo de ocupação, colonização, exploração e desenvolvimento da região do extremo oeste do Paraná, entre o final do século XIX e a primeira metade do século XX. Seu esforço em explicar a formação 
da região, a partir da determinação de suas origens, levou-o a iniciar um estudo também sobre a origem da cidade de Foz do Iguaçu, à medida que identificou, na fundação da Colônia Militar de Foz do Iguaçu, em 1889, os primeiros passos concretos do governo brasileiro na promoção da ocupação e do povoamento dessa região.

Embora a pesquisa desenvolvida por Wachowicz (1982) estivesse relacionada ao estudo da região atingida pela barragem da Itaipu, no lado brasileiro, o autor alargou este espaço, de maneira a definir uma nova delimitação para a pesquisa que passou a incorporar a porção ocidental da região do oeste paranaense. Essa porção é formada pelos municípios de Foz do Iguaçu, Guairá e Cascavel, Medianeira, Céu Azul, Matelândia, São Miguel do Iguaçu, Santa Helena, Toledo, Marechal Cândido Rondon, Terra Roxa, Nova Santa Rosa. Essa microregião, como o autor a chamou, não resultava apenas um recorte geográfico, mas era definida a partir de elementos de identificação e unidade histórica, social e econômica.

Trata-se de um sistema de exploração e predação das riquezas naturais, que foi implantado na região, desde as últimas décadas do século passado (século XIX) até, aproximadamente, a década de cinqüenta no século atual. É o sistema de obrages. (WACHOWICZ, 1982, p.11).

Assim, estabelecia-se, na obra de Wachowicz, a intersecção entre a história regional e a local, de modo que a história de Foz do Iguaçu constituía-se, também, na história da expansão e da colonização no extremo oeste do Paraná. Friso, contudo, que essas considerações iniciais não negam a importância da contribuição desse estudo para aqueles que buscam compreender e analisar os elementos que formaram a memória e a história da cidade de Foz do Iguaçu. A referida obra constituiu-se em referência importante, à medida que pode ser tomada com um dos primeiros esforços destinados a construir, por meio da pesquisa histórica, uma memória, não só para a região do oeste do Paraná, mas também para a cidade Foz do Iguaçu. 
Segundo Wachowicz (1982), essa história começou com os primeiros movimentos de ocupação e colonização da fronteira, a partir do final do século XIX, quando essa região era dominada pelo Sistema de Obrages ${ }^{4}$, ou seja, pelas empresas estrangeiras argentinas de exploração da erva-mate e madeira. Foi neste contexto que, próxima à foz do rio Iguaçu, ou, segundo José Maria de Brito, mais precisamente, "no ângulo formado pelos rios Iguassu e Paraná”, foi fundada a Colônia Militar. Nela, Wachowicz reconheceu a origem, o núcleo fundador da cidade de Foz do Iguaçu. Assim, a história da cidade de Foz do Iguaçu, uma vez introduzida na narrativa, a partir da história de seu núcleo fundador, não recebeu de Wachowicz o tratamento usual da história política, de modo que não foi possível encontrar, em seu texto, as diferentes fases que contam seu processo emancipatório, de colônia militar para vila e de vila a município. Importou muito mais, para o autor em tela, entender qual foi e como foi o processo social e econômico que produziu a cidade.

A narrativa desenvolvida por Wachowicz (1982) definiu a cidade, inicialmente, como produto natural de sua localização geográfica, à medida que seu núcleo fundador foi a Colônia Militar, instalada na margem direita do rio Paraná, quando este se encontra com o rio Iguaçu, ambos considerados fronteiras naturais entre o Brasil, Argentina e Paraguai. A formação da cidade de Foz do Iguaçu constituía-se, portanto, na consolidação de um limite político e social entre os territórios do Brasil, da Argentina e do Paraguai.

Ao mesmo tempo, a cidade resultava de uma função primeira, que a definiu antes mesmo dela existir, pois sua formação foi, segundo Wachowicz (1982), uma iniciativa do governo brasileiro para retomar o controle do território nacional, até então dominado por

\footnotetext{
${ }^{4}$ A chamada obrages foi uma propriedade e/ou exploração típica das regiões cobertas de matas subtropicais, em território argentino ou paraguaio. $O$ interesse fundamental de um obragero não era a colonização em regime de pequena e média propriedade, nem povoamento de suas vastas terras. Seu objetivo precípuo era a extração de erva mate, nativa da região, bem como da madeira em toros, abundante na mata nativa, subtropical. [...] Como o controle geo-econômico da navegação do sistema do Prata pertencia à Argentina, foram os obrageros desta nação os principais responsáveis pela introdução desse sistema em território brasileiro, ou mais especificamente: paranaense e mato-grossense." (WACHOWICZ, 1982, p.44). Além disso, cumpre destacar a presença de capital inglês, associado ao capital argentino.
} 
argentinos e paraguaios. Em resumo, nascida a partir de uma Colônia Militar, a cidade de Foz do Iguaçu teve como função precípua consolidar os limites, fixar a fronteira e ampliar o domínio territorial brasileiro, na região oeste do país.

Para Wachowicz (1982) a fundação da Colônia Militar e, deste modo, o processo de formação da cidade, foi um passo na direção de incorporar e envolver a região do extremo oeste nas malhas do desenvolvimento econômico brasileiro. Talvez, por estar convicto de que Foz do Iguaçu tivesse este papel, aquele autor tenha produzido uma história da cidade como a história de sua função. Em Obrageros, mensus e colonos, a história de Foz do Iguaçu ganhou os contornos da história de seu papel na integração e na civilização do oeste.

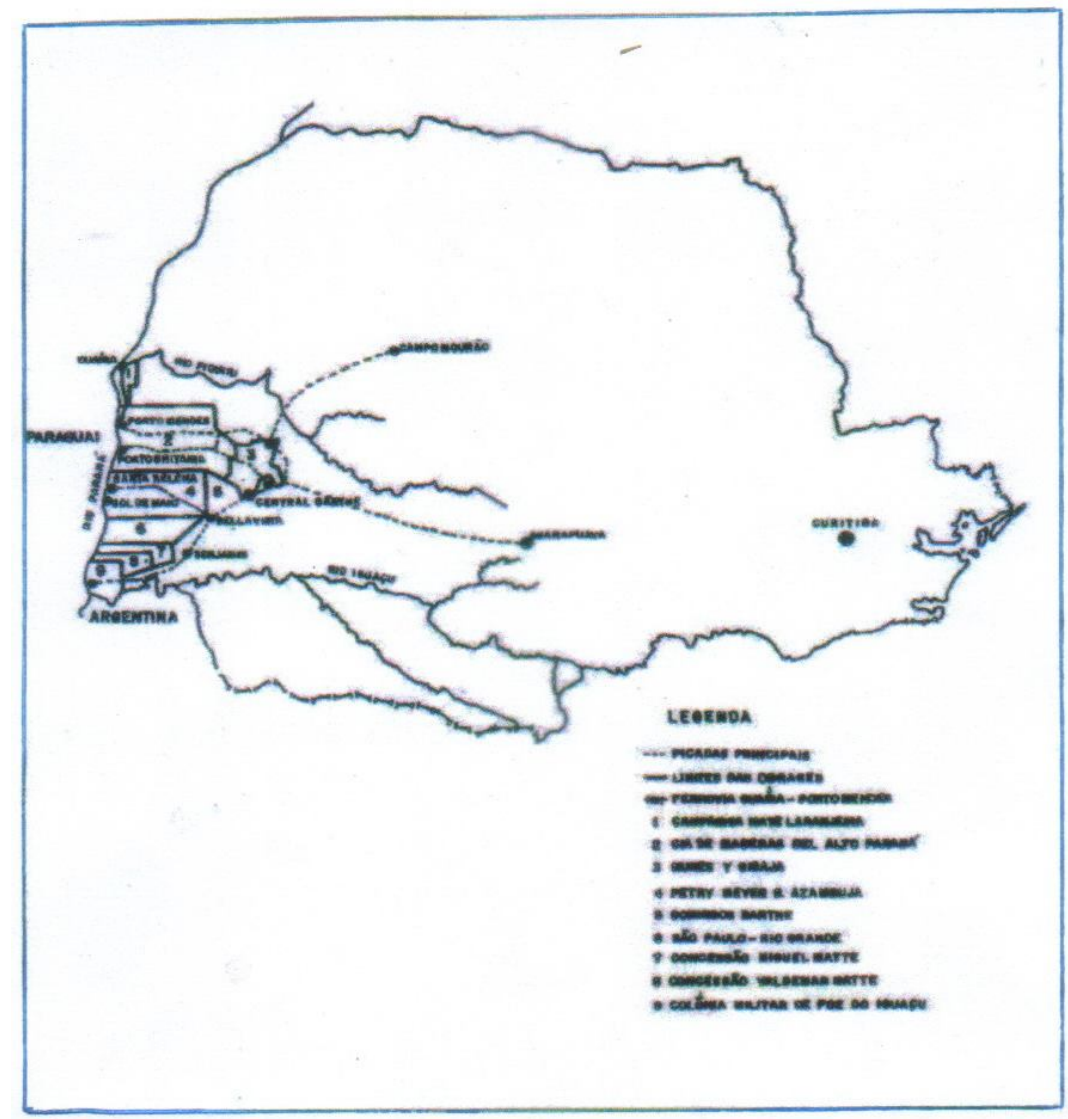

MAPA 4. Principais obrages no Oeste do Paraná. Fonte: COLODEL. Obrageros \& companhias colonizadoras (p.56). 
Assim, pelas análises de Wachowicz (1982), Foz do Iguaçu nasceu como ponto estratégico para proteger as fronteiras do país contra a presença de 'vanguardas' das frentes argentinas e (ou) paraguaias de extração de mate e madeira, que invadiam o território brasileiro, por meio do sistema de obrages. Segundo o autor, a instalação da Colônia Militar, montada pelo Ministério da Guerra, desde o início, organizou o processo de defesa da fronteira, por meio do povoamento que foi realizado a partir da distribuição gratuita de terras da colônia para o desenvolvimento da atividade agrícola. Contudo, ainda conforme o mesmo pesquisador, este processo caminhava a passos lentos:

Em 1905, a população civil, no território da colônia, era de aproximadamente mil habitantes. A grande maioria continuava sendo formada de trabalhadores braçais, de origem paraguaia (guarani) e argentina. Cândido de Abreu informa que, nesta data, a população propriamente colonial era composta por 58 famílias, que ocupavam os lotes distribuídos gratuitamente pela direção da colônia. Desses 58 colonos 33 eram estrangeiros, 5 solteiros e incapazes para o trabalho e o restante, 20, eram brasileiros [...] (WACHOWICZ, 1982, p.24).

Seguindo esse raciocínio, Foz do Iguaçu teria a função não apenas de proteção militar da fronteira, mas, fundamentalmente, de integração daquela região ao território e à nação brasileiros, a partir da um núcleo populacional disposto a desenvolver uma economia de base agrícola, capaz de fixar os colonos brasileiros naquela fronteira. De acordo com Wachowicz (1982, p.24), “A finalidade primordial da fixação de colonos na colônia militar, era estimular o povoamento por brasileiros e proporcionar a produção de gêneros alimentícios". Tratava-se, portanto, de um processo civilizatório que implicava a mudança nas formas predominantes de organização da economia e do trabalho na região até então ligados à exploração da madeira e do mate. Sobre isso, o mencionado autor avaliava que "A presença da colônia militar e de sua respectiva população agrícola, visava alterar os costumes exploratórios de predação, utilizados no mate e na madeira." (WACHOWICZ, 1982, p.25). 
Mas Wachowicz logo percebeu as dificuldades de que esse projeto alcançasse seu objetivo de proteger a fronteira contra a influência estrangeira. Apoiado nas observações do engenheiro Cândido de Abreu, concluiu que os colonos brasileiros não praticavam a agricultura e seguiam dedicando-se às atividades que abasteciam a economia argentina com a exploração e venda de erva-mate e madeira. Tal comportamento resultava, na visão do autor, do comportamento corrupto que prevaleceu na colônia militar. Wachowicz (1982) acusou claramente as autoridades militares da Colônia de terem sido incorporadas pela prática do contrabando de exportação e importação. Em parte, ele considerou este comportamento explicável, pois, a colônia militar de Foz do Iguaçu estava localizada na fronteira, considerada, pelo autor, um lugar natural de desterro e exílio. Dessa condição desdobrou a conclusão de que o exército designava, para a Colônia de Foz do Iguaçu, militares com comportamento desviante e de má índole. Todos os que aportavam em Foz do Iguaçu, segundo Wachowicz, já traziam em si o traço da corrupção e do desvio, como sugeriu neste comentário:

Os diretores e oficiais que para ali eram destacados, na realidade o faziam para penitenciarem-se de delitos políticos cometidos contra o governo federal. Sendo assim, uma vez no desterro de Foz do Iguaçu, não possuíam outro objetivo do que o pensamento premeditado de fazer fortuna em pouco tempo ou mesmo para dirimir situações financeiras difíceis. Este posicionamento atingia os subalternos. $\mathrm{O}$ alferes farmacêutico negociava madeira, o alferes secretário, com fazendas em sociedade com outros, o diretor interino negociava com os próprios colonos [...] (WACHOWICZ, 1982, p.25).

Porém, esses argumentos reproduziram uma visão preconceituosa, presente nos discursos de Cândido de Abreu, uma das fontes mais citadas por Wachowicz quando se tratou de caracterizar a situação da Colônia Militar. Sua argumentação seguiu um raciocínio mecânico de causa e efeito em que, estando a colônia militar localizada na fronteira, que é por sua vez um lugar de desterro, resultava, então, que todos os membros dessa colônia seriam 
corruptos e corruptíveis. Ainda que fosse verdadeira a afirmação de que a maioria dos oficiais enviados para a Colônia Militar estivesse sendo punida por isso, caberia indagar sobre a natureza das tais infrações cometidas para saber se havia relação destas com as práticas de contrabando. Ao contrário disso, Wachowicz (1982) aceitou-as como provas de uma predisposição herdada à prática criminosa de acúmulo ilícito de riqueza e que, em última instância, contribuíram para o fracasso do projeto da Colônia Militar. Esta interpretação, que associou à fronteira e àqueles que nela viviam o traço da ilegalidade, foi muito utilizada, por outros estudos, nas explicações históricas e sociológicas sobre as características da cidade de Foz do Iguaçu e, por isso também, contribuiu para construir um mito de que a ilegalidade é uma característica intrínseca à vida na fronteira.

Outro grande fator, destacado por Wachowicz na tentativa de explicar o fracasso inicial da Colônia Militar na defesa das fronteiras ocidentais, por meio do povoamento baseado na pequena propriedade agrícola, foi o que chamou abandono por parte das autoridades dos governos estadual e federal. Para Wachowicz (1982), o governo federal abandonou a colônia, pois não investiu na manutenção dos prédios públicos, não investiu em equipamentos urbanos e nem mesmo na construção de um porto. Diz ele: "Em 1919, as ruas não eram alinhadas, não havia calçamento, nem iluminação pública. As construções eram quase todas de madeira e cobertas de zinco" (p. 38). Carente de equipamentos públicos, de médicos, de funcionários públicos, a cidade agonizava, abandonada à sua própria sorte. $\mathrm{O}$ autor prossegue: "Enquanto a população de Foz do Iguaçu trabalhava e fazia quarto a defunto, o governo federal deixava a cidade no mais completo abandono" (p.40). Além disso, o governo federal oferecia remunerações tão baixas que inviabilizavam o próprio funcionamento das repartições públicas, pois era difícil encontrar quem se dispusesse trabalhar por tão pouco. Segundo dados coletados por Wachowicz (1982), o custo de vida em Foz do Iguaçu era bastante alto, “[...] custando o quilo do feijão $1 \$ 200$, o arroz de qualidade 
inferior $2 \$ 000$ e o pão 1\$500”. (p.41). O insucesso da colônia foi, neste sentido, resultado, também, da omissão do governo federal, que não criou as condições materiais e humanas para que se processasse a defesa do território contra os interesses estrangeiros.

As medidas tomadas pelo Estado Brasileiro, ou pelo próprio governo paranaense, a fim de fazer sentir, na região das barrancas do Paraná a presença da autoridade brasileira, eram tímidas e não atingiam seus fins. Uma mesa de rendas, coletoria, prefeitura, algumas dezenas de policiais, não resolviam o problema. [...]. (WACHOWICZ, 1982, p.128).

No entender de Wachowicz, esse abandono estava evidenciado, também, na falta de meios e vias de comunicação e transportes eficientes que permitiriam aproximação e integração maiores de Foz do Iguaçu com o restante do território brasileiro. O isolamento da cidade em relação a este último aproximava Foz do Iguaçu da Argentina, o que, além de garantir os melhores caminhos pela via fluvial, oferecia a Foz até mesmo seu sistema de correio.

\begin{abstract}
Nas primeiras décadas após sua fundação, Foz do Iguaçu estava como que de costas para o restante do Brasil. A não ser a péssima picada para Guarapuava, toda a comunicação estava voltada ao rio Paraná e consequentemente para o Prata. Para o norte, os saltos das Sete Quedas impediam a navegação com o Estado de São Paulo. Para Curitiba existia apenas uma difícil comunicação via Guarapuava, que em tempos de chuva ficava intransitável. Foz do Iguaçu comunicava com o mundo a jusante, pelo rio Paraná. Quando dos primeiros anos de sua fundação o melhor meio de chegar à região, era via Buenos Aires. (WACHOWICZ, 1982, p.28).
\end{abstract}

Na opinião de Wachowicz (1982), esse ambiente de abandono e isolamento de Foz do Iguaçu favorecia enormemente a presença e a influência dos argentinos nas atividades econômicas. De um lado, os argentinos faziam prevalecer seus interesses, quando conseguiam comprar grandes lotes de terra para garantir a exploração e a exportação do mate e da madeira, mobilizando a maior parte dos colonos no trabalho das obrages e impedindo, assim, 
o desenvolvimento da pequena propriedade agrícola, na colônia de Foz do Iguaçu. De outro lado, dominavam a economia desta cidade que estava alicerçada no contrabando.

O contrabando de madeira e de erva mate não foi, para Wachowicz, um problema exclusivo de Foz do Iguaçu, mas um drama que definia a vida econômica das regiões fronteiriças do sul do país até a região do Mato Grosso. Quando enumerou estes casos ao longo das fronteiras sul e sudoeste do Brasil, Wachowicz (1982) reafirmou sua teoria de que a vida das cidades de fronteira, especialmente a vida econômica, estava, também, implicada em atividades ilegais.

A população de Foz via-se na dependência das mercadorias trazidas pelos comerciantes argentinos, que vendiam bens de consumo como roupas, bebidas, alimentos e móveis, sem nenhuma fiscalização.

Toda a mercadoria consumida em Foz do Iguaçu, vinha da Argentina. Tudo entrava livremente, tanto alimentação, vestuário, móveis de casa, etc. [...] A população de Foz do Iguaçu só tinha contato com a civilização, quando chegava algum navio argentino. Quando um navio aportava, a população que podia, saía correndo em direção ao porto, era quase metade da população de Foz do Iguaçu. (WACHOWICZ, 1982, p.38).

Nos termos assim apresentados por Wachowicz, essas intensas relações comerciais fizeram de Foz do Iguaçu uma cidade platina em território brasileiro, pois a influência argentina não se resumia apenas à troca de mercadorias: “Em Foz do Iguaçu o português era falado apenas pelos funcionários públicos [...] Se as línguas mais utilizadas eram o espanhol e o guarani, o mesmo ocorria com o dinheiro circulante. O predomínio do Peso era absoluto." (WACHOWICZ, 1982, p.130). Ao final de suas argumentações, Wachowicz concluiu que a instalação da colônia não alterou em quase nada a influência estrangeira, principalmente a da Argentina, que manteve o controle das atividades comerciais na fronteira. 
Desde a chegada dos primeiros exploradores às barrancas do rio Paraná em fins do século passado (século XIX) o controle do comércio de toda a região caiu nas mãos das casas comerciais argentinas, existentes em Posadas ou Corrientes. O comércio do lado brasileiro passou a ser considerado uma simples extensão ou ampliação do desenvolvido pelos argentinos na região fronteiriça. Mesmo, após a instalação da Colônia Militar de Foz do Iguaçu, todo o abastecimento da região continuou sendo feito pela Argentina. [...]. Grande parte deste comércio de importação era feito por contrabando. Poucas eram as mercadorias que pagavam em Foz do Iguaçu, o imposto de importação. (WACHOWICZ, 1982, p. 131-132).

As conclusões de Wachowicz basearam-se no pressuposto frágil de que o conjunto das práticas econômicas, historicamente estabelecidas, na região, eram atrasadas, improdutivas e ilegais, e, por isso, eram inadequadas para o desenvolvimento de Foz do Iguaçu. Envolvido pelo discurso, principalmente do engenheiro Cândido Ferreira de Abreu, Wachowicz (1982) apenas repetiu seus argumentos, sem questionar suas intenções. Deste ponto de vista, talvez tenha-lhe faltado o distanciamento necessário para considerar a história daqueles que viviam e trabalhavam na região, antes que ela se tornasse objeto de intervenção do Estado, antes que o signo de fronteira se tornasse sua definição, a partir da instalação da Colônia Militar.

O modo como Wachowicz reproduziu essa percepção negativa da região Oeste do Paraná, da colônia militar e até mesmo de Foz do Iguaçu, não foi apenas resultado de uma relação pouco crítica com as fontes. Em certa medida, foi definida, também, por uma abordagem preocupada em estabelecer os marcos de ruptura com um determinado passado. Um passado dominado pela influência estrangeira. Por isso, a fundação da colônia, em 1889, se tornou um marco; porque foi a primeira tentativa de ruptura. No entanto, para Wachowicz (1982), essa ruptura só se consolidaria anos mais tarde, a partir da década de 1930, quando as obrages entraram em declínio e o governo federal criou um novo programa de ocupação e povoamento chamado 'Marcha para o Oeste' ${ }^{5}$. Desse modo, a década de 1930, foi, para o

\footnotetext{
${ }^{5}$ Marcha para o Oeste' foi uma designação criada, no contexto dos anos 30, para caracterizar os incentivos e as políticas adotadas pelo governo Vargas para promover a ocupação da fronteira oeste do Brasil.
} 
autor, um importante marco de ruptura em direção à integração do Oeste ao território nacional.

De modo geral, sua compreensão sobre o processo que engendrou as mudanças na fronteira foi a mesma quanto ao que levou ao surgimento da cidade de Foz do Iguaçu. Os fatos determinantes dessa transformação foram a crise do sistema de obrages e o programa de nacionalização da fronteira 'Marcha para o Oeste', organizado pelo governo federal.

Conforme Wachowicz (1982), foi, também, no contexto dos anos de 1930, que jornais começaram a noticiar projetos e propostas de desenvolvimento para Foz do Iguaçu, distantes das chamadas atividades ilegais de comércio de mate e madeira. Estes projetos apontavam o turismo como uma nova base econômica para a cidade.

Com o apoio da interventoria federal no Paraná, Ozório do Rosário Corrêa apresentou ao governo federal um plano que visava elevar Foz do Iguaçu a um centro turístico internacional. Expunha nesse plano, as origens das fontes financeiras para sua execução, propunha nacionalizar a região e transformar a prefeitura de Foz do Iguaçu em prefeitura especial, por dez anos. 'Tudo isso seria feito sem aqueles pruridos antipáticos de separação daquele território do todo paranaense'. Segundo esse plano, todas as arrecadações municipais, estaduais e federais do município, seriam aplicadas exclusivamente para o benefício do município. Os empréstimos seriam realizados pelo Banco do Brasil. Foz do Iguaçu seria transformada num centro de turismo internacional com cassinos, parques de diversão, navegação melhorada pelo rio Paraná. Uma rede de hotéis de linha internacional seria construída, com esses financiamentos. (WACHOWICZ, 1982, p.142).

Nessa direção, Wachowicz (1982) passou a tomar o turismo como grande possibilidade de desenvolvimento integrado da cidade de Foz do Iguaçu com o restante do país. O turismo foi apresentado como uma atividade econômica potencial, própria do lugar. Ao longo de suas argumentações, buscou produzir uma história do turismo na região, desde suas origens. 
Os pioneiros do turismo para a região foram a firma Nuñez y Gibaja e Vitória Aguirre. Em 1901, a firma referida iniciou na região das cataratas, do lado argentino, a exploração da madeira. Seus dirigentes, empolgados com a beleza que lhes proporcionava o rio Iguaçu, iniciaram uma propaganda dos saltos, na Europa. Assim sua beleza atravessou o Atlântico e foi atrais a primeira leva de turistas, que se constituiu o rastilho por onde se propagou a fama dos estupendos Saltos de Santa Maria.[...] Vitória Aguirre [...] construiu as suas custa um porto a margem esquerda do rio Iguaçu [...] para facilitar o desembarque dos turistas e ao mesmo tempo abriu a estrada que ligava o referido porto à região das Cataratas. Desde então, o fluxo turístico não mais parou. $\mathrm{O}$ número de turistas brasileiros era diminuto e mesmo assim, chegavam à região via Argentina. No início da década de 1920, já se falava em temporada de turismo às cataratas do Iguaçu. Os grandes obstáculos a um turismo brasileiro para a região, eram o isolamento de Foz do Iguaçu e as grandes distâncias a serem percorridas. Foi somente em 1915 que surgiu em Foz do Iguaçu o primeiro hotel, que levou o nome de Hotel Brasil, de propriedade de Frederico Engel. (WACHOWICZ, 1982, p.32-33).

Segundo Wachowicz, o ano de 1916 foi, também, um ano importante para a história do turismo, à medida que, pelo decreto $\mathrm{n}^{\circ} 653$, o Estado retomou a propriedade do lote outrora concedido, pelo Ministério da Guerra, ao argentino Jesus Val. Para Wachowicz (1982, p.37), esse decreto foi um importante passo na criação do futuro Parque Nacional do Iguaçu, pois tornava a área de 1008 hectares, localizada à margem direita do rio Iguaçu, junto às Cataratas de Santa Maria, em área de utilidade pública. Apesar de destacar a formulação do projeto de transformar Foz do Iguaçu num centro internacional de turismo, na década de 1930, Wachowicz insistiu na idéia de que muito pouco foi feito nesta direção. Nos anos que seguiram, a força dos interesses do governo federal jogou tais propósitos no esquecimento.

Em suas argumentações, Wachowicz (1982) se preocupou em convencer o leitor de que o turismo, nas Cataratas, era uma atividade econômica capaz, ao mesmo tempo, de emancipar Foz e região do domínio das obrages e de integrá-las ao território nacional e à economia brasileira. Ao mesmo tempo, tal integração promoveria a modernização da estrutura urbana adequada às necessidades decorrentes de um centro turístico. Mas essa modernização demoraria ainda para chegar a Foz do Iguaçu, apesar do sucesso da colonização do Oeste, organizada pelo governo federal, nos anos de 1930 e 1940. Isto porque, segundo Wachowicz, 
a ocupação planejada pelas colonizadoras conseguiu fixar o colono na região, embora tal fixação tenha garantido apenas a exploração econômica do território, segundo os interesses do Estado nacional e, principalmente, segundo os interesses particulares das colonizadoras e madeireiras do Rio Grande do Sul.

Nesse sentido, a obra de Wachowicz (1982) construiu 1930 como um marco histórico contraditório, que iniciou a nacionalização da fronteira e a consolidação do projeto colonizador brasileiro, mas que, ao mesmo tempo, representou, também, o marco do entrave do desenvolvimento econômico da cidade de Foz do Iguaçu. Desse modo, a política do governo federal, comandada pelos interesses das empresas de colonização gaúchas, no entender de Wachowicz, impediu a implantação de obras e ações capazes de promover a atividade turística, e, nesse sentido, o próprio desenvolvimento de Foz do Iguaçu.

Em Obrageros, mensus e colonos, a preocupação fundamental, seguindo os objetivos do subprojeto História da Área de Itaipu, foi constituir uma memória do passado da cidade. Em alguma medida, tratava-se, também, de transformar a cidade em passado da própria Itaipu. Para tanto, esse passado de Foz do Iguaçu tomou a forma de explicação originária para a futura construção da usina. As descrições produzidas por Wachowicz, na citada obra, terminaram por considerar que, até meados dos anos de 1940, as transformações econômicas que levariam Foz do Iguaçu ao desenvolvimento ainda estavam por vir. Assim, Foz se tornava, então, o ambiente natural e propício para a chegada do desenvolvimento, para a construção da Itaipu.

Enquanto as reflexões desenvolvidas por Wachowicz (1982) foram produzidas à luz do início da construção da Itaipu, os estudos realizados posteriormente, a partir da década de 1990, foram feitos num contexto de demissões em massa de operários da construção. O final do processo de construção da usina, certamente, impôs a necessidade de pensar o futuro da 
cidade, bem como o seu passado e as implicações nas dimensões econômicas e sociais de Foz do Iguaçu. Foi nessa direção que caminharam, também, as outras reflexões desenvolvidas pelos estudos sobre esta localidade, a partir nos anos de 1990. Nos estudos que se seguiram sobre Foz, as análises, assim como aquelas feitas por Wachowicz, continuaram sendo orientadas pela preocupação com o processo de desenvolvimento da cidade. Porém, as questões buscavam entender o significado do crescimento urbano e das mudanças na base econômica e social vividas desde o início da construção da usina hidrelétrica de Itaipu.

Em 1994, Luiz Eduardo Catta apresentou sua dissertação de mestrado ${ }^{6}$ sobre os impactos causados pela construção da hidrelétrica de Itaipu sobre a cidade. Em outra direção, diferentemente das questões apresentadas por Wachowicz, preocupado em descrever as causas, os entraves e as possibilidades de desenvolvimento da cidade de Foz do Iguaçu, desde seu surgimento, Catta, questionou a lógica implícita deste desenvolvimento, no contexto da construção da usina. Para ele, as transformações que determinaram o desenvolvimento urbano de Foz do Iguaçu, a partir dos anos de 1970, foram vividas como processo de modernização.

A investigação de Catta (1994) caminhou no sentido de problematizar as determinações e as conseqüências desse processo de modernização de Foz do Iguaçu, entendido como fenômeno característico de uma sociedade marcada pela exploração do capital sobre o trabalho. Sua leitura acerca das transformações vividas pela cidade preocupouse em ressaltar o caráter perverso do processo de crescimento produzido a partir da construção da Itaipu, que gerou um grande progresso tecnológico para o país, mas, simultaneamente, engendrou, no espaço urbano de Foz do Iguaçu, a pobreza e o aprofundamento das desigualdades sociais.

\footnotetext{
${ }^{6}$ CATTA, Luiz E. O cotidiano de uma fronteira: a perversidade da modernidade. Florianópolis (SC), 1994.
} 
Essa 'modernização', iniciada de forma mais eloqüente com o capital industrial nas áreas urbanas, foi responsável por um contingente de deserdados dos meios formais de produção, cuja herança foi relegá-los ao subemprego, à miséria, muitas vezes, ou à recorrência a expedientes informais de trabalho para sobrevivência, não cessou de se repetir, embora com formas e tonalidades diferentes. (CATTA, 1994, p.4).

Catta (1994) analisou esse processo de modernização, em Foz do Iguaçu, como parte do programa iniciado pelo governo federal, no contexto da ditadura militar, quando o Estado brasileiro assumiu as funções do grande capital, desenvolvendo o setor de bens duráveis, no sentido de dar suporte à acumulação privada nacional e internacional, no país. Neste sentido, a proposta de Catta consistiu em escrever uma história da cidade, cujo objetivo principal foi revelar os problemas urbanos, trazidos pela construção da Itaipu e seu projeto modernizador, responsável pelas transformações urbanas que deram uma nova forma à cidade e que a moldaram segundo os interesses do capital, e não das pessoas que nela viviam.

Por fim, como resultado dessa modernidade implantada na selva sub-tropical, na fronteira do Brasil com o Paraguai e Argentina, expressa, em sua configuração acabada, pela Usina de Itaipu e pelo poder que dela emanava e que a todos envolvia, buscamos destacar aquilo que de mais marcante sobrou como herança da implantação daquele projeto para a cidade e sua população: a transformação do espaço urbano de forma radical e abrupta, a emergência de uma população pobre [...] (CATTA, 1994, p. 8).

Essa abordagem sobre as implicações e significações da construção da hidrelétrica para a cidade de Foz do Iguaçu permitiu a Catta apresentar o ano de 1974 como um outro marco histórico, uma nova periodização da história da cidade. Segundo esse pesquisador, Foz do Iguaçu, desde o final do século XIX até o início dos anos de 1970, não viveu grandes transformações. Sua economia permaneceu baseada na atividade extrativista, durante todo esse período, primeiramente, por meio da extração de erva mate e, depois, a partir de 1930, 
com a exploração da madeira. O momento que marcou a transformação de Foz do Iguaçu teve início em 1974, com a construção da hidrelétrica de Itaipu.

Foz do Iguaçu foi, até a década de 1970, na visão de Catta (1994), um típico município do interior, uma cidade pequena, isolada no sertão brasileiro, onde o tempo corria devagar. Muito distante da agitação dos grandes centros urbanos, sua população vivia da exploração das riquezas naturais, como erva mate e madeira, e, de maneira irregular, do turismo nas Cataratas. A velocidade dos acontecimentos era determinada, fundamentalmente, pelas imposições da natureza.

Com apenas uma rua asfaltada, o que em si não constituía um problema para aquela população habituada com referenciais de cidade do interior distante dos grandes centros urbanos e que sempre viveu isolada em sua configuração espacial e cultural, as preocupações daquela gente voltavam-se para coisas que, na ótica das urbes 'civilizadas', representavam problemas demasiadamente modestos: a terra vermelha, das mais férteis do mundo, que deixava seus traços nas roupas, nas unhas, nas paredes, em todos os lugares; os extremos da temperatura, ora muito frio ora demasiadamente quente e que tornavam-se motivo bastante justo para longas conversas nos armazéns, nas reuniões familiares, nos encontros fortuitos pela cidade; os dias de chuva, que naquela região ocorria, nos períodos devidos, em grande abundância, levando a população ao isolamento temporário; o contrabando de madeiras pelo Rio Paraná, as caçadas pretéritas e futuras nas matas virgens da região. (CATTA, 1994, p. 26-27).

Foz foi descrita por Catta como uma cidade caracterizada por uma vida pacata, marcada pela proximidade física e social de seus habitantes, concentrados em perímetro urbano relativamente estreito, que impedia o distanciamento social entre seus habitantes:

Sendo um espaço urbano restrito, com 498,71 ha., com um número de 2.234 construções para uma população de 23.050 habitantes em 1973, praticamente a população da cidade se conhecia, ou no limiar, travava contatos, diretos ou indiretos, entre si, o que dificultaria a existência de casos extremos de pobreza em larga escala. (CATTA, 1994, p. 36). 
Ainda sobre sua idéia em torno da "proximidade social", Catta se baseou nos dados oficiais de 1974, os quais indicavam que Foz do Iguaçu apresentava uma densidade de 75 a 125 hab/ha, nos primórdios da construção da usina. A partir desses dados, o autor concluiu:

Essa concentração urbana em limites geográficos bastantes estreitos, permitia um intercâmbio contínuo entre as diversas famílias da cidade. Basicamente a grande maioria das famílias eram conhecidas entre si, mantendo-se uma sociabilidade em torno dos poucos locais de lazer que ali existiam, como o cinema, o cassino (do outro lado da fronteira, no Paraguai), as pescarias no Rio Paraná e Iguaçu, e nas festas da comunidade e da Igreja. (Catta, 1994, p. 28).

No entender de Catta, o distanciamento social era dificultado, também, pela ausência de grandes desigualdades sociais, pois, seguindo os dados da renda per capita, indicados pelo Plano de Desenvolvimento Urbano, produzido em 1974, havia, em Foz, um nível médio de riqueza entre seus habitantes ${ }^{7}$. Tomando como referência que a economia de Foz do Iguaçu era basicamente extrativista e que a população vivia da exploração de recursos naturais, Catta acabou produzindo uma narrativa romântica de uma cidade igualitária, onde todos podiam aproveitar suas riquezas.

O lazer da população estava ligado aos dois cinemas existentes, às visitas ao Parque Nacional onde existia um museu, às caçadas nas matas da região, às pescas nos rios Paraná e Iguaçu, aos jogos das 08 equipes de futebol, aos passeios e bailes das 06 Sociedades Recreativas e do Foz do Iguaçu Country Club. Em todos esses locais, praticamente toda a sociedade tinha acesso. (Catta, 1994, p. 24).

A imagem da cidade pacata permitiu ao autor realçar, ainda mais, os significados perversos da modernização, definida esta pela urbanização abrupta, acelerada, que corrompeu,

\footnotetext{
${ }^{7}$ Independentemente do valor da renda indicada pelo PDU (Plano de Desenvolvimento Urbano), é preciso ponderar sobre o fato de que a renda per capita é calculada com base no PIB (Produto Interno Bruto) da cidade, que resulta da soma de todas as rendas, dividido pela população. Todo esse cálculo não considera, por exemplo,
} 
de modo irreversível, a cidade, na sua forma e no seu conteúdo. No entender de Catta, "Com a chegada da Itaipu a vida de cidade do interior com sua mansidão e sossego começou a se desintegrar em relação às novas estruturas que iam rapidamente se moldando naquele espaço.” (CATTA, 1994, p. 31) Segundo este autor, após o início da construção da hidrelétrica, quando Foz do Iguaçu sofreu profundas transformações, engendradas por um processo modernizador trazido pelas elites, à revelia dos interesses gerais da população, a cidade, como era conhecida até então, foi destruída.

Os resultados desse incessante transformar-se, que representou, em grande medida, da vontade [sic] dos segmentos privilegiados da cidade, que passaram a dominar com maior ênfase as atividades econômicas e políticas, e que, aliadas ao Poder Público, detiveram, como de costume, a prerrogativa decisória sobre os assuntos de cunho social, impondo à revelia da vontade popular, seus projetos, segundo as conveniências do momento, foi [sic] a destruição sistemática de parte significativa de tudo o que foi erguido pelos antigos habitantes. (CATTA, 1994, p. 19).

As transformações ocorridas, a partir dos anos de 1970, em Foz, foram, segundo a perspectiva de modernização desenvolvida por Catta (1994), um processo que se impôs sobre a cidade e seus habitantes enquanto força material que, uma vez acionada pelas classes dirigentes, sob o imperativo dos benefícios do progresso, adquire vida própria e escapa ao controle de todos, promovendo todo o tipo de mudança, na cidade e na vida de seus habitantes. Com o desenvolvimento e a modernização trazidos pela construção da hidrelétrica, a mítica Foz do Iguaçu perdia sua fisionomia de cidade do interior, diante das inovações urbanas implementadas, a partir dos anos de 1970. Em lugar de ruas de terras, amplas avenidas asfaltadas. As antigas moradias de amplos jardins, com suas hortas e pomares, foram substituídas por edifícios modernos, lojas e shoppings. O impacto do progresso econômico se manifestava, também, na mudança arquitetônica da cidade, num processo em que, segundo o 
citado pesquisador, o passado é sinônimo de atraso, de destruição do velho e do antigo. No entanto, não se tratava apenas de apagar os sinais do passado pela destruição de prédios antigos e construção de novos, mas, também, de, progressivamente, transformar o espaço da cidade em mercadoria e em mercado, como observou Catta, no trecho abaixo:

O sintomático disso tudo, no entanto, é que os prédios mais antigos foram desaparecendo ao sabor das empreitadas do progresso e da modernidade, e em 1991 se resumiam a não mais que uma dezena, num universo de milhares de imóveis, que se encontravam na zona urbana e rural de Foz do Iguaçu. Foram sendo demolidos para dar espaço a prédios de estilo arrojado e satisfazer as exigências de um mercado imobiliário que crescia [...] também deram início à construção de Shopping Centers e lojas de comércio [...]. Foram de forma sistemática, reorganizando a cidade segundo o ponto de vista e os projetos das elites. (CATTA, 1994, p. 20).

Essas mudanças, indicadas por Catta, significaram mais que uma simples sucessão de demolições e construções. Tratou-se de um processo que alterou o modo de viver na cidade. As antigas moradias, com seus jardins e pomares, constituíam uma maneira de morar que não estava separada da maneira de viver e trabalhar. Sua destruição e substituição por grandes edifícios significaram a subversão desse modo de viver, em Foz, pois as novas edificações passam a ser construídas com o objetivo de atender os interesses e as regras do mercado. Uma outra racionalidade se impõe e redefine não apenas a forma, mas o próprio conteúdo da cidade.

Na visão de Catta (1994), Foz do Iguaçu foi atropelada pela dinâmica do progresso que desencadeou um crescimento demasiadamente acelerado para ser acompanhado por uma típica cidade do interior. O período que compreendeu a construção da hidrelétrica envolveu, também, o desenvolvimento de outras atividades econômicas, como o turismo e o comércio de importados do Paraguai, que alteraram sensivelmente a rotina da cidade. Embora Catta não 
seja claro sobre a associação entre estas atividades e a construção da hidrelétrica, em certa medida suas análises sugerem-na entre o turismo e a construção da usina, à medida que a Itaipu contribuiu, significativamente, para a formação de infraestrutura urbana necessária para tornar a cidade um ponto turístico. Para confirmar sua tese, aquele pesquisador apresentou dados que, na década de 1990, indicavam Foz como o terceiro maior parque hoteleiro do país, com 165 hotéis, capaz de receber 798.653 pessoas em visita às Cataratas, entre os anos de 1980 e 1992. A atividade turística aparecia, na percepção de Catta, como uma atividade econômica de grande significado para a cidade.

Nesta direção, a hidrelétrica foi, também no raciocínio proposto por Catta (1994), o grande vetor do processo de transformação econômica da cidade. A Itaipu produziu uma acelerada urbanização, por meio da construção de conjuntos habitacionais, investimentos na área de meio ambiente, investimentos em equipamentos urbanos públicos, construção de escolas e hospitais, investimentos na produção artística e na estruturação do turismo local. Em síntese, a usina de Itaipu foi, para Catta, o principal setor da economia local, não só pelo contingente de trabalhadores que empregou, mas, também, pelas rendas diretas e indiretas que gerou.

No entanto, em 1991, ao final da construção da usina, a cidade descrita e analisada por Catta (1994) era, antes de tudo, paradoxal. Era, ao mesmo tempo, um grande parque turístico, sede da maior hidrelétrica do mundo, e um centro urbano marcado pelo crescimento acelerado da pobreza. Ambas as características resultavam de um mesmo processo de modernização, promovido pela construção da Itaipu. Assim, a despeito de ter provocado um sensível desenvolvimento urbano, a construção da usina foi encarada, pelo autor, como o meio pelo qual se perverteram os ares da mítica cidade do interior com o desencanto da miséria. 
[...] constatamos que a implantação do projeto Itaipu, se por um lado foi o maior responsável pela organização da infra-estrutura básica da cidade, o foi também pelas enormes distorções a nível de concentração de rendas e de pauperização contínua de amplos segmentos da sociedade, que foram atraídos por ela, e se viram excluídos das atividades formais de trabalho. (CATTA, 1994, p. 97).

A imagem da cidade de Foz do Iguaçu, nos anos de 1990, pode ser contemplada pela síntese produzida por Catta, onde ele descreve a vida, na cidade, sob os efeitos das transformações engendradas pela construção da Itaipu e pelo chamado processo modernizador; o autor apresenta os sinais do absoluto caos urbano que passou a caracterizar a cidade de Foz do Iguaçu:

As principais consequiências dessas transformações foram:uma massa heterogênea vinda de toda as partes do Brasil e dos países vizinhos que passou a sobreviver, quando não absorvido pela economia local, de trabalhos informais ou de subempregos, [...] a criminalização da atuação desse segmento da população pelas elites, [...]; um favelamento acelerado nas áreas periféricas da cidade e um vertiginosos aumento da especulação imobiliária, desorganização das áreas centrais com um trânsito caótico, acidentes constantes, formação de comércio paralelo de produtos diversificados nas principais ruas da cidade, alto índice de criminalidade [...] e narcotráfico. (CATTA, 1994, p. 21).

Desse processo, resultaram três grandes problemas para a cidade: o aumento da pobreza, a falta de moradia e o aumento da criminalidade. Esses três grandes problemas decorreram, inicialmente, do acelerado e descontrolado crescimento demográfico, provocado pela migração de trabalhadores, vindos de toda parte do país, em busca de emprego na construção, criando demandas insustentáveis para a cidade. Além disso, havia, também, outros imigrantes que vinham para Foz com o propósito de trabalhar ou abrir pequenos estabelecimentos, nos setores do comércio ou de serviços, para atender uma presumida demanda produzida pela construção e o crescimento da cidade. 
O crescimento demográfico era determinado, inicialmente, por migrantes atraídos pelas empresas contratadas pela Itaipu, para agenciar mão de obra para a construção da Usina, e por pessoas que buscavam usufruir, indiretamente, do desenvolvimento causado pela construção. Além desses migrantes, Catta apontou que havia, também, inúmeros trabalhadores atraídos para Foz do Iguaçu por falsos agenciadores:

[...] os trabalhadores, principalmente os menos experientes e aqueles que nunca haviam trabalhado numa grande obra, estavam sujeitos a serem enganados pelos chamados gatos [...] Esses gatos [...] cobravam um adiantamento dos peões para vinculá-los às obras. (CATTA, 1994, p. 64).

Esses imigrantes chegavam em Foz, sem dinheiro e sem trabalho. Viviam nas filas de contratação da construção da hidrelétrica e faziam crescer, ainda mais, a população pobre excedente na cidade. De outro lado, à medida que avançavam a construção e os processos de desapropriação para a formação do lago da usina, paulatinamente, muitos antigos pequenos proprietários rurais migraram para as áreas urbanas, sem possibilidade de continuar sua vida no campo. Ao longo do processo de construção da usina, essa população excedente se ampliou, e sua composição foi se tornando cada vez mais complexa, devido ao êxodo rural e às demissões periódicas da construção da usina. A cada etapa vencida na construção da usina, grandes levas de trabalhadores eram demitidas, gerando um impacto social e econômico muito grande, na cidade. Ao contrário do que usualmente acontecia na construção de barragens, o conjunto dos trabalhadores contratados para Itaipu não foi embora. Neste sentido, Catta (1994) destacou, pelo menos, três fatores para explicar a permanência, em Foz, dos trabalhadores dispensados pela Itaipu.

O primeiro diz respeito ao fato de que "a Itaipu foi a última Usina Hidrelétrica de porte construída nos finais dos anos 80", devido à recessão que tomava conta do Brasil. O 
segundo fator concerne ao tempo de construção da Usina de Itaipu. A hidrelétrica de Itaipu levou dezoito anos para ser construída, enquanto as outras usinas levavam uma média de três ou quatro anos. Todo esse tempo permitiu que os trabalhadores se enraizassem no lugar: "Muitos ali se aposentaram, com bons salários, outros devido à estabilidade que adquiriram no emprego investiram em algum patrimônio". O terceiro fator refere-se ao fato de que Itaipu teria sido uma das poucas usinas construídas nas proximidades de "núcleos populacionais assentados e com dinâmica própria [...]” (CATTA, 1994, p. 65-66).

Catta não apresentou dados capazes de confirmar suas conclusões e contradisse-se, quando citou, como exemplo, operários que conseguiram permanecer trabalhando, até se aposentarem, e encontrando, desse modo, condições de continuar morando em Foz. Esse grupo, que certamente existiu, provavelmente não representou a maioria daqueles que trabalharam no curso desses 18 anos de obra. A contradição se expressou, justamente, no fato de que esse grupo não corresponde ao conjunto daqueles tantos trabalhadores dispensados pela Itaipu que, segundo a idéia desenvolvida por Catta (1994), fizeram crescer enormemente a população pobre da cidade. Apesar dos dados apresentados não serem de todo coerentes, as hipóteses de explicação propostas pelo pesquisador traduzem uma lógica que explica o aumento da população pobre, em Foz do Iguaçu, como resultado da permanência de imigrantes que foram para lá em busca de trabalho, na usina, principalmente se for considerado o fato de que as demissões maciças de operários ocorreram, somente, nos três últimos anos da construção. As demissões que aconteceram, neste ínterim, parecem ter sido muito menores. Além disso, o operário demitido tinha a possibilidade de ser reempregado, em outro setor, onde as obras estavam para começar. Isso, obviamente, contribuía para manter, também, a expectativa permanente de emprego entre os migrantes que seguiam permanecendo na cidade, até conseguir algum trabalho. 
A moradia se tornou, desde o início da construção da usina, um grande problema. Foz do Iguaçu não estava preparada para o contingente de trabalhadores que uma construção daquela magnitude implicava. As observações de Catta (1994) indicaram que, em 1978, no quarto ano da construção, o número de operários brasileiros alcançou o total de 20 mil pessoas, as quais, de um modo ou de outro, se relacionavam com a cidade.

Em 1974, ano de início das construções de Itaipu, quando começam a chegar as primeiras levas de trabalhadores para a obra, a cidade não possuía uma infraestrutura capaz de absorver aquele 'exército' de trabalhadores: moradias insuficientes para abrigar todo aquele contingente, e mesmo possuindo enorme apelo turístico, era deficitária quanto à hospedagem [...] (CATTA, 1994, p. 23).

Em socorro a essa realidade, caminharam os investimentos da Itaipu na construção de conjuntos habitacionais e em infra-estrutura urbana. Entretanto, estas construções só atendiam às demandas daqueles que trabalhavam na usina. Os outros segmentos da população e, principalmente, aqueles que migraram para Foz, a partir dos anos de 1970, dependiam da política habitacional, fosse do poder público municipal, do estadual ou do federal. Mas essa política era, segundo Catta, caracteristicamente deficitária. Então, para aqueles não empregados na construção e para aqueles não contemplados pelos programas de moradia popular financiada pelo governo, restava criar suas próprias formas de moradia.

Mais especificamente, criou-se um semicinturão de bairros populares/periféricos e aglomerados sub-normais que surgiram das concentrações de trabalhadores pobres ou desempregados nas áreas onde o Poder Público construiu, sempre em números reduzidos, moradias populares, e em áreas que foram sendo ocupadas espontaneamente. (CATTA, 1994, p. 103).

Nessa direção, o estudo de Maria de Fátima Bento Ribeiro (2002) problematizou o contraste entre as vilas construídas para os funcionários da Itaipu e as péssimas condições de 
moradia, caracterizadas pela proliferação de favelas, por toda a cidade. Como as vilas eram aparelhadas com todos os equipamentos públicos necessários, os trabalhadores quase não se envolviam com a cidade.

Durante a construção de Itaipu, e mesmo atualmente percebe-se um distanciamento dos trabalhadores de Itaipu, com relação à cidade de Foz do Iguaçu e aos seus habitantes. Estes trabalhadores interagem muito pouco com a cidade, não se reconhecendo como integrantes dela, e vice-versa, pois os habitantes da cidade também não reconhecem as vilas de Itaipu como parte da cidade. (RIBEIRO, 2002, p. 55).

Contribuíram para esse distanciamento o fato de que as vilas não foram construídas em um vazio demográfico. Ao contrário, o mencionado estudo de Ribeiro indicou que foram edificadas, em áreas habitadas, onde foram feitas diversas desapropriações para garantir sua construção. Na visão da autora, além de ter contribuído para uma urbanização acelerada e descontrolada, que provocou altos déficits de moradia e serviços públicos, em geral, devido ao crescimento populacional oriundo da migração, a Itaipu produziu desapropriações do solo urbano em seu favor. Desse modo, populações foram expulsas de seus antigos locais de habitação para a construção das moradias dos funcionários da hidrelétrica.

O mérito do estudo de Ribeiro reside na indicação de que a política habitacional de Itaipu baseou-se, em primeiro lugar, num processo de desapropriação e expulsão de moradores de seus lugares antigos de moradia. Além de ter sido ineficiente para solucionar a questão do déficit habitacional, ainda criou segmentação e hierarquização social, pelo padrão de moradia, entre a população de Foz do Iguaçu.

A cidade de Foz do Iguaçu passou a viver, desde então, na opinião de Catta (1994), um dramático processo de favelização, mudando drasticamente sua forma. Contribuiu para agravar esse quadro um processo de especulação imobiliária, provocado pelo 
desenvolvimento do turismo e pela expansão do comércio de fronteira ${ }^{8}$. Tais fatores inflacionaram o mercado imobiliário da cidade de Foz do Iguaçu, dificultando, ainda mais, a vida dessa população que, sem alternativa, passou a viver em barracos, em locais sem nenhuma infra-estrutura urbana ou saneamento. Os dados apresentados por Catta indicaram que, em 1991, havia, em Foz do Iguaçu, cerca de 2.965 famílias vivendo em "submoradias". (CATTA, 1994, p. 109).

Diante de tudo isso, ainda segundo Catta, a cidade foi, progressivamente, adquirindo uma nova feição, na qual predominava a pobreza, traduzida pelo crescimento da população desempregada e do trabalho informal. No período final da construção de Itaipu, Foz do Iguaçu havia se transformado em um grande mercado de trabalho informal, uma vez que, das 62.184 pessoas em idade economicamente ativa, apenas 29.963 eram oficialmente reconhecidas como população economicamente ativa. O restante, quando não amargava o desemprego absoluto, vivia em ocupações temporárias.

Foi neste contexto de crescimento da pobreza e da falta de moradia que Luiz Eduardo Catta identificou o crescimento da criminalidade, em Foz do Iguaçu, aquele que seria o terceiro grande problema surgido, a partir da década de 1970. O processo modernizador decorrente da instalação da Itaipu, que promoveu uma urbanização acelerada, associado à condição de cidade de fronteira, foi determinante para o crescimento da criminalidade, naquela cidade. De um lado, o processo de modernização acelerada apresentou muitas

\footnotetext{
${ }^{8}$ Catta (1994, p. 37) identificou, no período que compreendeu a construção da usina, o desenvolvimento de um forte comércio do Brasil com o Paraguai, graças aos acordos comerciais estabelecidos entre esses dois países. Esta atividade provocou um grande crescimento do setor comercial de ambas as cidades da fronteira, Cidade do Leste e Foz do Iguaçu. Curiosamente, os empresários estrangeiros que tinham negócios em Ciudad del Este árabes, chineses, coreanos - preferiam investir seus capitais em imóveis de Foz do Iguaçu, provocando uma elevação demasiada no preço dos aluguéis. Apesar de Catta (op. cit.) não apresentar nenhuma evidência a esse respeito, parece válido considerar a hipótese do processo inflacionário causado não necessariamente pelos investimentos estrangeiros, mas pela conjuntura econômica que a cidade vivia, dados: o significativo crescimento urbano, que produzia otimismo, no mercado imobiliário; o crescente fluxo de imigrantes, o que
} 
promessas de trabalho, prosperidade e desenvolvimento que não contemplaram a maioria da população que para lá migrou. Ao contrário, promoveram uma grande concentração de renda, aprofundaram as desigualdades sociais e fizeram crescer, sensivelmente, a população pobre e desempregada. De outro lado, Catta considerou o fato de Foz do Iguaçu ser uma cidade de fronteira e que, por tal motivo, atraía segmentos sociais marginais. Sob esta ótica, Foz atraía pessoas porque era, geograficamente, lugar de fácil circulação de bens e pessoas ligadas às atividades criminosas como roubo, narcotráfico e contrabando.

As instabilidades próprias das áreas de fronteira, que permitem uma circulação muito grande de produtos e pessoas, e que são esconderijos adequados para atividades marginais, favorecem o crescimento do número de atos ilícitos de toda ordem, bem como tornaram práticas comuns o contrabando, o roubo e o narcotráfico, praticados como alternativa ao desemprego [...]. (CATTA, 1994, p. 114).

Com essas últimas considerações sobre a criminalidade, o citado pesquisador concluiu o quadro de problematização do processo de urbanização/modernização, vivido por Foz do Iguaçu, entre os anos de 1970 e 1990. A modernidade e o progresso perverteram a cidade e o cotidiano de seus habitantes. Como objeto, a cidade foi moldada e modificada, segundo os planos de desenvolvimento econômico elaborados pelo governo militar - o principal agente dos interesses capitalistas, no Brasil, naquele momento. A modernização trouxe desenvolvimento econômico e tecnológico, mas, contraditoriamente, produziu uma cidade violenta e profundamente desigual, marcada pela pobreza, pelas favelas e pela criminalidade.

Foz do Iguaçu passou a abrigar um crescente número de marginalizados, excluídos dos meios formais de trabalho, dos quais muitos se tornaram criminosos, pessoas que migraram de outras cidades por problemas legais e que, pelas facilidades de tráfego entre as fronteiras, encontraram aí maiores

aumentava a procura por imóveis e, como desdobramento, aumentava, também, sua valorização; e o desenvolvimento econômico, proporcionado pela construção da Itaipu, pelo comércio com o Paraguai. 
facilidades para atuar [...]. Esse segmento social, acrescido e mesclado com aqueles personagens que afluíram à cidade em função da Itaipu, estarão no bojo dos problemas sociais que vieram a se configurar naquele espaço [...]. (CATTA, 1994, p. 35).

Em resumo, essas contradições enumeradas, Catta identificou aquela que chama ‘sentido perverso da modernidade': percebeu que foi a imposição da lógica produtiva capitalista que determinou a necessidade da super-oferta de mão-de-obra para a construção da usina, de modo a garantir a exploração dos trabalhadores por meio de baixos salários e precárias condições de trabalho. Parte significativa dessa mão-de-obra aglomerada, em Foz do Iguaçu, vivendo à espera de uma oportunidade de trabalho regular, foi convertida em uma população desempregada, pobre e sem moradia. Sua existência dependia de trabalhos fortuitos e, segundo Catta, em muitos casos, de atividades ilegais, tais como contrabando. A perversidade da modernização da cidade estava presente também nas mudanças:

E aí está seu lado perverso. Pois, ao mesmo tempo que edifica um "novo mundo", que constrói o "novo jardim", sem barro, sem poeira, limpo e arejado nas áreas nobres da cidade, atendendo aos anseios da elite e dos turistas, empurra para as áreas periféricas, para um mundo distante e sem flores, aquele populacho pobre que virá a constituir-se numa ameaça latente para esses mesmos edificadores e zeladores da ordem e do bem estar. (CATTA, 1994, p.38).

Se é verdadeiro que as reflexões desenvolvidas por Catta (1994), a respeito dos significados da modernização, contribuíram para problematizar e desmistificar o sentido positivo, atribuído por Wachowicz (1982) aos imperativos do desenvolvimento e do progresso, também é verdadeiro que ele reforçou outro mito: o mito da possibilidade de uma modernização sem seu "lado perverso", que produza um "novo mundo, sem barro, sem poeira, limpo e arejado" para todos e não somente para a elite, uma modernização fundada nos interesses humanos, e não nos mercantis. Em certa medida, as considerações feitas por 
Catta (1994) soaram como um lamento em relação aos efeitos da modernização, seja no apelo ao passado bucólico da cidade do interior, seja pela esperança depositada numa modernização mais humana. Todavia, retomando as discussões propostas por Marshal Berman (1986), a contradição é um traço inerente à modernidade, que atua, permanentemente, no tensionamento das relações sociais e não necessariamente como um poder absoluto das classes dirigentes. O lado perverso da modernidade não pode ser redimido, pois é ele, também, modernidade. Até mesmo essa dimensão perversa se revela também contraditória, como podemos ver nas considerações de Berman sobre análises feitas por Engels e Baudelaire, a partir do olhar destes, sobre a modernização do espaço urbano, empreendida por Hausmann, em Paris, no século XIX.

\begin{abstract}
As transformações físicas e sociais que haviam tirado os pobres do alcance da visão, agora os trazem de volta diretamente à vista de cada um. Pondo abaixo as velhas e miseráveis habitações medievais, Hausmann, de maneira involuntária, rompeu a crosta do mundo até então hermeticamente selado da tradicional pobreza urbana. Os bulevares, abrindo formidáveis buracos nos bairros pobres, permitiram aos pobres caminhar através desses mesmos buracos, afastando-se de suas vizinhas arruinadas, para descobrir, pela primeira vez, em suas vidas, como era o resto da cidade e como era a outra espécie de vida que aí existia. E, à medida vêem, eles também são vistos, visão e epifania. (BERMAN, 1986, p. 148-149).
\end{abstract}

Caminho contrário tomou Catta (1994), ao analisar as transformações da vida urbana de Foz do Iguaçu como resultado de um processo absoluto de dominação da máquina sobre o homem, do Estado sobre a sociedade, das classes dirigentes sobre os trabalhadores. Embora tenha desenvolvido uma crítica sobre as transformações vividas pela referida cidade, produziu uma visão nostálgica do passado e a ilusão de uma modernização sem contradições.

Nesta direção, caminhou, também, o estudo desenvolvido por Edson B. Souza (1998). Este autor partiu da premissa de que, se, por um lado, os processos de modernização são contraditórios porque trazem benefícios para a sociedade, tais como progresso econômico, 
desenvolvimento tecnológico, por outro lado, engendram problemas sociais. No entanto, na visão de Souza, tais problemas sociais podem ser contornados por meio do planejamento, um instrumento que deve ser capaz de prever os impactos e propor, antecipadamente, soluções. De modo geral, a preocupação central de Souza foi avançar na discussão sobre como o planejamento econômico e urbano atuou, no processo histórico de transformação da cidade de Foz do Iguaçu, a partir da construção da usina de Itaipu.

Assim como Catta (1994) havia indicado a ação do Estado como elemento determinante da construção da hidrelétrica, Souza (1998) buscou localizar, claramente, no poder público federal, a iniciativa primeira de criação de infra-estrutura para promover o desenvolvimento da indústria, no Brasil. Essa iniciativa, identificada por Souza, foi produzida no contexto da ditadura militar, quando

Através do II PND, o Brasil caminharia para o desenvolvimento. Para tal, a implantação de segmentos produtores de insumos básicos e de uma indústria de bens e capital de porte considerável fazia parte de uma fase recente do processo de industrialização. Para superar, conjuntamente, a crise e o subdesenvolvimento, o II PND escolhia superar a atrofia destes setores (insumos básicos e bens de capital) [...] Imprescindível às circunstâncias, o Estado adquiriu o papel de suma importância enquanto promotor de intervenção do processo industrial. (SOUZA, 1998, p. 20). ${ }^{9}$

Esse período dos governos militares foi, segundo Souza, caracterizado por um "surto modernizador" para o qual a construção da hidrelétrica de Itaipu concorreu fortemente, à medida que, como produtora de energia, criaria um dos meios fundamentais para a atividade industrial no Brasil.

\footnotetext{
${ }^{9}$ De maneira geral a sigla PND - Plano Nacional de Desenvolvimento - designa a estratégia adotada pelo governo militar, instalado no Brasil a partir de 1964, para promover o desenvolvimento brasileiro dentro dos preceitos da doutrina de segurança nacional. O I PND foi lançado em 1968 e sua prioridade foi garantir a expansão da produção de bens de consumo duráveis no país. O II PND foi lançado pelo presidente Ernesto Geisel (1974-1979). A característica fundamental do II PND girava em torno da proposta de priorizar os investimentos públicos no setor de bens de capital, com grande ênfase na produção de energia.
} 
Consolidação de uma economia moderna, mediante a implantação de novos setores, a criação e adaptação de tecnologias, como parte integrante do II PND, encaixa-se no propósito de suprir uma demanda emergente de energia, diante da crise de energia que afeta os fundamentos da sociedade industrial moderna. A hidrelétrica de Itaipu, engajada nesses projetos promotores de mudança, contribui na sustentação de uma estratégia de âmbito nacional. (SOUZA, 1998, p. 21).

O estudo realizado por Souza (1998) entendeu a construção da Itaipu como parte das políticas públicas, realizadas pelo governo federal, que consistiam não apenas no propósito de construção de uma usina, mas, também, no projeto de desenvolvimento, portanto, de modernização de Foz e de toda a região que seria atingida pela barragem. Esse processo modernizador implicou, ainda segundo Souza, a (re)configuração do espaço urbano e rural de Foz do Iguaçu e de toda a região alagada. A construção da Itaipu produziu novos espaços e ressignificou outros, mudando as dimensões territoriais, tanto do campo como da cidade, sempre de modo a atender às determinações do planejamento econômico do governo federal. Partindo desta premissa, Souza reafirmou a construção da usina, a partir da década de 1970, como o marco transformador da história da cidade de Foz do Iguaçu. Uma cidade que, embora tivesse um potencial turístico, não o desenvolveu de modo a operar grandes mudanças, no município, que, desde a década de 1930, viveu da atividade agrícola, sem conhecer grandes transformações. O momento de mudança na história da cidade viria, então, também segundo Souza, com a construção da hidrelétrica.

A nova dinâmica que Foz do Iguaçu conheceu foi com a Itaipu. Doravante um empreendimento que marcou a história mais recente do município, dividindo-se em dois períodos: antes e depois da obra, 'pois a partir de 1974, definiu-se uma nova fase de desenvolvimento do município que está intimamente ligada à 
implantação da Usina Hidrelétrica de Itaipu [...]'(PDDI-FI, 1992). (SOUZA, 1998, p. 36 ${ }^{10}$.

Associado à construção da usina Souza, identificou o desenvolvimento de outras atividades econômicas, em Foz do Iguaçu, que também contribuíram para as transformações que produziram um novo perfil para a cidade. A primeira se refere à intensificação das relações comerciais entre Brasil e Paraguai, a partir da década de 1980, que produziu um fenômeno econômico que ficou conhecido em Foz do Iguaçu como "turismo de compras" porque, de modo geral, a cidade se tornou o ponto de entrada de brasileiros interessados em comprar produtos eletro-eletrônicos, na Ciudad del Este, no Paraguai. Souza classificou esta atividade como de grande importância para a cidade, quando afirmou:

Esse turismo, o qual se convencionou chamar de 'turismo de compras', passou a assumir um papel preponderante na economia da cidade, pois movimentou e fez crescer o número de hotéis, restaurantes, lanchonetes, agências de turismo e outras empresas prestadoras de serviços, bem como absorveu grande parte dos trabalhadores do município. (SOUZA, 1998, p. 38).

Outra atividade destacada por Souza, neste contexto, foi a exportação, pois segundo sua avaliação, a carência de produção de bens de consumo, no Paraguai, abriu mercado para a formação de empresas de comércio exportador, na cidade de Foz do Iguaçu, que passou a se beneficiar com a venda de produtos como alimentos, vestuários e materiais para construção civil.

A construção da hidrelétrica implicou, segundo os apontamentos feitos por Souza (1998), a atração de correntes migratórias, que proporcionaram um crescimento demográfico significativo da população urbana da cidade. Souza observou, ainda, que este crescimento

\footnotetext{
${ }^{10}$ Para argumentar e justificar a importância da Itaipu, na história de Foz do Iguaçu Souza, o autor citou, nesta passagem, trechos do PDDI-FI - Plano de Desenvolvimento Integrado de Foz do Iguaçu, feito em 1992.
} 
demográfico se concentrou, fundamentalmente, na população urbana, que cresceu de 20.147 habitantes, na década de 1970, para 101.330 habitantes, na década de 1980, chegando a 186.486 habitantes, no início dos anos de 1990. Enquanto isso, no campo, a população rural diminuiu de 13.020, no ano de 1950, para 3.629, em 1991. Souza lembrou, ainda, que esse crescimento da população urbana não foi um fenômeno isolado. Ao contrário, fazia parte de um fenômeno que caracterizou o crescimento demográfico, no Brasil, que expressa a forte tendência à urbanização. Essa urbanização foi, segundo a interpretação defendida por esse autor, determinada pelos projetos desenvolvidos pelo governo federal, principalmente, nos anos de 1970, cujo objetivo fundamental era modernizar o país. Assim, Souza concluiu que, se muitos municípios apresentaram um crescimento da população urbana, devido à modernização da atividade agrícola (fator determinante na expulsão de grandes contingentes de camponeses para a cidade), Foz do Iguaçu viu sua população urbana crescer, em função de um grande empreendimento moderno: a construção da Itaipu.

O processo de urbanização de Foz do Iguaçu é parecido com o de outros municípios brasileiros, inseridos no desenvolvimento econômico e político do país, principalmente a partir da década de 70, acrescentando um ingrediente - a Itaipu. [...] Considerando que a construção da Itaipu acelerou o crescimento populacional urbano de Foz do Iguaçu na década de 70 e 80, outros municípios brasileiros também aumentaram o contingente populacional urbano em relação ao rural, mas ligados, principalmente, à política de modernização da agricultura que expulsou o trabalhador do campo para a cidade [...]. (SOUZA, 1998, p. 40).

$\mathrm{Na}$ análise desenvolvida por Souza, o rápido e intenso processo de urbanização não constituiu, em si, um problema. Ao contrário, constituiu-se num sintoma do desenvolvimento da cidade, pois, na sua opinião, a cidade de Foz do Iguaçu estava praticamente estagnada, antes da chegada da Itaipu. A intervenção do Estado, por meio de projetos modernizadores para o país, implicou necessariamente, segundo Souza, um impulso fundamental ao crescimento de Foz do Iguaçu, pois, em suas palavras: 
A Itaipu Binacional tem um grande significado na construção de Foz do Iguaçu. Foi através deste empreendimento do Estado que os efeitos negativos e positivos se mesclaram, produzindo uma nova maneira de concepção de cidade. Em pouco mais de trinta anos a cidade é a $5^{\text {a }}$ maior do Estado do Paraná. (SOUZA, 1998, p. 57. Grifo meu.).

Porém, associado ao crescimento urbano e ao desenvolvimento econômico da cidade, Souza observou o surgimento e o crescimento de inúmeros problemas sociais. O crescimento demográfico, causado pela construção da usina, impôs a necessária ampliação de equipamentos públicos como transporte, saneamento básico, bem como de ações de governo referentes a moradia, saúde e educação, que não foram supridos, na medida adequada,pelo poder público da cidade. Segundo os dados apresentados por Souza (1998, p. 38), o déficit de infra-estrutura, em Foz do Iguaçu, após o término da construção da usina, era de 4\%, em relação à água tratada, mas, em relação à coleta de esgoto, o déficit subia para $82 \%$. Em relação à habitação popular, faltavam 20 mil unidades, enquanto, na educação, havia, em 1994, carência de 150 salas de aula. Esses dados significaram, para o pesquisador, a comprovação da relação direta entre a construção da Itaipu e o desenvolvimento da cidade, bem como a incapacidade do poder público de atender às demandas que esse desenvolvimento provocou.

O término da construção da Hidrelétrica de Itaipu marcou o final de um período de crescimento para a região, principalmente para Foz do Iguaçu. Se de um lado as conseqüências foram positivas com o fortalecimento do setor do comércio, serviços e da construção civil, por outro lado, devido à incapacidade do município de atender uma demanda básica crescente, provocou carências sociais (saúde, educação, saneamento básico, habitação, etc), que o poder público local ainda não conseguiu satisfazer. (SOUZA, 1998, p. 38).

Para Souza (1998), a questão do déficit habitacional se convertia em valorização do solo urbano que, por sua vez, se traduzia em segregação espacial. A construção da Itaipu, acompanhada pela aproximação econômica entre Foz do Iguaçu e Ciudad del Este, contribuiu 
para inflacionar os valores de terrenos e aluguel. Segundo a avaliação daquele pesquisador, primeiro, a construção da usina provocou o crescimento acelerado e desproporcional da população urbana, ocasionando um grande desequilíbrio entre demanda e oferta. Num segundo momento, investidores da Ciudad del Este, atraídos pelas possibilidades de lucro, passaram a comprar imóveis, na cidade de Foz do Iguaçu, completando esse círculo de valorização do solo urbano e promovendo uma apropriação concentrada deste. Isto encareceu a vida dos trabalhadores, obrigando-os a viver em áreas periféricas, sem qualquer infraestrutura urbana. Nesta direção, Souza reforçou ainda que:

Importa salientar que os lotes vagos, no centro e nos anéis intermediários da cidade, são totalmente equipados com infra-estrutura e equipamentos públicos de consumo coletivo: água, rede de esgoto, ruas pavimentadas, transportes, escolas, postos de saúde, etc. Essas terras bem equipadas, que representam 34\% das áreas desocupadas em todo o perímetro urbano, são mantidas em estoque para o propósito de especulação. São de propriedade de pouquíssimas famílias e estão reservadas para uso das classes médias e alta, evidentemente. [...] as áreas periféricas são desprovidas da maioria dos serviços públicos acima nomeados e não dispõem de uma formação eficiente de centro de bairro que induza à polarização do comércio. Estes fatores se associam ao valor potencial desses terrenos que decrescem ainda mais, quanto menos serviços públicos dispuserem. (SOUZA, 1998, p. 49).

Ainda relacionado aos efeitos do crescimento demográfico, Souza (1998) identificou o que ele chamou 'formação de uma população flutuante', quando Foz do Iguaçu passou, a partir dos anos de 1990, a receber um número relativamente grande de turistas, interessados em fazer compras na Ciudad del Este, no Paraguai. Os dados apresentados pela FOZTUR indicaram que passaram pela cidade de Foz do Iguaçu cerca de 12.300 pessoas por dia, no ano de $1995^{11}$. Na avaliação de Souza (1998),esses dados constituem um indicador de um grave problema para o poder público, uma vez que tais turistas não estabeleciam nenhum vínculo econômico com a cidade. Esses turistas chegavam e voltavam, no mesmo dia, destinando todo

\footnotetext{
${ }^{11}$ Dados compilados de SOUZA, E. B. 1998, p. 42.
} 
o tempo que ficavam às compras no Paraguai. Esse comportamento parece ter favorecido a concentração de camelôs, próximo à Ponte da Amizade, o principal acesso à Ciudad del Leste, os quais implicam a construção de banheiros públicos e limpeza pública. Além disso, segundo o pesquisador, essa "população flutuante" contribuía para diminuir a vida útil dos equipamentos urbanos, que se deterioravam rapidamente, diante do uso constante. Ademais, esse fluxo permanente foi determinante para agravar os indicadores sociais, contribuindo para o aumento da prostituição infantil e para o tráfico de drogas.

No entanto, ao tentar explicar as razões dessas contradições que cercaram o processo de crescimento e desenvolvimento de Foz do Iguaçu, Souza (1998) argumentou que houve, por parte da Itaipu, a preocupação de discutir os impactos da construção da hidrelétrica de modo a apresentar um planejamento capaz de contornar e amenizar seus efeitos sobre a população atingida pela barragem. O autor ressalta que, no início da construção, em 1974, já havia sido formulado o Plano de Desenvolvimento Integrado (PDI). Em relação à cidade de Foz do Iguaçu, este planejamento pode ser verificado, nos planos diretores de 1974. Criados pelo poder municipal, com o apoio da Itaipu, esses planos serviram de instrumento para aplicação das propostas de desenvolvimento do governo federal não só para Foz, mas para toda a região. Nesta direção, Souza destacou como o plano apresentado em 1974 conseguiu apontar as diretrizes da ação do governo, no sentido de adequar a cidade à nova realidade imposta pela construção da hidrelétrica.

Tais circunstâncias causadas pela Itaipu foram previstas no PDDI-FI, 1974. Considerava este Plano que haveria necessidade de programação de mecanismos disciplinadores do desenvolvimento da cidade de Foz do Iguaçu, tendo em vista principalmente, a construção da Usina Hidrelétrica de Itaipu; a conveniência de elaboração de um Plano Diretor, visando à implantação, na área da cidade, da infra-estrutura e das instalações compatíveis com o apoio do projeto de Itaipu; e a necessidade do equacionamento dos principais problemas da área, alinhando as diretrizes nos campos físico-territorial, econômico, social e institucionaladministrativo. (SOUZA, 1998, p. 26). 
Sinteticamente, o objetivo desse plano era promover o desenvolvimento de políticas públicas capazes de adequar a infra-estrutura urbana de Foz à crescente demanda que se criaria, a partir da construção da Itaipu, de modo ordenado e harmonioso, evitando grandes traumas à cidade e à população. Simultaneamente, o plano deveria apresentar uma alternativa econômica que fosse capaz de sustentar de maneira permanente o novo núcleo urbano que surgiria, a partir da implantação da Itaipu. O turismo foi indicado como alternativa econômica, desde então, para promover o desenvolvimento de Foz e dos municípios cuja parcela do território seria atingida pela barragem. O planejamento apostava no incremento de mecanismo de exploração das belezas naturais de Foz do Iguaçu e das praias artificiais, na região alagada, para garantir um desenvolvimento econômico futuro. Todos esses elementos levaram Souza à conclusão de que o governo federal e a prefeitura de Foz tinham conhecimento dos problemas sociais que poderiam decorrer da instalação e da construção da usina e, por isso, desenvolveram o Plano Diretor, com o objetivo de adequar a cidade às novas necessidades que a construção da usina criaria.

No entanto, o governo federal não conseguiu aplicar efetivamente seu planejamento à cidade de Foz do Iguaçu. Desse fracasso decorreram, então, conforme Souza (1998), os grandes problemas urbanos que passaram a caracterizar aquela cidade: o déficit de moradia, o aumento da violência e da criminalidade, e a crise econômica dos anos 1990. Entre os anos de 1970 e 1990, Foz foi palco da uma rápida modernização, com a construção de grandes avenidas, prédios e hotéis, num processo crescente de valorização dos imóveis urbanos, que permitiu uma apropriação concentrada do solo urbano por setores mais abastados. Os investimentos realizados para o desenvolvimento da atividade turística terminaram por privilegiar uma minoria, na cidade. A maior parte da população com dificuldades de pagar até mesmo o aluguel foi viver em favelas. 
Concorreram para esse fracasso as próprias contradições das políticas públicas formuladas e desenvolvidas pelo governo. O primeiro fracasso resultou do fato de que os governos militares e as políticas públicas, reproduzidas em níveis regional e municipal, no país, se caracterizaram por investir muito mais nos empreendimentos econômicos do que nos sociais. A despeito de terem sido realizados inúmeros investimentos na estrutura turística, o déficit de equipamentos públicos de uso coletivo, a falta de uma política habitacional popular e de controle dos ganhos privados impediram que o turismo se desenvolvesse como elemento de sustentação econômica da cidade.

Por outro lado, esse fracasso resultou, também, da contradição entre a política econômica $^{12}$, implantada, pelo governo, na década de 1990, e a base da atividade econômica local, fundada no turismo, nas Cataratas, e no turismo de compras e extremamente dependente de um cambio desfavorável à moeda nacional. A entrada do Brasil no Mercosul e o Plano Real impuseram uma grande crise à economia de Foz do Iguaçu, comprometendo, assim, o planejamento feito, inicialmente, pelo governo militar, de elevar o turismo - considerada sua vocação econômica natural - à condição de principal atividade econômica, promotora do desenvolvimento da cidade.

A iniciativa do Plano Diretor, de 1992, visava promover melhorias na estrutura turística da cidade, recuperando o projeto de construção da Avenida Beira Rio - um dos projetos não realizados do Plano Diretor, de 1974 -, mas demonstrou as dificuldades do Estado de planejar as políticas de desenvolvimento urbano. No Plano Diretor, de 1974, o projeto da construção da Avenida destinava-se a formar um "eixo de aproveitamento turístico", ao longo das margens do rio Paraná, que ligaria Argentina, Brasil e Paraguai, numa ampla e contínua via expressa. Mas a cidade havia mudado muito, desde a década de 1970.

12 Plano Real. 
Do início da década de 1970 até o início da década de 90, a área de Foz do Iguaçu sofreu mudanças a partir de novos arranjos espaciais. Não só com obras públicas e privadas, como remodelamento das ruas e avenidas, construção de residências e prédios, mas também com a ocupação clandestina e o recrudescimento do comércio local e fronteiriço que contribuíram para que a Avenida Beira-Rio assimilasse uma nova concepção. (SOUZA, 1998, p. 70-71).

Apesar de, oficialmente, a obra ter sido justificada como obra de infra-estrutura turística, a nova conjuntura lhe atribuiu outros propósitos, como desafogar o trânsito concentrado nas avenidas Brasil e Schimelfeng, expulsar as favelas da região central da cidade e promover especulação imobiliária. Como a execução do projeto Avenida Beira-Rio implicava remover as favelas das margens do rio Paraná, o governo se viu obrigado e encarar o problema da falta de moradia, na cidade. As populações residentes nas favelas não aceitaram o projeto de expulsão dessas áreas e se organizaram para garantir seu direito de moradia. A construção da avenida foi, neste sentido, marcada por profundos embates entre o poder público, que representava, também, naquele momento, os interesses das imobiliárias, dos donos de hotéis e agências de viagens. Mas os conflitos não foram apenas sociais. De outro lado, a construção encontrou resistência também entre os estudantes, que questionaram seriamente o impacto ambiental da obra.

Todo esse intenso processo produziu uma cidade diferente daquela pretendida pelo Plano Diretor, de 1974. A cidade foi, nesse sentido, modelada não só pelos planejamentos do governo, mas pelos setores populares e pela forma de organização social de luta por moradia, pelos donos de hotéis e comerciantes, pelos agentes ambientais, pela dinâmica econômica ligada ao comércio, ao turismo e à construção da Itaipu. Entretanto, essas características da urbanização de Foz do Iguaçu, onde prevaleceram vários agentes sociais, econômicos e políticos, capazes de modelar a estrutura da cidade, foram consideradas problemáticos por Souza (1998). Apesar de reconhecer determinados níveis de disputa entre os setores 
populares, o Estado e o Capital, no sentido de estabelecer parâmetros mais igualitários para definição e aplicação das políticas públicas, o autor concluiu que a urbanização de Foz foi caótica, pela falha de planejamento do Estado, pois ao Estado cabia o papel de garantir um desenvolvimento harmonioso, sem grandes distorções sociais.

Neste caso, para o citado pesquisador, a cidade seria, antes, o objeto privilegiado da intervenção planejada e organizada pelo Estado. A análise desenvolvida por Souza (1998) construiu uma história da cidade, como história das políticas públicas, dos planos de desenvolvimento e modernização da economia, do planejamento urbano. A cidade, nesses termos, foi resumida à condição de um objeto sobre o qual operam as forças do Estado, na direção de definir sua forma, sua função e, acima de tudo, seu destino. De forma semelhante, o estudo de Catta (1994) também reduziu a cidade à condição de objeto da ação caótica e perversa da modernidade, entendida, assim, como exercício exclusivo dos interesses do capital, na adequação do espaço urbano.

De modo geral, estes três autores - Wachowicz (1982), Catta (1994) e Souza (1998) pensaram a história de Foz do Iguaçu a partir do paradigma do desenvolvimento e da modernização. Esta foi a problemática que permeou seus estudos sobre a cidade, seja no sentido de reconhecê-la como necessária, enquanto processo civilizatório, como pode se verificado nos estudos de Wachowicz, seja no sentido de questioná-la como processo contraditório e caótico de urbanização - como o fez Catta, ou como pode ser percebido no trabalho de Souza, em que a modernização deveria ser expressão de uma forma planejada de organização do espaço urbano.

O caminho trilhado pelas pesquisas e pelos estudos sobre a história de Foz do Iguaçu é curto, são cerca de vinte e quatro anos apenas. Ainda que consideremos as importantes contribuições feitas, até aqui, isso revela, em certa medida, o muito que há por fazer. A obra 
escrita por Wachowicz construiu dois marcos históricos importantes para a cidade de Foz: a criação da colônia militar, como marco fundador, e o ano de 1930, como marco do início da transformação modernizadora. A partir da análise dos relatos de viajantes e administradores locais, Wachowicz escreveu uma história da cidade que, em algum grau, também reproduziu os interesses e valores dos setores dominantes, principalmente, quando aceitou a grande presença dos estrangeiros como sendo um problema, sem discutir os diferentes significados do contato intenso entre brasileiros, argentinos e paraguaios. Criticou o sistema de exploração das obrages porque era estrangeiro e baseava-se no contrabando, e não porque era um sistema de exploração dos trabalhadores da cidade e da região. De sua pesquisa, não se tem notícia dos conflitos sociais existentes, na colônia ou na cidade; as questões que envolviam o desenvolvimento da cidade eram a maior presença ou ausência do poder do Estado, o grande agente modernizador da cidade

Os estudos realizados, na década de 1990, permaneceram com a discussão sobre a modernização de Foz do Iguaçu e o papel do Estado, neste processo. Estes trabalhos foram importantes na construção de um novo marco temporal na história da cidade. A construção da hidrelétrica de Itaipu, a partir dos anos de 1970, foi apontada como um grande momento de transformação vivida por Foz do Iguaçu. E, nesta direção, a análise feita por Souza indicou como o projeto de construção da usina significou, paralelamente, a elaboração de um projeto de desenvolvimento também para a cidade de Foz do Iguaçu ${ }^{13}$. O papel do Estado ganhou relevância como elemento fundamental do planejamento não apenas do desenvolvimento econômico, mas também do desenvolvimento urbano. Somente o Estado poderia ser capaz de promover um desenvolvimento que equilibrasse os interesses do capital e do trabalho, evitando os excessos e as distorções resultantes, seja pela ação da Itaipu, da rede de hotéis, das imobiliárias, representantes de interesses econômicos, de um lado, e, do outro, pela ação 
da população pobre, sem moradia e desempregada. Se não houvesse uma aplicação concreta dos objetivos do planejamento público, o desenvolvimento urbano da cidade seria desorganizado e caótico, refletindo os interesses dos grupos hegemônicos. As considerações de Souza (1998) sobre Foz do Iguaçu indicaram uma cidade onde miséria e pobreza prevaleceram, devido à ausência de um Estado capaz de equilibrar as forças sociais.

Num caminho um pouco diferente, mas ainda sobre o tema da modernização, Catta (1994) aponta reflexões bastante críticas sobre o significado do desenvolvimento urbano vivido por Foz do Iguaçu, desde o início da construção da usina hidrelétrica de Itaipu. A Itaipu se constituiu num marco da história da cidade de Foz do Iguaçu, porque alterou profundamente sua configuração urbana. Problematizando os significados do chamado progresso e do processo de modernização, trazidos pela construção da hidrelétrica, Catta chama a atenção para os aspectos negativos do salto demográfico vivido pela cidade, entre a década de 1970 e 1980, uma vez que ela já anunciava o problema da falta de moradia. Esta questão demográfica se tornou ainda mais preocupante, quando finalizaram as obras. Centenas de trabalhadores foram dispensados pela Itaipu, e formou-se, segundo Catta, um exército de pobres e desempregados, no município. A cidade que se projetou, nos anos 1990, foi construída, na avaliação daquele autor, a partir da destruição, da desconfiguração daquela existente, até os anos de 1970.

[...] foi a destruição sistemática de parte significativa de quase tudo o que foi erguido pelos antigos habitantes. Se num primeiro momento salta aos olhos os aspectos materiais dessa destruição e a reelaboração visual e estética que passou a cidade, a essência desse mudar estava na reorganização das relações estabelecidas entre as diversas classes, e que se projetaram de modo marcante sobre o tecido urbano. (CATTA, 1994, p. 19).

\footnotetext{
${ }^{13}$ Plano Diretor - 1974; Plano Diretor de Desenvolvimento Integrado - 1978.
} 
Nesses dois trabalhos, não foi possível perceber uma discussão crítica sobre a chamada vocação econômica de Foz do Iguaçu para a atividade turística. O aprimoramento da atividade turística, como mote para o desenvolvimento econômico da cidade, permaneceu naturalizado à medida que não se problematizaram os caminhos e os significados desta atividade, nem do ponto de vista econômico, nem do ponto de vista social.

Noutra perspectiva, pesquisas desenvolvidas, na primeira década de 2000, têm investido em discutir a presença dos trabalhadores, na região do Oeste do Paraná. São estudos importantes, à medida que abrem novas possibilidades de análise sobre a história dessa região, mas têm seu foco definido sobre as relações de trabalho ${ }^{14}$. Portanto, dessas iniciativas, incorporo as discussões realizadas por Emílio González (2005), que se propôs a tomar a cidade como espaço de disputa e de conflito social, seguindo um caminho de valorização das experiências de viver e de morar em Foz do Iguaçu.

González procurou estudar Foz do Iguaçu a partir das lutas, consideradas pequenas e cotidianas, de seus moradores mais humildes, em particular daqueles localizados em ocupações urbanas que formaram os bairros Jardim Morenitas I e II, realizadas na década de 1990. Esse recorte proposto pelo citado pesquisador, diferentemente daqueles propostos pelos autores debatidos até aqui, não tem uma função periodizadora, capaz de identificar o início da história urbana de Foz, a partir de datas de grandes projetos políticos e econômicos. Ao contrário, o recorte proposto articulou a história da cidade à história de seus moradores, à experiência contraditória e conflituosa de nela viver, morar e trabalhar. Compromissado com outros sujeitos sociais, o estudo de González (2005) orientou sua análise da formação urbana,

\footnotetext{
${ }^{14}$ SILVA, Elen. Trabalhadores na fronteira: experiências dos sacoleiros e laranjas em Foz do Iguaçu e Ciudad Del Este (1990-2006). Marechal Cândido Rondon (PR), 2008. MANARIN, Odirlei. Peões da barragem. Marechal Cândido Rondon (PR), 2008.CARDIN, Eric G. Sacoleiros e laranjas na Tríplice Fronteira: uma análise da precarização do trabalho no capitalismo contemporâneo. Araraquara (SP), 2006. GONZÁLEZ, Emilio. Memórias que narram a cidade: experiências sociais na constituição urbana de Foz do Iguaçu. São Paulo (SP), 2005.
} 
substituindo a questão da "origem" pela questão do "fazer-se", pois tomou o conjunto dessas experiências como parte dos processos que formam e constituem a cidade.

Assim, a nova abordagem do estudo feito por González (2005) reside na tentativa de discutir a produção social do espaço urbano da cidade de Foz do Iguaçu, a partir das experiências de homens e mulheres que, nos anos de 1990, produziram e participaram de ocupações de terrenos urbanos. Tal análise reconheceu, nos trabalhadores, agentes modeladores da cidade que, assim, foram tomados como sujeitos, quando desenvolveram ações que ordenaram a cidade com uma nova arquitetura, com uma nova dimensão geográfica e estabeleceram novas funções econômicas e sociais para os espaços urbanos ocupados. Nesta perspectiva, o processo de ordenação da cidade, que, até então, fora reconhecido pela historiografia local como sendo monopólio das classes dirigentes, passa a ser discutido, partindo da noção de que a cidade, antes de tudo, é um lugar de disputa.

Na maioria dos estudos realizados, os bairros periféricos resultaram da expansão da pobreza ou do exercício do poder público e das elites locais de expulsar a população pobre das áreas centrais. A periferia seria, portanto, por excelência, o lugar da exclusão. González (2005), por outro lado, observou como os movimentos de ocupações, que se iniciaram nos anos de 1980, contribuíram para um significativo aumento da malha urbana, uma vez que muitas ocupações incorporaram várias áreas ao perímetro urbano. Por isso, foi possível ao pesquisador inferir que, pelo menos em parte, a expansão da malha urbana ocorreu, também, em função das pressões das populações pobres e marginalizadas, que, ao ocupar terrenos públicos ou particulares, obrigaram o poder público a se pronunciar em relação à questão da moradia; e, nesta direção, esses movimentos acabaram por forçá-lo a construir o mínimo de infra-estrutura necessária para a habitação das populações mais pobres da cidade. A formação 
de moradias, na periferia, fosse por meio de ocupações e construção de favelas, fosse pela construção de casas populares ganharam um novo significado.

Seja no momento em que alargaram as fronteiras da malha urbana da cidade, ou no momento em que passaram a desencadear respostas da parte do poder público e empresarial, esses movimentos de ocupações urbanas foram, em certo sentido, o próprio motor do desenvolvimento urbano dessa cidade, e não reflexo dele [...]. (GONZÁLEZ, 2005, p. 61).

Além disso, ainda segundo González, a ampliação da periferia da cidade não poderia ser entendida, apenas, como processo de disciplinarização do espaço urbano, conforme as regras e interesses dos setores dominantes. A formação da periferia foi um processo conflituoso. Se havia, de um lado, a pressão do poder público e do empresarial para expulsar a população pobre de espaços urbanos melhores e mantê-la na periferia da cidade, de outro lado, havia, também, uma resistência por parte dessa população. As inúmeras ocupações urbanas constituíram uma expressão mais radical dessa resistência, porque nelas a população pobre tomava para si a decisão de onde deveriam morar, na cidade. Nesta direção, com observou Gonzalez:

Estes aspectos demonstram o quanto a ocorrência dessas ocupações operaram como agentes modeladores do espaço urbano para além de suas próprias fronteiras, forçando uma completa redefinição dos projetos oficiais e empresariais existentes para a área. (GONZÁLEZ, 2005, p.107).

Além disso, estas ocupações imprimiram um outro ritmo à expansão urbana. Esse movimento, de certo modo, interferiu na dinâmica da especulação imobiliária, pois os proprietários de imóveis nas áreas próximas ao Jardim Morenitas preferiram vender seus terrenos a correr o risco de tê-los invadidos. 
Analisando por este prisma, González apresentou novas dimensões da urbanização da cidade, onde o capital, os projetos das elites e do Estado não prevaleceram, absolutamente, sobre as demandas e necessidades dos setores empobrecidos. À história da cidade e de seu desenvolvimento urbano foram incorporados sujeitos sociais e, em particular, os trabalhadores pobres e marginalizados foram integrados à trama da construção da cidade. As ocupações urbanas contam, também, parte da história de formação da cidade, a partir da perspectiva de seus habitantes mais pobres, daqueles cuja sobrevivência física e moral depende, quase sempre, de sua capacidade de se equilibrar entre o legal e o ilegal, entre as estratégias de luta coletivas e as individuais.

Acompanhando a história da ocupação feita no Jardim Morenitas I e II, no Porto Meira, região oeste de Foz do Iguaçu, González (2005) revelou outras dimensões da vida urbana e de outros mecanismos utilizados pela população pobre para garantir o direito de morar, como no caso da comercialização dos terrenos ocupados. Os processos de ocupação são, recorrentemente, acusados pelo poder público de serem realizados por gente de má fé, que não precisa ter onde morar e só ocupa os terrenos para vendê-los depois. No entanto, por meio das entrevistas com os assentados, o pesquisador citado pôde perceber que essa tem sido uma alternativa para aquelas famílias muito pobres, que não puderam, por um motivo ou outro, participar da ocupação desde o início. Alguns não entram, logo no começo do processo, porque têm medo de ações violentas de desocupação, por parte do poder público. E há, também, aqueles que ouviram falar da ocupação e se deslocaram para a área ocupada. Ao chegar, muitas destas novas famílias encontram gente disposta a negociar o terreno da área recém ocupada. Trata-se de uma negociação pelo direito de ocupar e garantir o lugar de moradia, feita entre os próprios ocupantes. 
Os valores negociados são baixos e correspondem às possibilidades financeiras de uma população extremamente pobre. Para aqueles que chegaram primeiro, o parco dinheiro conseguido com a venda do direito de ocupar o terreno pode significar sua sobrevivência física, no próximo mês. O que indica que ninguém anda fazendo fortuna vendendo lotes de terrenos ocupados e não legalizados: para tais pessoas, muitas vezes, a venda do lote representa nada mais do que o pagamento de uma dívida ou a possibilidade de continuar sobrevivendo por mais um tempo. Para aqueles dispostos a pagar pelo direito este é o único investimento financeiro possível que têm para garantir uma moradia que, presumem, será melhor que aquela deixada para trás. $\mathrm{O}$ conjunto destas práticas revela as profundas contradições que permeiam não apenas a luta pelo direito de morar, mas a própria dinâmica da vida urbana, na sociedade capitalista. A ação coletiva de ocupação de terrenos pela população pobre pode ser entendida com um ato de absoluto desrespeito à propriedade privada e a todo o sentido de mercadoria incorporado ao espaço da moradia, uma vez que a ocupação privilegia o valor-de-uso - o direito de ter onde morar, em detrimento do valor de troca. Ao mesmo tempo, percebe-se, nessa mesma população pobre e marginalizada, o uso não organizado e individualizado da moradia, pelo seu valor de troca, dentro da lógica estabelecida pelo mercado imobiliário. No entanto, essas transações não são incorporadas pela formalidade do mercado e servem apenas como meios cotidianos de sobrevivência dos grupos mais pobres da classe trabalhadora que vive na cidade.

Ao lado dessas estratégias individuais, caminham as estratégias coletivas de luta, que buscam garantir um processo de legitimação e legalização de suas ações, por meio das negociações políticas junto ao poder público. Uma vez ocupados os terrenos, essa população criou uma associação para organizar a ocupação e negociar o processo de assentamento das famílias, o reconhecimento público de seu direito à moradia, a instalação de água, esgoto, luz etc. - enfim, toda a infra-estrutura básica para o local. Trata-se de tornar a ocupação um 
assentamento reconhecido pelo poder público e pelo antigo proprietário do terreno ocupado. Amparada pela certeza de possuir o direito de morar, essa população busca, então, legalizar um processo que, para eles, era legítimo. A formação de uma associação, entre os ocupantes, foi um instrumento privilegiado desse momento de legalização da área ocupada. Essa associação, chamada Comissão de Moradores, procurou garantir o fim da venda de terrenos e iniciou as negociações, em reuniões com a prefeitura e o proprietário do terreno. Segundo González (2005), esta Comissão teve grande importância no processo de consolidação da ocupação.

\begin{abstract}
Para alguns moradores, o trabalho que a Comissão desempenhou foi de vital importância para a consolidação da ocupação, não apenas porque encaminhou o processo de legalização da área, mas também porque ajudava a vigiar a área, mobilizar, designar membros para representar os interesses dos moradores mediante o poder público municipal, imobiliária, proprietária da área e até diante das forças policiais. Internamente, essa organização ajudava na vigilância da área, mobilizava moradores para fazer protestos, assembléias, discutir resultados das reuniões e apontar os caminhos existentes para o encaminhamento da legalização da área. (GONZÁLEZ, 2005, p. 116).
\end{abstract}

Por ter percorrido esse caminho das ocupações, a partir da fala dos trabalhadores na cidade, Gonzalez pode indicar outras possibilidades de compreensão da formação da periferia urbana de Foz do Iguaçu. A periferia seria, neste sentido, mais do que um depósito para os pobres e indesejáveis, mais do que resultado de processos econômicos irreversíveis. Numa perspectiva mais ampla, as ocupações feitas pelos setores pobres e marginalizados foram, também, uma forma de disputa pelo ordenamento da cidade, uma forma de disputa pelo direito de morar. Diferentemente de Souza (1998), em outra direção, González (2005) não caracteriza a disputa pelo espaço urbano, entre os vários agentes sociais, como um elemento negativo ou caótico, que demande a intervenção técnica e científica de agentes especializados a serviço do Estado, para garantir o desenvolvimento da cidade. Ao contrário, é justamente na 
disputa, no conflito, que se pode perceber que o processo de formação da cidade não resulta da ação inevitável e irresistível do capital, mas dos confrontos entre as classes sociais.

Contudo, se reconheço o valor na pesquisa de González, quando ele se propõe a discutir a cidade, a partir de processos e dinâmicas históricas, marcadas por disputas em torno do direito de morar, há que se criticar o peso exagerado que ele confere ao protagonismo dos moradores do bairro Morenitas. A tentativa de produzir um contra-discurso histórico tenha levado González, talvez, a tratar seus personagens como heróis. A passagem de sujeitos sociais excluídos a sujeitos sociais autônomos parece ter reduzido a dimensão e a complexidade dos conflitos investigados por ele, à medida que a história passa a ser enquadrada, exclusivamente, pela perspectiva dos moradores do Morenitas, perdendo aspectos importantes das lutas e disputas em torno da cidade.

Na perspectiva que busco desenvolver, tomar a história da cidade a partir do ponto de vista dos trabalhadores significa, antes de tudo, reconhecer as condições sociais, econômicas e políticas em que as experiências desses trabalhadores são produzidas, vividas e percebidas. O diálogo com a historiografia local foi, neste sentido, muito importante na definição da abordagem do estudo que me propus a desenvolver. A ausência de uma análise articulada dos diferentes sujeitos sociais, na história da formação urbana de Foz do Iguaçu, reforçou, ainda mais, os objetivos que me lançaram a esta pesquisa. Desse modo, cabe problematizar o processo histórico que tornou hegemônica a percepção da cidade de Foz do Iguaçu como cidade turística, considerando a presença dos diversos sujeitos sociais envolvidos em tal processo, bem como suas interpretações acerca da realidade histórica estudada. 


\section{CAPÍTULO 2.}

\section{O nascimento da cidade turística: a construção da memória dominante.}

Neste capítulo, pretendo discutir a formação da memória dominante sobre a cidade de Foz do Iguaçu. Para tanto, pesquisei documentação disponível, na Biblioteca Pública e na Biblioteca de Turismo, ambas de Foz do Iguaçu. São revistas, livros e álbuns produzidos entre as décadas de 1970 e 1990, que possuem um ponto em comum: são publicações dedicadas à construção de uma memória sobre a cidade, fundadas na idéia da vocação desta para o turismo.

Estruturei este capítulo a partir da análise dessas publicações, investigando quando, como, por que e por quem foi construída a idéia da vocação turística de Foz do Iguaçu. O conjunto dessas publicações é formado por:

a) O livro de memórias de Ottília Schimmelpfeng, "Retrospectos Iguaçuensens: narrativas históricas de Foz do Iguaçu.”, uma republicação, produzida em 1991, de textos escritos pela autora, para o Jornal da Foz, em 1970, e para a revista Painel, a partir de 1975.

b) A revista Painel, um periódico local, criado em 1973, e que segue sendo publicado até a presente data. Esta revista produz e divulga uma memória sobre Foz do Iguaçu, definida como cidade vocacionada para o turismo.

c) A revista Memória de Foz do Iguaçu, dirigida por Saulo Martins Brasil, publicada pela Editora Memória Ltda. Na Biblioteca Pública de Foz do Iguaçu , foram 
encontrados apenas três números: os dois primeiros, referentes ao ano de 1982, e o terceiro, ao ano de 1983.

d) O encarte em forma de jornal, Foz 80 anos: Memória, publicado, em 1994, pelo governo municipal.

e) O livro Foz do Iguaçu: Retratos, publicado, em 1997, pelo governo municipal.

Estas obras, dedicadas à produção e à conservação de uma determinada memória da cidade, foram publicadas num contexto de rápida transformação urbana de Foz do Iguaçu. De fato, estas publicações se estenderam por todo o período da construção da usina de Itaipu. O ambicioso projeto do governo federal de construir uma grande usina hidrelétrica, na região, foi desenvolvido, na cidade de Foz do Iguaçu e adjacências, e implicou, desde seu início, a alteração da estrutura urbana e da dinâmica social e econômica característica da cidade. Esse processo de mudança, desencadeado pela construção da hidrelétrica, parece ter repercutido, também, na própria dinâmica das relações dos grupos tradicionalmente dominantes da cidade. Inicialmente, para essas elites, as transformações geradas pela construção da usina constituíam-se num problema, justamente porque não estavam inteiramente sob seu controle e, deste ponto de vista, poderiam representar uma ameaça ao seu poder local. Desenvolveu-se, assim, uma relação contraditória entre as elites locais e o governo federal. Se, por um lado, as elites criticavam e ofereciam resistência à presença do poder dos tecnocratas encarregados de encaminhar a construção da hidrelétrica, por outro, viam, nesse processo, a chance de realizar seus projetos econômicos, na cidade. Tratava-se, portanto, de garantir que a presença do governo federal e de seus recursos servisse aos interesses destes grupos locais. Desse modo, transferia-se, para o governo federal, a responsabilidade de investir, se não de criar a infraestrutura urbana necessária para formar as bases econômicas que tornariam o turismo, em Foz 
do Iguaçu, uma atividade lucrativa para a elite local. Além disso, essa elite local não desconsiderava que a presença do governo federal, no processo de construção da usina de Itaipu, poderia promover uma significativa ampliação da circulação de capitais. Todavia, para conseguir operar essa inversão na relação de poder e realizar seus projetos econômicos, esses grupos locais precisavam constituir, em torno de si, uma legitimidade política e social suficientemente forte para enfrentar os agentes tecnocratas de um governo altamente centralizador e caracteristicamente autoritário do período militar.

Num contexto marcado por tais características, é possível compreender as iniciativas dos setores dominantes tradicionais ${ }^{15}$ da cidade de Foz do Iguaçu, na direção de produzir uma memória capaz de assegurar a importância dos grupos locais, diante dos novos grupos que surgiam a partir do início da construção da hidrelétrica de Itaipu. Os esforços dos grupos tradicionalmente hegemônicos dirigiram-se à produção de uma memória cujo conteúdo fosse capaz de moldar uma visão histórica de Foz do Iguaçu como uma cidade que, desde sua fundação, estava destinada a ser um centro de atração turística, para legitimar-se e, assim, consolidar seus projetos e interesses econômicos, no tempo presente, por meio do passado, mais especificamente, de um passado que articulasse a história dessas elites com a história da própria cidade.

No início dos anos de 1980, havia, em Foz do Iguaçu, uma significativa tensão entre alguns grupos locais e os grupos responsáveis pela construção e a instalação da usina de Itaipu. Por parte dos grupos que historicamente prevaleciam, na cidade, havia uma preocupação em defender sua posição de comando local, diante dos tecnocratas investidos de

\footnotetext{
${ }^{15}$ Compreendo como setor dominante tradicional o grupo social formado pela elite política da cidade, ou seja, o grupo social que dirigia politicamente Foz do Iguaçu, por meio do controle do poder público municipal. Essa elite local tradicional, a partir da construção da usina, se viu ameaçada pela presença de um outro grupo social, politicamente muito forte, constituído pelos tecnocratas representantes e condutores da política do governo federal, em Foz do Iguaçu.
} 
grande poder pelo governo federal. Tratava-se, naquele momento, de criar, para a cidade, uma identidade para se contrapor ao impacto da instalação da usina hidrelétrica. As elites locais iniciaram uma campanha em defesa de Foz do Iguaçu como cidade turística, que começou na década de 1980 e se estendeu pela década de 1990.

Desde o início do processo em que se discutiu e se definiu a construção da hidrelétrica, em Foz do Iguaçu, formou-se, na cidade, um ambiente de euforia, diante das possibilidades de desenvolvimento proporcionadas pela obra e, ao mesmo tempo, havia certo receio da perda de "autonomia" da cidade, diante da intervenção do poder federal. Nesta época, houve um significativo fortalecimento de um movimento de associação da cidade com a atividade turística. O turismo não era propriamente uma novidade. Ao contrário, já existia e baseava-se, fundamentalmente, na visita às Cataratas do Rio Iguaçu. O que havia de novo era a elaboração de uma proposição que identificava, nessa atividade, o núcleo para onde deveriam convergir todos os investimentos públicos municipais e, principalmente, federais. Desde então, o turismo passou a ser definido como a principal atividade econômica de Foz do Iguaçu. Alguns setores da sociedade local pretendiam promover seus interesses econômicos, por meio do desenvolvimento da atividade turística apoiada numa infra-estrutura construída pelo Estado.

Desse modo, ficou claro que a construção de uma memória de Foz do Iguaçu como cidade turística foi uma estratégia importante de legitimação dos interesses dos defensores dessa proposição. Afinal, a aceleração econômica e a expansão urbana, vividas pela cidade, a partir da década de 1970 foram desencadeadas, fundamentalmente, pela construção da usina de Itaipu. É nesse contexto que passo a examinar o processo histórico de construção de uma memória dominante, que tentou estruturar a cidade de Foz do Iguaçu como uma cidade vocacionada para o turismo. 


\subsection{0 mito das origens.}

Aos sujeitos produtores dessa memória de Foz do Iguaçu, sejam aqueles que se lançaram como testemunhos do passado da cidade, como foi o caso de Ottília Schimelpfeng, sejam os editores e jornalistas que organizaram e publicaram revistas, jornais, entrevistas, fotos e artigos com o objetivo de revelar o passado da cidade, vou denominá-los memorialistas locais. Apesar de estes se apresentarem como guardiões da história da cidade, seu trabalho se assemelha mais ao de produtores de uma determinada memória, cuja função principal é estabelecer uma linha de continuidade entre o tempo presente e o tempo passado. Um indicador dessa perspectiva, adotada pelos memorialistas locais, é o uso recorrente de relatos e descrições de viagens à Foz do Iguaçu $^{16}$. A expressão extrema dessa busca das origens está na incorporação, à história da cidade, dos relatos sobre a chegada de Núñez Cabeza de Vaca $^{17}$ às Cataratas, no século XVI. Neste caminho, a origem e o desenvolvimento da cidade se explicam a partir de seus atributos geográficos - as Cataratas e a fronteira. Ambos são tratados como elementos naturais da paisagem, que orientam os caminhos e descaminhos da história da cidade. Localizando o início do município onde ainda não havia a cidade, os memorialistas começam sua narrativa pela chegada do espanhol Núñez Cabeza de Vaca, por volta de 1542, à região, fato que marca o início da história da cidade e que se confunde com a referência espacial das Cataratas do Iguaçu, inicialmente denominada de

16 ABREU, C. F. de. A foz do Iguassú: ligeira descripção de uma viagem feita de Guarapuava à Colônia do Iguaçu em novembro de 1892. Curityba, 1896. IDEM. (1905). Visita ao Salto de Santa Maria. Curitiba, 1974. ASSIS, D. Nas barrancas do Alto Paraná. São Paulo, 1926. BALLÃO, J. A Fóz do Iguassú e as Cataratas do Iguassú e do Paraná: descripção de viagem. Curityba, 1921. BRITO, J. M. Descoberta de Foz do Iguaçu e Fundação da Colônia Militar. Curitiba, 1977. CABANAS, J. A coluna da morte. Rio de Janeiro, 1927. FIGUEIREDO, J. de L. Oeste paranaense. São Paulo, 1937. FRANCO, A. M. Recordações de viagens ao Alto Paraná. Curitiba, 1973. MURICY, J. C. da S. À Foz do Iguassú. Curityba, 1896. IDEM. Viagem ao país dos jesuítas. Curitiba, 1975. MARTINEZ, C. Sertões do Iguassu. São Paulo, 1925. NASCIMENTO, D. Pela fronteira: Paraná. Curityba, 1903. NOGUEIRA, J. Do rio Iguassú ao Guayra. Rio de Janeiro, 1920. SILVEIRA NETTO, M. de A. Do Guairá aos Saltos do Iguassú. [1914]. Curitiba, 1995. TAUNAY, Visconde de. Curiosidades naturaes do Paraná e excursão no rio Iguassu. Rio de Janeiro, 1890. 
Cataras de Santa Maria. Cabeza de Vaca é considerado pelos memorialistas o primeiro europeu a conhecer as Cataratas do Iguaçu. Desde o início, essa história sobre a cidade, contada e ensinada nas escolas (TESIN, 2001), entrelaça os caminhos das águas e da cidade, a fim de justificar sua vocação para a atividade turística.

Tal movimento relacionou a origem histórica de Foz do Iguaçu ao seu principal atrativo turístico, procedimento semelhante à prática da arqueologia, que busca explicar o presente pela maior longevidade que se possa alcançar em relação ao passado. Os relatos e descrições dos viajantes são, em relação a essa metáfora, artefatos arqueológicos cujo valor é estabelecido pela sua idade e, também, pela sua possibilidade de legitimação das memórias produzidas a partir da década de 1970.

A revista Memória de Foz do Iguaçu, dentro do universo das fontes encontradas, na Biblioteca Pública do município, foi a primeira a citar e publicar trechos de relatos de viagens feitas à região da fronteira e, em particular, à cidade. Os comentários e descrições, publicados a partir de relatos de viagens a Foz do Iguaçu, transformaram-se em recursos retóricos fundamentais para o delineamento do passado da cidade referido a uma evolução histórica de sua vocação: o turismo. Num trabalho de seleção, os memorialistas locais recolheram, apenas, aspectos da paisagem natural e social, presentes nos relatos e descrições de viagens, que lhes servissem como argumentos para a produção de uma memória da cidade de Foz do Iguaçu como lugar natural para o desenvolvimento do turismo.

A revista Memória de Foz do Iguaçu partiu da descrição feita por José Maria de Brito $^{18}$, em 1938, para valorizar o processo histórico que levaria à origem da cidade de Foz do

\footnotetext{
${ }^{17}$ NÚÑEZ CABEZA DE VACA, Álvar. Naufrágios e Comentários. Porto Alegre: LPM, 1987.

${ }^{18}$ José Maria de Brito foi sargento da Expedição Militar que, em 1888, foi organizada pelo Ministério da Guerra para descobrir a foz do rio Iguaçu e fundar a colônia militar. Ele descreveu e narrou os acontecimentos das expedições de 1888 e de 1889, por volta de 1936. Na apresentação de sua obra, as informações indicam que ele casou-se e viveu na região, foi Sargento Almoxarife e auxiliar da comissão fundadora da Colônia de Foz do Iguaçu, foi chefe dos toldos de índios do sertão guarapuano e foi, também, funcionário público.
} 
Iguaçu. Transcrevendo idéias e trechos escritos por Brito sobre a fundação da colônia militar de Foz do Iguaçu, a revista realçou o processo de formação da cidade, associada a um projeto nacional, de longa data articulado pelas mais altas esferas do poder federal. O início do artigo intitulado "Colônia Militar de Foz do Iguaçu - 1889: o começo", publicado na primeira edição da revista, fazia as seguintes afirmações:

Desde o ano de 1880, ainda antes da morte de Duque de Caxias, entre os oficiais do Exército mais aproximados do Ministério da Guerra, já era um dos assuntos mais discutidos a descoberta da foz do rio Iguaçu, principalmente por ser um ponto estratégico, diziam alguns. Propunha-se por uma idéia de fundar uma colônia Militar e construir um forte com capacidade suficiente para opor obstáculos a nações estrangeiras que porventura tentassem invadir o território brasileiro. Para completar cogitava-se em estacionar uma flotilha da Marinha brasileira nas águas do majestoso Paraná. (BRITO [1938], 1977 apud BRASIL, 1982, p. 8$)^{19}$.

Os trechos selecionados da obra de José Maria de Brito formam, no artigo da citada revista, um encadeamento harmonioso dos acontecimentos que levaram à fundação da Colônia Militar, sem a observância, por exemplo, da discussão sobre o modo como os militares foram recebidos pelos habitantes da região. Conduzido pelo olhar de um membro da expedição, o artigo reproduz a visão do colonizador e, ao mesmo tempo, identifica-se com um determinado passado que o torna herdeiro de uma determinada tradição. Trata-se de vincular o presente de Foz do Iguaçu a um passado marcado pelo espírito desbravador e nacionalista de defesa da nação. Essa citação revela, ainda, uma forma de naturalização do processo histórico de formação da cidade de Foz do Iguaçu. Relacionada, desde antes de sua fundação, ao projeto de defesa do território nacional, a cidade importa porque está na fronteira. A lógica que orienta a explicação sobre a origem da cidade tem como ponto de partida uma concepção

\footnotetext{
${ }^{19}$ Como esse artigo não identificou o autor, atribuí autoria ao diretor e editor da revista, Saulo M. Brasil, embora tenha constatado que o conteúdo da matéria constitui uma compilação do relato de José Maria de Brito, publicado no Boletim do Instituto Histórico e Geográfico do Paraná, em 1977.
} 
de que a fronteira é elemento natural da paisagem, conferindo à cidade uma posição econômica e geopolítica estratégica nacional.

A beleza natural da região foi, também, um outro elemento explorado, no referido artigo. E deste ponto de vista, o exercício de construção de uma memória para Foz do Iguaçu, realizado a partir dos anos de 1970, implicava tornar a natureza um agente histórico de legitimação dos interesses dos grupos dominantes locais. Não obstante a inquestionável beleza das Cataratas, esses grupos precisavam provar que as quedas sempre foram fator de atração e, neste sentido, fator privilegiado de desenvolvimento da cidade. A reprodução dos comentários e descrições de visitantes sobre o poder de mobilização e atração exercido pelas Cataratas, já desde o final do século XIX, constituía-se num elo entre os projetos de desenvolvimento do turismo em Foz do Iguaçu, afirmados tanto no presente como no passado, e a origem da cidade. Nas descrições dessa região, os aspectos selecionados são aqueles que podiam ser usados para confirmar a vocação turística das Cataratas, em Foz do Iguaçu, e das Sete Quedas, em Guairá.

Baseada nos relatos de José Maria de Brito, a revista Memória de Foz do Iguaçu selecionou e reproduziu um trecho em que o autor enfatizava o poder de atração das belezas naturais da região, quando da formação da segunda expedição organizada pelo Exército, em 1889, para fundar a colônia militar, na foz do rio Iguaçu. Selecionando trechos desses relatos, o editor Saulo Martins Brasil procurou convencer o leitor de que as Cataratas do Iguaçu e as Sete Quedas já representavam, naquela época, o principal fator de mobilização das expedições destinadas à fundação da colônia militar.

Foi então formada nova expedição, que voltaria a Foz do Iguaçu para estabelecer definitivamente a Colônia. Muitos militares da Comissão Estratégica e muitos civis queriam fazer parte da missão, movidos principalmente pelo desejo de conhecer as Cataratas do Iguaçu e as Sete Quedas de Guairá. (MEMÓRIA..., jun. 1982, p.9). 
Saulo Brasil deixou de transcrever o trecho em que José Maria de Brito afirmava que parte desse entusiasmo se devia à crença, cultivada entre os habitantes de Guarapuava, sobre a existência de ouro em pó na região "das quedas d'água”, como pode ser verificado nesta transcrição:

Emquanto Firmino dava os últimos retoques no relatório que devia apresentar, relativo aos trabalhos realizados e o autor desta narrativa passava-o a limpo, era de ver com que ancia se preparava a expedição já nomeada para fundar a Colônia Militar. Em Guarapuava, o assumpto mais interessante e discutido era a realização de tão auspiciosos commettimento. Muitos crentes na tradição, queriam acompanhar a expedição, anciosos para contemplarem as Sete Quedas e recolherem ouro em pó, que affirmavam existir nos sítios das quedas d'agua! (BRITO [1938], 1977, p.65).

Estes recortes, acompanhados de omissões de determinados termos ou mesmo de trechos das citações dos relatos mais antigos sobre Foz do Iguaçu, forjavam outros significados para as descrições do passado, de modo a contribuir para formulação de uma memória e uma história da cidade explicada a partir de uma origem, consubstanciada na vocação do turismo. As descrições foram apropriadas por vários autores, somente na medida em que confirmavam esta vocação.

Essas apropriações foram, em alguns casos, muito parecidas com um "recorta-e-cola" de diferentes relatos, num mesmo artigo. "A colônia Militar de Foz do Iguaçu - 1889: o começo", por exemplo, é formado por trechos compilados de José Maria de Brito, inseridos no início do artigo, e, na seqüência, excertos das narrativas de Cândido de Abreu, Domingos Nascimento e Silveira Netto, que informavam sobre as dificuldades, encontradas pela Colônia Militar, de promover o povoamento da região.

De maneira bastante clara, o grande problema identificado, nessa narrativa, era a presença das empresas argentinas, em território brasileiro, impedindo que quaisquer 
iniciativas econômicas pudessem prosperar. Cândido de Abreu, engenheiro, ex-senador e exprefeito de Curitiba, realizou duas visitas à Colônia de Foz do Iguaçu. A primeira, em 1896, e a segunda, em 1905. Em sua segunda viagem, serviu à Repartição Estadual de Terras do Estado do Paraná. Domingos Nascimento visitou Foz do Iguaçu, em 1903, e Silveira Netto, em 1905. Os trechos transcritos, pela revista Memória de Foz do Iguaçu, dos relatos de viagem destes visitantes formavam um texto crítico à presença e ao poder das empresas argentinas de exploração da erva mate e da madeira, caracterizadas como o principal obstáculo à fixação dos colonos nessa área. A colônia militar, apesar de seus esforços, seria incapaz de impedir a presença dessas empresas, na região. Porém, feitas as considerações que salvaguardavam as direções da Colônia Militar, o artigo seguiu criticando o poder das empresas argentinas, por meio dos argumentos desenvolvidos por Domingos Nascimento. A síntese destes argumentos pode ser identificada nesta passagem do artigo em que Nascimento explicava como a decadência da colônia e seu respectivo abandono pelos colonos eram causados pelo poder das empresas argentinas lá instaladas.

Ora, é sabido que estes (colonos) foram povoar aquela zona confiados na riqueza das suas florestas, onde deviam desenvolver os seus dois principais ramos de indústrias extrativas: a erva mate e a madeira, como assentamentos mais fáceis e sólidos para um começo de vida colonial. A lavoura se achava em embrião, mercados consumidores de cereais nem existiam ainda para os produtos da colônia. Constituindo, pois, aqueles dois ramos de trabalho a garantia única de vida dos habitantes, por sua grande exportação para os mercados platinos, e sendo os contratos feitos de maneira a consentir a invasão dos concessionários nos terrenos dos pobres colonos, a estes nada mais restava que abandonar as suas benfeitorias, indo procurar outros meios de trabalhar fora do Brasil ou se deixando ficar - escravizados à vontade e ao sabor dos capitalistas, como simples camaradas. (MEMÓRIA..., jun. 1982, p. 11).

Nessa mesma edição, a revista Memória de Foz do Iguaçu publicou trechos do primeiro capítulo do livro de Jayme Ballão, no qual o mesmo relata suas impressões da viagem feita à Foz do Iguaçu, em 1920, tendo dedicado, inclusive, um capítulo específico a 
descrever o município de Foz do Iguaçu. Nos trechos reproduzidos da obra, Ballão não poupou elogios ao processo crescente de urbanização da antiga colônia militar, emancipada em 1914.

\begin{abstract}
Adquirindo autonomia, a antiga colônia militar, sob a enérgica direção de operoso paranaense Jorge Schimmelpfeng, conseguiu alcançar em poucos anos o progresso que hoje ali se observa, atraindo a atenção dos poderes públicos para aquela região. Pouco a pouco, vencendo enormes dificuldades devido à situação de isolamento em que vivia o município afastado centenas de quilômetros do centro de ação do governo, tem o coronel Jorge Schimmelpfeng dotado o município de vários serviços de melhoramentos de grande importância. [...] A cidade construída em terreno bastante acidentado, tem suas ruas niveladas e algumas arborizadas e é iluminada a luz elétrica. A administração municipal com seus próprios recursos, tem construído e conserva várias estradas de rodagem e caminhos vicinais. (MEMÓRIA..., jun. 1982, p.39).
\end{abstract}

Porém, de acordo com a transcrição feita pelas revistas Memória de Foz do Iguaçu e

Painel, a avaliação de Ballão era de que essa evolução urbana de Foz do Iguaçu estava prejudicada pelas empresas de exploração de madeira e erva-mate. Repetindo alguns dos argumentos desenvolvidos por Domingos Nascimento e Silveira Netto, as análises do deputado Jayme Ballão afirmavam que "A indústria extrativa da erva mate e madeira tem prejudicado de alguma sorte o desenvolvimento da lavoura, porque aquela ocupação, sendo mais fácil é também mais lucrativa.” (MEMÓRIA..., jun.1982, p.40). Como essa indústria concentrava a maior parte da mão-de-obra na atividade extrativista, não havia como desenvolver a lavoura, tornando a cidade e a região dependentes da importação de alimentos. Pelas descrições de Domingos Nascimento, não era simplesmente o ato de importar gêneros de primeira necessidade da Argentina que aumentava o custo de vida, mas o fato de que esta importação era monopolizada pelas empresas extrativistas.

Apesar de não desenvolver uma crítica profunda sobre o papel das empresas argentinas de extração da madeira e da erva mate, as narrativas feitas por Ballão ofereceram à 
revista Memória... material suficiente para confirmar uma compreensão da história da cidade como história de sua vocação para o turismo. Ao final do artigo, a revista concluía, com os trechos da narrativa de Ballão, o autor apontava que o futuro da cidade estava, por assim dizer, na valorização de seus atributos naturais: a terra "fertilíssima" e seu principal atrativo: as cataratas.

\begin{abstract}
As terras são fertilíssimas e produzem abundantemente cana de açúcar, mandioca, frutas tropicais como a laranja e a banana, mamão, etc. Devem também produzir o café e o algodão, mas supomos que a cana de açúcar, o arroz e mandioca serão sua principal cultura. O principal atrativo da região é e continuará a ser cada vez mais, a visita às Cataratas de Santa Maria (hoje cataratas do Iguaçu), no rio Iguaçu e 'Guayra no Paraná'. (MEMÓRIA..., jun.1982, p. 38).
\end{abstract}

Apoiada nesses argumentos, desenvolvidos nos relatos de viagem, a revista Memória de Foz do Iguaçu publicou, em todas as suas edições, artigos criticando a exploração do mate e da madeira como fator de desenvolvimento de Foz do Iguaçu. Mesmo reconhecendo que esta atividade foi um grande gerador de atração dos colonos, não concordava com o monopólio das empresas argentinas sobre essa atividade econômica. Esse monopólio foi identificado pela revista como fator determinante no esvaziamento da colônia militar, pois impedia os colonos de se estabelecerem na região.

A revista Memória..., em suas três edições, manteve um padrão na apropriação que fez dos textos dos viajantes. Em seus artigos, sobressaia a intenção de mostrar que Foz do Iguaçu atraía a atenção de jornalistas, poetas e escritores pelas suas belezas naturais, já no início do século. No parágrafo introdutório, a revista sugeria que a cidade era tão interessante que despertou nele a vontade de escrever um livro: "O deputado Jayme Bailão fez uma viagem a Foz do Iguaçu no ano de 1920. Achou tudo tão interessante que resolveu escrever 
um livro do qual vamos retirar algumas partes que julgamos importantes na confecção desta revista." (MEMÓRIA..., jun.1982, p.38).

Neste artigo, a revista não explicou que esta viagem feita pelo deputado não fora um simples passeio: foi realizada com o objetivo de verificar as condições de tráfego e, deste modo, inaugurar a estrada de rodagem que ligaria Guarapuava a Foz do Iguaçu. O deputado Jayme Ballão partiu de Curitiba, em uma comitiva formada por autoridades estaduais e federais, por jornalistas e por um cônsul argentino para encontrar outro membro da comitiva, Affonso Camargo, ex-presidente do Estado do Paraná, e, então, seguiu para Guarapuava, onde começaria a viagem inaugural da estrada de rodagem. A omissão destes dados, presentes no livro, sugerem, mais uma vez, o esforço dessa revista para conferir à cidade um poder de atrair a curiosidade e de cativar seus visitantes, sugerindo que, desde muito cedo, Foz do Iguaçu poderia investir na exploração comercial de suas belezas naturais.

Ao mesmo tempo, essa valorização das riquezas naturais aparecia, na revistas, como crítica ao grande poder das indústrias extrativistas argentinas sobre as riquezas no território brasileiro. A partir dos trechos transcritos do livro de Silveira Netto, a revista Memória de Foz do Iguaçu publicou artigos que descreviam não só a riqueza das matas, mas que identificavam, no início do século, a preocupação com a ameaça de devastação representada pela exploração das indústrias extrativistas. Os comentários feitos pelo editor, sobre as obras de Domingos Nascimento e Silveira Netto, explicitam os interesses do autor, como registram os excertos a seguir.

Vários jornalistas, poetas e escritores já tinham vindo por estas fronteiras narrando suas aventuras nesta região. Entre eles, Domingos Nascimento que em 1903 escreveu uma obra intitulada 'Pela Fronteira', sendo premiada pelo Ministério de Agricultura deste Estado, pelo alto valor informativo, sobre a região. Denunciando o sistema de obrages, e meios de exploração argentina que estava acontecendo aqui. (MEMÓRIA..., abril 1983, p.13). 
Em 1914 foi editado um livro com o título 'Do Guayra aos Saltos do Iguassu' escrito por Silveira Netto. O livro foi publicado sob os auspícios da Secretaria de Agricultura e Secretaria da Indústria e Comércio do Estado do Paraná. Já naquela época o autor do livro se preocupava com a devastação das florestas e escreveu isto em seu livro baseado no que assistiu quando de sua viagem a esta terra em 1910. (MEMÓRIA..., dez. 1982, p.14).

As detalhadas e ricas descrições de Silveira Netto sobre a diversidade da flora regional, acompanhada de algumas ponderações sobre os perigos da devastação, também serviram de base para a revista apresentar sua crítica ao papel histórico do aproveitamento abusivo da madeira, no desenvolvimento de Foz do Iguaçu. Ao lado dessas críticas feitas a exploração predatória da natureza realizada pelas indústrias extrativistas estrangeiras, a revista Memória... destaca que estes viajantes reconheciam, já naquela época, o potencial turístico de Foz do Iguaçu.

\begin{abstract}
Em 1914 outro escritor paranaense nascido em Morretes (no litoral do Estado), também escrevia um livro chamado 'Do Guayra aos Saltos do Iguassu', isto em 1914, cujos relatos são de grande valor históricos, citando várias fontes de informação com referência a história de Foz do Iguaçu e da própria região oestina. [...] Um trecho muito interessante em seu livro é justamente sobre o Parque Nacional, cujo escritor dedicou um capítulo descrevendo as belezas naturais das Cataratas e da própria riqueza da flora e da fauna existente. [...] Foi também um dos grandes incentivadores para a criação de um Parque Nacional aqui em Foz do Iguaçu [...] e foi um dos primeiros divulgadores de Foz do Iguaçu pela imprensa [...] Provavelmente o primeiro áudio visual que foi mostrado publicamente sobre a região, foi elaborado pelo escritor Silveira Netto, com a colaboração de um amigo seu, o engenheiro Aristides de Oliveira, que após uma seleção escolheram 40 fotos das Cataratas do Iguaçu e começaram a fazer demonstrações sobre o potencial turístico, fazendo as projeções por sua conta. (MEMÓRIA..., abril 1983, p.13).
\end{abstract}

A revista referida utilizava os relatos de viajantes para explicar como o turismo fazia parte da história de Foz do Iguaçu, desde sua origem. O turismo seria, deste ponto de vista, a origem da própria cidade, o motor de formação e desenvolvimento do espaço urbano de Foz do Iguaçu. Essa conclusão está, aparentemente, na seqüência de acontecimentos passados, que 
mostram como o turismo sempre foi, desde o início da história da cidade, a vocação econômica desta. Entretanto, essa revista fazia muito mais do que uma busca pelas origens da cidade. O modo como Memórias... organizou e apresentou as narrativas dos viajantes sugeriu que sua busca projetava, no passado, a perspectiva de desenvolvimento turístico, vivenciada na década de 1980. Foi esta experiência, no presente, que permitiu à revista apresentar afirmações como esta: “A exportação de madeira e de erva-mate para a Argentina, foi uma fonte de renda muito volumosa talvez até importante, mas justamente nestes ciclos não se viu o progresso a olho nu como vemos hoje em dia.” (MEMÓRIA..., abril.1983, p.9). Para a publicação em tela, o motor do progresso local era o turismo. Sua leitura dos relatos dos viajantes foi orientada por esta perspectiva e, neste sentido, contribuiu para que organizasse o passado da cidade como uma evolução histórica do turismo.

A revista Memória de Foz do Iguaçu transcreveu trechos selecionados do livro de Jayme Ballão que formaram uma narrativa linear da evolução histórica da cidade. Entretanto, mesmo considerando o esforço do autor em conferir tal coerência ao conjunto de suas análises, e que o mesmo advogou em favor do desenvolvimento da atividade turística local, sua narrativa estava encerrada em uma contradição. No entanto, a descrição de viagem feita por Ballão indicou que a região e a própria cidade de Foz do Iguaçu eram dominadas pelas empresas argentinas de exploração de madeira e erva mate, enquanto o artigo publicado pela revista sugeria, ao contrário, que, na década de 1920, as empresas de exploração da madeira e do mate já tinham cumprido seu papel histórico, no povoamento da região, omitindo as passagens escritas por Jayme Ballão que indicavam justamente o oposto. Ao longo do livro de Ballão, encontram-se longas passagens que identificam a presença das empresas extrativistas e sua grande influência local, seja pelo número de trabalhadores que empregava, seja pelas estradas que construíra, seja pelos portos que fundara, seja pelo comércio fluvial que movimentava devido à exportação de madeira e erva mate para a Argentina. O poder e 
influência destas empresas pode ser percebido nestas três passagens, retiradas do livro de Ballão $(1921)^{20}$, nas quais foram descritas as recepções feitas pelas empresas de Domingos Barthe, Júlio Allica e Miguel Matte à comitiva do governo.

O doutor Affonso e comitiva, devido ao mau funcionamento do auto, no dia seguinte puderam apenas cobrir uma pequena distância alcançando o Depósito Central da empresa hervateira de Domingos Barthe, a 180 kilometros de Iguassu. Além de outros obséquios offereceu-lhes esta, um appetitoso churrasco, regado de bons e generosos vinhos argentinos. (p.17).

A chegada á villa Guayra, séde da administração da empreza Matte Laranjeira no Paraná foi alegremente festejada. Na estação aglomeravam todo o povo da villa, na sua quase totalidade peões da empreza, com seu característico poncho vermelho (colorau), uma orchestra de violinos e violões tocava na estação, outra na parte da administração e uma terceira na porta do hotel, onde fomos alojados. (p.23).

Em Porto Mendes aguardava a nossa chegada D. Ricardo G. Pereira, administrador da obrage Júlio Allica com seu automóvel para nos transportar por terra de Porto Mendes ao Porto Artaza (1 kilometro). Neste porto chegamos às 20 horas e fomos recebidos por D. Júlio Allica e sua exma. Senhora, na sua confortável vivenda. (p.27).

Tal poder de influência política se manifestava, também, no campo econômico. Os principais portos identificados por Ballão, quando chegou a Foz do Iguaçu, eram de propriedade das indústrias extrativistas: Porto de Santa Helena pertencia a Domingos Barthe; Porto São Francisco pertencia a Núñez Gybaja; o Porto Britânia, à Cia. Madeireira Alto Paraná; o Porto de Artaga era de propriedade de Júlio Allica; e o Porto Mendes pertencia a Miguel Matte. Com um município de $18.404 \mathrm{Km} 2$, Foz do Iguaçu, de acordo com as descrições de Ballão (1921, p.5 ), contou com a contribuição destas empresas para o seu povoamento, pois tinham ali grandes extensões de terras. Nessas descrições, estas empresas pareciam formar um grande complexo de exploração da erva-mate e da madeira, com capacidade de construir seus próprios portos e suas próprias estradas, e de promover a

\footnotetext{
${ }^{20}$ BALlão, Jayme. A Fóz do Iguassú e as Cataratas do Iguassú e do Paraná: descripções de viagem.
} Curityba, 1921. 
formação de núcleos urbanos modernos, como indicam os excertos (BALLÃO, 1921), a seguir.

\begin{abstract}
As empresas ervateiras de Domingos Barthe, Núñez Gybaja \&Cia, Júlio Allica, além de outras menores, como a de Fugêncio Pereira [...] trabalham com numeroso pessoal contractado, em geral paraguayos e argentinos. As 3 primeiras empresas tem construído centenas de kilometros de boas estradas de rodagem para o transporte de sua mercadoria. [...] As referidas empresas devassando o sertão e cortando-o de estradas, caminhos e carregadores tem feito outros serviços e melhoramentos para a exploração de suas terras e mattas. Nos portos de embarque e desembarque, abertos sobre o rio Paraná ficam geralmente armazéns, officinas e escriptórios das empresas. [...] Os portos são início de futuras povoações e algumas possuem elementos da vida urbana como a iluminação eléctrica. (p.5-6).

A nossa chegada a villa Guayra foi uma nova surpresa. Tínhamos notícia dos trabalhos realizados pela poderosa empresa naquellas longínquas paragens, mas tudo que havíamos ouvido ou lido a respeito está longe da realidade. A Matte Laranjeira fez do obscuro porto Monjoli a moderna e confortável cidade de Guayra. (p.20).

D. Júlio não possue senão 200 hectarees de terras, onde reside e explora hervais arrendados do Estado. Apezar disso tem construído 45 léguas de estradas de rodagem, uma linha telephonica de 120 kilometros, ligando o porto ao Depósito Central. Esta linha será prolongada até o Pequiry, com a extensão de 160 kilometros. Seus trabalhos estão já a 8 léguas do Campo Mourão. D. Júlio faz grandes plantações de milho, mandioca, cana de açúcar para abastecer seu pessoal. Trabalha com 940 operários, 80 carros, 870 mulas, e 140 bois, possue 600 vacas de criar, 3 autos. O Porto Artaza é iluminado á luz electrica por 125 focos, sendo a luz produzida por um dynamo de $10 \mathrm{HP}$ [...]. (p.29).
\end{abstract}

Por esse conjunto de trechos, foi possível perceber que, embora o deputado Ballão tivesse propugnado em favor do turismo e da agricultura, como alternativas de desenvolvimento de Foz do Iguaçu e Guaíra, a força da presença das empresas extrativistas argentinas não podia ser ignorada. Neste sentido, quando afirmou, em 1921, que "o principal atrativo da região é e continuará a ser cada vez mais, a visita às Cataratas de Santa Maria [...] e Guayra", ele, certamente, não se referia à realidade com qual se deparou. A base da economia, naquela região, incluindo a cidade de Foz do Iguaçu, era a extração de madeira e erva-mate. A visita às Cataratas, enquanto atividade econômica, estava longe de ser uma 
realidade. Não por acaso, Ballão baseava sua análise na experiência argentina de visita às Cataratas. Aliás, para o deputado, Foz do Iguaçu deveria aproveitar-se da estrutura de comunicação já construída pela Argentina para divulgar e atrair turistas para o lado brasileiro.

No lado argentino existem já dois hotéis regulares, sendo um no Porto Aguirre e outro junto aos Saltos. Com essas facilidades e a propaganda feita pela estrada de ferro Nordeste Argentino e Expresso Internacional de Buenos Aires o número de visitantes aumenta de anno a anno. Existe uma corrente de excursionistas, que, durante os meses de inverno para lá se encaminha. Esses visitantes com a próxima inauguração do 'Iguassu Cassino Hotel' procurarão sem dúvida nenhuma o novo estabelecimento não só pelos atractivos e commodidades, como ainda porque, do lado brasileiro, é onde estão, e de onde se pode com mais facilidade ver e admirar os maiores e mais bellos saltos. (BALLÃO, 1921, p.9).

Por outro lado, essa deferência de Ballão às obrages não pode ser reduzida à constatação do predomínio econômico das empresas estrangeiras de exploração da madeira e do mate, na região. Essas empresas tinham, também, uma grande força política que lhes assegurou a permanência e o direito de explorar a área. A fundação da Colônia Militar de Foz do Iguaçu e sua elevação à condição de município, em 1914, não alterou, concretamente, a atividade exploradora dessas empresas. Esse período caracterizou-se pela institucionalização dessa exploração pelo Estado. Segundo o levantamento feito por Wachowicz (1982, p.64), entre 1901 e 1916, foram instaladas, na área do município de Foz do Iguaçu, pelo menos, seis grandes obrages: Júlio Allica, Mate Laranjeira, Nuñez \& Gibaja, Domingos Barthe ${ }^{21}$, Compañia de Maderas Del Alto Paraná, e Petry, Meyer e Azambuja. O Estado, por meio da venda $\mathrm{e}(\mathrm{ou})$ arrendamento de terras devolutas às grandes empresas estrangeiras, autorizou a exploração da madeira e da erva-mate, na região da foz do rio Iguaçu, promovendo a

21 De acordo com Westphalen (1987, p.7), Domingos Barthe foi "um dos maiores concessionários de terras na região de Itaipu, no início do século, havendo desenvolvido intensa exploração de erva-mate e madeira (proprietário dos terrenos Paz, São Domingos, Pequery, Santa Helena, Barro Preto, Dois de Maio, São Francisco e Diamante).”. 
legalização da exploração ali realizada por estas empresas. Em seu estudo sobre a colonização desta região, Cecília Westphalen (1987, p.7) explicitou como o governo do Estado do Paraná estava implicado na forte presença de empresas estrangeiras naquela área, conforme o registro a seguir.

Com a proclamação da República e a adoção do princípio federativo, pela Constituição de 1891 as terras nacionais devolutas passaram ao domínio dos respectivos Estados. Deste modo, passaram ao Estado do Paraná as terras da região de Itaipu não apropriadas por proprietários privados até o final do século XIX. Na verdade, encontravam-se oficialmente na região, apenas a Colônia Militar de Foz do Iguaçu e a Companhia Estrada de Ferro São Paulo-Rio Grande, concessão de 1889, ainda no Governo Imperial, esta, porém com as suas terras ainda não medidas e demarcadas. Inúmeras concessões de terras foram realizadas pelo Governo do Paraná, na conjuntura da Primeira República (1889-1930), a partir da Lei de Terras n $1147 / 12$ e 1642/16, particularmente possibilitaram a concessão de áreas de 50 mil hectares para projetos de colonização. Deste modo, provocaram intensa movimentação fundiária no Estado. A efetivação da política de concessões de terras em áreas nacionais despovoadas geopoliticamente necessitadas de imediata ocupação resultou nas grandes concessões que constituíram os primórdios da colonização moderna da região de Itaipu. Todavia, é sabido que muitas dessas iniciativas foram unicamente favorecedoras de empresas estrangeiras atuantes na região e que a maioria delas na verdade, pouco ou nada contribuiu para sua colonização. Não resultaram na ocupação efetiva da terra, nem na sua distribuição por colonos, pequenos proprietários. Exploraram de modo predatório as matas e os ervais, com suas obrages e mensus.

Ao contrário do que sugeriam os inúmeros artigos publicados pela revista Memória..., a extração de madeira e erva mate realizada em Foz do Iguaçu, na primeira metade do século 
XX, não foi uma exploração feita à revelia das autoridades nacionais. Tais empresas contavam não só com o apoio do governo, mas, em certos casos, eram administradas e organizadas por autoridades públicas. Segundo Wachowicz (1982, p.163), o coronel Jorge Schimmelpfeng, primeiro prefeito de Foz do Iguaçu, dirigia, desde 1906, a Compañía de Maderas Del Alto Paraná, uma ramificação da empresa inglesa The Alto Paraná Development Company, cuja sede estava localizada em Buenos Aires.

Essa relação estreita entre as empresas estrangeiras e o governo do Estado do Paraná autorizou e garantiu, por meio dos títulos de propriedade ou de arrendamento, a exploração e devastação denunciada pelos viajantes que conheceram a região. Porém, em nenhum momento, esses viajantes discutiram a natureza da participação do Estado neste processo exploratório.

Os relatos, em sua maioria, naturalizaram a relação entre o Estado e essas empresas. Isso pode ser percebido nos relatos escritos por Jayme Ballão, particularmente, num trecho em que ele reproduziu um discurso proferido por D. Ricardo G. Pereira, administrador da obrage Júlio Allica, cujo conteúdo apresenta os termos dessa relação entre o Estado e as empresas estrangeiras.

Senor Representante Del gobierno Del Estado do Paraná, senores representantes Del ministro de Guerra, Viação y Agricultura; senores: acompañantes En nombre de mi mandatario, senor Júlio T. Allica cabeme la honra de tomar la palabra para expresarvos nuestro efusivo agradecimiento por esta gentil e honrosa visita. Quiero significarvos, también, que es esta la primera vez que el primer mandatario Del Estado do Paraná se ha resuelto a hacer una cruzada de 800 kilometros para internar-se en nestas regiones, significando para nosotros el mas efficaz y noble aliente, por cuanto que elle se desprende que a pesar de la enorme distancia non estamos tan alejados de Curityba, nen olvidados de los hombres que manejan el complicado engrenage del gobierno, que el exm. Afonso Camargo ha sabido fazer con tanto acierto y patriotismo [...]. Quiero también significar que esta pequeña población que esta está surgiendo aquí se debe única e exclusivamente al labor tenaz e constante que haya empeñado el Sr. Allica por indicación del distincto Dr. Candido de Abreu (aquí en paz descanse) que cruzo este lado y cual el anta silbador e curpolento entro derribando árboles 
y abriendo-se caminos a fuerza de machete, trabando-se una enorme lucha con la selva virgen, convertida hoy, en lugar agradable y con relativas comodidades, las que a medida de sus fuerzas se van ensanchando. Actualmente nuestros trabajos se encuentran a 45 leguas del aquí al otro lado del Piquiry y á 8 leguas del Campo Moron, tenemos una instalación telefónica de 20 Kilometros e muy breve por iniciativa del sr. Feliuto Braga y de común acuerdo ligaremos con nuestro teléfono á Catanduva e para antes finalizar el corriente anno tendremos también unidos nuestros caminos con el que viene de Guarapuava. Deseando también contribuir el sr. Allica á la nacionalizacion del grand parte del personal infantil, desde el próximo anno funcionará aquí una escuela gratuita que de acuerdo con los programas del Estado, aprendan los niños el portugués con la que poco a poco se les irá inculcando el amor a la nacionalidad brasileña y por ultimo para terminar, senores, largo votos para que el digno sucesor dr. Camargo, heye las rédeas del gobierno con el miesmo acierto y entusiasmo y que tenga la suerte de rodearse de colaboradores tan competentes y laboriosos como los senores Moreyra Garcez presente [...] este acto y el dr. Arthur Franco. Para terminar senores levanto mi copo y brindo por la prosperidad del Estado do Paraná - He dicho. (BALLÃO, 1921, p.27-28).

Tal relação foi omitida, também, nas publicações dos memorialistas, pois sua preocupação estava centrada em buscar, nos relatos dos viajantes, citações em favor do turismo, enquanto atividade econômica, segundo a qual se promoveria o progresso da cidade de Foz do Iguaçu. Neste sentido, as críticas feitas pelos viajantes à exploração estrangeira da madeira e da erva-mate foram apropriadas pelo discurso dos memorialistas, como um argumento de defesa do turismo. Em oposição à exploração predatória da natureza, feitas pelas Obrages, os memorialistas buscaram, no discurso dos viajantes, a defesa do turismo como atividade de exploração das belezas naturais sem sua conseqüente destruição. Admitir os vínculos econômicos e políticos entre o poder público e as obrages implicaria, para os memorialistas, reconhecer que não havia contradição de interesses entre os promotores do turismo e da exploração predatória empreendida pelas empresas estrangeiras. Afinal, segundo os memorialistas ${ }^{22}$ locais, um dos pioneiros do turismo, em Foz do Iguaçu, foi Jorge

${ }^{22}$ Em 1976, a revista Painel (n. 29) iniciou a publicação da coluna Otília Schimmelpfeng. Sob o título "Pioneiros do turismo iguaçuense", a coluna de Otília fazia sua homenagem às iniciativas de Frederico Engel e a seu pai, Jorge Schimmelpfeng. A revista Painel n.76, de julho de 1979, publicou um artigo sobre a homenagem póstuma aos pioneiros do turismo. No $65^{\circ}$ aniversário da cidade de Foz do Iguaçu, foi concedido, como homenagem póstuma, o título de cidadãos honorários a Frederico Engel e Jorge Schimmelpfeng, in memoriam. O 
Schimmelpfeng - dono de uma obrage. O próprio Jayme Ballão, quando se referia à importância do turismo, nas Cataratas do Iguaçu e em Sete Quedas, descrevia, com entusiasmo, as iniciativas de Schimmelpfeng e da empresa Mate Laranjeira.

Compreendendo isso, o coronel Jorge Schimmelpfeng, prefeito municipal tomou a iniciativa de construir, instalar e explorar o grande Hotel Cassino, enfrente aos Saltos, com o fim de attrahir corrente de excursionistas, proporcionando-lhes as necessárias facilidades e o desejado conforto para realização daquella visita. [...] O hotel ocupa um vasto edifício, especialmente construído para este fim, tendo de frente 30 metros e 10 de fundo, com dois pavilhões laterais de 30 metros por 6. Constará de sala para baile, salão de jantar, sala para jogo, quartos para hospedes, banheiros instalações sanittárias. E iluminado á luz elétrica e servido de água encanada. O Iguassu Cassino Hotel attrahirá e manterá a corrente de turistas não só do Paraguay, Argentina e Uruguai, como ainda do Brasil que são os que menos conhecem o salto. O hotel de Guayra mantido pela empresa Mate Laranjeira, no Alto Paraná, facilitará a visita ao grandes saltos das Sete Quedas. (BALLÃO, 1921, p.9-10).

Os relatos feitos por Jayme Ballão sugerem que não existia, necessariamente, uma contradição entre as obrages e o turismo, em Foz do Iguaçu. Além disso, suas observações sugeriram que parte dos primeiros investimentos na infra-estrutura turística tinha origem em capital advindo da exploração da madeira e da erva mate. Sob esta perspectiva, cai por terra a explicação, elaborada pelos memorialistas locais, que interpreta o predomínio da exploração de erva-mate e madeira, na região de Foz do Iguaçu, como um desvio histórico, engendrado por forças externas. Ao mesmo tempo, estas contradições expõem o modo como os memorialistas naturalizaram a história social e econômica da cidade, ao partir do pressuposto de que a existência das Cataratas, por si só, determinaram sua vocação ao turismo. Até o final da década de 1930, a exploração das obrages prevaleceu por toda a extensão do município de Foz do Iguaçu.

encarte 'Foz 80 anos: Memória', publicado em 1994, e o livro 'Foz do Iguaçu: Retratos', em 1997, também apresentaram Jorge Schimmelpfeng como um dos pioneiros das atividades turísticas, em Foz do Iguaçu. 
Com a decadência desse sistema, Foz do Iguaçu experimentou uma expansão da atividade agrícola promovida pela colonização organizada pelos governos federal e estadual, a partir da década de 1930. Por outro lado, a atividade de exploração da madeira se expandiu, também, pois o processo de colonização foi realizado por companhias brasileiras de exploração de madeira. Estas compravam terras, loteavam e vendiam-nas para os colonos vindos, principalmente, do Rio Grande do Sul e de Santa Catarina. Porém, antes de vender a terra ao colono, as companhias extraíam a madeira e exportavam-na, pelo rio Paraná até o mercado da bacia do Prata.(WACHOWICZ,1982,p.170). A atuação dessas companhias fez permanecer, em Foz do Iguaçu, a atividade de extração de madeira, mas também promoveu uma significativa expansão da colonização, a partir da década de 1930.

Comparando alguns dados de 1936, sobre a criação de animais, em Foz do Iguaçu (SILVEIRA NETTO, 1914, p.26), com a população pecuária indicada pelo IBGE (IBGE/PR, 1950, p.24), em 1948, percebe-se que houve um crescimento significativo desse setor. Tal crescimento parece, inclusive, ter impulsionado o desenvolvimento da indústria de alimentos, principalmente, de origem animal. Esta indústria produzia banha de porco, mel e cera de abelha, leite, queijo, manteiga e ovos.

Infelizmente, não foi possível comparar a situação da atividade agrícola, pois os únicos dados sistematizados são aqueles formulados pelo IBGE, em relação ao ano de 1948. Silveira Netto (1914) apenas citou, em sua obra, que a produção agrícola de Foz do Iguaçu era formada por “[...] milho, arroz, feijão, fumo, mandioca, etc.” e tece comentários sobre a existência de fábricas de rapadura, aguardente e beneficiamento de arroz. Apesar da falta de parâmetros de comparação, vale mencionar que, segundo o IBGE/PR (1949, p.26), havia cinco fábricas de aguardente em Foz, sendo duas delas localizadas na sede do município, dois moinhos, uma padaria, uma fábrica de torrefação de café e uma fábrica de vinhos. A sinopse 
estatística sobre Foz do Iguaçu, realizada pelo IBGE-PR, no final da década de 1940, indicou que as atividades relacionadas à exploração agrícola e industrial eram as principais fontes de arrecadação do município.

A receita geral do município, em 1948, foi de Cr\$ 272.457,30 (duzentos e setenta e dois mil quatrocentos e cinqüenta e sete cruzeiros e trinta centavos). A maior parte desta receita, aproximadamente $42,8 \%$, era formada por impostos sobre indústrias e profissões Cr\$ 116.756,10. A segunda maior fonte de receita do município era formada pelo imposto cobrado sobre a exploração agrícola e industrial - Cr\$ 39.027,30. Apesar de o IBGE não ter apresentado uma definição precisa sobre o que era indústria, naquela época, é certo que, em sua classificação, a atividade industrial aparecia como desdobramento das atividades primárias: agricultura, pecuária e extrativismo. As indústrias identificadas na sinopse eram indústrias alimentícias e de transformação da madeira.

\subsection{As elites e a construção da memória: o mito do pioneiro.}

Dentre as publicações analisadas, a primeira que elegeu pioneiros como responsáveis pelo surgimento de Foz do Iguaçu foi escrita por Ottília Schimmelpfeng ${ }^{23}$. De um determinado ponto de vista, é simbólico que, no início dos anos de 1970, a primeira publicação dedicada a produzir a memória da cidade tenha sido escrita pela filha do primeiro prefeito de Foz do Iguaçu, Jorge Schimmelpfeng. Afinal, Ottília representava uma das famílias mais tradicionais das elites locais. Mas a importância das narrativas por ela publicadas reside na influência que exerceu sobre todo o trabalho de construção da memória de Foz do Iguaçu, realizado a partir da década de 1970. Em suas narrativas, ela produziu uma 
matriz de compreensão e análise do passado de Foz do Iguaçu, a partir da qual se desenvolveram inúmeras publicações destinadas à produção da memória da cidade.

Ottília recorreu ao arquétipo do pioneiro para construir sua explicação sobre o passado da cidade. Por meio desse arquétipo, dessa figura imaginária, ela desenvolveu uma narrativa histórica que atribuía a esse passado um sentido profundamente implicado e articulado aos interesses dos setores tradicionalmente dominantes, em Foz do Iguaçu. As memórias produzidas por Ottília Schimmelpfeng (1991) narraram a história da cidade como história de seus pioneiros. Não por acaso, ela introduziu suas narrativas históricas sobre Foz do Iguaçu como uma homenagem a seu pai, o primeiro prefeito do município, aquele que, segundo suas próprias palavras, “[...] embalou Foz do Iguaçu no calor de seu afeto e lhe fez brotar, atravéz [sic] de seus esforços, das suas obras, dos seus anseios, seiva de vitalidade para viesse a desabrochar na grandeza de sua privilegiada condição natural.” (SCHIMMELPFENG, 1991, p.18), condicionando a percepção do leitor, em relação à história da cidade, às características e às capacidades pessoais de Jorge Schimmelpfeng.

Nas memórias de Ottília, Jorge Schimmelpfeng foi o precursor dos precursores da cidade, um dos chamados 'pioneiros'. Os pioneiros, segundo as descrições feitas pela autora, seriam homens visionários, capazes de antecipar o futuro de Foz do Iguaçu como "capital do turismo", pois foram eles os primeiros que viram, nas Cataratas do rio Iguaçu, mais que um fenômeno da natureza: enxergaram a vocação da cidade.

Seguindo os passos de Jorge Schimmelpfeng, apareceram, nas narrativas de Ottília, outros pioneiros do turismo, considerados pelas suas obras como agentes do progresso da cidade. Mereceram maior destaque: Frederico Engel, pela iniciativa, em 1915, de construção do primeiro hotel próximo aos saltos, Major José Acylino de Castro e Acácio Pedroso, pelo

\footnotetext{
${ }^{23}$ SCHIMMELPFENG, Ottília. Retrospectos Iguaçuenses: narrativas históricas de Foz do Iguaçu. Foz do
} 
empenho na organização de excursões e visitas de turistas argentinos e brasileiros às Cataratas.

Quando Ottília Schimmelpfeng, publicou, em sua coluna na revista Painel, em 1976, a narrativa intitulada "Pioneiros do Turismo Iguaçuense" 24 , as obras de construção da usina de Itaipu avançavam e já repercutiam na cidade. Tal publicação revelou o principal esforço de articulação, empreendido pelos setores tradicionalmente dominantes, de se vincular à origem dos acontecimentos que definiram a história da cidade. Nesta perspectiva, a história da cidade só poderia ser explicada pela definição de sua origem e de sua vocação, como sintetizou a memorialista em tela, no trecho transcrito abaixo.

Agora que Foz do Iguaçu está quase atingindo a meta das velhas aspirações, já galgando os últimos degraus que a levam a repousar nas regiões de 'Capital do turismo', quero relembrar os primeiros passos para esta escalada, tão árdua quanto a responsabilidade que impõe à soberania da posição conquistada. Neste quadro do passado vejo a figura do meu saudoso Pai. Jorge Schimmelpfeng, o primeiro a se lançar na arena dos empreendimentos em favor do turismo, nesta cidade. Direta ou indiretamente, ele foi a viga mestra no arcabouço desta grande obra. (SCHIMMELPFENG, 1991, p.27).

Nessa direção, essa matriz buscou definir, também, a identidade da cidade, por meio da evocação legitimadora de um passado repleto sinais e evidências capazes de revelar o turismo como vocação unívoca da cidade. Assim, o pioneiro e o turismo apresentam-se, em alguma medida, como uma antítese, uma antinomia aos planos dos tecnocratas, bem como ao que representa a obra da hidrelétrica. Nesta forma de contar a história da cidade, Ottília Schimmelpfeng produziu uma matriz de compreensão e análise do passado de Foz do Iguaçu, adotada pelos grupos historicamente hegemônicos, que se empenharam na construção da

Iguaçu: Tezza, 1991.

${ }^{24}$ Essa narrativa intitulada "Pioneiros do Turismo" foi dividida em vários capítulos, publicados na Coluna Ottília Schimmelpfeng, em consecutivas edições da revista Painel, no ano de 1976. 
memória da cidade. Esses grupos buscaram definir o sentido do passado de Foz do Iguaçu no desenvolvimento do turismo proposto pelos pioneiros.

Essa matriz se caracterizou pelo compromisso de valorizar a presença daqueles denominados 'pioneiros', fundadores não apenas da cidade, mas do turismo. Esta perspectiva desenvolvida pela citada escritora pode ser identificada em descrições como: "Não fugia à visão de meu Pai [sic] quando aqui se estabeleceu, o vasto campo para a implantação do turismo, em face daquele maravilhoso espetáculo dos saltos do Iguaçu (Santa Maria) e, além, o de Sete Quedas, dádivas que a natureza fartamente distribuíra a esta região do nosso estado." (SCHIMMELPFENG, 1991, p.28). Os pioneiros seriam deste ponto de vista, visionários, porque eram capazes de perceber, naquelas terras distantes do sertão paranaense, não apenas um grande espetáculo da natureza, representado pelas cataratas, mas o caminho para o progresso. Nos relatos de Ottília Schimmelpfeng, a história da origem de Foz do Iguaçu foi escrita como a história de seus fundadores, descritos não apenas como os primeiros mandatários, mas também como precursores do turismo.

Em certa medida, nestes relatos, a origem da cidade foi vinculada ao início do turismo, como se nesta atividade se explicasse a razão de criação e existência daquela. $\mathrm{O}$ mito do pioneiro articula-se à outra construção igualmente mítica da gente da terra, na perspectiva de estabelecer uma forte identificação entre o pioneiro e a cidade, de modo a não mais poder distinguí-los. Assim, o que era interesse de um grupo passava a ser a vocação da cidade. Isso valoriza, ainda mais, o papel de seus fundadores, uma vez que estes eram identificados como precursores do turismo, na cidade. Para explicitar o valor desta gente da terra, as narrativas feitas por Ottília procuravam identificar a região da Foz do Iguaçu como um espaço vazio, em termos culturais e populacionais, preenchido apenas por uma natureza exuberante, que, justamente por isso, merecia ser transformado, como ilustra o excerto abaixo. 
Tenho deslumbrante visão das Cataratas para emoldurar o quadro que retrata a expressiva paisagem de minha terra! $O$ seu contorno é delineado pelo inestimável tesouro que a natureza lhe dotou: um solo fértil e rico; um clima salubérrimo e uma bela situação geográfica, valiosa obra prima para edificar um grande centro de civilização. Necessita, para aperfeiçoar-lhe a forma e o colorido, apenas, mão hábil e capaz de construir, com estes elementos, a obra de arte que irá enriquecer a vasta galeria de nossa Pátria, pois Foz do Iguaçu é uma célula viva que deve crescer e se desenvolver para integrar-se no corpo gigantesco na Nação Brasileira, como parcela viva! (SCHIMMELPFENG, 1991, p. 13-14).

Na década de 1970, a revista Painel destacou-se, nesse trabalho de produção e divulgação da memória da cidade de Foz do Iguaçu, seguindo a matriz esboçada por Ottília Schimmelpfeng, não só por ter aberto espaço para que a mesma republicasse suas narrativas, mas, também, porque publicou artigos dedicados a narrar a história da cidade a partir dos chamados pioneiros. Em 1976, essa revista publicou uma reportagem sobre Acácio Pedroso, apresentando-o como signatário da ata de fundação do município, em 1914, como seu exprefeito, durante o período de 1943 e 1945, e como pioneiro de destacada importância para aquela história: "O pioneiro octagenário é considerado como 'imperecível patrimônio na história de Foz do Iguaçu', e falou para a reportagem da Painel algumas e significativas passagens que o destacaram-no no contexto histórico do município.” (PAINEL, n.27, p.12). Já na apresentação, onde a reportagem buscou justificar a importância de Acácio Pedroso dizendo "Poucos da atual geração iguaçuense sabem quem foi ACÁCIO PEDROSO", transparecia, também, o esforço de construção do pioneiro como ator principal da história local, que deveria se lembrado e valorizado, no presente. Acácio Pedroso, por exemplo, foi descrito pela reportagem da revista mencionada como homem exemplar, patriota e comprometido com a difícil tarefa de desenvolver o turismo, em Foz do Iguaçu. Na reportagem publicada por Painel, em 1978, a história do início do turismo local se confundia com a história de Frederico Engel, pois toda a matéria foi dedicada a narrar e identificar seus feitos como dono de hotel e homem dedicado à atividade turística, como deixam transparecer alguns trechos iniciais da matéria. 
O brasileiro Frederico Engel, labutava com um estabelecimento hoteleiro em Posadas - Missiones Argentina [...] Naquele Tempo, idos de 1915, [...] passou pelo hotel de Frederico Engel, o coronel Jorge Schimmelpfeng, chefe do executivo Municipal [...] Na oportunidade, incentivou a Engel, para que ele se estabelecesse com um hotel na Villa do Iguassú [...] O modesto hoteleiro não demorou muito [...] como grande organizador, Frederico Engel tratou logo de conseguir instalar-se próximo aos saltos. [...] Desde então Engel largou-se de corpo e alma, no serviço [...] Em verdade, Engel foi o primeiro a promover o turismo nesta importante região do oeste paranaense, e enfrentando os percalços e sacrifícios [...]. (PAINEL, n.53, p.7-8).

Coerente com imagem do herói, altruísta e persistente, Frederico Engel foi descrito, pela reportagem, como um "grande organizador" que prevaleceu diante de uma realidade adversa, onde "tudo era moroso e sacrificado". A imagem do pioneiro se confunde com a imagem de um mito, de um herói, porque ele foi descrito, invariavelmente, como altruísta, corajoso, persistente e resistente diante das adversidades, lutando sempre pelo progresso da cidade, como ilustra esta passagem da matéria:

Para conservação daquela estrada, feita pelos métodos mais antiquados, bem como para manter limpo e sempre pronto a receber hóspedes no hotel improvisado, o pioneiro Engel não poupou esforços nem sacrifícios. Tampouco esmoreceu, e a sua coragem e firme determinação lograram com que ele permanecesse fiel ao espírito de pioneirismo. (PAINEL, n. 53, p.7-8).

$\mathrm{O}$ arquétipo do pioneiro produzido a partir das memórias de Ottília Schimmelpfeng (1991) se definia pelo espírito patriótico e visionário, mas alturísta, pois, em suas palavras, "O desejo que se imprimia no espírito dos precursores do movimento turístico em Foz do Iguaçu era mais uma expressão de patriotismo do que as vantagens econômicas que pudessem advir de sua atividade." (p.28).

Nesse trabalho de construção da memória da cidade e explicação do passado, Ottília elaborou e forjou os elementos de valorização das elites locais diante do poder do governo federal, representado pelos tecnocratas encarregados da construção da hidrelétrica de Itaipu. 
Fez isso, opondo-lhe uma tradição de homens identificados como pioneiros. Todo esse esforço de legitimação dos grupos locais, para a construção de uma memória de conquistas e de sacrifícios mediados por uma ação civilizatória, se assemelha muito às práticas das oligarquias locais, durante o domínio colonial português, no Brasil, que reagia às interferências da metrópole , como observou Bicalho (1998, p.271), por meio de

[...] um discurso que valorizava como numa gesta medieval sua condição de heróis e mártires na aventura conquistadora e colonizadora da América [...] os colonos ancoravam-se num 'patrimônio memorialístico' de enfrentamentos, privações, perdas e empenho de suas vidas e cabedais.

Essa matriz explicativa desenvolvida por Ottília Schimmelpfeng (1991) não continha, propriamente, nenhuma novidade, em termos históricos. Ao contrário, tratava-se de uma fórmula bastante conhecida de compreensão histórica, baseada no princípio de que o presente pode ser explicado pelo passado. Uma "formulação esquemática", como sugeriu Raquel Glezer (1992). Na estruturação deste tipo de bibliografia sobre a cidade, a qual conhecemos como "o mito das origens", geralmente o memorialista recorre a determinado personagem, cuja importância atribuída é de protagonista, num processo bastante parecido com aquele descrito por Raquel Glezer (1992, p.11), “como se cada um dos presumíveis fundadores deixasse seus traços de personalidade na própria cidade. A figura do pai fundador se explicitaria na trajetória da cidade, nos seus propósitos, nos seus projetos [...]”. As narrativas de Ottília trilharam esse mesmo caminho, definindo a origem de Foz do Iguaçu, no processo de formação do município, pelas ações de seus mandatários locais e tomando seus projetos e interesses como sendo os da própria cidade.

Por meio do arquétipo do pioneiro Ottília Schimmelpfeng (1991) produziu uma memória da cidade que silenciou a voz de outros sujeitos, como os trabalhadores e as 
populações nativas, existentes na região. Em suas narrativas, não houve lugar para a história dos homens que desmataram os campos, que carregaram e alinharam as pedras na construção das estradas, dos carpinteiros e pedreiros que construíram as pontes e os hotéis, das lavadeiras e cozinheiras e outros tantos trabalhadores, cuja labuta também foi importante para a formação da cidade de Foz do Iguaçu. Ao mesmo tempo, esse silêncio sobre todas essas pessoas contribuiu para construir uma história homogênea e ausente de conflitos e contradições sociais. Ottília expressou essa percepção homogeneizante, de maneira ainda mais direta, durante uma entrevista, na qual ela comentou a natureza 'pacífica e democrática' das relações sociais, em Foz do Iguaçu, como segue no trecho transcrito abaixo.

[...] As relações sociais eram com todo mundo, desde que fossem pessoas corretas, honestas. Não havia muita distinção de preconceitos. Preconceitos sociais não havia em Foz do Iguaçu. Havia naturalmente certos círculos mais chegados, mais homogêneos. Mas, em geral não se fazia separação de classes, nem de camadas sociais. Havia os bem simples na vida social de Foz do Iguaçu. Naquele tempo, não havia clube. As reuniões eram em casas de família. Aí então iam todos. Todos se relacionavam. Do chefe da repartição até o funcionário mais simples, freqüentavam a casa. Se era da Coletoria ou da Mesa de Rendas, ia até o marinheiro. Até ele freqüientava a casa. Então não havia essas separações sociais. Havia congraçamento, de acordo com o tamanho do lugar. Era uma coisa que se notava. (SCHIMMELPFENG apud WACHOWICZ, 1982, p.3940).

A influência dessa memória homogeneizadora formou uma matriz de compreensão e explicação do passado de Foz do Iguaçu tão influente, ao ponto de ser reproduzida como história, nos livros didáticos do primeiro ciclo do ensino fundamental, onde é ensinada a história do município (SANTOS; FRIZON; OLIVEIRA, 1993). Nestes livros, a história da cidade transforma-se numa longa trajetória para realizar sua vocação de cidade turística. Não por acaso, o primeiro assunto neles tratado é a chegada de Cabeza de Vaca às Cataratas, e a conclusão é a consolidação de Foz do Iguaçu como um importante centro turístico brasileiro; e como protagonistas dessa história, os livros destacam os pioneiros do turismo. 
A partir dessa matriz de defesa da importância do pioneiro e do turismo, desenvolveram-se inúmeras publicações que se apresentam como fontes de preservação do passado de Foz do Iguaçu. Até o final da década de 1970, os pioneiros de Foz do Iguaçu foram aqueles nomeados e destacados, primeiramente, pelas memórias de Ottília Schimmepfeng; mas, no início de década de 1980, houve uma ampliação do grupo considerado pioneiro da cidade de Foz do Iguaçu.

Nesse trabalho de construção da memória de Foz do Iguaçu, prevaleceu o esforço de sublinhar o papel e o significado dos pioneiros, não só pelo destaque à sua trajetória de vida, mas pela articulação desta trajetória com a história da própria cidade. Deste ponto de vista, contar a história dos pioneiros significava contar, também, a história da cidade, a exemplo das narrativas sobre Foz do Iguaçu, publicadas por Ottília Schimmelpfeng (1991): em Retrospectos Iguaçuenses, esta autora apresenta a história da cidade a partir de descrições da vida do primeiro prefeito, do primeiro dono de hotel, dos primeiros organizadores do turismo. O alargamento do grupo considerado pioneiro foi, acima de tudo, um exercício de associação de alguns empresários e políticos à tradição criada pelas narrativas da referida memorialista.

Desde o seu primeiro exemplar, publicado em julho de 1982, a revista Memória de Foz do Iguaçu apresentou, como linha editorial, uma preocupação com o passado da cidade e com a valorização dos pioneiros. Nos editoriais das duas primeiras edições, a revista criticou o excessivo valor do presente e dos efeitos do progresso na vida da cidade, responsáveis, em certa medida, por uma amnésia histórica e pela destruição de monumentos do passado. Noutra direção, a revista chamou atenção para as obras e para a história dos homens, os reais pioneiros, heróis que abriram o caminho para que Foz do Iguaçu se tornasse uma grande cidade turística, como sintetizam estes trechos de editoriais da revista. 
O trabalho que aqui apresentamos ao público por ocasião do $68^{\circ}$ aniversário de emancipação política e administrativa do Município, pretende ser, apesar de modesto, um esboço do quanto a comunidade de agora recebeu do heroísmo e da capacidade dos que a precederam nesta terra privilegiada [...]. (BRASIL, junho 1982, p.4)

Este trabalho de pesquisa, humilde, que tem sido feito através da primeira edição, e agora seis meses após a segunda tem a finalidade embora com muitas dificuldades em todos os sentidos, procurar preservar os princípios da história da cidade de Foz do Iguaçu. [...] Quando um município perde o sentimento de continuidade histórica, que outra coisa pode erguer-se a sua frente ao defrontarse com o futuro, senão o vácuo? A REVISTA MEMÓRIA DE FOZ DO IGUAÇU', nas pessoas de seus diretores [...] desabafaram 'Foz do Iguaçu, hoje estrela de primeira grandeza no calendário turístico nacional gerando uma fonte de receita respeitável. Mas está correndo sério risco de transformar-se em uma metrópole historicamente desmemoriada. E isto porque as instituições culturais destinadas a preservar o seu patrimônio artístico e histórico, a guardar a presença viva de tudo quanto os REAIS Pioneiros fizeram, com engenho e arte, para converter e edificar a continuidade fértil de suas sementes entraram, em pleno processo de desintegração. $O$ 'progresso' na sua decantada irreversibilidade derruba a primeira cadeia pública, o prédio onde funcionou a primeira prefeitura construída no início deste século, destrói a Cia Mate Laranjeira empresa que foi fundamental importância econômica no Ciclo da erva mate. (BRASIL, dez.1983, p.3).

Esses dois editoriais, pela contundência de suas afirmações sobre a necessária preservação e recuperação do passado e dos princípios históricos de Foz do Iguaçu, revelaram um esforço da revista em valorizar as elites tradicionais da cidade como os seus reais pioneiros, como os seus primeiros construtores. Sua crítica ao "progresso" lamenta, principalmente, o seu efeito destruidor da memória desses pioneiros, apagada, por exemplo, pelas demolições dos prédios antigos da cidade, como a cadeia, a prefeitura e da Cia Mate Laranjeira, símbolos de seu poder e importância.

Por trás dessa crítica ao "progresso", estes editoriais escondem outra tensão: a disputa dessas elites locais pelo controle dos processos de mudanças, na cidade, iniciados desde a construção da Itaipu. O problema não era, portanto, o "progresso e sua decantada irreversibilidade", mas por quem e como ele era produzido. As elites locais sentiam que o controle da cidade escapava-lhes por entre os dedos. O governo federal decidiu construir a 
usina sem mesmo considerar os interesses das mesmas, abrindo um precedente para uma contínua intervenção dos tecnocratas nas decisões e no poder de mando local.

Dentro desse contexto, a revista Memória... foi um importante veículo de pesquisa, formulação e divulgação dessa memória da cidade, que se confundia com a memória de seus fundadores. Na primeira das três edições, publicadas entre os anos de 1982 e 1983, a citada revista tratou de reafirmar a importância das classes dirigentes locais no presente, destacando a história de organizações como a Associação Comercial e Industrial de Foz do Iguaçu (ACIFI), a Cia Melhoramento Cataratas do Iguaçu, o Oeste Paraná Clube, o Country Clube, o Rotary Clube e o Foz do Iguaçu Country Clube ${ }^{25}$, e o papel que tiveram, no desenvolvimento da cidade

Ao recuperar a importância destas organizações, a revista produzia a imagem de uma elite local, atuante e com raízes profundas, na história de desenvolvimento de Foz do Iguaçu, realçando-lhe o valor como lideranças legítimas da cidade. Simultaneamente, a revista incorporou ao grupo dos pioneiros novos nomes, novas gerações, que não estavam presentes, nos primeiros anos da fundação da cidade, mas que foram destacados pelo seu papel na criação ou na continuidade dessas organizações da classe dominante.

Surgiram outros nomes, como José Acylino (MEMÓRIA..., jun.1982, p.23), considerado um pioneiro, pois, além de fundador do Lions Clube, foi administrador da primeira agência de turismo e fundador da primeira rádio da cidade. Houve aqueles que foram destacados como pioneiros, em função de sua ousadia, como no caso de Etelvino Salvatti, caracterizado pela revista como "[...] um homem que acreditou no futuro da cidade [...]”, pois nesta construiu o primeiro hotel de grande porte. Em outros casos, os pioneiros não são 
apenas os fundadores, os precursores, mas também aqueles que venceram, como no caso do destaque feito a Pedro Basso. Segundo a matéria publicada pela revista Memória..., tratava-se de um imigrante italiano que chegou à Foz do Iguaçu, na década de 1930, "Já bastante conhecido pelo seu esforço e trabalho árduo de pioneiro [...]", homenageado com o título de "Cidadão Honorário de Foz do Iguaçu”, em 1971. Seu filho foi presidente da Câmara de Vereadores, por três vezes consecutivas (MEMÓRIA..., jun.1982, p.42). Se, para a família Basso, a revista associou o pioneirismo à honradez da formação familiar e ao sucesso político (MEMÓRIA..., abr. 1983, p.3), no caso da família Rafagnin, o pioneirismo se tornou sinônimo de uma história de sucesso econômico. Segundo a mesma revista, foi seu "espírito pioneiro de sempre” que levou a família Rafagnin para Foz do Iguaçu em 1961, e lhe garantiu por meio do trabalho honesto e penoso construir uma grande empresa formada por uma rede de hotéis e restaurantes na cidade (MEMÓRIA..., dez. 1982, p.13).

A revista Memória de Foz do Iguaçu, porém, não passou das três primeiras edições, apesar de seu propósito de converter-se em num espaço de registro histórico, em favor da preservação da história e da memória local, como foi proposto pelo seu editor, Saulo Martinho Brasil, e ao associar o trabalho da revista ao de uma casa de memória: "Daqui para frente usaremos o Slogan utilizado pela Casa da Memória de Curitiba 'Casa Romário Martins', Não jogue fora seu passado, traga que a gente PUBLICA.” (MEMÓRIA..., dez. 1982, p.3). A publicação da revista sobreviveu, por apenas dois anos, de 1982 a 1983.

Mas essa perspectiva de relação com o passado de Foz do Iguaçu não se perdeu, completamente, com o fim da publicação da revista Memória de Foz do Iguaçu. Três anos depois, um novo projeto de resgate da memória da cidade começava a ser pensado, por um

\footnotetext{
${ }^{25}$ Foram publicados quatro artigos na revista, no seu primeiro número, em junho de 1982: "CIA Melhoramentos Cataratas do Iguaçu” (p.5); “ACIFI - 32 anos de Batalhas" (p.6), "Oeste Paraná Clube” (p.37) e " 28.5.1961: nasce o Foz do Iguaçu Country Clube” (p.46).
} 
grupo ligado ao Partido do Movimento Democrático Brasileiro (PMDB), que conquistara a Prefeitura de Foz do Iguaçu, nas eleições de 1985.

No primeiro ano da gestão de Dobrandino Gustavo Silva, a Fundação Cultural de Foz do Iguaçu, uma autarquia criada, em 1985 (FOZ DO IGUAÇU, 1985), pelo governo municipal, que substituía o Departamento de Cultura, apresentou em seu Plano de Ação um projeto cuja proposta era de "resgatar a memória da cidade, através de depoimentos de seus pioneiros". (ALENCAR, 1994, p.2).

A retomada do trabalho de construção da memória da cidade foi realizada por setores da classe dominante local, críticos à ditadura, à ingerência e intervenção do governo federal, consubstanciadas nas ações da Itaipu, na cidade de Foz do Iguaçu. Sua iniciativa em produzir a memória da cidade significava, também, reafirmar a força e legitimidade desse grupo da classe dirigente local, articulado em torno do PMDB, não só porque fora eleito democraticamente, mas porque era "da terra". E, neste sentido, "ser da terra" era mais um dos elementos que formava o arquétipo do pioneiro, o que não queria dizer, necessariamente, ser nascido em Foz do Iguaçu, mas pertencer ou ser herdeiro daquele grupo de homens e mulheres que aceitaram o fardo civilizador e enfrentaram e ocuparam o sertão.

Esse passado constituiu-se no argumento fundamental de legitimação, para esses grupos da elite local, contra a presença exógena da Itaipu. Essa disputa aparece um pouco mais explicitada, na descrição das eleições de 1985, feita pelo ex-prefeito de Foz do Iguaçu, Perci Lima, na qual ele enfatiza o fato de que o candidato do Partido Democrático Social (PDS) era um representante da Itaipu, como registra o trecho abaixo.

Iniciava-se o ano de 1986 com ar da liberdade, pois a ditadura acabara e a euforia tinha tomado conta da cidade com a vitória de Dobrandino Gustavo da Silva, do PMDB sobre o preposto da Itaipu, o ex-deputado Tércio Alves de Albuquerque, do PDS e aos candidatos do PDT, o advogado Álvaro W. de 
Albuquerque, do PFL, Ozires Santos e do PT, Raimundo Nonato. (LIMA, 2001, p.114).

O núcleo intelectual responsável pela elaboração e pelo desenvolvimento desse projeto de resgate da memória da cidade, apoiado no arquétipo do pioneiro, era formado por jovens jornalistas e editores de Foz do Iguaçu ${ }^{26}$. Alguns deles foram, até o final dos anos de 1980, proprietários do jornal Nosso Tempo ${ }^{27}$, um semanário local, conhecido por sua linha editorial crítica ao regime militar. Aliás, esse jornal já publicava entrevistas com os chamados pioneiros iguaçuences, desde $1980^{28}$, antes mesmo da apresentação formal do projeto feita por Silvio Campana, em 1986, no primeiro mandato do peemedebista Dobrandino Gustavo da Silva. Porém, apesar de a proposta ter sido apresentada, em 1986, sua realização se deu, somente, a partir do segundo mandato de Dobrandino Gustavo da Silva, iniciado em 1993. A Fundação Cultural apresentou essa proposta como 'Projeto Memória', cujo objetivo era produzir um álbum com a memória de "80 pioneiros iguaçuenses", para ser publicado na semana do $80^{\circ}$ aniversário da cidade.

As entrevistas foram realizadas e publicadas, entre os anos de 1991 e 1994 pelo jornal Gazeta do Iguaçu, à frente do qual estavam os mesmo jornalistas que criaram o jornal Nosso Tempo. Em junho de 1994, a prefeitura comemorou o $80^{\circ}$ aniversário da cidade, com a publicação do Projeto Memória: volume I, reunindo 40 entrevistas, duas realizadas pelo jornal Nosso Tempo, em 1981, e 38, pelo jornal Gazeta do Iguaçu, entre os anos de 1993 e

\footnotetext{
${ }^{26}$ Não é possível dizer ao certo se os nomes identificados na documentação analisada representam todo o grupo do PMDB, mas é possível afirmar que esses jornalistas e editores - Juvêncio Mazzarolo, Aluízio Palmar, João Adelino de Souza, Silvio Campana, Francisco Alencar - formavam um núcleo de elaboração política que teve influência suficiente, nos anos de 1980 e 1990, para garantir a publicação e a divulgação de um conjunto de memórias dos chamados pioneiros da cidade, apresentadas como a verdadeira história de Foz, porque estava baseada na vida de gente da terra, daqueles que construíram a cidade.

${ }^{27}$ Os proprietários, jornalistas e editores do jornal Nosso tempo eram Juvêncio Mazzarolo, Aluízio Palmar, João Adelino de Souza.
} 
1994. A concretização do projeto de entrevistar os 80 Pioneiros só ocorreu, em 1997, quando o poder público municipal publicou, sob título Foz do Iguaçu: Retratos, um livro reunindo todas as entrevistas feitas, tanto as publicadas no Projeto Memória: volume1 e quanto as outras, realizadas entre 1994 e 1997, pelo jornal Gazeta do Iguaçu, além de outras tantas, recolhidas do Guia de Turismo de Foz do Iguaçu, do jornal Correio de Notícias e do jornal

\section{Hoje Foz.}

A publicação destas entrevistas promoveu uma significativa ampliação do grupo dos chamados 'pioneiros da cidade de Foz do Iguaçu'. Aos pioneiros do turismo das narrativas de Ottília Schimmelpfeng foram associados novos nomes como: Rafagnin, Salvatti, José Acylino, entre outros. Mas essa não foi uma ampliação apenas numérica. Foi, também, qualitativa, pois, por meio dela, foi possível destacar outros membros do empresariado local, como Abdul S. Rahal, apresentado como pioneiro da imigração árabe, iniciada a partir dos anos de 1950, que, juntamente com Aníbal Soley, foi apresentado também como precursor do comércio exterior. Por esse caminho, foram destacados, como pioneiros da cidade, outros empresários de 'primeiras iniciativas': a criação da primeira rádio da cidade, da primeira farmácia, do primeiro laboratório, da primeira agência de revenda de carros, da primeira gráfica, do primeiro posto de gasolina, da primeira imobiliária, enfim, destacados pelo seu pioneirismo.

Todavia, nestas publicações - Revista Memória ..., Projeto Memória (vol. 1) e Foz do Iguaçu: retratos -, não havia lugar apenas para os novos representantes do empresariado local. Também aos trabalhadores foi reservado o papel de pioneiros. $\mathrm{O}$ alargamento do grupo de pioneiros, promovido a partir dos anos de 1980, incluiu também a voz desses trabalhadores

\footnotetext{
${ }^{28}$ Entrevistas realizadas e publicadas pelo jornal Nosso Tempo, com Sady Vidal (edição de 10 de dezembro de 1980), Manêncio Martins (edição de 14 de outubro de 1981) e José Werner (1981, edição não informada).
} 
na produção da memória da cidade. Foram publicadas 80 entrevistas, entre as quais 18 foram feitas com trabalhadores considerados pioneiros: o morador mais antigo, a primeira professora, o primeiro marceneiro, o primeiro empreiteiro. Mas as entrevistas apresentam a história de vida dos trabalhadores como um conjunto de fatos pitorescos ou curiosos, como a pergunta feita, recorrentemente, sobre a existência de animais selvagens nos quintais das casas. As dimensões conflituosas das relações sociais locais não foram exploradas. Todos os trabalhadores entrevistados foram tratados como colaboradores, no longo caminho percorrido por Foz do Iguaçu em busca do progresso. Neste sentido, o trabalho de produção da memória, realizado a partir dos anos de 1980, continuou ocultando a memória dos trabalhadores, contudo de um modo diverso do realizado por Ottília Schimmelpfeng, pois o fez integrando-a à memória dominante, como se fosse uma só. Esta questão é das mais importantes.

Em certa medida, podemos dizer que essa atitude foi bastante coerente com a perspectiva política que animava os setores que ocupavam o poder municipal e os órgãos de imprensa, em Foz do Iguaçu. As ações políticas do PMDB eram, naquela época, desenvolvidas a partir da chamada democracia participativa, uma perspectiva de corte socialdemocrata do contexto da década de 1980, que apostou na possibilidade da colaboração entre as classes sociais, pela via da participação popular na administração pública.

Neste capítulo, busquei analisar a dinâmica e as disputas que envolveram o processo de organização de uma memória única que reduziu o passado da cidade à história de sua vocação para o turismo. Contudo, cabe ainda analisar a relação desta memória com a população trabalhadora da cidade, a quem ela também se destinava. 


\section{CAPÍTULO 3.}

\section{Os trabalhadores e a memória dominante.}

Neste terceiro capítulo, tento analisar como se deu a relação entre os trabalhadores e a memória que reduziu o passado de Foz do Iguaçu à história de sua vocação para o turismo.

\subsection{Referências para a discussão.}

Parti do pressuposto de que essa memória elaborada pelas classes dominantes atuou como memória coletiva, nos termos apresentados por Michel Pollak, como uma "operação coletiva dos acontecimentos e das interpretações do passado que se quer salvaguardar" constituindo um quadro comum de referências no âmbito de diferentes coletividades: "partidos, sindicatos, igrejas, aldeias, regiões, clãs, famílias, nações etc.” (POLLAK,1989, p.9). A memória coletiva, é, mais precisamente, para Pollak, um exercício de hegemonia que se traduz como "trabalho de enquadramento da memória". Este trabalho de enquadramento da memória constitui um processo homogenizador, uniformizador das diferenças, excluídas e silenciadas por não corroborarem os elementos de identificação de uma determinada coletividade ou grupo.

Sendo assim, o presente estudo adotou a perspectiva que considera a noção de memória coletiva como memória dominante, como memória oficial. Isso não implicou somente a oposição clássica, expressa pela dominação produzida entre as classes sociais, entre 
o Estado e a sociedade civil, entre o capital e o trabalho. Implicou, num sentido mais amplo, discutir a memória dominante como a memória vencedora, como a memória hegemônica que se consolida no tempo, social e culturalmente, como a memória de todos.

As questões desenvolvidas, ao longo do segundo capítulo, dedicaram-se a analisar como a memória elaborada pelas classes dominantes, a partir dos anos de 1970, formou um quadro de referência comum na interpretação do passado da cidade. O curso da história da cidade, nessa memória, aparece como sendo determinado pela "condição natural” que a define como local privilegiado para a formação de um pólo de turismo nacional. Organizando o tempo e moldando o passado, essa memória, como observou Chesnaux (1995, p.29) constituise em “[...] instrumentos por meio dos quais as classes dirigentes mantêm seu poder”. Essa operação, que reduziu o passado de Foz do Iguaçu à história de uma vocação, garantiu, no presente, a consolidação da imagem da cidade como atração turística nacional.

Contudo, essas conclusões responderam, exclusivamente, a uma análise do processo de elaboração da memória oficial que observou, fundamentalmente, os objetivos das classes dominantes. Faltou, por outro lado, analisar como os trabalhadores recepcionaram esta memória.

Assim, procurei focalizar e problematizar o modo como os trabalhadores articularam idéias, percepções e interesses das classes dominantes às suas próprias memórias. Este processo me pareceu rico e complexo, à medida que os entrevistados, embora concordando com os traços mais gerais da memória oficial sobre a cidade de Foz, indicaram diferenças acerca de sua formação, tanto no que se refere aos critérios para a inclusão dos protagonistas da história da cidade quanto no que diz respeito à "função" principal de Foz do Iguaçu: o turismo. 
Em termos metodológicos, isso significou recorrer à história oral. Assim, por meio da realização de entrevistas, foi possível criar as condições de produção das memórias dos trabalhadores sobre a cidade e de acesso às mesmas. $\mathrm{O}$ manejo dessas fontes orais se inseriu nessa perspectiva, como metodologia privilegiada de investigação da experiência de uma população que, no curso de sua vida, no município, teve pouca ou nenhuma chance de registrar, por meio da palavra impressa, suas memórias e suas visões sobre o passado de Foz do Iguaçu. Tratou-se, portanto, de tentar chegar até as memórias dos grupos não hegemônicos, cuja voz tem sido, em muitas circunstâncias, silenciada pela memória dominante.

Foram realizadas vinte e sete entrevistas com trabalhadores que vivem em Foz do Iguaçu, desde a década de 1970. Cabe ressaltar que as narrativas dos trabalhadores estavam fortemente impregnadas por elementos da memória dominante. Numa primeira análise de seus relatos, percebi que os entrevistados desenvolviam suas narrativas tomando como referência o conteúdo das publicações, organizadas pelos grupos dominantes, sobre a história de Foz do Iguaçu. Estas impressões iniciais me levaram a concluir que os trabalhadores reproduziam, em alguma medida, a memória oficial. As entrevistas revelavam, assim, a força da memória dominante e sua capacidade de constituir um quadro de referências comuns do passado da cidade.

Os mecanismos que garantem a reprodução do discurso dominante pelos trabalhadores podem ser explicados, em grande medida, pela própria lógica das relações sociais características da sociedade capitalista. As classes dominantes dispõem de tempo e quadros muito bem definidos para elaborar, organizar e difundir suas idéias. Pois, como lembrou Dias (2006, p.31):

Para a perpetuação dos saberes dominantes, a questão é facilitada. Seus intelectuais (os únicos que eles reconhecem como tais) passam muito tempo afastados das tarefas imediatas da obtenção da sobrevivência. Passam por um 
processo que Gramsci chama de taylorização do saber e atuam no desenvolvimento do já existente.[...] Para os intelectuais das classes subalternas, o terreno é mais pedregoso. Em geral não podem permanecer tanto tempo na escolarização - taylorização do saber [...] .

Esta explicação ajuda a expor a lógica do processo histórico e social que permitiu à memória da cidade vocacionada para o turismo tornar-se hegemônica. No entanto, essa perspectiva pressupõe uma análise do processo de enquadramento da memória, de cima para baixo, apenas como exercício de dominação. Seus pressupostos limitam a memória dos trabalhadores às fronteiras da memória dominante. Justamente por esta razão, tal explicação não pode ser a única forma adotada para compreensão e análise dos depoimentos dos trabalhadores. Noutra direção, as memórias destes últimos foram tomadas como ponto de partida para analisar os elementos de continuidade e descontinuidade da memória dominante, pois, como sugeriu Pollak (1989, p.12),

\begin{abstract}
Se a análise do trabalho de enquadramento de seus agentes e seus traços materiais é uma chave para estudar, de cima para baixo, como as memórias coletivas são construídas, desconstruídas, o processo inverso, aquele que, com os instrumentos da história oral, parte das memórias individuais, faz aparecerem os limites desse trabalho de enquadramento e, ao mesmo tempo, revela um trabalho psicológico do indivíduo que tende a controlar as feridas, as tensões e contradições entre a imagem oficial do passado e suas lembranças pessoais.
\end{abstract}

Desse modo, inverti a perspectiva de análise dessa relação entre os trabalhadores e a memória dominante da cidade. Caminhei na direção de examinar as memórias dos trabalhadores entrevistados, tomando como referência suas histórias de vida e trabalho, em Foz. Busquei privilegiar a análise dos sentidos e significados por eles construídos e atribuídos à memória oficial da cidade. Esta proposição, entretanto, não deixou de considerar que o conjunto dessas memórias foi produzido num ambiente social de disputa. Isso impôs a observação dos momentos de conflito, de competição entre as memórias para, então, inferir 
sobre as circunstâncias, os temas de confronto e desarticulação, ou de incorporação, aceitação, confluências de interesses entre as memórias dos diferentes sujeitos sociais.

Nesse sentido, o principal objetivo deste terceiro capítulo é analisar de que maneira a memória oficial alcança a memória da cidade apresentada nas entrevistas dos trabalhadores e com ela se articula. Durante o trabalho de entrevista e, posteriormente, de análise das narrativas de vida feitas pelos trabalhadores, dois aspectos da memória dominante se destacaram. O primeiro diz respeito à incorporação do mito pioneiro aos relatos feitos pelos entrevistados. Não é demais lembrar que a construção deste arquétipo foi um dos principais elementos de legitimação política das classes dominantes locais, no processo de construção da memória da cidade. O segundo elemento constitutivo da memória oficial a se destacar, nos relatos dos trabalhadores, foi a idéia da vocação turística da cidade. É sobre isso que procuro falar a seguir.

\subsection{Reivindicando a memória.}

Seguindo a sugestão feita por Pollak (1989), foi possível observar que a incorporação da memória dominante pelos trabalhadores era realizada de maneira contraditória. As formas como estes desenvolviam suas narrativas sobre a cidade, em certa medida, denunciavam a exterioridade da memória dominante.

Ainda que estivessem sendo repetidas por eles, o modo como expressavam e articulavam esta memória dominante às suas indicava que se tratava de um conjunto de idéias que não foram elaboradas por eles. Essa situação foi expressa de maneira mais clara, durante 
uma entrevista realizada com uma trabalhadora aposentada, residente no bairro Jardim Oriente. À medida que explicava as mudanças ocorridas no bairro, ela disse:

"Eu marquei tudo, porque a menina trouxe pra mim o livro. Marquei tudo, a data, tudo: quem que fez, quem que num fez, quem que era prefeito. Deu 43 prefeitos, desde aquela época - 1910. De 1910 pra cá, deu 43 prefeito. O presidente de Câmara Municipal, né? Quem fez a... o... o primeiro prefeito foi Jorge Schimmelpheng. E depois... foi... eu vou trazer o papel." 29

Gesto e fala expressavam o quanto essa memória oficial, organizada a partir de mandatos de prefeitos, não constituía uma parte orgânica de suas experiências e lembranças. Tornou-se lembrança a partir do registro oficial sobre os prefeitos da cidade. Indicavam que aquela memória não tinha sido elaborada por ela, embora tenha julgado ser importante ilustrar a seqüência dos mandatos municipais. Para reproduzi-las, foi necessário recorrer às anotações extraídas do livro escolar de sua neta. Deste ponto de vista, esta exterioridade mostrou os limites do trabalho de enquadramento da memória.

O conteúdo e a linguagem da memória da classe dominante e, ainda, a forma como aqueles são organizados e divulgados não deixam, também, de reafirmar determinadas fronteiras sociais. Por maior que seja a necessidade de legitimação da classe dominante, a pesquisa aqui relatada se realiza de modo a reafirmar a posição subordinada reservada às classes trabalhadoras. Nessa direção, é bastante oportuno lembrar que a memória coletiva atua na formação de um quadro de referência comum, eliminando as contradições e uniformizando a visão sobre o passado. Mas ela atua, também, de modo a definir os respectivos lugares 
sociais de cada grupo, sem apagar as hierarquias e desigualdades sociais, tal como observou Pollak (1989, p.9):

A referência ao passado serve para manter a coesão dos grupos e das instituições que compõem uma sociedade, para definir seu lugar respectivo, sua complementaridade, mas também as oposições irredutíveis.

A análise das entrevistas com os trabalhadores indicou, também, outros limites e contradições do processo de enquadramento da memória. Um deles se refere ao modo como a figura arquetípica do pioneiro, criada pela memória dominante, se articulou às memórias dos entrevistados A maioria destes, principalmente durante o primeiro contato, expressou sensível reconhecimento dos chamados pioneiros de Foz do Iguaçu.

Muitos entrevistados se comportavam com modéstia e diziam que havia gente que sabia mais do passado da cidade. Sugeriam que eu procurasse pelos pioneiros, pelas famílias dos pioneiros, gente importante e antiga do lugar. Não obstante, os trabalhadores aceitaram realizar as entrevistas, e, à medida que desenvolviam suas narrativas sobre a cidade, algumas contradições foram explicitadas $\mathrm{Na}$ fala deles, o pioneiro aparecia como um guardião da memória e da história de Foz.

A inserção do mito do pioneiro no vocabulário dos trabalhadores se deveu, em grande parte, ao fato de que, a partir dos anos de 1980, a memória dominante incorporou novos nomes ao seleto grupo de pioneiros da cidade. Esta ampliação incluiu, também, alguns trabalhadores. Entre os 80 pioneiros destacados pelas publicações oficiais - Foz 80 anos e Foz do Iguaçu: Retratos -, 18 eram trabalhadores. Embora a incorporação destes tenha contribuído para promover uma maior abrangência social da memória dominante, necessária ao seu processo de legitimação, suas histórias, na cidade, não foram destacadas, exclusivamente, em função de sua condição de trabalhadores. Nos livros, sua importância era

\footnotetext{
${ }^{29}$ Entrevista realizada pela autora desta tese com a senhora Militona, em 17 de março de 2007, no bairro Jardim das Flores. Nos casos de citação de entrevistas realizadas por outros autores, estes serão especificamente identificados.
} 
determinada pelo fato de serem moradores antigos, como pode ser observado nestes trechos de entrevistas com pioneiros, publicados no livro Foz do Iguaçu: retratos (FOZ DO IGUAÇU, 1997):

"Numa chácara próxima ao Cemitério Parque Iguaçu, à época residia uma dessas raras pessoas nascidas em Foz do Iguaçu no início do século. Trata-se de Alfredo Mertig, nascido em 1914.” (p.46).

"Quando deu esta entrevista, Manêncio Martins, aos 88 anos de idade, era o morador mais antigo de Foz do Iguaçu, onde havia chegado em 1911." ( p.146).

"Nestas raízes da formação de Foz do Iguaçu, muitos paraguaios têm algo a ver, como é o caso de Pedro Paulo Saucedo, nascido em Vila Rica, Paraguai, em 1906, mas que migrou para o Brasil em 1928 para fazer a vida de laborioso operário" (p.174).

"Quando desta entrevista, em 94, Florentino Correia, era um dos mais antigos moradores de Foz. Nascido em Guaraniaçu em 1901, veio para cá ainda criança com o pai, que trabalhava na linha telegráfica." (p.102).

O modo como os trabalhadores foram apresentados pela memória dominante reforçou a idéia de que sua importância, na história da cidade, residia, fundamentalmente, no fato de serem moradores antigos, ou seja, pioneiros. Suas trajetórias sociais como trabalhadores foram, neste sentido, amalgamada às trajetórias dos grupos dominantes como uma soma de esforços para o progresso e o desenvolvimento de Foz do Iguaçu.

Entretanto, se havia uma sensível aceitação da figura do pioneiro, entre os trabalhadores entrevistados, por outro lado, não havia consenso em relação a quem deveria ser ou não reconhecido como pioneiro. Não houve nenhuma situação de questionamento direto de um nome ou de outro. A questão problemática era o método, o critério de escolha. Nesse sentido, os trabalhadores entrevistados não questionavam a idéia de que, no passado, havia pessoas que deveriam ser lembradas ou homenageadas. O que os trabalhadores reclamavam era o não-reconhecimento de determinadas pessoas, nesse passado. 
A senhora Guilhermina, 68 anos, se identificou como trabalhadora na roça e professora do ensino primário. Durante sua entrevista, ouvi a seguinte reclamação sobre o trabalho de organização da memória da cidade:

\begin{abstract}
"Foram feitos já, algumas coisas; já foi feito um livro que saiu uma vez, mas muita gente ficou de fora, muita gente mais antiga ficou de fora [...], como nossa família mesmo. É... naquele livro, a gente não foi lembrado. E tem pessoas que vieram muitos anos depois e que estão sendo lembrados ali; né? É lógico que, como a gente é uma família, assim, muito, muito... como é que eu vou dizer? A gente não... talvez, não procura sobressair, não entrar, não participar da sociedade. Assim, então, fica mais esquecido [...]". ${ }^{30}$
\end{abstract}

As reflexões feitas pela senhora Guilhermina são indícios fortes de que o processo de reprodução da memória dominante é vivido de maneira tensa por alguns trabalhadores. Ela se baseou nos próprios critérios utilizados pela memória dominante para questionar sua forma de seleção dos pioneiros.

A estratégia, utilizada pelas classes dominantes, de diversificar socialmente o grupo dos pioneiros ampliou a base social de sustentação da memória oficial. Provavelmente, a intenção era fazer com que esta memória conseguisse formar um lastro de identificação entre as diferentes classes sociais da cidade, inclusive os trabalhadores. Contudo, contraditoriamente, essa incorporação do mito do pioneiro serviu para justificar e alimentar a contestação da forma como esta memória foi construída. Nesses termos, dona Guilhermina questionou a ausência dos nomes de famílias antigas da cidade como, por exemplo, a sua.

\footnotetext{
${ }^{30}$ Entrevista com a senhora Guilhermina, em 26 de março de 2007, na cidade de Foz do Iguaçu.
} 
Seus pais chegaram a Foz do Iguaçu, em 1928; no entanto, não foram lembrados como pioneiros.

Durante a entrevista, dona Guilhermina reivindicou o papel de sujeito nesse processo de organização da memória da cidade. Sua atitude mostrou um interesse em fazer daquela entrevista um momento de registro da passagem de sua família pela história da cidade. Atuando como uma guardiã da história de sua família, já nos primeiros minutos da entrevista, ela procurou sintetizá-la, descrevendo e enfatizando a importância de seu pai na constituição do passado de Foz do Iguaçu:

“É, meu pai sempre foi agricultor, mas gostava muito de trabalhar com carpintaria, marcenaria. Ele construiu algumas casas, aqui em Foz; é... pontes. Ele era muito procurado para fazer móveis, assim, armários, guardaroupas, mesas, cadeiras; ele mesmo fazia. E ele também era muito procurado quando morria alguém, porque, naquela época, não tinha ninguém aqui em Foz que... que trabalhasse com caixões de defunto; e então, ele era procurado pra fazer os caixões na época.[...] Então, ele também construía canoas, assim; trabalhava as madeiras, a gente via aquele esforço dele... é... molhar as tábuas, e puxar e retorcer elas, pra ficar no formato da canoa, pra depois, é... construir, daí colar, calafetava, é... com resto de tecidos, pra não entrar água. Então, essas coisas a gente acompanhou muito, viu muito o trabalho do meи pai, nesse sentido, assim, de trabalhar com madeira. E a nossa chácara é ali, onde hoje é o Hotel Carimã, a parte de trás ali, tudo ali, o bosque que tinha ali. Ali eu me criei, andando e brincando, naquele bosque. Também, uma parte dessa terra, ali, meu pai cedeu - 100 metros quadrados - pra prefeitura, na época de 1950, por aí, mais ou menos; ele cedeu pra construir uma nova escola. Porque como a escola funcionava bem ali, onde é o Hotel, hoje... ali, era a escolinha, de madeira; e era um antigo curtume, que ficava meio pendido sobre o Rio Carimã”. 
A senhora Guilhermina acreditava que sua família pertencia a este grupo de pioneiros, que trabalhou para o desenvolvimento da cidade: "E a gente tá contente, assim, de... de saber que a gente foi, assim, uma pessoa que... de família, que... uma família que trabalhou a vida inteira pelo crescimento dessa... dessa cidade.". Trabalhando na construção de casas, de pontes, na fabricação de móveis; foi assim que, para dona Guilhermina, seu pai contribuiu para o crescimento da cidade.

Porém, os feitos de seu pai teriam sido apagados pelas construções em alvenaria que substituíram as casas e as pontes de madeira. E lembrar desse tempo não é tarefa fácil para dona Guilhermina, já que muitos suportes dessa memória se desfizeram, com o próprio tempo. Sua história conta apenas com as lembranças que teimam em escapar até mesmo para a mais dedicada guardiã de seu legado. Nem mesmo essa senhora conseguiu se lembrar da localização das construções das quais seu pai participou, como pode ser observado nesta passagem transcrita da entrevista:

\footnotetext{
"Eu sempre digo é... infelizmente, hoje em dia, é... de repente, se a gente procurasse, saísse, ver bem, analisasse bem com a família, quais as casas que meu pai construiu, ali na cidade, de repente, a gente até acharia mais alguma. Mas antigamente, eu lembro que passava assim: ah, essa casa aqui foi o papai que fez; ah, essa casa aqui foi o papai que construiu. A gente tinha aquele orgulho de saber que a gente tava andando num lugar onde tinha as coisas que - né? -, que o pai da gente tinha ajudado fazer."
}

Esta entrevista não foi a primeira nem a única oportunidade em que a senhora Guilhermina se envolveu na busca pelo reconhecimento de seu pai, como pioneiro. Ela lutou, também sem sucesso, para que a escola construída no terreno doado por seu pai levasse nome 
dele. Depois de ter insistido, por vários anos, a rua onde está localizada a escola passou a levar o nome do pai de dona Guilhermina. Mas, para ela, embora isto tenha sido uma conquista, não representava a justa vinculação do nome de seu pai às iniciativas em favor da educação, no município. Por isso, ela usou a entrevista, mais uma vez, para mostrar seu descontentamento, mas, acima de tudo, para homenagear seu pai, como ela acreditava que ele merecia:

\begin{abstract}
"Eu tenho um sentimento comigo. Eu vou expressar isso, agora, porque eu tentei diversas vezes, com... na Prefeitura, na Secretaria de Educação, que a escola levasse o nome do meu pai, como foi ele que doou o terreno; e ele sempre foi muito, muito preocupado pelo ensino, pela educação das famílias, e ele doou esse terreno pensando no... né? Então... mas a gente não conseguiu. Então, eu sinto isso aí, é... consegui agora, há dois, há três anos atrás, que fosse, pelo menos, colocado o nome da rua que passa em frente do colégio. Tá com o nome do meu pai, agora, que é Martin Níveron. Mas, a escola mesmo, a gente não conseguiu."
\end{abstract}

Esta percepção do tratamento desigual reservado aos trabalhadores apareceu também na entrevista com o senhor $\operatorname{Carlos}^{31}$, cujo pai foi um dos trabalhadores identificado pela memória dominante como “[...] uma destas raras pessoas nascidas em Foz do Iguaçu no início do século [...]"(FOZ DO IGUAÇU, 1997, p.46). A questão foi abordada pelo senhor Carlos, justamente, quando ele descrevia como eram as relações sociais, na cidade, à época de sua juventude:

"Ah, o pessoal não gostava de se misturar. Portanto, que quando alguma pessoa de nível mais alto - né? -, mais privilegiado - né? -, dava atenção pra gente ou tratava a gente com delicadeza - né? -, a gente se admirava - né?

\footnotetext{
${ }^{31}$ Entrevista com o senhor Carlos, em 27 de março de 2007, na cidade de Foz do Iguaçu.
} 
-, porque geralmente eles queriam ser mais do que os outros - né? -, por causa que tinha mais recurso, e... né? -, isso aí existia."

Em certa medida, essa avaliação feita pelo senhor Carlos sugere os limites de atuação da memória dominante entre os trabalhadores. Pois ela não foi capaz de apagar completamente da memória dele o sentimento de que havia um tratamento desigual, dirigido aos trabalhadores. Nesta passagem da entrevista, as lembranças do senhor Carlos expuseram como ele viveu e sentiu as diferenças sociais, ao longo de sua vida na cidade. Contudo, ao ser indagado sobre como identificava tal diferença, sua memória refez o desenho do passado:

"Mais dinheiro, mais estudo, já vinha de outros lugares, já feito, porque não é pessoas que se fez aqui. Porque vê, uma boa parte das pessoas que, até hoje, se diz pioneiro nem nasceu aqui, já... nem sempre... Mas tem muitos deles que até aventureiro é, e depois, empinava o narizné? -, uns, porque tinha mais dinheiro, outro, porque tinha mais estudo - né? -, então, se achava mais que os outros. Ejá se juntava os seus com os seus. Por exemplo, o filho do rico não era pra se misturar com o filho do pobre, né? Portanto, aquilo que eu tava comentando com você - né? -, do prefeito que era muito popular - né? -, que conversava com qualquer um e alcançava criança nem se interessava saber filho de quem que era - né? Ó, filho, pra onde 'cê vai? Né? Disse: eu vou até tal parte. Entra aqui. Junto com os filhos dele. Uma pessoa que foi muito bem quista."

Seu primeiro esforço para recordar as relações sociais, na cidade, o conduziu a uma definição acerca do pioneiro, que exclui pessoas ricas, de posses, que se diferenciavam propositalmente de outras, por conta do dinheiro ou da escolaridade que tinham. Tal imagem, relativamente simples, apenas separava ricos de pobres. 
Seu segundo esforço de recordar obrigou-o a uma elaboração mais complexa sobre a realidade vivida. Ele teve que acomodar distintas percepções, lembranças e valores acerca do tempo passado na cidade. Primeiramente, manteve a diferença social interpretada como distância entre ricos e pobres. Em seguida, talvez refletindo sobre a insuficiência dessa formulação, devido ao fato de que ela transformara pioneiros ricos em pessoas esnobes, "de nariz empinado", "aventureiros", o senhor Carlos restringiu o tratamento discriminatório às pessoas ricas e bem educadas que "nem nasceram aqui".

Este trabalho da memória levou esse entrevistado a acrescentar outro critério na definição do pioneiro. Havia pioneiros ricos e pobres, educados e iletrados. Entre estes, uma identidade comum pavimentava seus encontros, suas conversas, suas relações, sua vida na cidade. A evidência levantada pela recordação relata um desses encontros, aparentemente inusitados, entre um prefeito e seus filhos com a prole de um trabalhador. O prefeito é mostrado a partir de uma dupla razão: pelo significado do cargo e pela naturalidade. Ele oferece carona aos filhos de outro iguaçuense, nem tanto por algum tipo singular de generosidade, mas por ser da terra. Entre naturais de Foz do Iguaçu, haveria um laço de reconhecimento, uma identidade de pioneiro.

Desse modo, o senhor Carlos buscou pacificar a suposta cisão entre ricos e pobres, na cidade de Foz do Iguaçu, que ele mesmo salientou. Haveria diferenças sociais; haveria discriminação; mas tais situações emanariam daqueles que nem nasceram em Foz. Estes seriam "aventureiros":

“[...] É gente que vem tentar alguma coisa melhor com a inteligência dele, com o estudo que tem - né? -, tirar proveito da situação. Porque tem gente que vem colaborar - né? -, então não é considerado aventureiro." 
Segundo o dicionário Houaiss (2003), o adjetivo "aventureiro" pode ser sinônimo de embusteiro, trapaceiro e oportunista. O senhor Carlos se referia, exatamente, a este significado. Nos termos colocados por ele, ser "aventureiro" representava participar ou representar um grupo de pessoas oportunistas que atuavam na cidade com o propósito de colher vantagens econômicas e sociais. Para o entrevistado em tela, este grupo teria sido, equivocadamente, reconhecido como pioneiro. Um grupo formado por pessoas que, no seu entender, usavam a cidade em favor de seus próprios e exclusivos interesses, sem oferecer, em troca, qualquer contrapartida. Ao recordar do tempo passado e atribuir a discriminação social aos "aventureiros", àqueles que vinham de fora, o senhor Carlos acertava contas com sua memória e a com a própria história da cidade.

Tais recordações podem ser rejeitadas pela própria contradição nelas presente ${ }^{32}$. Contudo, sua relevância está em demonstrar que o trabalho feito pela memória tomou o sentido de salientar a imagem inicial da cidade de Foz - e dos pioneiros - construída pelo senhor Carlos. Coube a ele reparar sua própria fala visando resolver uma equação cujo desenvolvimento esbarrou numa estranha variável. A cidade vivida por ele era matizada de contradições sociais. Mas suas lembranças encontraram uma forma de explicar tais desigualdades reconfigurando seu passado e atribuindo a discriminação aos de fora.

Outro aspecto a ser discutido diz respeito à aproximação entre as interpretações do senhor Carlos e da senhora Guilhermina. Juntos, eles apresentam um padrão sobre o que deve ser recordado acerca do pioneiro: ser nascido em Foz do Iguaçu e ser antigo morador da cidade.

\footnotetext{
${ }^{32}$ Tem razão Alessandro Portelli, quando chama a atenção para o fato de que o trabalho da memória vale pelo próprio esforço de construção do fato e pelas articulações realizadas, muitas vezes contraditórias, com os próprios relatos do entrevistado. No que se refere ao nosso trabalho de dialogar, analisar e interpretar relatos, o que precisa ser identificado é a intenção do entrevistado, isto é, não somente o que ele recorda, mas como ele recorda. (PORTELLI, 1993).
} 
Tais critérios tendem a subordinar quaisquer outros traços de caráter social e econômico, na definição de pioneiro. Apóiam-se, de certa maneira, em alguns dos critérios utilizados e defendidos pelos organizadores da memória oficial, como foi discutido no capítulo anterior. De certo modo, toda vez que foram chamados a falar sobre esse assunto, o senhor Carlos e a senhora Guilhermina ativaram esse mecanismo. E essa questão é uma poderosa chave para compreender os pontos de toque entre memória oficial de Foz organizada e aqueles que, de alguma maneira - ou por alguma razão -, ficaram ou se sentiram fora dela.

Quando os dois entrevistados reafirmam o berço e a longevidade, na cidade, como critério de definição do pioneiro, fazem-no numa perspectiva de se verem incluídos nela. E embora isto seja representativo de outros trabalhadores entrevistados, tal mecanismo se destaca em relação ao senhor Carlos e à senhora Guilhermina pelo fato de que reivindicam inclusão de seus antepassados na memória oficial e atuam, no presente, com este propósito ${ }^{33}$. Portanto, por serem emblemáticos, examinaremos este processo a partir de suas narrativas. Vejamos como isto é feito.

Evitando confundir-se com um "aventureiro", o senhor Carlos sublinhou uma definição de pioneiro, que introduziu um sentido bastante preciso em relação à cidade: aquele que “... vê no que pode ser útil ...".

Esta forma de pensar a cidade e as relações sociais que a definem, elaborada pelo senhor Carlos, parece estar fortemente ancorada na intenção de incorporar as pessoas à cidade, nem tanto pelos que elas têm ou possuem, mas pelo que fizeram, concretamente.

\footnotetext{
${ }^{33}$ Ao lidar com a memória de militantes comunistas de Terni, na Itália, Alessandro Portelli se deparou com um caso semelhante, em que Filliponi, antigo operário e partícipe na resistência ao fascismo, esforçara-se para incluir-se como protagonista na memória oficial do Partido Comunista Italiano. Entrevistado, em 1973, quando tinha 76 anos, Filliponi apresentou-se, por meio de situações imaginárias, como antagonista do Secretário Geral do PCI, Palmiro Togliatti. (PORTELLI, 1993).
} 
Aqui, abre-se uma porta para vinculação dos trabalhadores à história da cidade, já que o senhor Carlos sugere ter sido o trabalho a base para a existência de Foz do Iguaçu.

Durante a entrevista, em todas as oportunidades que teve de falar da família em que foi criado, procurou ele descrevê-la a partir das ocupações de seus membros. Ele buscou identificá-la como um ambiente de pessoas que sempre trabalharam, a começar por seu avô, de origem germânica, que chegou a Foz, por volta da década de 1910, depois de servir ao exército alemão:

\begin{abstract}
"O meu avô [...] trabalhava nos fins de semana, na roça, na chácara, às vezes, até de noite, com lua - né? -, ele trabalhava na roça. Durante o dia, a igreja matriz... esses padres que cuidavam da igreja, ali, eles tinham uma oficina de marcenaria, e o meu avô era marceneiro, e ele trabalhava com eles, lá; inclusive, daqueles banco que tem na igreja matriz, lá tem banco que foi feito pelo meu avô; ele trabalhava lá. Então, durante o dia, ele trabalhava lá; e ás vezes, de noite, com lua, ele ia capinar, e os finais de semana."
\end{abstract}

O fato de começar sua narrativa pelo avô indica uma escala de descendência, cuja razão é demarcar seu início, na cidade, ou seja, sublinhar a origem de uma determinada tradição. O avô chegou para trabalhar. Não era um aventureiro. Isto é esclarecido quando o senhor Carlos diz que, apesar de o avô ter conhecimento de ofício, não se negava a labutar no campo, em atividades, provavelmente, desprestigiadas. Sem medo do trabalho, seu avô dobrava turnos e deixava sua marca na cidade. Sua habilidade em marcenaria atravessou o tempo e pode ainda ser vista, em alguns bancos da Igreja Matriz. Este registro, no entanto, não transborda a própria memória do neto. E talvez, quando ressalta o que fez o avô, o senhor Carlos me mostra onde estão as evidências de sua vida, nos primórdios da cidade. 
Depois do avô, a presença mais marcante é a de sua mãe. Nascida em Foz do Iguaçu, de origem alemã, já era mãe de três filhos, antes de se casar com o pai do senhor Carlos. Ela trabalhou como lavadeira e, por meio dessa ocupação, ajudava no sustento da família. Embora fosse uma atividade desprestigiada, o senhor Carlos estruturou o trabalho da mãe como necessário a muitas autoridades de Foz de Iguaçu.

"Minha mãe lavava roupa, tinha aquele pessoal mais... de mais recurso - né? - e, inclusive, ela lavou, muito tempo, roupa pro primeiro promotor de Foz do Iguaçu, pro doutor Saulo Ferreira - né? -, primeiro promotor de Foz do Iguaçu. Ele usava aqueles terno branco e coisa; então, minha mãe cuidava da roupa dele, né? Tinha também o doutor Heleno Schimmelpfeng, filho do primeiro prefeito de Foz do Iguaçu, né? A mãe cuidava a roupa dele. É... tinha várias pessoas que... minha mãe era procurada pra cuidar das roupas, né? Não é por causa que era a minha mãe, mais, olha, até eu quando, ela cuidava da minha roupa, eu saía todo orgulhoso [risos]; ela era muito procurada, né? Aí, depois, mais tarde, ela foi zeladora do Grupo Bartolomeu Mitre. Ali, ela se aposentou, né?"

O orgulho pelo trabalho da mãe é o primeiro elemento que define o que deve e merece ser lembrado. Para o senhor Carlos, não importava produzir um balanço negativo da trajetória de trabalho de sua mãe, nem questionar as contingências por ela enfrentada, muito embora seu depoimento não escondesse nem subtraísse as dificuldades cruzadas pela família. De maneira diferente, ele aprendera com os pais que as adversidades características de uma família pobre como a sua só poderiam ser enfrentadas com o trabalho.

A narrativa do senhor Carlos sobre sua mãe é, de longe, a mais detalhada. Talvez, isso se explique pelo fato de que pôde observar de perto e por mais tempo o cotidiano da mãe. 
Desde criança, provavelmente, ele conviveu, em casa, com a rotina de trabalho de sua mãe, que lavava e passava roupas para fora. Segundo sua descrição, tratava-se de uma rotina bastante árdua, que sua mãe buscava realizar com esmero e destreza: a água "era puxada na manivela do poço"; a roupa era lavada "no tanque e na esfregadeira”.

Mais do que isso, o senhor Carlos associa, novamente, a presença da mãe - e o que ela fazia, com diligência e desvelo - à história da cidade. As roupas bem lavadas davam a estampa necessária a muitas autoridades de Foz. Além disso, corrobora o que havia dito, antes, sobre as relações entre os ricos e os pobres oriundos de Foz do Iguaçu, à medida que eram as personalidades importantes, como o promotor e o filho do prefeito, que a procuravam, que precisavam do seu trabalho. E no desfecho do relato, o senhor Carlos ressalta a ligação que sua mãe teve com a escola mais antiga e mais famosa da cidade. Havia sido, durante muitos anos, zeladora do Grupo Escolar Bartolomeu Mitre ${ }^{34}$. É assim que a trajetória biográfica de sua mãe é decalcada num monumento da memória oficial.

O mesmo raciocínio desenvolvido pelo senhor Carlos sobre a mãe e o avô é empregado para explicar a participação que seu pai teve na história da cidade. O pai, pedreiro por ofício, foi lembrado junto com o tio, um mestre-de-obras, pelos edifícios que ajudaram a erguer.

"E o meu pai era pedreiro. Meu pai trabalhava de pedreiro e... ele participou de várias obras aqui da cidade, influenciado pelo cunhado dele, que era mestrede-obra. O cunhado dele veio da Alemanha; ele participou da I Guerra Mundial. Depois, quando teve a II Guerra Mundial, ele já estava aqui, em Foz do Iguaçu-

\footnotetext{
${ }^{34}$ Portelli chama a atenção para o fato de que a memória social pode ser manipulada por quem "lembra". No seu dizer, cada indivíduo extrai memórias de uma variedade de grupos e as organiza de forma idiossincrática, de maneira a reforçar sua própria posição no mundo. As intervenções de entrevistados como o senhor Carlos e a senhora Guilhermina assemelham-se a este procedimento em relação à memória, fazendo lembrar situações que os introduzem, e às suas família, na memória oficial de Foz do Iguaçu. (Cf. PORTELLI, 1996).
} 
né? -, e ele era mestre e... os prédio histórico que ainda existe, tem alguns que foi a administração dele - a igreja matriz, a catedral ali - né? -, foi administração dele; o prédio prefeitura, ainda hoje, foi administração dele, e o antigo Hotel Cassino Iguaçu foi administração dele. E meu pai trabalhava junto com ele; ali que ele aprendeu a trabalhar de pedreiro, também."

Como disse, o senhor Carlos segue o padrão criado para reivindicar a presença da família na memória oficial. O tio trabalhou na edificação da Igreja Matriz, e administrou essa obra, um marco importante de Foz. Também, administrou a construção do antigo Hotel Cassino, onde funciona, atualmente, a Delegacia da Polícia Federal. E nessas construções, o pai trabalhava junto.

O padrão assumido na narrativa do senhor Carlos parece estruturar-se pelo trabalho. Cada um a seu modo, todos construíram a cidade como pioneiros. É o que acontece, também, na narrativa apresentada pela senhora Guilhermina. Referindo-se ao seu pai, o trabalho é tomado como valor que justifica a presença de sua família entre os pioneiros. Juntos, o senhor Carlos e dona Guilhermina militam pelas memórias de suas famílias, buscando assegurar, para seus antepassados, recursos da memória oficial que garantam que estes serão lembrados, na história da cidade.

O nome do pai do senhor Carlos ganhou espaço, entre os entrevistados do livro Foz do Iguaçu: Retratos. Como já discuti, anteriormente, seu pai "mereceu" registro, no livro organizado pelas classes dominantes, porque nascera em Foz do Iguaçu e, à época, era um de seus moradores mais antigos. Não fosse esse "detalhe", provavelmente, não seria lembrado pelas classes dominantes. Agora, o senhor Carlos reivindica lembrança "oficial" para seu tio. Quer que o prédio onde existiu o antigo Hotel Cassino leve seu nome. Ironia ou não, além de 
seu tio, o senhor Carlos reivindica que seja lembrado um Hotel que não deixou marcas claras na cidade.

"[...] eu gostaria que fosse lembrado - né? -, até, se eu pudesse, algum dia, eu ia pleitear, embora seja difícil; existe muita burocracia. Eu ia pleitear pela Câmara Municipal, que fosse dado o nome do antigo Hotel Cassino, que não tem nome, que fosse dado o nome dele - né? -, pela passagem dele por ali - né? -, que foi administração dele - né?."

Recorrer ao trabalho como forma legitimadora de inclusão da família entre os pioneiros revela, também, o esforço para registrar, na memória oficial, a presença do trabalho. Afinal, a trajetória do senhor Carlos é toda ela assentada numa escala, cujo valor que organiza sua vida e a de seus descendentes é o trabalho. Aqui, trata-se de um valor positivo recuperado, a despeito da intenção das classes dominantes de consagrar a cidade como fruto do trabalho “empreendedor" e "visionário".

"Olha, era bastante dificultoso, que roupa nova muito difícil de nóis ganhar, ficava... nóis éramos em seis irmãos; um faleceu com 12 anos... daí... Mais nóis éramos em seis, ia passando de um pro outro a roupa, calçado - né? - era conservado. Olha, usava pra sair, voltava e engraxava e guardava, ia passando de um pro outro, e... Tudo se ajudava, dentro do possivel, ajudar a custear a despesa da casa, que era difícil na época. Eu mesmo acho que muitas coisas mudou e mudou pra pior, porque eu trabalho desde os oito anos e não fui prejudicado em nada com isso. E hoje, não querem que os meninos trabalhem, né? É... não digo ser escravizado, né? Mas se tiver ocupado, livra de muitas coisas ruim. Eu não fui prejudicado com isso não; olha, serviu, olha, muito pra minha vida. Eu gostava de vender fruta, verdura... eu saía pra vender - né? - e trazia o dinheirinho e entregava pra minha mãe, pra ajudar a 
custear as despesa de casa, e fui aprendendo e ganhava

dinheiro."

Para o senhor Carlos, tanto quanto para dona Guilhermina, a ética que confere valor ao trabalho é operada numa zona de relativa autonomia, que refaz o sentido que as classes dominantes têm e imprimem ao trabalho. Não se trata de uma ética de fundo calvinista, cujas marcas históricas ajudaram a impor a ordem capitalista (WEBER, 2004), mas uma ética baseada no "trabalho artesanal" (MILLS, 1976), cujo significado ou sentimento de bonificação reside na expectativa do bom trabalho realizado, ou seja, "a qualidade do produto e a arte de fazê-lo" (MILLS, 1976, p.238).

Desse modo, ao reivindicarem a presença de seus familiares na memória oficial, o senhor Carlos e a senhora Guilhermina manobraram, numa região construída pelas classes dominantes, evidenciando o peso e a importância de seus descendentes na história da cidade. Isto pode ser interpretado, também, como uma área de conflito, onde os trabalhadores aceitam as regras do jogo e tentam incluir seus pares a partir delas. De certa maneira, dois entrevistados acima citados exigem um lugar, na memória oficial, recuperando suposto prestígio que eles atribuem aos seus parentes.

Para além de reivindicar a presença de seus familiares na memória oficial, muitos trabalhadores que entrevistei insistiram na reafirmação de determinadas imagens, utilizadas pelas classes dominantes na construção da memória oficial. A principal delas foi o turismo de Foz do Iguaçu. Aparentemente, os entrevistados reconheciam e corroboravam muitas imagens e discursos das classes dominantes acerca da "vocação turística" da cidade. Contudo, dialogando mais profundamente com eles, foi possível perceber diferenças nítidas sobre a idéia de "vocação". É sobre este assunto que trato a seguir. 


\subsection{A vocação turística revisitada.}

Durante as entrevistas, tornou-se lugar comum ouvir os trabalhadores definindo Foz do Iguaçu como cidade turística. Algumas vezes, isso ocorria de maneira espontânea, sem que lhes fosse perguntado. Outras vezes, esta definição da cidade só aparecia, em suas narrativas, quando eu perguntava, diretamente, se consideravam Foz do Iguaçu uma cidade turística e se o turismo era importante.

De qualquer modo, numa ou noutra situação, Foz do Iguaçu aparecia como uma cidade turística, na percepção dos trabalhadores. Esta primeira observação confirmava, portanto, que a fala dos mesmos acabava reproduzindo o discurso da memória dominante da cidade.

Entretanto, concluir que a memória dominante conseguiu tornar-se referência nas narrativas dos trabalhadores sobre a cidade não basta para os objetivos propostos, neste estudo, pois reduzi-las ao exclusivo efeito do enquadramento da memória consubstanciado pelas classes dominantes representa, deste ponto de vista, negar aos trabalhadores a condição de sujeitos sociais. Na perspectiva aqui adotada, as memórias elaboradas pelos trabalhadores sobre a cidade de Foz do Iguaçu só podem ser compreendidas se inseridas na dinâmica contraditória das relações sociais que as forjaram.

Por tudo o que observamos até aqui, o processo de reprodução da memória dominante da cidade foi bastante contraditório. Os trabalhadores legitimaram o mito do pioneiro, mas, também, utilizaram-no para questionar a memória oficial tal como ela foi organizada. Diante disso, procurei trazer para o debate questões sobre como os trabalhadores, por meio de suas narrativas, reconhecem o turismo como uma vocação da cidade de Foz do Iguaçu. 
O senhor João F., 90 anos, agricultor, vê Foz como uma cidade turística. Porém, o turismo, para ele, é algo recente.

\begin{abstract}
"Porque Foz era muito ruinzinha, aqui, nesse tempo que eu vim pra cá [1970], comecei a vida... era tudo em mato. Tinha só o centro ali da avenida Brasil, nem JK [bairro] não existia, que ali o Maracanã [bairro]. Agora, hoje, que cresceu muito, né?",35
\end{abstract}

Embora seus 90 anos tenham já tirado a precisão de ler o tempo, o senhor João Mineiro informa um desenho da cidade onde o turismo era "fraco", e os hotéis e os turistas ganharam forma bem mais tarde:

“[...] Mas agora tem mais [turista], viu? É que aumentou depois da Itaipu [1970], que antes da Itaipu era fraco. Até a estrada pra ir lá nas cataratas não era muito boa. Agora tá, mudou tudo, né? E tem a... é a terra da capital do turismo, que tem a maior hidrelétrica do mundo. E eu conheço a segunda. [...] Acredito que o que dá vida aqui pra Foz é os turista, viu? Que tem dia de ir lá, nas Cataratas, de dar dez, doze mil pessoas, sabe disso, né? Esse hotel daqui é tudo superlotado, que eles tem dinheiro."

Ele reconhece, no dia-a-dia urbano, a presença de muitas pessoas que visitam a cidade, principalmente, pessoas de diversas nacionalidades. Mas adiciona: o turismo se liga à Itaipu Binacional.

"[...] porque, aqui, vem gente de toda parte do Brasil... é... do mundo. Vem do Japão, vem de toda parte do Brasil, né? Vem aqui e deixa muito... Esses hotel aí, quem sustenta é os turista, que os daqui mesmo, né? É só

\footnotetext{
${ }^{35}$ Entrevista com o senhor João F., em 22 de março de 2007, na cidade de Foz do Iguaçu.
} 
os que vem de fora. E tem também outra, que a Itaipu é binacional, é a maior hidrelétrica do mundo e a segunda é Tucuruí, lá onde que eu morei, no Pará, perto de Marabá. Então, a vida é essa. Só que o Pará mesmo teve... tem... teve mesmo... eu saí de lá; eu saí perdendo muito, porque não tinha hidrelétrica. Depois que construiu a Tucuruí, a Transamazônica é toda iluminada, que lá era os... não era luz elétrica, era com motor, movido a óleo, né? Dava muita despesa. Agora... tá uma beleza de se viver, tá uma propriedade que eu tinha lá... tá tudo iluminada agora."

O senhor João F. afirma que o turismo injeta muito dinheiro na economia local, principalmente na rede hoteleira da cidade. Projeta Foz como uma cidade relevante, por sediar Itaipu, mas saca este argumento para comparar e explicar sua própria falta de sorte, noutro lugar que viveu: o Pará. Reclama que trabalhou, nas suas próprias terras, mas que não deu certo. Se lá tivesse uma hidrelétrica, talvez não tivesse que se desfazer de sua propriedade.

Isto se fixou em seu pensamento. Se as despesas com o óleo que movimentava o motor não fossem tão caras, seria um lugar bom de viver. Suas lembranças estão cheias de "se". Está certo de que a construção de Tucuruí, a segunda maior hidrelétrica do Brasil (a maior 100\% brasileira), mudou tudo, no Pará. É esta certeza que o leva a valorizar a cidade de Foz. Quando fala do turismo, associando-o à grandeza de Itaipu, é também de Tucuruí, no seu passado vivido no Pará, de que está falando.

Para o senhor Luis T., 66 anos, agricultor, Foz era uma cidade "pacata", de pouco movimento. O turismo existente era praticado apenas por pessoas que lá moravam.

\footnotetext{
“Era pacata porque era pouco o movimento. $O$ movimento sempre aqui foi mais turístico, mas não com o turismo praticamente vindo de fora - era, praticamente,
} 
de Foz mesmo, porque as cataratas é uma coisa muito bonita, né? Era e é, até hoje. Então, nós temos, aqui, o marco das três fronteira, que também é uma visão muito linda, e então sempre foi meio turística. Agora, depois que abriram a usina de Itaipu, construíram a Ponte da Amizade e depois a Ponte da Fraternidade. Aí sim, aí, Foz cresceu, simultaneamente; foi desenvolvimento pros quatro cantos. Aí, aumentou." 36

Assim como ocorreu com o senhor João F., a memória do senhor Luis é imprecisa, na datação de fatos que julga relevantes para a história da cidade. De maneira mais sintética, ele separa o tempo apenas em passado e presente.

Quando me concedeu esta entrevista, estávamos conversando sobre a mudança da cidade, uma vez que ele insistia em dizer que Foz era uma cidade pacata. Apesar de reconhecê-la como cidade turística, salientando as Cataratas e o Marco das Três Fronteiras ${ }^{37}$, o ponto de inflexão, na história da cidade, foi marcado por três eventos acontecidos a partir da década de 1960: a construção de Itaipu Binacional, da Ponte Internacional da Amizade ${ }^{38}$ e da Ponte da Fraternidade ${ }^{39}$. Desse modo, a cidade não apareceu como predestinada ao turismo, destoando, portanto, da leitura das classes dominantes.

Ao contrário disso, apesar de o senhor Luis reconhecer que o turismo é a atividade mais importante de Foz do Iguaçu, ele indicou outras referências, que evidenciaram a jovialidade da cidade. Aos três eventos já selecionados, Luis acrescentou o "Parque das

${ }^{36}$ Entrevista realizada com o senhor Luis T., em 12 de janeiro de 2007, na cidade de Foz do Iguaçu.

${ }^{37}$ O Marco das Três Fronteiras é um ponto turístico localizado nas cidades de Foz do Iguaçu, Puerto Iguazú e Ciudad Del Este, referente ao local de divisa territorial, respectivamente, entre o Brasil, a Argentina e o Paraguai. O marco brasileiro, localizado no Porto Meira, foi inaugurado em 1903. O marco argentino situa-se à margem do rio Iguaçu e o marco paraguaio fica à margem direita do rio Paraná.

${ }^{38}$ A Ponte Internacional da Amizade ou, simplesmente, Ponte da Amizade, foi construída durante as décadas de 1950 e 1960. Liga a cidade de Foz do Iguaçu, no Brasil, e Ciudad Del Este, no Paraguai, passando sobre o rio Paraná. Apesar de ter sido inaugurada duas vezes (em 1961, por Juscelino Kubitschek, e, em 1965, por Castelo Branco), esta ponte começou a funcionar, efetivamente, em 1965.

${ }^{39}$ A Ponte Internacional da Fraternidade, inaugurada em 1985, é a ponte que liga Foz do Iguaçu, no Brasil, a Puerto Iguazu, na Argentina. Seu nome oficial é Ponte Tancredo Neves. As cidades de Puerto Iguazu, na Argentina, e Ciudad Del Este, no Paraguai, em conjunto com Foz do Iguaçu, formam a Tríplice Fronteira. 
Aves",40, o "Refúgio Biológico"41 e a "Iluminação Panorâmica"42 de Itaipu, todos estes criados a partir da década de 1980. Juntos, eles dividem espaço com as Cataratas e problematizam a vocação turística da cidade. De outro modo, a visão do senhor Luis inseriu a forte presença de Itaipu na constituição de atrações turísticas artificiais para Foz. Foram as obras estatais que marcaram o desenvolvimento do turismo e da cidade. Mesmo quando se trata, diretamente, de elementos articulados e destinados ao turismo, é o peso do Estado que aparece, como matriz da "vocação" turística.

Movimento de interpretação semelhante ao do senhor Luis foi apresentado na entrevista com o senhor Guilherme, 83 anos, canteiro ${ }^{43}$ e eletricista.

\begin{abstract}
"O volume de turista começou a aumentar, começou a aumentar mesmo, realmente, em [19]58 pra [19]59, porque aí, os aviões que começaram a vir pra cá eram maiores, já tinha a pista de asfalto, já era lá onde é hoje o aeroporto, já era lá. O prédio era menor; só que eles fizeram uma ampliação no prédio, mas já começou a descer, quando o Brasil começou [...] começou a operar o DART, o Agro e o Electra II, que é aqueles que, depois, fazia a linha, a ponte aérea SãoPaulo - Rio de Janeiro, era o Electra II, que fazia. Você deve se lembrar de uns aviões de 4 motor?" 44
\end{abstract}

${ }^{40}$ O Parque das Aves foi criado em 1994. Possui imensos viveiros, com, aproximadamente, 900 aves, de 150 espécies. Predominam aves brasileiras; porém, há espécies da Austrália, da África e da Ásia representadas. Possui, também, um Borboletário com, aproximadamente, 25 espécies, e o Setor de Répteis.

${ }^{41}$ O Refúgio Biológico Bela Vista foi criado pela Itaipu, em 1982, e é uma área de preservação permanente. Em 2002, foi aberto a visitação pública.

${ }^{42}$ A Iluminação Panorâmica, ou "Iluminação Monumental de Itaipu", foi criada, em 2002, pela Itaipu, e pode ser visitada à noite. Com o show de luzes, o visitante pode verificar cada detalhe da obra de concreto, principalmente, o formato de catedrais da barragem.

${ }^{43}$ Canteiro é o trabalhador que assenta pedras. Seu ofício é a cantaria, que significa talhar e assentar a pedra de forma a constituir sólidos geométricos, geralmente, paralelepípedos, para utilização na construção de edifícios ou de muros.

${ }^{44}$ Entrevista com o senhor Guilherme, em 23 de março de 2007, na cidade de Foz do Iguaçu. 
Para o senhor Guilherme, o turismo só começou a se viabilizar quando Foz pode receber vôos comerciais, a partir da reforma do aeroporto, com o asfaltamento da pista de pouso e decolagem. De fato, tal reforma aconteceu, mas foi em $1967^{45}$. De qualquer modo, o que merece ser salientado diz respeito à associação das atividades turísticas, na cidade, com a construção do aeroporto. Assim, na visão do senhor Guilherme, os turistas se tornaram significativos para Foz, apenas no final da década de 1960, após a conclusão dessas obras.

Na sua avaliação, o turismo só se tornou viável a partir da ação direta do Estado, por meio da construção de vias de acesso à cidade ${ }^{46}$. Sobre isso, recorda-se da estrada que liga Foz a Curitiba, asfaltada em 1958, embora sua memória tenha subtraído 10 anos deste fato, já que a pavimentação desse trecho aconteceu, em 1968:

\section{“[...] em 58, já ligou Foz do Iguaçu até Curitiba, já ligação de asfalto que, antes, também, era estrada de terra, até Ponta Grossa. Ponta Grossa - Curitiba tinha asfalto, mais até Ponta Grossa era terra, $700 \mathrm{~km}$ de terra... quando chovia, era 3 dias de viagem."}

De qualquer maneira, cabe ressaltar que sua leitura difere da memória oficial, à medida que ele desnaturaliza a "vocação" turística da cidade. Se houve um ponto inicial para o turismo, de acordo com o senhor Guilherme, certamente, foi o final da década de 1960, quando o Estado criou a infra-estrutura necessária para o transporte de turistas até a região de Foz do Iguaçu.

Ajuda a explicar a leitura apresentada pelo senhor Guilherme sua experiência como trabalhador no Parque Nacional do Iguaçu e seu envolvimento com o setor de hotelaria. Para

\footnotetext{
${ }^{45}$ Em 1941, foi inaugurado o Aeroporto do Parque Nacional do Iguassu, que ficou sob administração do Ministério da Agricultura, passando para a administração do Ministério da Aeronáutica, em 1949. No ano de 1967, foi inaugurada a pista do atual aeroporto, para aeronaves leves, e, em setembro do mesmo ano, aconteceu o primeiro pouso de uma aeronave comercial, um Dart Herald, da SADIA.

${ }^{46}$ Foz do Iguaçu está localizada a 637 quilômetros de Curitiba, a 1.566 quilômetros de Brasília (DF), a 1.047 quilômetros de São Paulo e a 1.472 quilômetros do Rio de Janeiro.
} 
ele, que trabalhou em hotéis, desde a década de 1940, a principal fonte de recursos para a cidade estaria ligada à vinda de turistas estrangeiros, fato que movimentava uma rede significativa de hotéis. E embora a construção da BR-277, das pontes da Amizade e da Fraternidade tenha respondido ao objetivo de aproximar o comércio do Brasil com o Paraguai e com a Argentina, o senhor Guilherme registra esses acontecimentos como fundamentais para a viabilização do turismo.

"[...] que o turista, por exemplo, vem americano, muito americano, muito japonês. A força do turismo japonês, aqui em Foz do Iguaçu, é muito grande. Grupos e mais grupos, italiano, francês, muito estrangeiro. [...] Eles trazem capital - né? -, capital de giro pro município, eles trazem o capital [...]. Olha, fica nas grandes empresas, e essas empresas, aqui, são praticamente filiais; a central deles tá em São Paulo, Rio de Janeiro, assim como o Bourbon tá aqui, mais a sede dele não é aqui: grande parte dele tá em Curitiba, São Paulo, e no norte do Paraná, o Tropical hotéis, o Cataratas - né? -, tá lá nas cataratas, mais ele tá em São Paulo, no centro de São Paulo, [...] Planalto, ele tá em Salvador, tá no Hotel da Bahia, ele tá no Hotel Internacional, em Manaus, onde é o forte dele mesmo, do Tropical, é Manaus; ele conta com um número de empregados, lá, média de 1.500 empregados."

Quando foi indagado, pela primeira vez, o senhor Guilherme respondeu que a presença estrangeira, na cidade, alimentava-a com capital, "capital de giro pro município". Contudo, sua percepção refez esta afirmação à medida que pedi a ele que explicasse o peso do setor hoteleiro, na economia da cidade. Foi então que o senhor Guilherme introduziu um elemento novo, nessa discussão, mais ou menos óbvio, mas pouco ou nada destacado pelos demais entrevistados e pelas classes dominantes. O grosso do faturamento desse setor era recolhido por suas respectivas matrizes. Se algum recurso ficava na cidade, correspondia aos impostos municipais e aos empregos gerados pelo setor. 
Esta leitura foi sublinhada, também, por um técnico do IBGE, de Foz do Iguaçu, que lá trabalhou, desde a década de 1980. De acordo com seus estudos, de todo o montante gerado pelo turismo, a maior parte era apropriada pelas empresas aéreas, de transporte terrestre e pela rede hoteleira. Pouca coisa, de fato, ficava na cidade.

Esta questão pode ser observada, também, a partir de dados estatísticos, embora eu não tenha encontrado uma série organizada de estatísticas e números sobre o a dinâmica de funcionamento do turismo. Não obstante essa dificuldade, a partir do cruzamento de alguns dados parciais sobre a atividade turística em Foz do Iguaçu, foi possível perceber, neste sentido, como a década de 1980 representou um período de grande ampliação dos equipamentos turísticos, isto é, hotéis, agências de turismo e serviços de táxi. No caso dos hotéis, a Tabela 1 permite observar tal crescimento.

Tabela 1*. Meios de Hospedagem: aberturas de alvará (1959 - 2005)

\begin{tabular}{|c|c|c|c|c|c|c|c|c|c|}
\hline Ano & № & Ano & № & Ano & № & Ano & № & Ano & № \\
\hline 1959 & 1 & 1969 & 2 & 1979 & 9 & 1989 & 25 & 1999 & 4 \\
\hline 1960 & 0 & 1970 & 1 & 1980 & 5 & 1990 & 17 & 2000 & 4 \\
\hline 1961 & 0 & 1971 & 1 & 1981 & 6 & 1991 & 24 & 2001 & 13 \\
\hline 1962 & 1 & 1972 & 1 & 1982 & 4 & 1992 & 23 & 2002 & 3 \\
\hline 1963 & 0 & 1973 & 1 & 1983 & 3 & 1993 & 21 & 2003 & 5 \\
\hline 1964 & 0 & 1974 & 0 & 1984 & 7 & 1994 & 29 & 2004 & 5 \\
\hline 1965 & 0 & 1975 & 1 & 1985 & 7 & 1995 & 28 & 2005 & 4 \\
\hline 1966 & 0 & 1976 & 1 & 1986 & 23 & 1996 & 12 & - & - \\
\hline 1967 & 1 & 1977 & 1 & 1987 & 17 & 1997 & 18 & - & - \\
\hline 1968 & 0 & 1978 & 2 & 1988 & 26 & 1998 & 11 & - & - \\
\hline \multicolumn{2}{|c|}{ 1959-1968 } & \multicolumn{2}{|c|}{ 1969-1978 } & \multicolumn{2}{|c|}{ 1979-1988 } & \multicolumn{2}{|c|}{ 1989-1998 } & \multicolumn{2}{|c|}{ 1999-2005 } \\
\hline TOTAL & 3 & TOTAL & 11 & TOTAL & 107 & TOTAL & 208 & TOTAL & 38 \\
\hline
\end{tabular}

* Tabela organizada pela autora.

F onte: Foz do I guaçu (Prefeitura Municipal de). Secretaria Municipal de Turismo. 2006, p.235. 
Segundo o levantamento feito pela Comissão de Desenvolvimento Municipal $(\mathrm{CODEM})^{47}$, em 1968, havia 18 hotéis e oito agências locais de turismo e câmbio, na cidade. Associando esse número às estatísticas feitas pela Secretaria Municipal de Turismo de Foz do Iguaçu (SMTU), sobre a quantidade de alvarás de abertura de meios de hospedagem ${ }^{48}$, liberados entre 1959 e 2005 (v. Tabela 1), e de agências de turismo existentes, entre 1967 e 2005, conforme organizado na Tabela 2, foi possível estabelecer um parâmetro para analisar a dinâmica de crescimento deste setor, em Foz do Iguaçu, entre os anos de 1960 e 1990.

Tabela 2*. Agências de turismo: abertura de alvará (1967-2005).

\begin{tabular}{|c|c|c|c|c|c|c|c|c|c|}
\hline Ano & $\mathrm{N}^{\circ}$ & Ano & № & Ano & № & Ano & № & Ano & No \\
\hline- & - & 1969 & 0 & 1979 & 2 & 1989 & 47 & 1999 & 9 \\
\hline- & - & 1970 & 0 & 1980 & 0 & 1990 & 77 & 2000 & 13 \\
\hline- & - & 1971 & 1 & 1981 & 3 & 1991 & 37 & 2001 & 15 \\
\hline- & - & 1972 & 1 & 1982 & 1 & 1992 & 23 & 2002 & 9 \\
\hline- & - & 1973 & 0 & 1983 & 0 & 1993 & 24 & 2003 & 7 \\
\hline- & - & 1974 & 0 & 1984 & 6 & 1994 & 26 & 2004 & 18 \\
\hline- & - & 1975 & 4 & 1985 & 5 & 1995 & 33 & 2005 & 11 \\
\hline- & - & 1976 & 0 & 1986 & 7 & 1996 & 25 & - & - \\
\hline 1967 & 1 & 1977 & 2 & 1987 & 25 & 1997 & 13 & - & - \\
\hline 1968 & 1 & 1978 & 0 & 1988 & 25 & 1998 & 8 & - & - \\
\hline \multicolumn{2}{|c|}{ 1967-1968 } & \multicolumn{2}{|c|}{ 1969-1978 } & \multicolumn{2}{|c|}{ 1979-1988 } & \multicolumn{2}{|c|}{ 1989-1998 } & \multicolumn{2}{|c|}{ 1999-2005 } \\
\hline TOTAL & 2 & TOTAL & 08 & TOTAL & 74 & TOTAL & 313 & TOTAL & 82 \\
\hline
\end{tabular}

* Tabela organizada pela autora.

Fonte: Foz do Iguaçu (Prefeitura Municipal de). Secretaria Municipal de Turismo. 2006, p.234.

\footnotetext{
${ }^{47}$ CODEM (Comissão de Desenvolvimento Municipal) é um órgão de apoio aos municípios, formado a partir do convênio entre a Companhia de Desenvolvimento Econômico do Paraná (Banco de Desenvolvimento do Paraná S.A) e o Departamento de Assistência Técnica aos Municípios.

${ }^{48}$ Nesse documento, divulgado pela Secretaria Municipal de Turismo, os meios de hospedagem considerados são os seguintes tipos de estabelecimentos: hotel, apart-hotel, motel, hospedaria, pousada, dormitório, albergue e camping.
} 
Partindo do intervalo 1959-2005, período que encerra os dados fornecidos pela CODEM e SMTU, foi possível perceber como a década de 1980 marcou um período de explosão, no crescimento do setor hoteleiro.

Entre 1959-1968, foram liberados três alvarás. Este número evoluiu para 11, no período de 1969-1978. Portanto, houve um crescimento de 267\%. No período seguinte, 19791989, a taxa de crescimento foi de $873 \%$, e o número de liberações de alvarás subiu de 11 para 107. Esse percentual de crescimento do setor de hotelaria, vivido na década de 1980, foi significativamente maior, não só em relação à série anterior como, também, à série posterior. Nos dez anos seguintes (1989-1998), a taxa de crescimento dos alvarás desceu para 94\%. Somando as liberações de alvarás dos períodos 1969-1978, 1979-1988, 1989-1990 aos 18 hotéis existentes, em 1968, constatou-se, mais uma vez, a importância da década de 1980 para o desenvolvimento da economia turística, no município, pois, nela, foi registrado o maior crescimento real de meios de hospedagem.

Além dos meios de hospedagem, o significativo crescimento dos alvarás de abertura de agências de turismo, em Foz do Iguaçu, pode ser considerado, também, um indicador do crescimento dos empreendimentos turísticos, na cidade, na década de 1980. Partindo dos números apresentados pela SMTU (v. Tabela 2), observou-se, entre os anos de 1979 e 1988, um aumento de $825 \%$ dos alvarás de abertura de agências de turismo, em relação ao período de 1969-1978. Em termos reais, as oito agências existentes, no ano de 1968, duplicaram, ao final de 1978, e cresceram cerca de 400\%, ao longo da década de 1980, quando já somavam 90 agências, no total.

Confrontados aos dados relacionados à População Economicamente Ativa (PEA), em Foz do Iguaçu, os postos de trabalho, no setor de serviços (onde estão incluídos os hotéis e as 
agências de turismo, por exemplo), cresceram, nítida e significativamente, na década de 1970, e não antes dela. Isto pode ser analisado a partir da Tabela 3

\begin{tabular}{|c|c|c|c|c|}
\hline \multirow[b]{2}{*}{ SETOR } & \multicolumn{2}{|c|}{1970} & \multicolumn{2}{|c|}{1980} \\
\hline & $\begin{array}{l}\text { Númer } \\
\text { os absolutos }\end{array}$ & $\%$ & $\begin{array}{l}\text { Númer } \\
\text { os absolutos }\end{array}$ & $\%$ \\
\hline Primário & 5.456 & 45,9 & 3.585 & 7,5 \\
\hline Secundário & 1.300 & 10,9 & 17.240 & 35,8 \\
\hline Terciário & 5.137 & 43,2 & 27.258 & 56,7 \\
\hline TOTAL & 11.893 & $00^{1}$ & 48.083 & $00^{1}$ \\
\hline
\end{tabular}

F onte: IPARDES. 1984, p.6.

Ao longo da década de 1970, a presença do setor primário sofreu uma drástica redução, de 45,9\% para 7,5\%. Neste mesmo período, o setor secundário elevou sua taxa de $10,9 \%$ para $35,8 \%$. Percentualmente, este crescimento correspondeu a $230 \%$, e, em grande parte, aconteceu de maneira concentrada, no setor da indústria de construção civil, impulsionado pela construção da hidrelétrica de Itaipu. O setor terciário, por sua vez, foi de 43,2\% para 56,7\%. Em grande medida, é preciso contabilizar, também, que uma parte representativa desse crescimento, verificado no setor de serviços, aconteceu "amarrada" pela construção de Itaipu, que, efetivamente, atraiu novos trabalhadores para Foz do Iguaçu, a partir de meados dos anos 70. Não expressa, portanto, um crescimento absoluto das atividades relacionadas ao turismo.

Quando esses dados são cruzados com os níveis salariais, expressos na Tabela 4, outro aspecto da realidade social e econômica de Foz chama a atenção. De acordo com a pesquisa 
feita pelo Instituto Paranaense de Desenvolvimento Econômico e Social (IPARDES), $16 \%$ da PEA, na década de 1980, recebia até um salário mínimo, $29 \%$ recebia de um a dois salários mínimos e, $18,3 \%$, de dois a três salários mínimos. Esses dados informam que $63 \%$ da mão de obra empregada, em Foz do Iguaçu, não recebiam mais que três salários mínimos.

\begin{tabular}{|c|c|c|c|c|}
\hline \multirow{2}{*}{$\begin{array}{l}\text { REND. MÉDIO MENSAL } \\
\text { (Salário Mínimo) }\end{array}$} & \multicolumn{2}{|l|}{ SEXO } & \multirow{2}{*}{ TOTAL } & \multirow{2}{*}{$\%$} \\
\hline & Homens & Mulheres & & \\
\hline Até $1 / 4$ & 191 & 396 & 587 & 1,2 \\
\hline Mais de $1 / 4$ a $1 / 2$ & 843 & 1.780 & 2.623 & 5,3 \\
\hline Mais $1 / 2$ a 1 & 2.245 & 2.717 & 4.962 & 10,1 \\
\hline ais de 1 a $1 \frac{1}{2}$ & 5.815 & 2.918 & 8.733 & 17,7 \\
\hline Mais de $1 \frac{1}{1 / 2}$ a 2 & 4.220 & 1.421 & 5.641 & 11,5 \\
\hline Mais de 2 a 3 & 7.609 & 1.386 & 8.995 & 18,3 \\
\hline Mais de 3 a 5 & 7.558 & 1.125 & 8.883 & 18,1 \\
\hline Mais de 5 a 10 & 4.931 & 574 & 5.505 & 11,2 \\
\hline Mais de 10 a 20 & 2.089 & 144 & 2.233 & 4,5 \\
\hline Mais de 20 & 998 & 38 & 1.036 & 2,1 \\
\hline SUBTOTAL & 36.699 & 12.499 & 49.198 & 100,0 \\
\hline S/RENDIMENTO & 11.055 & 34.266 & 45.321 & - \\
\hline S/DECLARAÇÃO & 133 & 137 & 270 & - \\
\hline
\end{tabular}

Fonte: IPARDES, 1982, p.8.

Essa situação parece não ter mudado, no decorrer da década de 1990. No ano de 2003, verificou-se que 59,9\% da mão de obra empregada, na cidade, estava alocada no setor de serviços (WEBBER, 2003, p.39), que 55,6\% de toda a PEA de Foz do Iguaçu tinha renda familiar até três salários mínimos. (WEBBER, 2003, p.24). Admitindo o potencial do turismo de impulsionar o crescimento e o progresso econômico de uma cidade, por meio da geração 
de empregos diretos e indiretos, não deixa de incomodar o fato de que parte significativa desses empregos gera uma renda familiar muita baixa para mais de $50 \%$ de sua população. De um modo geral, o fato de que, ao longo das décadas de 1980 e 1990, o turismo assumiu um peso fundamental, na história da cidade, não significa reconhecer que as condições de vida dos trabalhadores eram consideradas e percebidas como boas.

Acompanhando os dados organizados pelo IBGE, divulgados nos Censos de 1950, 1960 e 1970, foi possível observar que a extração vegetal e a agricultura eram, também, as principais atividades econômicas de Foz do Iguaçu.

No censo demográfico de $1950^{49}$, o IBGE apresentou os números da População Economicamente Ativa, por ramo principal de atividade. De acordo com este censo, a agricultura, seguida pela extração vegetal e mineral, era o ramo de atividade com maior participação da população economicamente ativa de Foz do Iguaçu. Entre as 11.012 pessoas com 10 anos e mais, havia na cidade 2.225 pessoas dependentes diretamente da agricultura, da pecuária e da silvicultura; 277, dependentes das atividades extrativistas; 955 pessoas dependentes do comércio de mercadorias; oito relacionadas ao comércio de imóveis, valores imobiliários e créditos, e $7.397^{50}$, ocupadas em atividades não declaradas.

O Censo Demográfico de $1960^{51}$ mostrou que os principais setores de dependência da população de Foz do Iguaçu, até o final da década de 1950, eram a agricultura e o extrativismo. Mais de $70 \%$ da população da cidade dependia dessas atividades. De acordo

\footnotetext{
${ }^{49}$ IBGE. Estado do Paraná: censos demográficos e econômicos. Rio de Janeiro, 1955. Série Regional, v.XXVI, p.82.

${ }^{50}$ No censo de 1950, o número de pessoas ocupadas em atividades não compreendidas nos instrumentos de pesquisa, mal definidas ou não declaradas foi muito maior do que a somatória de todas as pessoas dependentes dos ramos identificados nas tabelas. Isto, porém, não descaracteriza o predomínio da atividade agrícola, pois as 7.397 pessoas poderiam ocupar dezenas de outras atividades, sem constituir, propriamente, qualquer domínio sobre as outras.
} 
com a Enciclopédia dos Municípios Brasileiros, as principais atividades econômicas de Foz do Iguaçu, pelo menos até o ano de 1956, eram as atividades de extrativismo vegetal e a atividade agrícola.

\begin{abstract}
$\mathrm{Na}$ indústria extrativa vegetal está situada a atividade fundamental à economia do município. Suas imensas reservas florestais, em que predominam o cedro, o ipê, a cabriúva, o louro e o pinheiro, propiciam uma exploração industrial cada vez mais progressiva e rendosa para o município. Dos seus 50 estabelecimento industriais, 15 ocupam em sua atividade normal, 5 ou mais operários. Cerca de $70 \%$ do total situam-se na industria madeireira e os restantes na industria extrativa mineral e industria alimentar. A agricultura contribui destacadamente com parcela de suas culturas; [...]. (IBGE, 1959, p.215).
\end{abstract}

Todos esses dados, aqui apresentados, não seguem na direção de construir uma tese contra o turismo como atividade econômica relevante, em Foz do Iguaçu. Ao contrário, o que se pretende é chamar a atenção para o fato de que, a despeito dos objetivos implícitos das classes dominantes, de valorizar o turismo como atividade econômica indispensável à cidade (objetivos esses discutidos, no segundo capítulo), resta claro que o crescimento do turismo teve seu tempo, a partir da década de 1970, e não antes dela.

Os trabalhadores entrevistados reforçam tal visão sobre o turismo, mas fazem-no desmontando a idéia de que a cidade não nasceu vocacionada para ele, já que todas as referências decalcadas no turismo são recordadas e fixadas, dos anos finais da década de 1960 em diante. Em resumo, os trabalhadores indicam como o turismo, na cidade, foi e continua sendo uma construção artificial, particularmente escorada pelo Estado.

Retomo essa discussão a partir da entrevista com a senhora Guilhermina. Sua narrativa indica três pontos importantes para o surgimento e o desenvolvimento do turismo: a

\footnotetext{
${ }^{51} \mathrm{O}$ censo usou o indicador Ramo de atividade de dependência para classificar a população da cidade, de acordo com o ramo de atividade econômica dos quais dependem. (Cf. IBGE. Censo Demográfico de 1960. Curitiba (PR), 1960. Série Regional : vol.1, tomo XIV).
} 
divulgação das Cataratas como destino turístico, a construção da Ponte da Amizade e a construção de Itaipu. Este último elemento foi responsável, na sua visão, por atrair milhares de novos trabalhadores que se fixaram, na cidade, por muitos anos. A Ponte da Amizade foi responsável por estabelecer um fluxo comercial (mesmo que ilegal, em parte) com Ciudad Del Este, no Paraguai. Estes são eventos do final de meados da década de 1970 e final da década de 1960, respectivamente. Contudo, é falando sobre as Cataratas que dona Guilhermina reafirma como a "vocação" turística é artificial.

"E... mas tem famílias que moram aqui, em Foz do Iguaçu, anos, e que nunca foram conhecer [as cataratas], sabe? Então, muita gente não dava... gente da época não dava muito valor a isso, achava que isso era um... 'Ah, água caindo, o que tem a vê?' Mas nunca foram ver a maravilha que é. Então, depois que... é, mais pessoas começaram a conhecer, viram o espetáculo que é aquilo ali, aí começou. [...]. Eu sempre digo... muita gente já vinha, porque via pessoas que vinham morar pra cá, se comunicavam, através de cartas, com as famílias e diziam; porque, antigamente, era só carta, não tinha outro jeito de se comunicar, né? E depois, quando começou os rádios amador, pelo batalhão, o exército né? -; vinham, às vezes, militares de fora. Então, aí que começou, assim, a divulgar."

Mais uma vez, a presença do Estado é destacada como protagonista, na estruturação do turismo. A divulgação das Cataratas começou, de acordo com dona Guilhermina, por meio do Exército. Para ela, as cataratas não eram algo significativo para os moradores de Foz, antes da visita sistemática de turistas.

Portanto, a beleza "natural” das cataratas não era um fato. "Água caindo, o que tem a vê?"'. Talvez, esta percepção esteja mais próxima da realidade, embora as quedas d'água, do 
lado argentino, tenham sido "vistas" como beleza, desde o final do século XIX. Sobre isso, vale a reflexão de Raymond Williams (1990) acerca do surgimento das "paisagens", ou seja, algo que foi realçado, a que se deu destaque, com o objetivo de ser observado e contemplado. Falando sobre o contexto dos cercamentos ingleses dos séculos XVII e XVIII, para ele, tornar a natureza observável representaria recolocá-la dentro de um ponto de vista específico cujo objetivo seria adaptá-la ao interesse do capital:

\begin{abstract}
O traçado geométrico dos cercamentos, com suas sebes e estradas retilíneas, é contemporâneo das curvas e irregularidades das paisagens dos parques. E, no entanto, são partes inter-relacionadas de um mesmo processo que se opõem superficialmente em termos de gosto, mas apenas porque, num dos casos, a terra está sendo organizada para a produção, para ser trabalhada por arrendatários e trabalhadores; enquanto no outro está sendo organizada para o consumo: a vista, o descanso organizado do proletário, a paisagem. (WILLIAMS, 1990, p.167).
\end{abstract}

O turismo relacionado à Foz do Iguaçu tem essas características. Quem visita esta cidade pretende se encontrar com as Cataratas. Tais pessoas formam um tipo, cuja principal característica é a de "consumir" a Natureza, de "devorar" a paisagem. (BOYER, 2003, p.55). São "turistas de massa", que só se constituíram, recentemente, nos anos finais da década de 1960, quando a ecologia começou a se tornar uma questão importante na vida das pessoas.

No conjunto das entrevistas analisadas, foi possível observar o quão contraditório é o processo de reprodução da memória oficial. A incorporação desta memória pelos trabalhadores não responde diretamente às idéias e percepções elaboradas pelas classes dominantes. Até mesmo porque tais classes não têm o controle sobre o modo como os eles manejam os elementos da memória oficial, articulando-a à sua própria. Nesse sentido, coube observar como as trajetórias de vida dos trabalhadores entrevistados foram determinantes para reformular as idéias das classes dominantes, moldando-as segundo suas próprias experiências na cidade. 
Assim, as narrativas dos trabalhadores podem ter reforçado e confirmado elementos da memória oficial sem, contudo, legitimá-la por inteiro. $\mathrm{Na}$ realidade, avalio que esses trabalhadores foram além desta memória oficial. Eles recordaram uma cidade que traz suas próprias marcas. Sem apresentar uma discordância extremada sobre a memória oficial, narraram a cidade a partir de suas próprias experiências ou, melhor dizendo, a partir do que interpretaram ser suas experiências ${ }^{52}$. Não negaram determinadas imagens, consolidadas pelas classes dominantes, mas refizeram-nas, segundo seus propósitos e percepções, especialmente a partir do lugar social que ocuparam e ocupam. Este é o tema do quarto e próximo capítulo.

\footnotetext{
52 Nesse sentido, tem razão Alistair Thomson (1997, p.57), quando sugere que o "processo de recordar" apresenta-se como "uma das principais formas de nos identificarmos quando narramos uma história. Ao narrar uma história, identificamos o que pensamos que éramos no passado, quem pensamos que somos no presente e o que gostaríamos de ser.”.
} 


\title{
CAPÍTULO 4.
}

\section{Memórias confrontadas: as cidades dos trabalhadores.}

\author{
“[...] porque nossa cidade mudou, mas mudou pra quem tá lá; \\ pra mim, eu nem me comparo que mudo; que o meu salário \\ não mudou, minha vida é pobre igual [...], mudou o que? Pra \\ mim, nada. [...]. Tô na mesma de trinta e poucos anos atrás, \\ né? Salário mixado, vida pobre; não tem nada, né? Pronto, é \\ isso mesmo." (Dona Margarida, 63 anos).
}

O objetivo deste capítulo é discutir a cidade de Foz do Iguaçu, referenciando-me em experiências de trabalho relatadas por entrevistados que lá residem, desde, pelo menos, a década de 1970. O que se pretende é analisar como os trabalhadores narram, a partir de seus modos de viver, morar e trabalhar, o processo histórico que marcou o crescimento urbano e a ampliação do turismo, na cidade de Foz do Iguaçu.

Esses trabalhadores, quando foram indagados sobre as visões da cidade elaboradas pela memória dominante, reproduziram, ainda que de maneira contraditória, o estereótipo do local como pólo turístico. Entretanto, quando falaram sobre suas trajetórias de vida e de trabalho, na cidade, revelaram outras dimensões de Foz do Iguaçu. Essas narrativas conferiram outros sentidos à prática do contrabando, problematizaram a construção da Usina de Itaipu como fator de desenvolvimento urbano e, por fim, expuseram o efeito segregador e explorador do turismo em relação aos trabalhadores na cidade. 
Desse modo, tornou-se importante tratar as questões relacionadas à história de Foz do Iguaçu a partir de suas experiências com o trabalho ali vividas. Embora seus relatos tenham sido biográficos, informando percepções individuais sobre diversos significados de morar e trabalhar nessa cidade, foram, também, em grande medida, a expressão de vivências de situações comuns, como o trabalho na fronteira, em Itaipu e no turismo de Foz. Nesse sentido, representam uma vivência coletiva de experiências sociais muitas vezes compartilhadas.

O principal ponto a ser destacado, na análise dessas entrevistas, refere-se à fusão da própria vida com a historia da cidade. Os eventos são citados e explicados sempre de um ponto de vista particular, mas ainda é sobre a cidade que se fala. E uma vez que esses trabalhadores articulam a cidade às suas memórias, fazem-no, principalmente, em relação ao trabalho, às ocupações exercidas e ao patrimônio herdado, como foi possível perceber no terceiro capítulo.

Contudo, se essa fusão torna a narrativa mais interessante de ser estudada, não retira dela o tom recorrentemente fragmentário da recordação. Portanto, ao lidar com as narrativas dos entrevistados, não se trata de extrair informações ou contestar fatos, mas de apresentar outras memórias acerca da história vivida na cidade. Assim, tem razão Alistair Thomson (1997, p.57) quando sugere que o "processo de recordar" apresenta-se como "uma das principais formas de nos identificarmos quando narramos uma história. Ao narrar uma história, identificamos o que pensamos que éramos no passado, quem pensamos que somos no presente e o que gostaríamos de ser.”. Foi escorada nessa percepção acerca da História que interpretei as narrativas dos trabalhadores entrevistados sobre Foz do Iguaçu.

Os trabalhadores que entrevistei não apresentaram uma discordância extremada, em relação à memória oficial, mas narraram a cidade a partir de suas próprias experiências ou, melhor dizendo, a partir do que interpretaram ser suas experiências. Não negaram determinadas imagens consolidadas pelas classes dominantes, mas refizeram-nas, segundo seus propósitos e percepções. 


\subsection{Cidade, trabalho e fronteira.}

Como pode ser observado no terceiro capítulo, o turismo, enquanto atividade econômica relevante, foi, para os trabalhadores, um evento recente, na história da cidade. Deste modo, suas narrativas de vida revelaram uma trajetória ocupacional diversificada, que correspondia aos seus esforços para sobreviver, na cidade, nos mais diferentes contextos. Neste sentido, chamou minha atenção como foram recorrentes, nas narrativas dos trabalhadores, relatos sobre o trabalho relacionado ao comércio de mercadorias com as cidades fronteiriças, Puerto Iguazu (Argentina) e Ciudad del Este (Paraguai).

Essas narrativas de vida indicaram que o envolvimento dos trabalhadores no comércio de mercadorias, na fronteira, não era um fenômeno recente, na história da cidade. Ao contrário, os relatos apresentados sugeriram que este comércio constituiu uma forma bastante comum e cotidiana de estratégia de sobrevivência de muitos trabalhadores, desde a década de 1940.

Segundo a senhora Francisca ${ }^{53}$, de 81 anos, era comum, para as famílias que viviam em Foz do Iguaçu, ir até a cidade de Puerto Iguazu comprar produtos alimentícios manufaturados. Isto ocorria num contexto em que o comércio local de Foz do Iguaçu era pouco desenvolvido, combinado ao fato de que os produtos argentinos eram mais baratos e de melhor qualidade.

“Nóis mesmo comprava só de lá, farinha de trigo, óleo... Afinal, tudo, tudo, muito barato; e tinha o que percurasse ali; tinha e comprava, e não tinha esse incômodo que tem hoje. Tá certo, os documento a gente dexava na gendarmeria [posto de guarda do exército] - que diziam, né? Mas era uma coisa certa: a gente entregava os documento ali e ia fazê compra; podia trazê o que quizesse. E na vorta, chegava ali, eles entregava os

\footnotetext{
${ }^{53}$ Dona Francisca nasceu em Foz do Iguaçu, em 1927. Atualmente, mora no bairro Vila Yolanda.
} 
documento, e [a gente] ia embora. E agora, eles que é muito exigente e tudo; antes, não era, e compravam o que tivesse lá; podia comprá e trazê.,, 54

O senhor Carlos, 61 anos, dizia que este comércio era frequente e livre. Como ele mesmo frisou, era um comércio para abastecimento, como se fosse um supermercado: acontecia como "aqui a gente vai ao mercado todo mês". Sua mãe caminhava um trajeto de, aproximadamente, seis quilômetros, "com carga nas costas, pra trazer as compras", que davam para a família consumir, durante quinze dias.

"Sim... e era livre; só que o pessoal ia lá pra abastecer, como, aqui, a gente vai ao mercado, todo mês, o pessoal daqui ia lá - né? - ; ia, e, muitas vezes, aquele que tinha menos recursos ia de a pé; minha mãe cansou de ir de a pé. Seis quilometros, fazer de a pé, com carga nas costas, pra trazer - né? - as compras pra nós passar, as vezes, quinze dias, um mês."

A população local buscava, na Argentina, produtos industrializados, que não conseguia produzir na cidade nem trazer de Curitiba. A necessidade de abastecimento mobilizava parte considerável da população local, ao ponto de despertar a oferta de serviços de transportes para aqueles que iam para a Argentina.

"[...] um senhor... que ele começou de fazer transporte pro Porto Meira, que o pessoal fazia muita compra na Argentina, ali pelo Porto Meira... E que a cidade era mais abastecida pela Argentina, né? E o que tinha que vim vinha, aqui, pela estrada velha de Guarapuava, de carroça; então, daí, ele tinha um caminhãozinho $e$ começou de fazer transporte, levar o pessoal que queria fazer compra, né? Era muito bom, como até hoje, o produto comestivel da Argentina, não desmerecendo o nosso produto brasileiro; mas, olha, é muito bom o produto comestivel da Argentina. É coisas feito da farinha de trigo, macarrão, queijo, doces enlatados, conservas, bebidas, licor, vinho... É... como eu disse, não desmerecendo o nosso produto brasileiro, mas o argentino é de muito boa qualidade, até o dia de hoje, e o pessoal ia lá abastecer [...]."

${ }^{54}$ Essa entrevista, como as que serão proximamente apresentadas, foi realizada pela autora desta tese com Francisca, no bairro Vila Yolanda, em 31 de janeiro de 2008. Nos casos de citação de entrevistas realizadas por outros autores, estes serão especificamente identificados. 
O senhor Carlos avaliou que a dificuldade e a morosidade do transporte de mercadorias vindas de Guarapuava (PR) contribuíam para a busca de produtos na Argentina. Separada por uma distância de mais de 700 quilômetros de Curitiba, a cidade de Foz do Iguaçu sofreu com a falta de abastecimento de produto nacionais, pois a pavimentação da única estrada que a ligava ao restante do estado só foi realizada em 1969.

Os trabalhadores, que viviam, em sua grande maioria, em chácaras, roçados ou casas distantes do perímetro urbano, não iam até a cidade de Puerto Iguazu apenas para comprar o que lhes faltava, mas acorriam para lá também com o objetivo de comercializar parte de sua produção agrícola e pecuária. A esse respeito, o senhor Carlos se lembra de ter visto sua mãe indo até o Porto Meira para vender laranjas e comprar maçãs dos comerciantes argentinos.

“[...] minha mãe pegava e levava laranja, daqui pra lá, e trocava por maçã. Lá não tinha laranja, naquela época. Não sei que troca que fazia - né? -, qual era o valor na troca, mas ela levava sacolada de laranja e trazia maçã, em troca."

Essa aparente insuficiência econômica de Foz do Iguaçu parece ter motivado uma economia de trocas fronteiriça, alimentada pela oferta de produtos que eram complementares para os moradores de Brasil e Argentina.

Tal divisão do trabalho parece ter existido, desde o final do século $\mathrm{XIX}^{55}$, e a falta de regulamentação desse comércio, na fronteira, foi bastante criticada, nos Relatórios do Exército, já durante sua instalação, quando criou a Colônia Militar de Foz do Iguaçu, em 1889. Aliás, quando se criou legislação específica sobre importação e exportação de produtos, o exército passou a enfrentar conflitos com os moradores locais. Neste novo quadro econômico, a imposição de taxas de importação e exportação provocou o aumento do custo de

\footnotetext{
${ }^{55}$ Os relatos indicam que "Por ocasião da descoberta da Foz do Iguassú o território brasileiro já era habitado. Existiam no mesmo 324 almas, assim descriptas: brasileiros, 9; francezes, 5; hespanhoes,2; argentinos, 95; paraguayos, 212; inglez, 1.” (BRITO, [1938] 1977, p.60).
} 
vida da população local, que dependia da importação de produtos de primeira necessidade, vindos da Argentina. A direção da colônia tentou solucionar esta situação, pedindo isenção fiscal ao governo federal: "Diz o diretor que torna-se necessário habilitar o porto da colonia, isentado-a de direitos por espaço de 10 annos, porque só assim poderão os gêneros de primeira necessidade ser directamente recebidos de Montividéo e por um preço muito baixo." (BRASIL, 1895, p.51).

A julgar pela observação feita por Arthur Franco, em sua visita a Foz do Iguaçu, esta situação de carestia não havia mudado muito, em 1913. Ele considerava que os impostos de importação tornavam a vida da população local "caríssima”, obrigando-a a apelar para o contrabando, para garantir sua sobrevivência:

A nossa palestra com o sr. Bonjean versou também sobre os impostos de importação cobrados pelo fisco federal naquela zona fronteiriça, então sem comunicação com o interior, de modo a ser obrigada a receber tudo do estrangeiro, mesmo os gêneros alimentícios de primeira necessidade, como carne verde, roupas, e toda a sorte de gêneros alimentícios, o que tornava a vida ali caríssima e 'quase obrigatório' o contrabando para a população daquela zona poder sobreviver. (FRANCO, 1973, p.74).

Quando a fundação da colônia instituiu o controle do comércio, na fronteira, tornou ilegal a forma de reprodução da economia local. Além de inviabilizar o intercâmbio de gêneros alimentícios e bens manufaturados, tal controle dificultou, também, a venda de madeira e de erva mate, que garantiam o fluxo monetário e a compra de mercadorias trazidas da Argentina. As taxas de importação tornaram parte do processo de reprodução econômica local inviável, porque o encarecia muito. Somente por meio do contrabando, ou seja, da compra de produtos estrangeiros sem pagamento de taxa de importação, era possível abastecer a população que vivia nos limites da colônia. Vista deste ângulo, a compra de produtos que 
vinham da Argentina e do Paraguai, tal como era realizada pelos moradores locais, antes da fundação da colônia, passara a ser caracterizada como contrabando.

Esta contradição entre a realidade concreta da dinâmica econômica local e as determinações legais do Estado atravessou os anos e engendrou a própria história da cidade de Foz do Iguaçu. Mesmo depois da extinção da colônia militar e da elevação de Foz do Iguaçu ${ }^{56}$ à categoria de vila (1914) e, posteriormente, à de cidade (1917), tal contradição permaneceu, como traço característico de sua vida econômica e social. Nos relatos de viajantes que conheceram Foz do Iguaçu, como Arthur Franco, em 1913, Jaime Ballão, em 1920, e Lima Figueiredo, em 1937, persistiram as observações sobre o predomínio da exploração extrativista em detrimento da agricultura, a dependência local dos produtos importados da Argentina e a prática recorrente do contrabando pela população local.

Assim, o abastecimento de produtos de primeira necessidade continuou a depender do comércio com os argentinos. A forma mais eficaz de promover o fluxo monetário para comprar esses produtos se dava por meio da exploração extrativista e pela agricultura e pecuária, praticadas em todas as propriedades. Estas eram atividades que incentivavam as trocas locais ${ }^{57}$. Este "contrabando" foi comum, ainda durante as décadas de 1930 a 1970. Por fim, pode-se afirmar que Foz tinha maior ligação econômica com a Argentina do que com Curitiba e o restante do Paraná.

\footnotetext{
${ }^{56}$ Formação administrativa da cidade de Foz do Iguaçu: "Distrito criado com a denominação de Iguassu, pela lei estadual nº 971, de 09-04-1910, subordinado ao município de Guarapuava. Em divisão administrativa referente ao ano de 1911, o distrito de Iguassu figura no município de Guarapuava. Elevado à categoria de vila com a denominação de Iguassu, pela lei estadual no 1383, de 14-03-1914, desmembrado de Guarapuava. Sede da antiga colônia de Foz de Iguassu. Constituído do distrito sede. Instalado em 10-06-1914. Elevado à condição de cidade, com a denominação de Foz do Iguaçu, pela lei estadual no 1658, de 03-03-1917." Disponível em: http://www.ibge.gov.br/cidadesat/default.php. Acesso em 12 de março de 2007.

57 As empresas estrangeiras exerceram o domínio econômico de Foz do Iguaçu e toda a região do Oeste paranaense, até a década de 1940, com a exportação legal ou ilegal de erva mate e madeira para o mercado argentino. Este predomínio formava um ciclo vicioso de dependência, em relação ao mercado argentino.
} 
Um exemplo das práticas comerciais existentes, na fronteira, foi relatado pelo senhor Adolfo, 67 anos. Ele levava o leite, que produzia em sua chácara, para vender, no outro lado da fronteira. Perguntado sobre a existência desse comércio, ele respondeu que

\begin{abstract}
"Antigamente, sim, existia. Hoje, daí, já mudou. Antigamente, tudo o que nós plantava nós vendia pra Argentina. Tinha freguês na Argentina. Recebia em peso [moeda argentina] e trocava. [...] Trabalhei de 1935 a 1955, mais ou menos. [...] vendia cento e poucos litro [de leite] cada dia. Atravessava o rio de canoa. $O$ meu cunhado também ia pra lá. O meu irmão também... levava leite pra lá, ajudava levar. A mãe tirava o leite, $e$ nós levava lá. [...] comprava coisa lá. Coisa de comer, comprava tudo lá: azeite, tudo essas coisa... comprava lá."
\end{abstract}

Pelo relato do senhor Adolfo, o comércio era bastante intenso, envolvendo grande parte da família. No seu caso, que produzia leite, as idas até o lado argentino eram diárias. Para outros entrevistados, esse comércio era sistematicamente praticado por aqueles que moravam próximos às margens do rio Iguaçu, pois era mais viável atravessar o rio e vender leite para os argentinos, devido à distância que os separava da área urbana de Foz do Iguaçu.

É o que narrou o senhor Luís T., 62 anos, irmão do senhor Adolfo. Para ele, esse comércio era mais comum para as famílias que moravam às margens do rio Iguaçu. Perguntado se, de fato, os produtos argentinos tinham importância econômica para as pessoas que residiam na cidade de Foz, ele respondeu o seguinte:

"Não vou dizer os de lá de dentro da cidade; mas pros que moravam mais pro interior, tinha, porque, por exemplo, o Jorge Lack, o... o... José Schilegel, eles forneciam o leite pra Argentina, porque se eles fossem fornecer, aqui, da barranca do rio Iguaçu, o leite pra cidade... e aqui, como era o comércio pequenininho, não tinha como eles entregar tanto leite, que já tinha o Gregório Dotto, lá em cima, que fornecia o leite pra cidade, ele já quase abastecia a cidade toda com leite. Então, Jorge Lack, José Schilegel, ooo Henrique Perkoski, eles levavam o leite pra Argentina $e$ 
compravam os produtos de lá. Então, pra eles era vantagem, aqui, o comércio da Argentina."

Seu raciocínio reforça a idéia de que o trânsito comercial, na fronteira, não era praticado por todos, mas acontecia dentro de determinada divisão do trabalho. Os brasileiros, que vendiam produtos in natura para o lado argentino, principalmente leite, residiam fora do centro urbano, porque retiravam seus produtos do campo. Mas eram eles que abasteciam a cidade de Foz com mercadorias argentinas.

O senhor Luís T. observou, também, que este trânsito comercial com a Argentina promoveu o desenvolvimento de outra atividade econômica: o transporte de pessoas e de mercadorias, entre Puerto Iguazu e Foz do Iguaçu.

\begin{abstract}
"É...cada qual praticamente tinha sua canoa, e aquele que não tinha canoa cruzava, lá no Porto Meira: lá tinha os passe que levavam e traziam, né? [...] No começo, era remo; depois, já veio... apareceu o motor; então, cada um tinha o seu motorzinho e levava e trazia o pessoal, cobrava o passe e levava. Era o Lourenço Siqueira, daqui, com o Guilhermo Osci, da Argentina, o Natálio Padilha, daqui, com o Lucas, da Argentina, e o Lourenço Siqueira, daqui do Brasil, com os Troski, da Argentina, Francisco Lustroski. Então, eram esses três... que faziam três duplas: três, da Argentina, e três, do Brasil. Aí, ganhavam muito dinheiro, né? Porque, lá, sempre ia muita gente pra Argentina e vinha da Argentina, até que saiu essa ponte... aí, acabou... as balsas, né? [risos]. Acabou... acabou... não tem mais."
\end{abstract}

Sem nenhuma infraestrutura de navegação que facilitasse a transposição da fronteira molhada, aqueles que transitavam para a Argentina organizavam, também, o tráfego em geral, tanto de coisas quanto de pessoas. A canoa, tomada como transporte popular, cumpria, certamente, um papel fundamental, na ligação das pessoas e das economias dessas duas cidades, Foz e Puerto Iguazu, partindo do Porto Meira ${ }^{58}$. Tornou-se, também, um negócio, principalmente, depois que recebeu motor de popa, o que deve ter facilitado, ainda mais, o 
trânsito de pessoas e coisas. Para o senhor Luís, "três duplas" organizavam a travessia, prestando um serviço cuja existência fixou-se em sua memória. Este "serviço" existiu, até ser substituído por uma balsa e, depois, pela Ponte da Fraternidade.

Neste universo de trocas, desenvolveu-se, também, entre os moradores da cidade, práticas de compra de produtos, em Puerto Iguazu, para revenda, em Foz. A senhora Crispina, 68 anos, conta que enquanto seu pai vendia laranjas para comerciantes argentinos, no Porto Meira, ela e sua irmã iam para Puerto Iguazu, para vender laranjas e comprar produtos para revender em Foz do Iguaçu.

"E depois, depois de estudá ${ }^{59}$, é que nóis comecemo a trabaiá na Argentina, vendendo laranja lá. O pai entregava o barco, e nóis, também, levava e vendia tudo bem. A gente entrava lá e vendia tudo, tudo. E comprava trigo, óleo, sabão, essas coisa, que vendia aqui. Trazia e vendia; no outro dia, ia de novo [risos] ${ }^{60,}$

Para dona Crispina, esta atividade constituía-se numa forma de trabalho para garantir a sobrevivência da família. Desde criança, ela aprendeu com seu pai a se desdobrar em mais de uma atividade para sobreviver.

"Ele é... aquele tempo, trabalhava na roça só. Ele, assim, fazia chão pros outro. Quando nóis tinha assim oito, deiz ano, nóis trabaiava junto com ele, também, assim, cortando cana: fazia feixe de cada cana, fazia feixe... era um canavial grande. E assim, nóis ia ajudando ele. Depois, ele foi fabricante de melado, rapadura, de bala, tudo criança, né? A gente puxava o cavalo; tinha um cavalo que era manso, a gente ia em cima, puxava, ajudava ele. Era o serviço de levá lá... levá lá, pro centro, porque lá era... agora é cidade. Mas antes, era uma ruinha de chão, só pra cavalo e pra carrocinha pequena e a pé; não existia carro, naquele tempo. Assim, nóis se virava, ajudava o pai e... ajudava, na roça, e

\footnotetext{
${ }^{58}$ Porto Meira localiza-se na margem do rio Iguaçu, no local onde era feita a travessia de barco para a Argentina, antes da conclusão da Ponte da Fraternidade. A localização da área deste porto pode ser conferida no Mapa 1.

${ }^{59}$ Dona Crispina e sua irmã estudaram até a $4^{\text {a }}$ série. Ela ingressou na escola com 8 anos e saiu, aos 12 anos de idade.

${ }^{60}$ Entrevista com a senhora Crispina, em 26 de março de 2007.
} 
trabaiava, na roça, ajudava e... era pequeno, mas ajudava. [...] Não, no que ele trabaiava; ele prantava, na terra dele, o que precisava pro gasto, assim, né? Pra fazê pra vendê um poco, né? Mais nóis ajudava, em canavial, e os vizinho... Assim, nóis ganhava, ele ganhava também; nóis ajudava ele. [...] É... ele trabaiava pros outro, assim, né? Carpindo... quando tinha carpida, ele ia, né? De veiz em quando, nóis ia longe, ajudá ele carpi arroizal. A mãe, aí, levava armoço pra longe. E assim, nóis vivia. Além da nossa roça, ele fazia pros outro, trabaiava num monte de coisa."

Se, por um lado, a venda de produtos in natura, no lado argentino, constituía-se numa estratégia para sobreviver, por outro lado, não era a única atividade a que recorriam os trabalhadores do lado brasileiro. A senhora Crispina lembra que seu pai se ocupava de muitas atividades, para garantir o sustento da família. Trabalhava em culturas sazonais, como a do arroz, além de plantar roçados que lhe permitiam negociar com argentinos e, certamente, alimentar a própria família. Também, fica claro que ,sem o amparo do trabalho doméstico, seu pai não conseguiria trabalhar. Desse modo, a sobrevivência não era algo fácil.

O senhor Carlos, apesar de ser pedreiro, também fez do comércio de mercadorias, na Argentina, uma forma de resolver os momentos de crise e de falta de emprego. Ele comprava produtos, na Argentina, sob encomenda.

"E sempre gostei de negociar. E tempos atrás, também, eu desempregado... aí, eu trazia também coisa da Argentina, comestivel e tudo, pra vender aqui. Praticamente, como se diz hoje, não era registrado, né? Era um mercado negro, né? E vendia de tudo; o que me pedia eu trazia... trazia, olha, bebida, comestivel, perfume, o que pedisse eu trazia. E a gente ia pra Argentina, em Porto Iguaçu, de canoa a remo, passava o rio e trazia; trazia à vontade, não tinha controle nenhum, não tinha fiscalização que barrasse, nem lá nem aqui. Então, a gente viveu um tempo disso aí, também, né?"

Este tipo de atividade parecia encontrar uma demanda significativa, na cidade, não apenas por parte de pequenos comerciantes, mas, também, de outras empresas, como os hotéis. O senhor Carlos recorreu a esse comércio, até meados dos anos 1970. Grande parte das 
encomendas recebidas era vendida para hotéis. De licores a azeitona e picles, ele abastecia até grandes hotéis, como o Carimã, construído em 1967.

Mas esta atividade foi se tornando perigosa, devido à fiscalização, fato que levou o senhor Carlos a abandoná-la. Ele informou que a decisão de fiscalizar foi dos dois países. Ele não se lembra, exatamente, quando isso começou, mas disse que "foi por volta da década de 1970".

"De lá, também, começaram a perseguir, e do lado de cá, também; então, foi ficando difícil e... - né? - ...que... veja como é que são as coisa, né? É... do lado de cá, sempre tem o jeitinho brasileiro, né? Uma vez - né? -já tava sendo perseguido, e devia de ter largado com tempo; mais eu tava insistindo. Aí, eu tava junto com outras pessoa - né? -, e ia insistir - né? -, mesmo sendo proibido. Estavam perseguindo - né? -, eu tava indo pro lado de lá... canoa de remo - né? -, umas cinco, seis pessoas dentro, e coisa... e vem a Marinha brasileira e prende nóis, não... lado brasileiro - né? -, nós estamos no Brasil. Aí, leva até no porto, tudo mundo preso - tá preso, tá preso! Vamos ver o que que vai dar, né?"

De fato, a fiscalização argentina se tornou rigorosa, na década de 1970, o mesmo ocorrendo com a fiscalização brasileira. Havia um motivo visível, e deveu-se ao contrato realizado entre Brasil e Paraguai para a construção de Itaipu, fato que inviabilizou os planos argentinos de edificar duas usinas hidrelétricas com o Paraguai, acirrando, ainda mais, a postura defensiva que a Argentina assumira em relação ao Brasil, desde a década de 1950 (MONIZ BANDEIRA, 1995, p.241-242). A contrariedade argentina foi manifestada, no endurecimento das fronteiras, o que aconteceu, também, por parte do Brasil. Isto tornou difícil para os citados trabalhadores a continuidade dessas atividades. Aquela que era uma forma livre de sobreviver foi sendo criminalizada. 
A maioria dos trabalhadores, por medo de serem presos, deixou de fazer o comércio de produtos vindos da Argentina. O senhor Carlos, também. É certo, porém, que sua iniciativa de buscar outra forma de trabalho se relacionou com seu medo de ser preso pelos argentinos:

“[...] do lado de lá, não tem jeitinho brasileiro; lá, eles maltratam. Já leva pra Possadas - né? -, pra capital da província, né? [...] Lá, o bicho pega. Aí, eu parei e pensei... digo assim... Mas tem outro jeito de ganhar a vida; vou largar disso hoje; não vou mais... Meu cunhado, esse que tu foi entrevistar ele, lá, uma semana depois, ele mais os companheiro deles caíram, foram preso na Argentina, ficaram 24 horas sem comer, né? Ficaram preso, lá; tomaram tudo as coisa, tomaram a canoa deles, né?..."

É interessante confrontar os relatos desses entrevistados que falam de como era tranqüilo o comércio de mercadorias, na fronteira, entre as décadas de 1940 e 1960, com esta descrição feita pelo senhor Carlos. Ele disse que a fiscalização mais agressiva começou a ocorrer, por volta dos anos de 1970. Quando deixou de realizar essa atividade, tinha, aproximadamente, 28 anos. Isto aconteceu por volta de 1974. Na memória dele, a década de 1974 deixou registros de um processo de criminalização de práticas costumeiras de comércio e de trabalho, que ele aprendeu a realizar na infância.

A senhora Militona ${ }^{61}, 71$ anos, depois de trabalhar 16 anos ao lado do marido, em uma olaria localizada no bairro Carimã, com o fechamento desta, em 1970, passou a trazer encomendas de produtos da Argentina:

"Depoi nóis se mudemo pra cá e começô a trabalhar em compra e venda da Argentina. [...] Trazia de lá sabão, farinha de trigo, arroz, graxa - gordura, né? Banha de porco, assim, em lata, e trazia azeitona, óleo, essas coisa [...] macarrão, nóis chamava Lageta... Tinha, assim, uma massa, chama lagueta; tinha uma massa, parecia um pãozinho, assim, ela vendia bastante, né? Cebola, batatinha... trazia isso, de lá pra cá, e já vendia pra cá, pra cidade... levava. Então, eu fazia tudo anotadinho:

\footnotetext{
${ }^{61}$ Entrevista com a senhora Militona, em 27 de março de 2007, na cidade de Foz do Iguaçu
} 
quê queria fulano, fulano quer tal coisa, tal coisa, tal coisa.

No entanto, os relatos da senhora Militona, a exemplo de outros, sugeriram que houve, por parte da aduana, um rigor maior, em meados da década de 1970, e isto dificultou o comércio.

"[...] num deixava mais passar nada, como agora, no Paraguai, né? Num deixava passar mais nada, só pouquinho, pouquinho, e só para compra de casa, né? E nóis fazia assim: compra e venda - comprava as coisas lá e trazia a vendê, aqui ;e fazia tudo a nota, assim; cada um pedido, assim, e depoi, eu ia pegá todo mundo, a vizinhança, né? Ia comprá, lá, e trazia vendê, pra cá. E daqui, eu levava pra lá; coisa que num tem lá nóis levava lá. E assim, era nossa vivência, antes."

Seguindo o mesmo caminho, o senhor João $S^{62}$, 66 anos, descreveu o comércio de produtos da Argentina, criando uma explicação para a definição de contrabando. Para ele, durante algum tempo, os limites de compra eram altos, e era muito comum ver os moradores de Foz ir até Puerto Iguazu para comprar trigo, macarrão, azeite etc. Até aquele momento, o comércio era considerado legal. Mas, quando a compra de mercadorias, na Argentina, passou a ser feita em grande escala, com a única finalidade de revenda, foi caracterizada como contrabando. De fato, as falas dos trabalhadores anteriormente entrevistados indicaram que grande parte do comércio realizado com argentinos visava o consumo familiar ou de pequena escala. Para o senhor João, a repressão ao comércio buscava coibir essa nova fase, marcada pelo transporte em escala dos produtos argentinos.

"Não, de começo era só pra consumo. Aí, despois que agradô a cidade, aí já começô a vendê. Aí, quando começô vendê, aí, já começô o tal de contrabando, né? Aí, a turma já queria trazê em grande escala. Aí, já começaram a proibi, mais apertá... é... até nóis, depois, tinha que trazê mais poco, né? I... Eles começaram apertá, né? Que nem aqui, né? Na ponte com o Paraguai. Ai é... depois daquele arrocho, aí começô os contrabando pelo mato. Aí, o pessoal começaram a trazê, pelo mato, as coisa, né?"

\footnotetext{
${ }^{62}$ Entrevista com o senhor João S., em 11 de janeiro de 2007, na cidade de Foz do Iguaçu.
} 
Apesar da repressão sobre o comércio praticado pelos trabalhadores, esta atividade atraía muita gente. Em muitos casos, trabalhar na fronteira, transportando mercadorias, era mais vantajoso do que um posto de trabalho formal. O senhor João relata que seu irmão foi um dos trabalhadores que trocou de emprego, envolvendo-se com o transporte de trigo da Argentina. Por noite, ele carregava até vinte e cinco sacos de trigo. Porém, se a atividade lhe rendia mais dinheiro, também lhe trazia medo, devido às diversas situações que tornavam esse trabalho perigoso.

\begin{abstract}
"É... até esse meu irmão que trabalhô nas cataratas, um tempo, ele deixô de trabalhá lá, pra trabalhá num contrabando, aí. Ele trazia vinte, vinte e cinco saco de trigo, por noite. Assim do... da Argentina... é... tinha veiz. que tinha que trocá tiro com esses... quase morreu, muitas veiz, né? É... dava tiroteio por todo lado."
\end{abstract}

Para dona Crispina, comprar mercadorias, na Argentina, a fim de vender em Foz do Iguaçu, representava, antes de tudo, uma estratégia a mais de sobrevivência conjugada com outras formas de trabalho: "lavava roupa, ia na Argentina e assim nóis se virava”. Para o senhor Carlos e a senhora Militona, este trabalho foi uma forma efetiva de enfrentar o desemprego. Havia, também, aqueles que enxergaram, nessa atividade, uma oportunidade de tornarem-se donos de seu próprio trabalho, sem ter que responder a um patrão. Foi assim que o senhor João descreveu o trabalho de seu irmão:

\footnotetext{
“O meu irmão trabalhava pra ele mesmo. É... então, pra ele memo. Ele chegava, entregava, e a grana era tudo dele. Os amigo, que nem... cada qual... eles iam em cinco, sempre ele tinha um companheiro. Quatro e ele, né? Então, eles traziam vinte cinco 25 cada um, era cem. Mais tudo separado. Cada qual com vinte saco. Eles iam tudo junto, por causa de escorá os home nos artigo, né? Se precisasse. Mais eles traziam, eles vendiam tudo, cada qual cos vinte saco. Eles vendia, e o dinheiro era dele mesmo."
}

No caso do irmão do senhor João, essa autonomia mencionada dependia do trabalho em equipe. Não era possível, para uma só pessoa, atravessar a fronteira com toda a 
mercadoria. Cada homem carregava uma carga de 25 quilos de farinha, para fechar o volume encomendado. Segundo o senhor João S., a mercadoria trazida por seu irmão e seus respectivos companheiros era destinada, principalmente, ao comerciante local: "Era comerciante miúdo. Só que eles arrematavam o que eles traziam. [...] eles pediam mais trigo. O que vinha, vendia tudo pra eles [...]". Trabalhando em grupo, eles, provavelmente, conseguiram realizar, rapidamente, entregas de grande quantidade, solicitadas pelos comerciantes locais.

Encarado como estratégia de sobrevivência, o fornecimento de mercadorias argentinas, em Foz do Iguaçu, se tornou insustentável para a maioria dos trabalhadores, ao longo da década de 1970. As dificuldades para enfrentar a rigorosa repressão fizeram a senhora Militona desistir de continuar fornecendo produtos aos vizinhos e comerciantes do Porto Meira. A blitz da Marinha levou o senhor Carlos a refletir sobre o fato de que não era aceitável, para ele, trabalhar sob a ameaça de ser preso. Para o irmão do senhor João, não foi diferente. Sua "autonomia" começou a cobrar um preço muito alto. Segundo o senhor João: “[...] Aí, ficô muito perigoso, mataram uns amigo deles. Aí, ele ... ele parô [...]”.

Os relatos dos trabalhadores sugerem que o contrabando realizado na fronteira com a Argentina ocorria para atender às demandas de moradores e do comércio local de Foz do Iguaçu. Trabalhando para eles mesmos, como observou o senhor João S., esses homens e mulheres dominavam todo o processo de trabalho. Eles faziam as compras na Argentina, diretamente com lojistas e comerciantes. Em Foz do Iguaçu, as mercadorias eram trazidas sob encomenda e entregues diretamente ao cliente, fosse ele comerciante, vizinho, gerente de algum hotel ou restaurante. Neste sentido, parece válido afirmar que a prática desse contrabando foi vivida sem culpa, pois foi realizada por esses trabalhadores como uma atividade legítima e justa. Estes relataram suas experiências como estratégias legítimas de trabalho, que foram sendo transformadas em crime pela ação repressiva do Estado. 
Contudo, esse sentimento não acompanhou suas narrativas, quando o assunto envolvia o contrabando de mercadorias na fronteira com o Paraguai ${ }^{63}$. Alguns entrevistados indicaram que, no final da década de 1960, havia uma grande movimentação de trabalhadores locais em torno do contrabando de café. Segundo o senhor Carlos, com a decadência da exploração de madeira $^{64}$, na cidade de Foz do Iguaçu, o contrabando de café passou a ser uma ocupação para muita gente, na cidade:

"Tinha [gente], mas... e como tinha! Dava muito dinheiro, isso aí. E o pessoal, de noite, na correria, né? caminhão velho andando pelo mato, picadão e correndo com bolsa nas costa... E muita gente se virou com isso aí. Teve gente que aproveitou, teve gente que ficou na mesma ou até pior, mas dava serviço pro pessoal que dava trabalho e dava serviço pras autoridades - né? -, exército, na correria, atrás." [Grifos meus].

O contrabando de café, na fronteira com o Paraguai, foi, no entendimento do senhor Carlos, uma estratégia que permitiu que os trabalhadores sobrevivessem, diante do fechamento das madeireiras, pois, como ele mesmo disse: "muita gente se virou com isso aí”. Mas, por outro lado, esse contrabando não foi encarado apenas como uma forma temporária de trabalho.

${ }^{63}$ Cabe um paralelo com os estudos de Edward Thompson, acerca do que foi chamado "Economia Moral" da multidão, durante os séculos XVII e XVIII, na Inglaterra. Embora, lá, tenha sido um processo mais abrangente de mercantilização de todas as relações sociais existentes, resultando na criminalização de práticas comuns e, até então, consensuais como a respiga, o recolhimento de lenha nos bosques, a caça e a pesca, empresta um sentido para pensarmos como os trabalhadores constroem seus próprios valores morais - do que é lícito e do que é ilícito - a partir de necessidades materiais, e também como se desapegam de determinadas crenças e valores, sob intensa e sistemática repressão e grande pressão ideológica. (THOMPSON, 1998).

${ }^{64}$ A exploração e exportação de madeira para Argentina foi uma atividade econômica que caracterizou a história de Foz do Iguaçu, desde sua fundação até o final da década de 1960. A decadência do sistema obragero, ocorrida entre as décadas de 1930 e 1940, não implicou o fim da exploração da madeira, na região. A frente de colonização agrícola, incentivada pelo governo brasileiro, trouxe, para a região, diversas indústrias de exploração e exportação da madeira como: Carlos Sbaraini S/A, Industria e Comércio Amambahy e Industrial Madeireira Paraná Ltda. Os dados do IBGE indicaram que, ao final da década de 1950, 70\% dos estabelecimentos industriais eram ligados à indústria extrativista vegetal. Estas madeireiras dirigiam toda a sua produção ao mercado argentino. Os fatores que explicam o declínio desta industria, em Foz do Iguaçu, segundo a análise feita por Silva (2000, p.98), deve-se ao avanço da ocupação agrícola, que começava a constranger a exploração extrativista, e ao esgotamento das reservas naturais. A madeira se tornava cara porque exigia que se avançasse, ainda mais, para o leste, distante das industrias localizadas nas margens dos rios Iguaçu e Paraná. 
Logo no início da descrição do contrabando de café, o senhor Carlos fez questão de frisar: "Dava muito dinheiro, isso aî". Atravessar café do Brasil para o Paraguai representava, também, uma oportunidade de melhorar de vida, rapidamente. Entretanto, tratava-se de uma atividade arriscada, sem garantias e envolvida pelo temor constante de ser preso pelo Exército ou a Marinha. Para aproveitar essa oportunidade, era preciso enfrentar o medo, esgueirar-se, correr com cargas de café nas costas, durante a noite, pela matas das barrancas do rio Paraná.

Diferentemente do comércio fronteiriço, o transporte de café era considerado contrabando não somente pelo Estado, mas também pelos próprios trabalhadores. Contudo, era uma atividade bastante concorrida, principalmente, em períodos marcados por declínio ou estagnação das ocupações. Mesmo considerada ilegal, era uma atividade recorrente e alternativa para os trabalhadores.

O senhor Eufrásio ${ }^{65}, 77$ anos, que veio do Paraguai, na década de 1960, para morar em Foz do Iguaçu, também se lembra das manobras para driblar a fiscalização do Exército brasileiro:

"Na época, tinha contrabando de café que é levado para o Paraguai [...]. Então, [...] essa gente carregava uma caminhoneta velha, assim, cinco ou seis sacos e vinha aqui, nessa entrada aqui, e me entra isso aí. O quartel ia atrás, e era sargento... andava atrás do café. Então, a caminhoneta ia lá pro o porto oficial ${ }^{66} l$, a... a... o quartel atrás dele... E isso tá passando lá, no Porto Belo ${ }^{67}$, um, dois, três carreta de café. Pegaram aqui - né? -, café seis, cinco saco, só. E o grande passa lá. Assim fazia."

\footnotetext{
${ }^{65}$ Entrevista com o senhor Eufrásio, em 26 de janeiro de 2007, na cidade de Foz do Iguaçu.

${ }^{66}$ O Porto Oficial é o porto controlado pela Capitania Fluvial do Rio Paraná, naquela época conhecida como Capitania dos Portos. Em 6 de março de 1933 foi instalada, em Foz do Iguaçu, a Delegacia da Capitania dos Portos do Estado do Paraná. Em 20 de novembro de 1940, foi elevada à condição de Capitania de Terceira Classe, com o nome de Capitania Fluvial dos Portos do Rio Paraná, pelo Decreto n $6.530\left(\mathrm{Bol} . \mathrm{MM} \mathrm{n}^{\circ}\right.$ 50/1940). Pela Portaria no 0843, de 27 de dezembro de 1994, do Ministro da Marinha, voltou à denominação de Capitania Fluvial do Rio Paraná. O Porto Oficial localiza-se, desde sua criação, na barranca direita do rio Paraná. Disponível em: http://www.mar.mil.br/cfrp/historico.htm. Acesso para consulta em 12 dez. 2008.

${ }^{67}$ Este porto foi identificado, nos relatos, como um dos principais pontos de contrabando de mercadorias para o Paraguai, pelo rio Paraná. Sua localização é incerta, pois não encontrei mapas que o identificassem com precisão.
} 
Este relato feito pelo senhor Eufrásio ajuda a esclarecer a diferença entre o contrabando praticado no Porto Meira (na fronteira com a Argentina) e o realizado na fronteira com o Paraguai, pelo Porto Belo. A quantidade de café atravessada para o Paraguai era medida em toneladas. Se, na primeira operação, o irmão do senhor João e seus amigos atravessavam cem quilos de farinha de trigo, da Argentina para Foz do Iguaçu, na segunda operação, três carretas carregadas de café eram despachadas para o Paraguai.

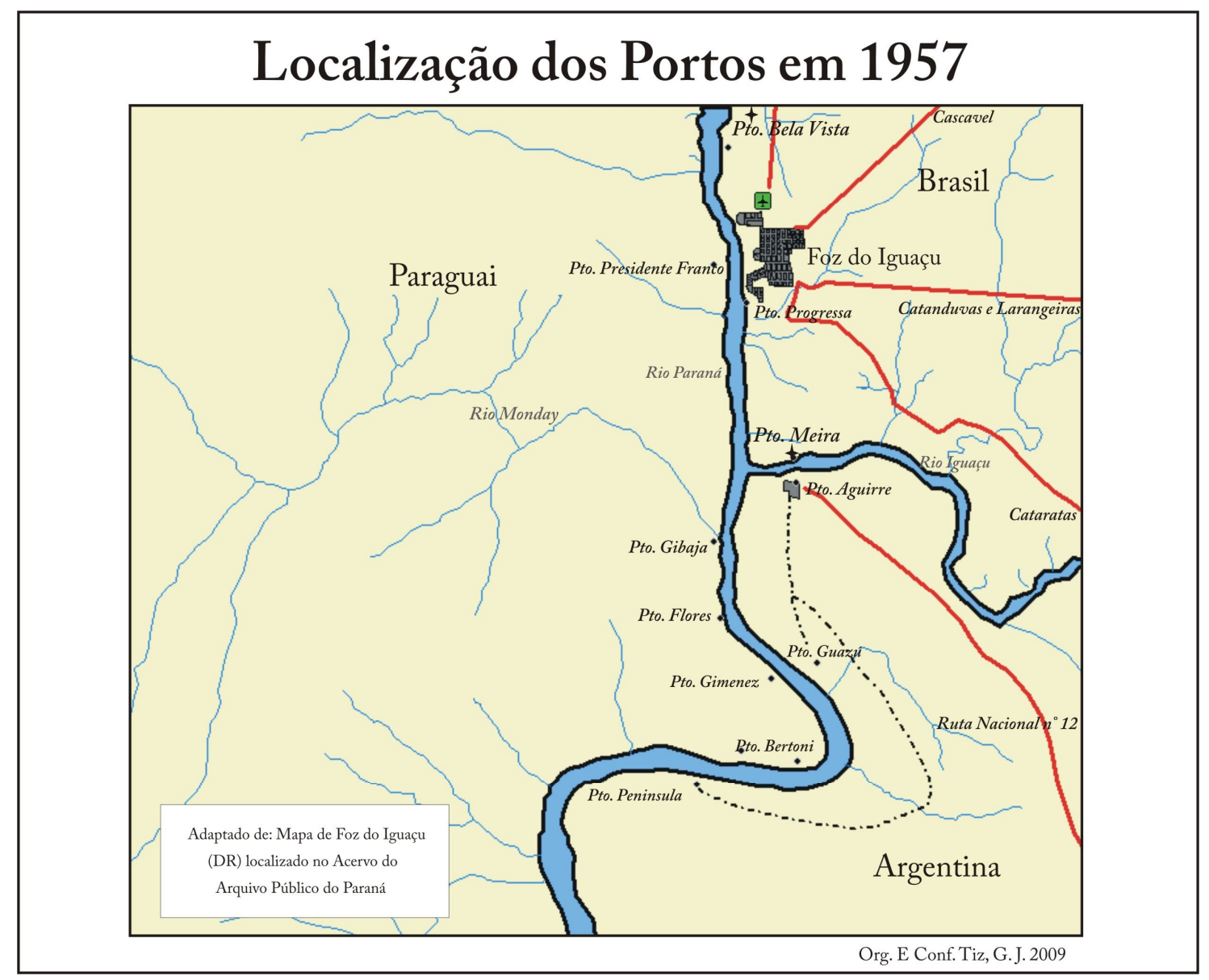

MAPA 5. Localização dos portos da Tríplice Fronteira em 1957.

Fonte: Acervo de Mapas do Arquivo Público do Paraná. 
Também para o senhor Erasmo ${ }^{68}, 61$ anos, que chegou em Foz do Iguaçu, no ano de 1966, o contrabando foi interpretado como uma atividade bastante comum nessa cidade.

\begin{abstract}
“[...] E o povo daquela época, todo o povo era contrabandista: todos, todos, todos comprava e vendia. Era café, de cá pra lá, e uísque, de lá pra cá [risos]."
\end{abstract}

Talvez, o traço mais claro que separa esse tipo de "contrabando" dos demais, na lembrança dos trabalhadores, resida no fato de que era organizado em grande escala. Os trabalhadores eram "empregados" nesse serviço. Não negociavam a compra e a venda da mercadoria. Constituíam, apenas, uma força de trabalho, contratada para efetuar o transporte do café. A esse respeito, o senhor Erasmo conta que muitas pessoas que trabalhavam nas roças, durante o dia, "empregavam-se" no transporte de mercadorias, durante a noite. Embora a atividade fosse considerada ilegal, havia justificativa para a participação dos trabalhadores nela. Estavam "trabalhando".

[...] trabalhava na roça; trabalhava na roça e, à noite, se virava pra ganhá mais. [...] Era dureza. Trabalhava o dia inteiro e a noite inteira. Só que não era direto - né? -, assim, todo dia, todo dia; era só de vez em quando, né? Passava, às vêis, uma semana, uma mêis, de repente, dois ou três dia - né? -, ou uma semana... Era o impedimento - né? -, conforme a época." [grifos meus].

Visto desse prisma, o contrabando realizado com o Paraguai, geralmente, era feito em grande escala e incorporava, hierarquicamente, diferentes estratos da sociedade local,

\footnotetext{
${ }^{68}$ Entrevista com o senhor Erasmo, em 9 de janeiro de 2007, na cidade de Foz do Iguaçu
} 
diversificando-se em função das mercadorias que eram transportadas. Nesse contexto, o contrabando de café ${ }^{69}$, diferentemente do contrabando de produtos da Argentina, não foi uma iniciativa de pequenos comerciantes ou dos trabalhadores de Foz do Iguaçu. Tratava-se de uma operação maior, na qual alguns trabalhadores engajaram-se de maneira subordinada. A rigor, todas as vezes que os entrevistados se referiram ao transporte de mercadorias como uma atividade ilegal, mencionaram o Paraguai.

De qualquer modo, o comércio, na fronteira, foi absolutamente essencial para muitos trabalhadores. O tempo vivido e lembrado pelos entrevistados estruturou-se, em grande medida, num tipo de economia que oscilou entre os campos da legalidade e da ilegalidade. Em função disso, os que falaram sobre esse assunto trouxeram à tona o fato de que esse tipo de comércio não é recente e nem decorre de tratados entre o Brasil, Argentina e Paraguai. O caráter ilegal imputado às formas de funcionamento da economia local vem de longa data, desde a interferência militar, na formação de Foz do Iguaçu. E, como estudos mais recentes têm indicado, a realidade vivida pelos trabalhadores que entrevistei encontra paralelo junto a muitos trabalhadores que, atualmente, ganham a vida como "sacoleiros" e "laranjas" (RABOSSI, 2004; CARDIN, 2006; SILVA, 2008). Enfim, vender e comprar mercadorias dos argentinos e paraguaios não era uma estratégia para burlar a lei. Era uma alternativa de trabalho e de sobrevivência para aqueles que viviam em Foz do Iguaçu.

\footnotetext{
${ }^{69}$ De acordo com Menezes (1987, p.26), o grande volume de contrabando de café para o Paraguai constituía uma grande operação de fuga de impostos. No Paraguai as taxas sobre o produto eram muito vantajosas se comparadas com as do Brasil. Assim, o café entrava como contrabando, no Paraguai, para, mais tarde, retornar ao Brasil como produto importado pelo regime aduaneiro especial "drawback".
} 


\subsection{Itaipu: uma oportunidade que não se realizou para todos os trabalhadores.}

A prática do contrabando, como era conhecida pela maioria dos trabalhadores entrevistados, começou a deixar de existir, no mesmo período em que teve início a construção da Usina de Itaipu.

Para as classes dominantes, o projeto do governo federal de construir Itaipu representou uma oportunidade de crescimento, por meio de investimentos para a formação da infraestrutura necessária ao desenvolvimento do turismo. Para muitos trabalhadores, ela representou um setor da economia local capaz de criar empregos. Entre os entrevistados, foi recorrente a descrição da construção da usina como um fator de crescimento da oferta de empregos, na cidade. Esse crescimento não estava ligado, exclusivamente, aos postos de trabalho, na obra. A construção da usina impulsionou, significativamente, o crescimento dos setores comercial e de serviços. Entre 1974 e 1979, o número de estabelecimentos comerciais subiu de 258 para 1.203 (FOZ DO IGUAÇU, 1980). A construção civil, também, foi impulsionada, pela necessária ampliação da oferta de infraestrutura exigida para acomodar o grande contingente de trabalhadores que aportaram na cidade, a partir de 1974. O número de habitações construídas, entre 1974 e 1979, quadruplicou, subindo de 4000 para 16.061 unidades (FOZ DO IGUAÇU, 1980).

Contudo, para além da questão do emprego, a construção da Usina Hidrelétrica de Itaipu foi avaliada de maneira controvertida pelos trabalhadores entrevistados. Nas lembranças destes, as expectativas daqueles que moravam em Foz do Iguaçu, em relação à construção, foi acompanhada pelo medo e pela dúvida de seus efeitos positivos sobre a cidade. O casal João, 76 anos, e Zélia ${ }^{70}, 68$ anos, se lembrou que havia grande polêmica em

\footnotetext{
${ }^{70}$ Entrevista com o senhor João C. e dona Zeni, em 30 de janeiro de 2008, na cidade de Foz do Iguaçu.
} 
torno da construção: "uns diziam assim: 'agora vai arruíná, agora vem os bandidos"”. O senhor Carlos se lembra de que havia forte desconfiança de que ocorreria com Foz do Iguaçu o mesmo fenômeno que atingiu outras cidades, onde foram construídas barragens.

“[...] pensava que, com tudo que foi feito pra construção da Itaipu, que ia virar em nada; que ia se tornar uma cidade-fantasma, como muitas outras, que, em outros lugar que foi feito barragem, a cidade virou cidadefantasma. Pensavam isso aí."

$\mathrm{Na}$ lembrança de muitos trabalhadores, a Itaipu foi responsável pelo aumento do custo de vida, na cidade. A senhora Ernestina $?^{71}, 60$ anos, avaliou que a vida dos trabalhadores em Foz do Iguaçu se tornou muito difícil desde o início da construção.

"[...] a vida pra quem morava em Foz do Iguaçu e vivia do turismo foi terrivel, porque Itaipu alugava e pagava melhor. Era difícil achar casa pra você alugar, e não se achava; tinha que pagar um absurdo, porque Itaipu pagava muito bem, encareceu muito o custo de vida, inclusive é... até nas lojas, chegou um determinado momento em que eles não estavam preocupados se a população em geral, que trabalhava com turismo, é... tinha possibilidade de comprar, não tavam nem aí. Por que? Porque o pessoal de Itaipu comprava. Itaipu trouxe muita gente, muita gente de muito dinheiro, é... Como a necessidade deles era muito grande, a demanda era muito grande de casa... [...] foi terrível! E chegou um momento em que eu, como moradora de Foz do Iguaçu, como eu, como muitas outras pessoas, nós tínhamos que ir a fazer rancho, em Santa Terezinha, ou lá mais pra frente, São Miguel, porque tudo era em função do salário ou de quem ganhasse o salário de Itaipu [...]"

\footnotetext{
${ }^{71}$ Entrevista com dona Ernestina, em 22 de março de 2007, na cidade de Foz do Iguaçu.
} 
A chegada de, aproximadamente, 20 mil trabalhadores, na cidade, muitos acompanhados de suas famílias, certamente fez os preços, em geral, aumentar, particularmente dos aluguéis, já que a procura transbordou, de imediato, a oferta de habitações. Tal situação tornou-se um drama para muitos trabalhadores de Foz, que se viram impossibilitados, inclusive, de conseguir a casa própria, já que a especulação imobiliária campeou solta. Tal fato imprimiu um forte registro, na memória dos trabalhadores, como no caso do senhor Joaquim ${ }^{72}$.

"Naquele tempo, a procura de casa pra você alugá era muito grande, não achava. Pra comprá, nem se fala; era muito grande e caro. Era muito caro um terreno, era muito caro um aluguel de casa... era difícil".

Até o início da construção da usina, os trabalhadores conjugavam o trabalho assalariado em olarias, madeireiras, serrarias e hotéis com atividade agrícola de subsistência. Esse modo de viver foi drasticamente modificado, a partir de 1974, quando teve início a construção da barragem.

O senhor Erasmo ${ }^{73}, 61$ anos, falando como alguém que nasceu e aprendeu a trabalhar no campo, sabe que a construção da Itaipu alagou terras de muitos colonos e tornou impraticável a atividade agrícola e pecuária de inúmeras famílias. Além disso, ele disse que as oportunidades de emprego criadas por Itaipu eram escassas para quem só tinha habilidades relacionadas ao trabalho no campo.

Para muitos trabalhadores, a experiência do emprego, em Itaipu, foi, também, paradoxalmente, uma experiência de desemprego. Com o avanço das obras da construção da

\footnotetext{
${ }^{72}$ Entrevista com o senhor Joaquim (nome fictício), em 22 de março de 2007, na cidade de Foz do Iguaçu.
} 
Usina, os colonos que viviam na região foram expropriados de suas terras, e o trabalho no campo, praticamente, se extinguiu (SCHMITT, 2008). Objetivamente, Itaipu provocou o alagamento de uma região que afetou muitas cidades do Oeste do Paraná. A água cobriu, aproximadamente, 111 mil hectares de terra.

As estatísticas a respeito da população de Foz do Iguaçu indicam que o decréscimo dos residentes no campo, entre o final de 1970 e o início da década de 1980, período do alagamento das terras, foi semelhante à queda constatada no Estado do Paraná (IPARDES, 1984). Mas os trabalhadores que "saíram" do campo perceberam este fato como singular, responsabilizando Itaipu.

A cidade viveu um acelerado processo de urbanização, que transformou antigas áreas rurais em novos bairros, para acomodar a crescente população, atraída pela obra ou expulsa pela formação do lago. Segundo levantamento feito pelo IPARDES (1984a), entre os anos de 19874 e 1982, o poder público municipal de Foz do Iguaçu aprovou a abertura de, aproximadamente, 79 loteamentos urbanos. Antigas áreas rurais, como Rincão São Francisco, Jardim São Paulo, Porto Meira e Três Lagoas, foram, rapidamente, ocupadas por habitações populares. Nesse período, a vida, na cidade, mudou drasticamente. Concomitantemente, cresceram, também, o número de áreas ocupadas por habitações precárias, fenômeno resultante, em grande medida, do aumento do custo de vida, da especulação imobiliária e do acelerado crescimento demográfico. Em 1977, o governo municipal de Foz do Iguaçu já implementava projetos de desfavelamento (FOZ DO IGUAÇU, 1980, p.38), na cidade.

De maneira geral, os estudos sobre esse processo de mudança sugerem que essas favelas eram formadas pela população excedente, que não foi absorvida pela construção da usina. Mas, para muitos agregados e meeiros que trabalhavam na zona rural, as favelas podem

\footnotetext{
${ }^{73}$ Entrevista com o senhor Erasmo, em 9 de janeiro de 2007, na cidade de Foz do Iguaçu.
} 
ter sido a única alternativa de moradia, diante da especulação imobiliária que assolava a cidade. Muitos desses trabalhadores foram expulsos das terras em que produziam, para que estas se tornassem novos loteamentos urbanos. Essa situação foi vivida por dona Margarida, 62 anos, e outras 10 famílias que trabalhavam no cultivo de hortelã e soja, no Rincão São Francisco, quando este ainda fazia parte da área rural do município. Eles produziam e pagavam $10 \%$ ao dono da terra. Mas, a partir de 1976, foram expulsos da terra, e, sem alternativas, as famílias se separaram e foram morar nas favelas da cidade. Entre 1976 e 1979, a família de dona Margarida foi morar na favela Monsenhor Guilherme, às margens do rio Paraná.

Durante 24 anos, a senhora Margarida trabalhou derrubando matas e plantando. Em nenhum momento de sua entrevista, ela mostrou qualquer ressentimento em relação à vida dura que, certamente, enfrentou, ao longo de toda a sua trajetória. De algum modo, a rudeza do trabalho e da vida no campo era tolerável para ela:

\footnotetext{
"Nosso trabalho, aqui, foi muito bom; durante nóis morou no sítio, a gente plantava, colhia, todo mundo tinha vida digna; muito bom, maravilha, porque nóis vivia aqui, era 10 famílias ... nóis tivemo nossos filhos, criamos, educamos; todo mundo rezava junto, caminhava junto."
}

Esse mesmo sentimento não corresponde à sua narrativa sobre a vida na cidade. Seu relato sobre o período em que viveu na favela revela como essa experiência foi uma violência contra seus padrões de dignidade:

"Deus o livre! Foi difícil, muito difícil, porque você imagina aquela pessoa que nunca morou na cidade, e ir pra cidade... que era os ranchinho, não tinha água, que 
na favela Monsenhor Guilherme e do cemitério, aqui de Foz, só tinha uma torneira de água; todo mundo buscava água pra beber e ainda lavar roupa e fazer tudo. Era tudo muito difícil! E aonde nóis morava, tinha um poço; também tinha um poço e, nesse poço, onde as crianças pegava a água, uma água salgada, sem tratamento, sem nada... e a gente vivia ali. Foi difícil, Deus o livre!".

O crescimento da cidade produziu mudanças no modo de vida dos trabalhadores, que tiveram que enfrentar, entre outros problemas, um mercado de trabalho muito competitivo. A mesma construção que criou emprego também destruiu modos de viver e de trabalhar. Desse modo, há recordações sobre esse tempo, que interpretam o período da construção de Itaipu como prejudicial ao mundo dos trabalhadores. De maneira geral, essas leituras apresentam argumentos que relativizam a positividade dos "novos" empregos, indicando que, naquela época, Foz foi "inundada" também por "novos" trabalhadores.

Falando sobre sua trajetória de vida, o senhor Carlos disse que começou a trabalhar cedo, a partir dos oito anos, vendendo verduras e fazendo pequenos serviços. Seu primeiro emprego "fichado", como ele mesmo destacou, foi numa serraria. Nela, ele trabalhou por dois anos. Depois disso, passou a trabalhar como pedreiro, o mesmo ofício de seu pai e de seu tio materno. Trabalhou na construção civil, em Foz do Iguaçu, por cerca de 10 anos.

O senhor Carlos disse ter trabalhado com fornecimento de mercadorias importadas da Argentina, sob encomenda, nos momentos difíceis de desemprego. Informou que a obra atraiu muitos trabalhadores de várias partes do país. Na sua interpretação, isto provocou um aumento muito grande na oferta de mão de obra, dificultando as chances de emprego para todos, não só para aqueles que vinham de fora, mas também - e principalmente - para os próprios trabalhadores que viviam na cidade. 
"[...] trabalhei em várias construtoras, na cidade. Aí, com o começo da Itaipu, a influência da Itaipu arruinou muito o serviço, na cidade, porque tinha muitas pessoas que vinha e não conseguia fichar e trabalhava a qualquer preço. Tinha muita gente. [...] É que a gente já estava acostumado a ganhar um preço x e, no caso, tinha que baixar o preço do serviço pra poder competir, porque as pessoas que vinham pra Foz e não conseguiam fichar, eles tinham que voltar pra cidade de origem. Então, eles trabalhavam a qualquer preço, pra poder não voltar. Esse foi o problema que surgiu."

"A influência de Itaipu arruinou o trabalho na cidade". Esta é a memória do senhor Carlos sobre a construção da usina. A presença de grandes consórcios do ramo da construção civil, especializados na edificação de barragens e de usinas, acostumados a lidar com uma força de trabalho bastante rotinizada, frustrou as expectativas de muitos profissionais de Foz do Iguaçu, a exemplo do senhor Carlos. Sua trajetória profissional fora marcada por um tipo de formação artesanal, herdada do pai e do tio, que havia sido um reconhecido mestre de obras, na cidade. O perfil dos trabalhadores atraídos pelos grandes consórcios era de outro tipo. Não necessitavam grandes e profundos conhecimentos sobre construção, mas cumpriam tarefas já previamente planejadas e fiscalizadas por outros exércitos de engenheiros (MANARIN, 2008).

Essas expectativas, provavelmente, conflitaram, desde o início, já que o pagamento pelo trabalho era menor do que o preço costumeiro, praticado na cidade, antes da chegada dos consórcios. Foi nesse contexto que o senhor Carlos apresentou-se para trabalhar na obra. Numa construção gigantesca, como Itaipu, a divisão de trabalho era uma regra, estabelecendo 
funções bastante padronizadas. Este foi o caso quando da contratação do senhor Carlos, que preferiu trabalhar como armador ${ }^{74}$, mas só encontrou emprego de pedreiro.

“[...] aí, eu resolvi de ir também trabalhar na obra da Itaipu. Tinha o consórcio da Unicom, que tocava a obra. Aí, fui lá, mas eu não queria trabalhar de pedreiro; queria trabalhar de armador de ferragem - né? -, que eu gosto mais de fazer armação de ferragem do que trabalhar de pedreiro; faz parte do... tudo os dois são da construção civil - né? -, mais... eu preferia trabalhar de armador. Aí, eles olharam a minha carteira, disseram: nós não tamo fichando armador; você quer fichar de pedreiro? Aí, eu resolvi de fichar de pedreiro."

No início, o senhor Carlos estranhou a rotina de trabalho. Após realizar o teste prático, começou a trabalhar ao lado de centenas de pessoas. Mas o estranhamento já iniciava, ao sair de casa. Pegava quatro conduções para chegar a Itaipu. Para almoçar, era outra "correria", e, para ir embora, "se cochilasse, perdia a condução". A vontade de sair do emprego recém começado era grande e crescia cotidianamente. Decidiu ficar, pelo menos, 90 dias, para não "sujar" sua carteira de trabalho. Ficou os 90 dias e acostumou-se à "correria". Ficou mais tempo.

Aposentado, desde 2001, o senhor João H. $.^{75}, 62$ anos, trabalhou para o Consórcio Unicon $^{76}$, à época da primeira fase de construção de Itaipu. Falando de seu trabalho, ele se referiu, também, ao intenso ritmo estabelecido na barragem.

\footnotetext{
${ }^{74} \mathrm{O}$ senhor Carlos se refere ao trabalho de armador de ferragens, na construção civil: preparam a confecção de armações e estruturas de concreto e de corpos de prova; cortam e dobram ferragens de lajes; montam e aplicam armações de fundações, pilares e vigas; moldam corpos de prova.

${ }^{75}$ Entrevista realizada por Odirlei Manarin com o senhor João Honório Neto, em 26 de março de 2007, na cidade de Foz do Iguaçu. (Cf. MANARIN, 2008).
} 


\begin{abstract}
"O feitor encarregado escalava o peão: 'você, você e você'. Não era todo mundo. Então, escolhia, ali, uns três, quatro ou cinco, né?. Pra trabalhar só. Tinha que trabalhar, obedecer a orde, né? Se não, ia pra rua. Se não trabalhasse, ia pra rua."
\end{abstract}

Essa intensidade do trabalho marcou a experiência de muitos trabalhadores, em Itaipu. Principalmente, porque manter-se empregado, na Usina, não era tarefa fácil. Os altos índices de produtividade, contratados entre os consórcios e a Binacional, exigiam dos trabalhadores um esforço permanente nas tarefas realizadas. Além disso, se o término de uma determinada fase, na construção da usina, implicava o deslocamento de trabalhadores para a fase seguinte, tornando o trabalho ininterrupto, também causava muitas "baixas" no número dos peões, devido às demissões planejadas (MANARIN, 2008, p.69).

O senhor Valdizar, $59 \operatorname{anos}^{77}$, explica esse processo. Em 1982, ele foi transferido para o setor de transporte, pois a escavação da barragem onde ele trabalhava, conduzindo os imensos caminhões Terex, fora concluída.

\begin{abstract}
"É. Aí, ficou só a construção civil. Aí, eles aproveitaram nóis como motorista de ônibus. [...] Foi escolhido. Muitos foi embora. Aí, aqueles tinha um passado bom, limpo, lá com eles, foi transferido, e fiquei até o final."
\end{abstract}

Permanecer no emprego era um "sacrifício", porque implicava seguir uma conduta sem falhas: sem absenteísmo, no trabalho, sem acidentes e sem desobediência. Além disso, o senhor João Honório oferece uma visão de como os trabalhadores se sentiam em relação à

\footnotetext{
${ }^{76}$ O consórcio União de Construtoras Ltda foi criado, em 1975, para atuar em Itaipu. Era constituído das cinco maiores construtoras brasileiras da época: Cetenco Engenharia S.A., Companhia Brasileira de Projetos e Obras (CBPO), Camargo Correa S.A., Andrade Gutierrez S.A. e Mendes Júnior S.A.
} 
jornada trabalhada, que sempre extrapolava o que havia sido acordado, tornando as horasextras horas "ordinárias".

\begin{abstract}
“[...] É minha folga, mas tinha que trabalhar. Quando escalava a pessoa, tinha que trabalhar. E a rotina, ali, era braba, com chuva, com frio. Ali, a gente tinha vez que endurecia o dedo, assim, no tempo do frio, que ocê não conseguia nem mexer com as mãos. Mas ocê tinha que ta lá, trabalhando".
\end{abstract}

Nem todos conseguiam seguir esse tipo de conduta, narrado pelo senhor João Honório. Alguns chegavam mesmo a burlar acidentes de trabalho. Este era um dos principais motivos para as demissões, juntamente com a resistência a trabalhar horas-extras.

Mas, os sentimentos em relação à construção da usina eram contraditórios. Se Itaipu não coincidiu com as expectativas de muitos trabalhadores, havia algumas vantagens em se trabalhar lá. As famílias de empregados da usina tinham acesso diferenciado à escola, à assistência médica e à habitação. Durante o tempo em que trabalhou na construção da usina, o senhor Carlos teve a maior parte de seus filhos estudando em escola particular, paga por Itaipu. Também, era protegido por um plano de saúde que lhe deixou fortes marcas na memória, porque foi responsável pelo nascimento de mais um filho:

"[...] inclusive, nasceu o meu quinto filho, quando eu estava trabalhando lá. Aí, a minha esposa disse assim: 'você vai trabalhar hoje?' Digo: 'vou'. 'É... disse: eu acho que hoje vai nascer o teu herdeiro'. Digo: 'não, não, não se preocupe; qualquer coisa tu liga pra lá ou liga direto pro hospital que a ambulância vem te buscar'. Aí, fui trabalhar. Quando foi pelas 10 horas da manhã,

\footnotetext{
${ }^{77}$ Entrevista realizada por Odirlei Manarin com o senhor Valdizar Luis da Silva, em 26 de janeiro de 2007, na cidade de Foz do Iguaçu. (Cf. MANARIN, 2008).
} 
me comunicaram, no serviço, que a minha esposa tinha sido hospitalizada pra ter família: 'tá tudo bem, ela foi hospitalizada'. Quando foi no fim da tarde, aonde eu estava trabalhando, vieram avisar. 'A tua esposa já teve família, tá tudo bem'. Imagina: a assistência, a preocupação com o funcionário que eles tinha."

Além da assistência médica e escolar, a Itaipu oferecia, também, moradia para os seus funcionários. À época, foram construídas três vilas, próximas de Itaipu, chamadas “A”, "B” e “C”. Nas vilas "A" e "B", residiam as famílias dos funcionários contratados diretamente por Itaipu. Eram funcionários do setor administrativo e engenheiros. Na vila "C", residiam os peões contratados pelas empreiteiras. Neste caso, as casas deveriam ser provisórias, pois foram feitas de blocos de concreto, divididos, por parede e meia, em quatro residências, cobertas com telhas de zinco e forro de isopor (MANARIN, 2008, p.47). A vila "C", com cerca de 2.900 casas, oferecia dois modelos de habitação, sendo um deles de dois quartos, com $60 \mathrm{~m}^{2}$, e outro, de três quartos, com $80 \mathrm{~m}^{2}$. No total, a população residente nas vilas alcançava, à época da construção, aproximadamente, 21 mil pessoas do lado brasileiro (CATTA, 1994, p.74).

Criticando a visão ufanista sobre a construção de Itaipu, Manarin (2008).fez notar que a fixação desses trabalhadores nas vilas significava mais do que um benefício ou privilégio, com o objetivo de atrair peões de barragem e engenheiros. Vistas do ângulo das relações de trabalho, essas vilas foram estruturadas, principalmente, para garantir a realização dos níveis de produção contratados, à medida que possibilitavam maior controle e vigilância sobre os trabalhadores (MANARIN, 2008). A presença da segurança privada da hidrelétrica, nas três vilas, era a maior evidência desse fato.

Além disso, para alguns trabalhadores, havia inconvenientes em morar na vila "C". A esse respeito, o senhor Carlos argumentou que "ganhou" casas na vila "C" e do lado 
paraguaio, mas decidiu continuar onde morava, em sua própria residência, onde precisava pegar quatro conduções até a obra. Tivera ajuda de custo para manter-se, no início, mas, depois que recusou as casas na vila "C" e do lado paraguaio, perdeu essa ajuda.

\begin{abstract}
“[...] Não vou sair do que é meu pra... né? E mesmo os meus filhos, acostumado com tudo esse espaço aqui... pra eles, ia ser uma prisão, até eles se adaptar... as casa, feito um barracão, dividido, depois, em peça menor, cada barracão pra quatro família, sai da porta da casa tá na porta do vizinho... E aqui, com tudo esse espaço, aqui, eles iam pra prisão, né?. Eu, pelos meus filhos, não saí daqui."
\end{abstract}

A padronização e a racionalização do uso do espaço, características da vila operária, representaram, para o senhor Carlos, uma forma de aprisionamento que ele, prontamente, recusou. Ele nasceu em Foz do Iguaçu, em 1946, e estava acostumado a morar nas casas com quintais amplos o suficiente para manter uma pequena horta ou em chácaras. No espaço da chácara que herdou de seu pai, o senhor Carlos vive, ainda hoje, numa pequena casa de madeira, sem muito conforto, se comparada às casas de alvenaria. No entanto, neste ambiente rústico, ele mantém sua identidade, preservando os modos de viver e morar que conheceu com seus pais e seus avós.

Muitos trabalhadores de Itaipu não tinham condições para morar nos bairros já estruturados da cidade, em função da especulação imobiliária. Principalmente, aqueles que vieram de fora da cidade e que não aceitaram morar na vila "C" ou nos alojamentos do lado paraguaio, formaram seu próprio bairro, em Foz. Envolvidos, diuturnamente, com o trabalho na obra e isolados, geograficamente, numa região periférica da cidade, estes trabalhadores construíram suas moradias modestas e lutaram para promover os melhoramentos no bairro. 
Um desses bairros é o Morumbi, conhecido, à época, como bairro de peões de Itaipu. O senhor Avimar ${ }^{78}, 55$ anos, chegou em Foz do Iguaçu, no ano de 1977, para trabalhar na construção da barragem. Trabalhou lá, durante dez anos. Foi demitido, em 1987, quando foram concluídas as obras do setor no qual trabalhava. Depois disso, reuniu suas economias, montou uma pequena lanchonete, no bairro onde mora até hoje, o Morumbi. Vive neste bairro há, aproximadamente, 30 anos, e acompanhou seu crescimento, participando de muitas lutas por melhoramentos.

O senhor Avimar disse que, no final da década de 1970, não havia lugar para morar, na cidade. Inicialmente, ele morou na vila "C"; mas logo comprou um terreno, cujo pagamento seria dividido em cinqüenta prestações, num loteamento feito na região do São Francisco: "Parcelado. Em 50 vezes, [risos] parcelado. Fui pagando, fui pagando e, depois, fui construindo, devagarzinho." Esse bairro nasceu no auge da obra de Itaipu. O loteamento foi, neste sentido, ocupado, fundamentalmente, por pessoas motivadas pela expectativa de encontrar emprego, na cidade, em função da construção da usina, bem como por aqueles que eram demitidos e permaneciam em Foz.

\begin{abstract}
"Porque, aqui, na realidade, quando começou esse bairro, o povo entrou de baixo de lona tudo. Esse bairro foi um bairro colonizado por... um bairro popular mesmo, como diz a história, que você anotou aí: é um bairro popular mesmo. Foi, foi habitado por pessoas humildes, pessoas simples, que veio em busca de trabalho, pessoas que vem pra aventurar mesmo, pro tudo ou nada. Então, foi bastante difícil no começo..."
\end{abstract}

\footnotetext{
${ }^{78}$ Entrevista com o senhor Avimar, em 26 de janeiro de 2007, na cidade de Foz do Iguaçu.
} 
Nesse sentido, pode-se dizer que Itaipu era uma cidade dentro de Foz do Iguaçu. Primeiro, porque a barragem onde os peões trabalhavam ficava muito distante do núcleo urbano de Foz do Iguaçu. Segundo, porque as vilas onde moravam os peões e funcionários administrativos constituíam um lugar com regras próprias, além de ficarem distantes do núcleo urbano de Foz. Além disso, para quem não trabalhava na Itaipu, tendo que pagar aluguel, numa conjuntura de alta especulação imobiliária, e morar em locais sem qualquer infraestrutura, a vila $\mathrm{C}$ parecia um privilégio.

Mas as vilas expressaram apenas uma face da segmentação do espaço urbano produzido a partir da construção da usina. O surgimento de grandes loteamentos, para abrigar a nova população, contribuiu, também, para demarcar os espaços da cidade ocupados pela população que para esta migrara, em função da construção da hidrelétrica. O senhor Avimar relata que, no Morumbi, a vida da população do bairro era bastante isolada do restante da cidade:

"Não tinha muito contato, pelo, pelo fato de que a gente chegou, já foi fichando na barragem. Então, o que acontece? Saía de casa cedinho, com escuro, e voltava à noite. Contato maior era aos domingos, aos fins de semana, quando tinha uma folga. Mas era com as pessoas as vezes vinda de fora também, porque, praticamente, nos bairros, tinha muito pouca gente daqui mesmo. Porque foi colonizado, assim, de repente; esse bairro inchou de uma tal maneira, que o povo era tudo vindo de fora, na época que chegou aqui. Então, não tinha contato, contato político, que nem como a gente tem hoje, conhece todo mundo, o prefeito conhece a gente, os secretários, os deputados, tudo. Aquele tempo, isso aí não existia. A gente era um pouco isolado, nessa parte." 
Contudo, o mesmo sentimento, em relação à Itaipu, que revelou um período vivido de muitas dificuldades, marcado principalmente pelo trabalho duro e pelo esforço para manter-se empregado, também reconheceu o tempo passado nessa construção com saudades. O que merecia ser lembrado era o emprego. Para o senhor Avimar, que vivia (e ainda vive) num bairro "habitado por pessoas humildes", o desemprego e a violência sempre foram problemas muito reais, experimentados no cotidiano.

"Então, calou desespero: uma boa parte do povo foi embora, outras ficou por aí, se mantendo... é... fazendo... puxando uma muambinha do Paraguai. É por aí... é se virando... Mas, realmente, hoje, a situação financeira de Foz do Iguaçu pros moradores, aqui, não é boa, não, não é boa. Piorou muito, muito, muito, muito mesmo [...] Porque você sabe que o desemprego também traz violência, né?. Então, na época, todo mundo empregado, que a violência era bem menos."

O final da obra trouxe o desemprego e o caos social para a cidade, na avaliação do senhor Avimar. Embora existisse uma enorme propaganda afirmativa dos benefícios trazidos por Itaipu, evidenciados, principalmente, pelo pagamento dos royalties ${ }^{79}$ realizados, desde o ano de $1991^{80}$, o senhor Avimar sugere que estes recursos não reverteram o quadro de desemprego, instalado após o término da obra:

“[...] quando acabou a obra, foi um Deus nos acuda.

Então, hoje, é o que eu falo, deveria assim: os royalties de Itaipu tinha que ser mais bem aplicado, né? Ser

${ }^{79}$ Royalty é um "valor pago ao detentor de uma patente ou criador de obra original pelos direitos de sua exploração comercial". (SANDRONI, 1987, p.386). Dentre os dezesseis municípios que tiveram terras cobertas por água, Foz do Iguaçu perdeu mais de $1 / 4$ de todo seu território.

${ }^{80}$ Os royalties de Itaipu foram estabelecidos, pelo governo federal, por meio do pelo Decreto $\mathrm{N}^{\circ} 1$, de 7 de fevereiro de 1991. 
aplicado, ter um destino específico pra moradias, pra indústrias, né? [...] Então, Itaipu deixou essa sequela, em Foz do Iguaçu; infelizmente, deixou."

Nesse contexto é que os sentimentos de muitos trabalhadores, em relação à construção da Itaipu, se mostraram controvertidos. Ao mesmo tempo, essas críticas expuseram as dúvidas dos trabalhadores em relação ao turismo e à sua capacidade de gerar empregos, na cidade.

\subsection{0 turismo na perspectiva dos trabalhadores.}

No Capítulo 3, foi possível discutir a fragilidade da leitura que apresenta a cidade de Foz como "vocacionada" para o turismo. Tal construção ideológica remontou à primeira visão relatada sobre as cataratas, acontecida no século XVI, pelo explorador espanhol Cabeza de Vaca. Mas já sabemos que a atividade econômica do turismo, em Foz, é bem mais recente e dependeu, inclusive, do surgimento do "turismo de massa" (BOYER, 2003), alicerçado em componentes complexos, como transportes e alojamentos.

Contudo, além de problematizar o curso "natural" do turismo, em Foz do Iguaçu, cabe, também, indagar o significado de "ser" uma cidade turística.

A relação dos trabalhadores entrevistados com essa cidade mostrou-se contraditória, sob diferentes aspectos. Quando indagados sobre sua importância, os trabalhadores identificaram, no turismo, um fator determinante do desenvolvimento e do crescimento da cidade. Em grande medida, esta percepção esteve, quase sempre, relacionada à associação feita por eles entre turismo e geração de empregos. Na fala de alguns, esta associação resultava de sua própria experiência de trabalho, e a questão se apresentava de maneira 
pragmática, como mostrou a senhora Eugênia: “... porque, se não tem turismo, não tem, não tem hotel, daí também não tem emprego. Eu também trabalhei, seis meses, em hotel”. Para outros, como o senhor Erasmo, que não trabalhou diretamente no setor, tratava-se de expor sua observação sobre a capacidade do setor em gerar empregos:

“[...] o turismo é importante. O turismo aqui é... a maior parte, aqui, tá sendo o turismo, as catarata, a ponte, os paraguaio, que a ponte é do Paraguai também, que traiz esse pessoal de fora. Esse aqui é a salvação nossa, é essa. Ah! Os hotel, que tem muitos funcionário, tem bastante. Muitas é... pessoa que trabalham em... um.... que trabalham por causa do turismo. Ele emprega muitos funcionário... é... hotel, a catarata... muitos funcionário, funcionam por isso. O Parque das Aves, que é outro, também que influi muito $[. .$.

Entretanto, quando os trabalhadores narravam suas trajetórias de vida e trabalho, na cidade, a relação entre eles e a cidade turística ganhava contornos conflituosos. Ajuda a entender esse sentimento o fato de que um dos problemas presentes na definição de "cidades do tempo livre" reside em que, definitivamente, não são "cidades do tempo livre". Qualquer cidade considerada "turística" ou "balneária" sustenta-se no trabalho de um exército de pessoas, que a fazem funcionar como cidade do "lazer". Assim, o "lazer", o "ócio", o “descanso" e o "divertimento" são estruturados como um negócio. Uma cidade "turística" é, nesse sentido, uma cidade para ser desfrutada pelos outros.

Foi assim que o turismo apareceu, na fala dos trabalhadores. O turismo, como desfrute, era uma atividade para os outros. Hotéis, restaurantes, rodoviárias, avenidas, praças, táxi, aeroporto, hospitais, meios de comunicação, tudo, na cidade, está organizado, em função 
de garantir um padrão adequado de atendimento do turista. A cidade por onde o turista passa deve ser bem sinalizada, pavimentada, limpa, arborizada, acessível.

Tal cidade é bastante diferente daquela vivida pelos trabalhadores entrevistados, particularmente, para aqueles .que moram nos bairros, formados a partir do final da década de 1970, nas regiões do Rincão São Francisco ${ }^{81}$, Três Lagoas ${ }^{82}$ e Porto Meira $^{83}$. Na lembrança desses trabalhadores, a vida era muito difícil para aqueles que moravam nos bairros. Ao descrever como era a situação do Jardim Bandeirante, bairro localizado na região de Três Lagoas, a senhora Perciliana sintetizou bem a precariedade característica dos bairros populares da cidade:

\begin{abstract}
"Não tem coisas boas, banco, caixa, essas coisa, não tinha... O que nóis sofria! Não tinha posto de saúde... não tinha. Até que abriu um, ali, que era madeira; agora, já tá bem melhor. Mas naquela época, que nóis chegô aqui, não foi nada fácil."
\end{abstract}

\footnotetext{
${ }^{81}$ Região 03 - São Francisco. Localiza-se na porção leste do município. É limitado ao norte pela BR277; ao sul, pela Av. República Argentina, que o separa da Região 5 - Jardim São Paulo - e, a oeste, pelo rio Tamanduazinho, que o separa da área rural sul. Ao todo, a região é formada por 24 bairros. Nela, estão localizados o minidistrito industrial, uma subestação da Copel e algumas chácaras. Sua população é de 45.298 habitantes. Até meados da década de 1970, era uma área rural. O processo de urbanização teve início a partir da construção da usina de Itaipu.(WEBER, 2003, p.72)

${ }^{82}$ Região 01 - Três Lagoas. Localiza-se na porção nordeste do município. É limitada, ao norte, pelo Lago de Itaipu; ao sul, pela área rural; a leste, pelo município de Santa Terezinha de Itaipu, e, a oeste, pela estação de Furnas, que a separa da Região 2 - Vila C. Ao todo, é formada por 38 bairros. Sua população é de 27.123 habitantes. Até meados da década de 1970, era uma região agrícola. O processo de urbanização teve início a partir da construção da usina de Itaipu. (WEBER, 2003,p.68)

${ }^{83}$ Região 04 - Porto Meira. Localiza-se na porção sudoeste do município. É limitada, ao norte, pelo rio M'Boicy; a oeste, pelo rio Paraná; a leste, pelas avenidas das Cataratas e Mercosul, que o separa, respectivamente, da Região 5 - Jardim São Paulo e da Região 11 - Carimã; e ao sul, é limitada pelo rio Iguaçu. Ao todo, a região é formada por 32 bairros. Sua população é de 37.470 habitantes. Até meados dos anos de 1960, era uma área composta por inúmeras propriedades agrícolas. Até a construção da ponte da Fraternidade (1982), esta região abrigava a via fluvial de ligação com a Argentina, para a maioria dos moradores de Foz do Iguaçu (BR) e Puerto Iguazu (AR). O processo acelerado de urbanização desta área coincidiu com o início da construção da usina de Itaipu. (WEBER, 2003).
} 
A falta de infraestrutura apareceu como um registro forte da memória destes trabalhadores, sobre sua história na cidade. A senhora Margarida lembra que, quando chegou no bairro Morumbi, “não tinha luz nem água, [...] nóis tivemo que fazer poço”. Moradora antiga do Jardim Bandeirante, a senhora Perciliana lembra, também, que os serviços básicos de fornecimento de água e luz só foram realizados anos depois da formação do bairro:

"A luz não demorô muito; demorô, acho, que uns trêis, quatro ano, ainda [risos], que a gente tinha lampião, né? A água também. Aí, foi chegando devagazinho, né? Mais ainda levou... a gente tinha poço. Ah! Levô ainda uns seis ano pra vim água, depois daquele tempo; daí, chegô tudo."

A falta de transporte, também, foi muito lembrada pelos trabalhadores. A senhora Militona, moradora do bairro Jardim Oriente, localizado na região Porto Meira, lembra das dificuldades que tinha de enfrentar, para ir até o centro da cidade, para fazer as compras do mês: "Porque era tudo a pé. Tudo a pé. Tem que carregá nas costa as coisa, antigamente [...] depoi que veio esses ônibus”. Ela lembra, também, que, para ir trabalhar, no Hotel San Martin, ela e suas cunhadas tinham que andar mais de três quilômetros, para tomar a condução: "Trabalhei no hotel, junto com as quatro cunhada minha [...] e minha vizinha. Nóis [...] ia a pé, daqui até lá, no Boicy, pegá ônibus que vai pro lado da Catarata [...]”. A senhora Militona começou a trabalhar, no Hotel San Martin, por volta de 1974. "Naquele tempo", o Porto Meira não era servido nem de calçamento nem de transporte público. O senhor Joaquim, morador do bairro Jardim das Flores, também localizado na região do Porto Meira, lembra das dificuldades que a população trabalhadora, na década de 1980, ainda enfrentava para ir trabalhar, pois o calçamento e o transporte público chegavam, apenas, nas avenidas principais do Porto Meira. 
"Era difícil. Quando chovia, era difícil [...] quem morava aqui pra baixo, quando vinha pra ponto de ônibus, arrumava essas sacolinhas do mercado, calçava no tênis, no sapato; quando chegava no ponto de ônibus, tirava aquela sacolinha pra embarcá no ônibus... tirava aquela sacolinha pra embarcá no ônibus. Se viesse daquele jeito lá, pra embarcá dentro do ônibus, o ônibus ficava uma tristeza."

Situação muito parecida era enfrentada, igualmente, pelos trabalhadores que moravam na região de Três Lagoas, que, também, sofriam, com a falta de pavimentação e transporte. Para tomar a condução e ir para o trabalho, os moradores tinham que se deslocar até a BR277. Isso significava percorrer uma distância de um a dois quilômetros, dependendo da localização da residência em relação à rodovia. Dona Perciliana diz que saía de sua casa, no Jardim Bandeirante, e ia “[...] até na BR, de a pé”. Os dias de chuva também foram lembrados como momentos de grande dificuldade:

"[...] E o dia que chove? E o barro? Atolava! Muitas veiz, ponhava uma sacola de prástico nos pé, pra chegá lá [...] O dia que tinha barro era coisa mais triste do mundo... que não é pertinho, né? [...] É muito longe... era longe [...]."

Na lembrança do senhor Avimar, a falta de calçamento marcou, também, a vida dos trabalhadores que moravam no bairro Morumbi: "[...] a terra era horrível. Depois de 10 anos, depois de 11 anos, que foi chegar o calçamento, numa parte ainda, [...] porque, até há uns 4 ou 5 anos atrás, tinha rua sem calçar, ainda”. O sentimento do senhor Avimar, em relação às condições de vida, no bairro, era similar àqueles expressos pelo senhor Joaquim e a senhora Militona. As expressões - "era muito difícil", "era dificultoso" -, recorrentes nas narrativas, 
indicam como os trabalhadores lembram de tudo isso como experiências de sofrimento, na cidade. Algumas dessas experiências deixaram marcas indeléveis, que o tempo não apagou e que são revividas com angústia e medo de que voltem a se repetir. Foi assim que dona Perciliana se lembrou do sufoco que significou ter que enfrentar, todos os dias, o lotação, para ir trabalhar:

\begin{abstract}
"Aqueles ônibus, que parece sardinha... aí, eu não guento sardinha! Pura sardinha! E era um em cima do outro, um em cima do outro. [...] Hoje em dia, quando eu sonho que eu pego esses ônibus de novo, eu quase morro do coração! Deus ô livre! Meu Deus do céu, não era fácil, não!"
\end{abstract}

Esses trabalhadores recuperam, em suas lembranças, uma cidade muito diferente da imagem de cidade turística, veiculada pela memória e pelas propagandas oficiais. Sem serviço de água e luz e esgoto, sem calçamento, a que se revela, nas suas falas, era suja e precária. Desse ponto de vista, a situação narrada pelo senhor Joaquim e por dona Perciliana, na qual os trabalhadores tinham que "calçar" saquinhos plásticos nos pés, para poder entrar no ônibus e ir trabalhar, sem que seus calçados estivessem encharcados de lama, é simbólica da segregação espacial vivida, em Foz do Iguaçu.

Os trabalhadores não ignoram que a cidade cresceu e se desenvolveu, mas não deixam de observar, também, que esse desenvolvimento não foi orientado pelo interesse de atender as necessidades da população trabalhadora que vive nos bairros de Foz. Valendo-se de sua trajetória local de trinta anos, o senhor Avimar questionou esse modelo de desenvolvimento urbano que caracteriza a cidade turística

"São 30 anos. 30 anos são uma vida. Porque é... é... eu acho que falta muito pra ser uma cidade, ainda, bem 
organizada, pra ser uma cidade turística. Tá crescendo, muito lentamente. Cresceu o número de população, mas, hoje, a cidade, eu acho ela mal estruturada, né? Eles capricham mais no corredor turístico, ou coisa pra turista ver, mas os bairros estão um pouco abandonados. Eu não sei, eu acho que eles acham que a prioridade hoje é o turismo [...]."

No seu entendimento, uma cidade turística precisa oferecer uma boa estrutura para todos e não apenas para o turista. Morador do bairro Morumbi, o senhor Avimar fala a partir da experiência de quem vive num bairro que, desde o início de sua formação, não contava com nenhuma infraestrutura. O serviço de água tratada e encanada demorou mais de oito anos para ser oferecido, no bairro. O calçamento demorou mais de dez anos para ser realizado.

A cidade se revela, na fala do senhor Avimar, como algo mais que uma paisagem. É o lugar onde se vive, onde se mora, onde se trabalha e, neste sentido, a cidade vai muito além do corredor turístico. Os bairros onde vivem os trabalhadores, também, precisam de sinalização, de asfalto e de espaços dedicados ao lazer.

Essas narrativas desenvolvidas pelos trabalhadores permitiram identificar como o desenvolvimento urbano de Foz do Iguaçu concentrou-se nas áreas da cidade funcionais ao turismo, em detrimento dos locais de moradia dos trabalhadores. Contudo, essa segregação geográfico-social não foi a única contradição presente na relação entre estes últimos e o turismo, na cidade. Alguns relatos indicaram, ainda, que o desenvolvimento da atividade turística, em Foz do Iguaçu, foi e continua sendo vivido, pelos trabalhadores, também como exploração.

Se, por um lado, a ampliação do turismo como atividade econômica e sua conseqüente incorporação de mão de obra responderam à expectativa de emprego para muitos trabalhadores, por outro lado, traduziram-se numa experiência de segregação e exploração, na 
cidade. Na memória de dona Margarida ${ }^{84}, 63$ anos, o turismo é lembrado como uma atividade distante do seu universo social e sobre a qual ela acredita não saber muito: "Olha, não sei, porque toda vida fui pobre; morei pra cá, não sei de nada”. Desde que chegou a Foz do Iguaçu, em 1971, morou fora do corredor turístico da cidade. Em 1979, ela e o marido conseguiram comprar um terreno e construíram uma casa, no Morumbi, voltando para a região do São Francisco.

Com segurança, ela acredita que só pode falar daquilo viu, durante os anos que trabalhou no centro da cidade: “[...] o que eu vejo, o que eu alcanço, que eu trabalhei na cidade, muitos anos - né? -, trabalhei dentro da cidade, ali." Assim, partindo de sua trajetória de vida e trabalho, dona Margarida definiu o turismo como uma forma de exploração da natureza e do trabalho, na cidade de Foz do Iguaçu:

"[...] criaram um monte de casa, e um monte de casa dentro das catarata, e virou o maior comércio. Até nóis, se quiser entrar lá, que mora aqui, tem que pagar. Isso aí não é turismo, é exploração [...] Pra falar a verdade, turismo, eu não conheço nada; só vejo a exploração do turismo $[. .$.$] "$

Morando na periferia e trabalhando no centro da cidade, dona Margarida viveu, sentiu e percebeu o crescimento da cidade e o desenvolvimento do turismo, na década de 1980. Desta experiência, ela expôs, principalmente, sua leitura sobre as condições de trabalho que eram enfrentadas por aqueles que trabalhavam na rede hoteleira da cidade.

“[...] eu só vi o quê?? Nóis, que trabalhava na loja, ganhava mais que quem trabalhava em hotel; nóis não trabalhava, no domingo: era fechado. E, nos hotel,

\footnotetext{
${ }^{84}$ Entrevista com a senhora Margarida, em 22 de março de 2007, na cidade de Foz do Iguaçu
} 
trabalhava, no domingo, feriado e tudo. Pra quê? [...] Quem trabalha no hotel, aí, vem embora de ônibus imprestável, que nossos ônibus, aqui, não presta; fala a verdade, toda a lotação nossa, aqui, não vale nada; a lotação nossa, aqui, é assim, um banquinho desse tamaninho de um lado, dois banco aqui e o corredor, em pé, pra andar igual um bando de boi."

Assim, o que permanece vivo, em sua lembrança, é a rotina cansativa do trabalho nos hotéis, que não se convertia em melhores condições de vida para os trabalhadores do setor. Sem tempo para descansar, aqueles que trabalham para garantir o lazer e o ócio dos outros tinham sua jornada estendida, em função das precárias condições de transporte público, que não permitia a eles qualquer conforto, durante o percurso de ida e volta do trabalho, tal como observou dona Margarida: “Tudo de pé... aí, você vai, chega no hotel cansada, trabalha a vida inteira de pé, correndo pra lá e pra cá. Na hora de ir embora, você tem que vim de ônibus."

Essa situação era ainda pior para outros trabalhadores. Este era o caso da senhora Militona, que caminhava cerca de três quilômetros, até o ponto de ônibus, para ir trabalhar, no Hotel San Martin, como auxiliar de serviços gerais. À jornada de oito horas de trabalho, no Hotel, ela somava seis quilômetros de caminhada e uma longa lista de tarefas domésticas:

“[...] saía daqui madrugada, pa ir i podê pegá o ônibus, lá no Boicy, como disse pa você, e depoi, só vinha só de noite em casa. Tinha que tirá água do poço, chegá aqui, tirá água do poço, lavá as roupa das criança, deixá pronto, fazê janta; depoi, ia lavá roupa, de noite, depoi, pra mim me deitá." 
Na memória da senhora Militona, foi a lembrança da dura rotina de trabalho e das dificuldades, enfrentadas durante o período em que trabalhou em hotéis, que ganhou destaque, em sua narrativa. Ela conta que, depois de trabalhar 12 anos, "sempre na lavanderia, serviço geral", desenvolveu uma séria alergia. Enquanto ela relatava o drama vivido, mostrava as cicatrizes, em seus braços, provocadas pela reação aos produtos químicos com os quais lidava, em seu trabalho:

"Eu vim ficá doente; aqui, apodreceu tudo o braço assim, ó. Assim... é química. Apodreceu tudo a pele, tudo, tudo, assim. Era negócio de produto forte, e tinha proteção pa gente usá, e foi e... Não pa todos que acontece isso na pele, né? Que acontece isso na pele, né? Eu acho que minha pele é muito... é sensíve e foi... apodreceu tudo. Num podia trabalhá mais [...] num podia mais trabalhá, porque tinha que amarrar, assim, o braço tudo, pa mim podê trabalhá. Aí, eu pedi minha conta."

A perícia médica não considerou o caso da senhora Militona como uma enfermidade causada pelo trabalho. Sem condições de continuar trabalhando, ela acabou fazendo um acordo com o hotel e saiu do emprego.

“[...] pedi pro gerente, seu Mauro? Eu num agüento mai trabalhá, por causa do mo braço; e outro, meu marido também tá duente, e tenho cinco criança e já tô tirando ela fora da escola, por causa disso.[...]. Ih, muita tragédia, menina." 
Essa situação, vivida pela senhora Militona, parece não ser um caso isolado, quando se considera a observação feita por dona Ernestina ${ }^{85}, 60$ anos, guia de turismo em Foz do Iguaçu, desde 1976. Em sua avaliação sobre as condições de trabalho, no setor, ela reclamou do descompromisso dos donos de hotéis com seus funcionários:

“[...] a grande maioria dos hoteleiros, aqui, eles não querem saber se o funcionário está bem, se ele está com algum problema. São poucos os empresários que pensam em fazer um bom seguro coletivo de saúde [...] inclusive, tem muita gente que está trabalhando num hotel, gostaria de fazer uma faculdade de hotelaria e não tem condições, porque o salário é tão parco, e, principalmente, te digo, quem trabalha em reserva de hotel, quem trabalha em recepção de hotel, é terrivel [...] A lei não diz que, quando você tem não sei quantos funcionários, você é obrigado a ter um refeitório decente, você é obrigado a ter uma creche. Faz um levantamento nos hotéis, aí. Quantos hotéis têm creche pra que as camareiras, garçonetes, ou seja o que for, possam deixar seus filhos nas creches? Não tem, não é revertido [...]"

O funcionamento da rede hoteleira, como descrito por dona Ernestina, está fundado numa tradição de baixos salários, nenhum investimento em formação e qualificação de seu pessoal, e pelo desrespeito aos direitos trabalhistas. Sob esta perspectiva, a história do desenvolvimento do turismo, em Foz do Iguaçu, adquiriu outros contornos. A capacidade empreendedora dos empresários locais é traduzida em vocação para exploração da força de trabalho local.

A chamada indústria do turismo depende de um grande contingente da força de trabalho, para garantir ao turista a sensação definitiva de que está em férias. Para garantir que ele - o turista - não tenha qualquer trabalho, um exército de trabalhadores é colocado à sua

\footnotetext{
${ }^{85}$ Entrevista com a senhora Ernestina, em 22 de março de 2007, na cidade de Foz do Iguaçu.
} 
disposição: camareiras, cozinheiros, lavadeiras, passadeiras, garçons, porteiros, motoristas, recepcionistas, faxineiros, jardineiros, telefonistas, guias, instrutores. As condições de trabalho destes trabalhadores não aparecem nas fotos de divulgação do turismo, nem nas propagandas oficiais que o apontam como estratégia econômica local de geração de empregos - diretos e indiretos.

Para dona Ernestina, o turismo, enquanto atividade econômica, é um importante gerador de empregos para a cidade. Afinal, desde que a esta chegou, em 1976, vindo de Assunción (PY), ela trabalha no setor, principalmente como guia de turismo. No entanto, ela pondera, criticamente, que o desenvolvimento do turismo não reverteu em boas condições de vida para os trabalhadores do setor. Os lucros por este alcançados aparecem, em sua avaliação, como resultado da capacidade de super-exploração do trabalho:

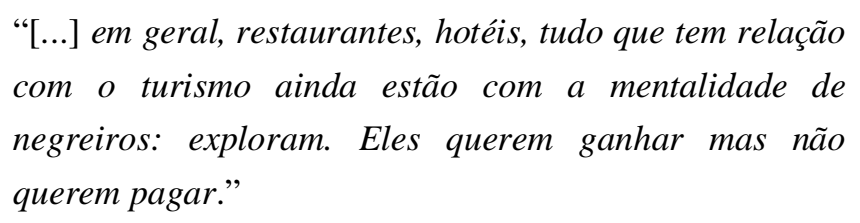

As narrativas de vida destes trabalhadores são testemunhos importantes do processo histórico de transformação que Foz do Iguaçu viveu, a partir da década de 1970. Estes relatos explicitaram os sentidos contraditórios do crescimento urbano, impulsionado pela construção da Usina de Itaipu, e da ampliação da atividade turística, na cidade, do ponto de vista dos trabalhadores.

Na compreensão dos trabalhadores, o crescimento e a diversificação do comércio, o número crescente de prédios, a pavimentação, a ampliação do espaço urbano não eram problema. De um modo ou de outro, eles guardavam esta expectativa de crescer junto com a cidade. No entanto, quando narram o caminho percorrido, os trabalhadores não deixaram de 
observar o custo social e humano que esse crescimento impôs. É neste sentido que suas memórias sobre o viver na cidade são importantes, porque expõem as contradições de um processo que está longe de ser harmonioso. 


\section{CONSIDERAÇÕES FINAIS.}

Em 2004, quando dei início à pesquisa que resultou nesta tese, o turismo já estava consolidado na cidade de Foz do Iguaçu. Dados divulgados pela Embratur apresentavam a cidade como o segundo destino mais visitado por turistas estrangeiros, entre os anos de 2004 e 2005.

Esta pesquisa não procurou negar este fato. A problematização que orientou este estudo buscou, por outro lado, discutir as percepções sobre o processo que promoveu o crescimento da atividade turística, em Foz do Iguaçu, e sua transformação em eixo do desenvolvimento da própria cidade. Dentro desta perspectiva, as questões enfrentadas, nesta investigação, centraram-se no esforço de problematizar a memória hegemônica que naturalizou aquele processo a partir do discurso sobre a vocação turística da cidade. Nesse sentido, a pesquisa caminhou na direção de explorar as contradições que permearam tal trajetória de produção e reprodução dessa memória, buscando identificar e reconhecer os diferentes sujeitos nela envolvidos.

Num primeiro momento, pude concluir que a elaboração dessa memória sobre a cidade foi produzida no calor de disputas políticas entre os grupos dominantes locais e os representantes do governo federal, responsáveis pela construção da Usina Hidrelétrica de Itaipu. A cidade de Foz do Iguaçu passaria a conviver não apenas com os efeitos da construção da barragem, mas também com a forte intervenção da Usina, no seu cotidiano. Os grupos dominantes locais se viram profundamente ameaçados, em sua autonomia. Esta realidade mostrou-se complexa para ser visualizada e estudada, dado o fato de que as classes hegemônicas lutaram entre si pelo controle e pela direção desse processo histórico que 
transformava as relações sociais na cidade, o padrão de acumulação de riquezas e a própria paisagem urbana, cuja imagem os grupos de maior influência, em luta, tentavam decalcar. Em síntese, face ao esgotamento das madeireiras, vivido nas décadas de 1960 e 1970, as classes dominantes nativas enxergaram em Itaipu o móvel da reorganização econômica da cidade pelo qual lutaram para controlar.

O produto inacabado de tais disputas esteve e está representado no turismo, visto como atividade mais importante e predominante na cidade. Vez ou outra, essa imagem sofre abalos, possibilitando avistar, por entre suas fissuras, que a vida das pessoas não está ancorada, exclusivamente, na economia do turismo. Atualmente, não são poucos os noticiários nacionais que mostram a interdição do "comércio" ilegal com o Paraguai, revelando, com isso, a paralisação de um "setor" da economia de Foz que ainda mobiliza, informalmente, milhares de trabalhadores. Quando isso acontece, mesmo que por curtos períodos de tempo, a face da cidade se mostra obtusa, intrincada. Esse tipo de complexidade, difícil de ser identificado, apreendido e discutido, foi alvo de meu interesse, nesta tese.

O tempo passado que investiguei mostrou-se matizado por diferentes percepções dos trabalhadores entrevistados. De maneira também complexa, eles problematizaram a memória oficial sobre Foz do Iguaçu, ora reivindicando-a, ora oferecendo um enredo alternativo, ora fazendo ambas as coisas, e apresentando pequenos retratos, a partir dos quais tentei construir um mosaico que expressasse o sentido da memória atribuído por eles.

Mas tentei escapar da tentação de, apenas, registrar um desenho final dessas experiências, como se fosse um caleidoscópio. Reconheço a importância social de ouvir as classes dominadas sobre os diversos processos históricos dos quais foram parte integrante. A historiografia brasileira tem assumido esse desafio, há tempos, e os resultados alcançados, em larga medida, têm contribuído para modificar nossa percepção acerca de vários pontos da 
história do Brasil. Contudo, parte dos esforços empreendidos na valorização dos sujeitos subalternos ou das classes dominadas desaguou numa operação que, via de regra, tem suprimido a noção de processo histórico, registrando a presença de tais sujeitos, na história, como únicos, arruinando o peso de outros sujeitos e classes sociais, do Estado, das instituições, enfim, daquelas estruturas econômicas e sociais a que Marx se referiu como condições históricas herdadas, sob as quais os homens constroem suas trajetórias em vida (MARX, 1988). Portanto, as experiências sociais que procurei valorizar foram encaradas como produtos de ações individuais, mas sempre referidas a quadros de valores morais, muitas vezes compartilhados e vividos coletivamente, como experiências de classe num processo histórico de lutas.

O que se refletiu, a partir disso, nos dois últimos capítulos, me leva a pensar que a memória oficial de Foz em presença, conforme revelada nas intenções, discursos, práticas e imagens apresentadas pelas classes dominantes, é um processo inacabado e pontuado de contradições vividas e percebidas pelos trabalhadores que as interpretam à luz de suas experiências naquela cidade. As memórias elaboradas pelos entrevistados indicaram a força e o poder de convencimento da história da cidade baseada no mito do pioneiro. Entretanto, o que se observou não foi uma mera reprodução das idéias dominantes. Este arquétipo, que também compõe a fala dos trabalhadores, serviu, contraditoriamente, para legitimar suas reivindicações do reconhecimento de sua presença, como sujeitos, no passado da cidade.

Nessa disputa, os trabalhadores procuraram inserir mais do que nomes de familiares no elenco dos pioneiros da cidade. Eles buscaram trazer para o âmbito da memória de Foz do Iguaçu o trabalho realizado por pessoas simples e humildes: agricultores, marceneiros, pedreiros, lavadeiras. 
As recordações dos trabalhadores apontaram, também, os limites e a capacidade de convencimento da memória dominante. O esforço de confundir o passado da cidade com a história do desenvolvimento turístico não encontrou aceitação entre eles. Noutra direção, as histórias de vidas dos trabalhadores entrevistados indicaram que, até o final dos anos de 1960, a sua sobrevivência dependia do trabalho nas madeireiras e da atividade agrícola de subsistência. Muitas vezes, para sobreviver, estes trabalhadores se desdobravam em mais de uma frente de trabalho, conjugando os afazeres nas roças com outras atividades, como a comercialização de sua produção excedente, na cidade de Puerto Iguazu (AR). Aliás, também o comércio fronteiriço foi mostrado como alternativa de sobrevivência, principalmente, a partir do fechamento das madeireiras.

Nas lembranças dos entrevistados, o turismo apareceu como uma atividade recente, impulsionada por um conjunto de fatores externos, que muito pouco se articulam com a idéia de vocação desenvolvida pela memória dominante. Sob o olhar dos trabalhadores, o turismo só se tornou uma atividade econômica relevante para o desenvolvimento da cidade a partir de 1970. Para eles, essa década marca o início de um processo de grandes transformações, na cidade. A construção da Usina de Itaipu e o turismo foram lembrados como fatores determinantes do crescimento de Foz do Iguaçu. Contudo, esse crescimento, quando confrontado com o cotidiano vivido na cidade e expresso nas memórias dos trabalhadores, mostrou-se contraditório.

Nas memórias dos trabalhadores, a cidade turística realizava-se como um espaço organizado para atender as necessidades dos seus visitantes e não necessariamente dos seus moradores. O período caracterizado pelo crescimento da cidade e da atividade turística foi lembrado como uma época marcada, também, por muitas dificuldades e sacrifícios. Em função da grande especulação imobiliária, a moradia só era possível, para a maioria dos 
trabalhadores, em loteamentos periféricos e nas favelas. Durante anos, tiveram eles que lutar para transformar o ambiente precário desses loteamentos, abertos sem a instalação de qualquer infra-estrutura - água, luz, esgoto, asfalto, escolas e posto médico. Outros dilemas desse processo que levou à formação de Foz do Iguaçu como polo turístico também foram expressos, nos relatos dos trabalhadores. Suas narrativas sobre as experiências de trabalho, nos setores ligados diretamente ao turismo, não deixaram de frisar o sentimento de indignação, diante das condições de trabalho.

Assim, contrapondo as histórias de vida dos trabalhadores à memória oficial da cidade de Foz do Iguaçu, deparei-me com algo mais complexo do que a negação definitiva desta visão do passado da cidade. Suas lembranças não negaram a imagem da cidade turística, mas refizeram-na, sob um outro ponto de vista. E nessa perspectiva, os trabalhadores foram incorporados, como novos personagens, à memória da cidade. Este esforço, porém, não foi feito sem expor as contradições cuidadosamente silenciadas pela memória dominante. 


\section{REFERÊ N CIAS}

\section{Monografias}

ACÁCIO Pedroso: exemplo de uma vida na história de Foz. Painel. Foz do Iguaçu, n. 27, p.12, abril 1976.

ALBERTI, Verena. História oral: a experiência do CPDOC. Rio de Janeiro : FGV : CPDOC, 1990. 202p.

ALENCAR, Chico. 'Memória'. Foz do Iguaçu : Fundação Cultural de Foz do Iguaçu, 1994. Foz 80 Anos - Memória. Editorial, p. 2. (Projeto Memória. Volume 1).

BARROS, Myriam Moraes L. de. 'Memória e família'. Estudos Históricos. Rio de Janeiro, v.2, n.3, p.29-41, 1989.

BERMAN, Marshall. Tudo que é sólido desmancha no ar: a aventura da modernidade. São Paulo : Cia. das Letras, 1993. 360p.

BICALHO, Maria Fernanda Bicalho. 'As Câmaras Municipais no Império Português: o exemplo do Rio de Janeiro’. Revista Brasileira de História. São Paulo, v.18, n.36, p.251-280, 1998.

BOSI, Ecléa. Memória e sociedade: lembranças de velhos. 3.ed. São Paulo : Cia. das Letras, 1994.

BOYER, Marc. História do turismo de massa. Bauru (SP): EDUSC, 2003. 170p.

BRASIL, Saulo Martins. 'Colônia Militar de Foz do Iguaçu 1889: o começo'. Memória de Foz do Iguaçu. Foz do Iguaçu, 1.etapa., p. 8-12, jun.1982.

'1888: 324 pessoas moravam em Foz'. Memória de Foz do Iguaçu. Foz do Iguaçu, 1.etapa, p.38-40, jun. 1982.

CARDIN, Eric G. Sacoleiros e laranjas na Tríplice Fronteira: uma análise da precarização do trabalho no capitalismo contemporâneo. 2006. 170f. Dissertação (Mestrado em Sociologia)-Faculdade de Ciências e Letras, Universidade Estadual Paulista Júlio Mesquita (UNESP). Araraquara (SP), 2006.

CATTA, Luiz E. O cotidiano de uma fronteira: a perversidade da modernidade. 1994. 138f. Dissertação (Mestrado em História)-Centro de Filosofia e Ciências Humanas, Universidade Federal de Santa Catarina. Florianópolis (SC), 1994.

CHESNEAUX, Jean. Devemos fazer tabula rasa do passado? Sobre a história e os historiadores. São Paulo : Ática, 1995.

COLODEL, José Augusto. Obrageros \& companhias colonizadoras: Santa Helena na história do Oeste Paranaense até 1960. Santa Helena (PR): Prefeitura Municipal de Santa Helena, 1988. 
DIAS, Edmundo Fernandes. Política brasileira. Embate de projetos econômicos. São Paulo: Instituto José Luís e Rosa Sundermann, 2006. 240p.

FERREIRA, Marieta de M.; FIGUEIREDO, Janaína P. Amado B. de. (Org.). Usos e abusos da história oral. Rio de Janeiro : FGV, 1996.

FOZ DO IGUAÇU (Prefeitura Municipal de) Foz do Iguaçu: Retratos. Foz do Iguaçu : Campana \& Alencar, 1997.

Foz 80 Anos. Memória [1914-1994 - Foz do Iguaçu: Terra das Cataratas]. Foz do Iguaçu : Fundação Cultural de Foz do Iguaçu, 1994. (Projeto Memória. V.1).

GLEZER, Raquel. 'O campo da História' Cadernos de História de São Paulo. São Paulo, n.1, p.9-14, 1992.

GONZÁLEZ, Emilio. Memórias que narram a cidade: experiências sociais na constituição urbana de Foz do Iguaçu/PR (1970 - 2000). 2005. 205p. Dissertação (Mestrado em História)-Pontifícia Universidade Católica de São Paulo. São Paulo, 2005.

HALBWACHS, Maurice. Memória coletiva. São Paulo : Vértice : Revista dos Tribunais, 1990. 189 p.

HALL,Stuart. Notas sobre la desconstrucción de 'lo popular'. In: SAMUEL, Raphael. Historia Popular y Teoria Socialista. Barcelona : Crítica, 1984, p.93-113.

HOUAISS, Antonio. Dicionário Houaiss: sinônimos e antônimos da língua portuguesa. Rio de Janeiro : Objetiva, 2003. 968p.

JOUTARD, Philippe. História oral: balanço da metodologia e da produção nos últimos 25 anos. FERREIRA, Marieta de M.; FIGUEIREDO, Janaína P. Amado B. de. (Org.). Usos e abusos da história oral. Rio de Janeiro : FGV, 1996, p.43-62.

LE GOFF, Jacques. História e memória. 4.ed., Campinas (SP) : EDUNICAMP, 1996. 476p.

LIMA, Perci. Foz do Iguaçu e suas histórias. Foz do Iguaçu : Serzgraf, 2001. 192p.

MANARIN, Odirlei. Peões da barragem. 2007. 130p. Dissertação (Mestrado em História)Programa de Pós Graduação em História, Universidade Estadual do Oeste do Paraná. Marechal Cândido Rondon, 2008.

MARX, Karl. O 18 Brumário de Luís Bonaparte. 5.ed. Rio de Janeiro : Paz e Terra, 1986.

MEMÓRIA DE FOZ DO IGUAÇU. Foz do Iguaçu, n.3, abril.1983.

. Foz do Iguaçu, 2.etapa, dez. 1982.

. Foz do Iguaçu, 1.etapa, .jun. 1982.

MENEZES, Alfredo da Mota. A herança de Stroessner: Brasil-Paraguai, 1955-1980. Campinas (SP) : Papirus, 1987. 186p.

MILLS, Wright. A nova classe média. 2.ed., Rio de Janeiro : Zahar, 1976. 380p. 
MONIZ BANDEIRA, L. A. Estado nacional e política internacional na América Latina: o continente nas relações Argentina-Brasil (1930-1992). 2.ed.. São Paulo : Ensaio, 1995, 336p.

O INÍCIO da promoção turística. Painel. Foz do Iguaçu, n.53, p.7-8, jun.1978.

POLLAK, Michael. Memória, esquecimento, silêncio. Estudos Históricos. Rio de Janeiro, v.2, n.3, p.3-15, 1989.

PORTELLI, Alessandro. 'O massacre de Civitella Val di Chiana (Toscana: 29 de junho de 1944): mito, política, luto e senso comum.’ In: FERREIRA, Marieta de M.; FIGUEIREDO, Janaína P. A.B. de. (Org.). Usos e abusos da história oral. Rio de Janeiro: FGV, 1996, p.103-130.

.'Tentando aprender um pouquinho. Algumas reflexões sobre Ética na História Oral.' Projeto História. São Paulo, n.15, p.13-50, out. 1995.

- 'Sonhos urcrônicos: memória e possíveis mundos dos trabalhadores.' Projeto História. São Paulo, n.10, p.41-58, dez. 1993.

RABOSSI, Fernando. 'Dimensões da espacialização das trocas. A propósito de mesiteros e sacoleiros em Ciudad del Este'. Ideação. Foz do Iguaçu, v.6, n.6, p.151-176, 2004.

RIBEIRO, Maria de Fátima. Memórias do concreto: vozes na construção da Itaipu. Cascavel (PR) : EDUNIOESTE, 2002. 116p. (Coleção Thésis).

ROMERO, José L. Latinoamérica: las ciudades y las ideas. 2.ed. Buenos Aires : Siglo XXI, 2005. 416p.

RONCAYOLO, Marcel. Enciclopédia Einaudi. Lisboa : Imprensa Nacional : Casa da Moeda, 1986, v.8, p.396-487.

SANTOS, Elza Pereira; FRIZON, Ivete Ana; OLIVEIRA, Izaura Martins. Foz do Iguaçu: coletânea de dados. Curitiba (PR) : Módulo : Educacional, 1993.

SCHMITT, Judite V. Os atingidos por Itaipu: história e memória. Oeste do Paraná, décadas de 1970 a 2000. 2008. 132p. Dissertação (Mestrado em História)-Programa de Pós Graduação em História, Universidade Estadual do Oeste do Paraná. Marechal Cândido Rondon, 2008.

SCHIMMELPFENG, Ottília. Retrospectos iguaçuenses: narrativas históricas de Foz do Iguaçu. Foz do Iguaçu : Tezza, 1990.77p.

SILVA, Elen. Trabalhadores na fronteira: experiências dos sacoleiros e laranjas em Foz do Iguaçu e Ciudad Del Este (1990-2006). 2008. 137p. Dissertação (Mestrado em História)-Programa de Pós Graduação em História, Universidade Estadual do Oeste do Paraná. Marechal Cândido Rondon, 2008.

SILVA, Carlos A. Franco. 'Trajetórias geográficas do pioneiro André Antonio Maggi na abertura da fronteira do oeste paranaense.' GEOgraphia. Rio de Janeiro, ano II, n.4, p. 89-102, 2000. 
SOUZA, Edson B. C de. A região do lago de Itaipu: as políticas públicas a partir dos governos militares e a busca da construção de um espaço regional. 1998. 146p. Dissertação (Mestrado em Geografia)-Centro de Filosofia e Ciências Humanas, Universidade Federal de Santa Catarina. Florianópolis (SC),1998.

TESIN, Renata Campos. (Org.). Foz do Iguaçu: terra das Cataratas. Secretaria Municipal de Educação de Foz do Iguaçu. Ensino de História e Geografia 2001-2004. (Série A aventura de Aprender). Suplemento do Município de Foz do Iguaçu, 2001.

THOMSON, Alistair. 'Recompondo a memória: questões sobre a relação entre a história oral e as memórias.' Revista Projeto História. São Paulo, n. 15, p.51-71, abr. 1997.

THOMPSON, Edward P. Costumes em comum - estudos sobre a cultura popular tradicional. Tradução: Rosaura Eichenberg. São Paulo : Cia das Letras, 1998. 528p.

WACHOWICZ, Ruy C. Obrageros, mensus e colonos. História do oeste paranaense. Curitiba (PR) : Vicentina, 1982. 206p.

WEBBER, Darcilo. Foz em números. O mais completo banco de dados estatísticos sobre o município de Foz do Iguaçu. Foz do Iguaçu (PR) : Camaleão, 2003, 126p.

WEBER, Max. A ética protestante e o espírito do capitalismo. São Paulo : Cia. das Letras, 2004.

WESTPHALEN, Cecília Maria. História documental do Paraná: primórdios da colonização moderna da região de Itaipu. Curitiba (PR) : SBPH-PR, 1987. 100p.

WILLIAMS, Raymond. O campo e a cidade: na história e na literatura. São Paulo : Cia. das Letras, 19989. 439p.

\section{Monografias (relatos de viajantes)}

ABREU, Antonio Cândido Ferreira de. 'Colônia Militar de Foz do Iguaçu - notas de viagens'. Boletim do Instituto Histórico, Geográfico e Etnográfico Paranaense. Curitiba (PR), v. XXII, p.129-135, 1974.

- 'Visita ao Salto de Santa Maria.' Boletim do Instituto Histórico, Geográfico e Etnográfico Paranaense. Curitiba (PR), v. XXII, p.117-127, [1905] 1974.

. A foz do Iguaçu: ligeira descrição de uma viagem feita de Guarapuava à Colônia do Iguaçu em novembro de 1892. Curityba : Impressora Paranaense, 1896.

ASSIS, Dilermano. Nas barrancas do Alto Paraná. São Paulo : Empreza Gráphica Paulo Pongetti e Cia, 1926.

BALlÃO, Jaime. A Fóz do Iguassu e as Cataratas do Iguassu e do Paraná: descrições de viagem. Curityba : Typographia d'A República, 1921. 60p.

BRITO, José Maria de. [1938]. 'Descoberta de Foz do Iguassú e fundação da Colônia Militar'. Boletim do Instituto Histórico, Geográfico e Etnográfico Paranaense. Curitiba, v. XXXII, p.45-72, 1977. 
CABANAS, João. A coluna da morte. Rio de Janeiro : [S.n.], 1927.

FIGUEIREDO, José de Lima. Oeste paranaense. São Paulo : Nacional, 1937. 197p.

(Biblioteca Pedagógica Brasileira, Série 5, Brasiliana, v. 97).

FRANCO, Arthur Martins. Recordações de viagens ao Alto Paraná. Curitiba : Imprensa UFPR, 1973. 78p.

MARTINEZ, César Pietro. Sertões do Iguassú. São Paulo : Cia. Gráfica-Editora Monteiro Lobato, 1925. 192p.

MURICY, José Candido da Silva. [1896]. Viagem ao país dos jesuítas. Curitiba : Imprensa Oficial do Estado do Paraná, 1975.

- A Foz do Iguassú: ligeira descripção de uma viagem feita de Guarapuava a Foz do Iguassú em novembro de 1892. Curityba : Impressora Paranaense, 1896.

NASCIMENTO, Domingos. Pela fronteira: Paraná. Curityba : Typographia d'A República, 1903. 228p.

NOGUEIRA, Júlio. Do rio Iguassú ao Guayra. Rio de Janeiro : Typographia Carioca, 1920.

SILVEIRA NETTO, Manoel de Azevedo. Do Guairá aos Saltos do Iguassú. Curityba :Typographia do Diário Oficial, 1914. Reedição: Curitiba : Fundação Cultural de Curitiba, 1995. (Coleção Farol do Saber). 107p.

TAUNAY, Visconde de. Curiosidades naturaes do Paraná e excursão no rio Iguassu. Rio de Janeiro : Typographia Laemmert, 1890.

\section{Documentos jurídicos e outros documentos oficiais}

BOLETIM do Instituto Histórico, Geográfico e Etnográfico Paranaense. Curitiba (PR), volumes XXII (1974); XXXII (1977).

BRASIL. Decreto $\mathbf{N}^{0}$ 1, de 7 de fevereiro de 1991 [Lei das Royalties]. Regulamenta o pagamento da compensação financeira instituída pela Lei no 7.990, de 28 de dezembro de 1989, e dá outras providências. Publicado no D.O.U. de 14.1.1991. Disponível em: http://www.planalto.gov.br/ccivil 03/decreto/1990-1994/D0001.htm

BRASIL. Ministério da Guerra. Relatório I do ano de 1894. Apresentado ao Presidente da República dos Estados Unidos do Brazil pelo Ministro Bernardo Vasques, em maio de 1895. [Este Relatório integra o acervo digital do Projeto de Imagens de Publicações Oficiais Brasileiras do Center for Research Libraries (CRL) e do Latin American Microform Project (LAMP), sob patrocínio da Fundação Andrew W. Mellon]. Disponível em: http://brazil.crl.edu/bsd/bsd/hartness/index.html.

FOZ DO IGUAÇU (Prefeitura Municipal de). Lei No 1.224, de 12 de julho de 1985. Dispõe sobra a criação da Fundação Cultural de Foz do Iguaçu. Disponível em <http://www.ceaam.net/foz/legislacao/index.php > Acesso em 12 fev.2007. 
Secretaria Municipal de Turismo. Inventário da Oferta Turística de Foz do Iguaçu. Foz do Iguaçu: SMT, 2006.

Relatório estatístico do desenvolvimento de Foz do Iguaçu no período de 19741979. Foz do Iguaçu, 1980.

INSTITUTO BRASILEIRO DE GEOGRAFIA E ESTATÍSTICA (IBGE). Censo Demográfico de 1960. Curitiba (PR): IBGE: Departamento de Estatística da População, 1960. VII Recenseamento Geral : Série Regional. V.1, tomo XIV.

Enciclopédia dos municípios brasileiros. Curitiba (PR) : IBGE, 1959, v.31.

. Estado do Paraná: censos demográficos e econômicos. Rio de Janeiro : Conselho Nacional de Estatística : Serviço Nacional de Recenseamento, 1955. Série Regional, v.XXVI.

. Sinopse Estatística de Foz do Iguaçu - 1950. Curitiba (PR) : IBGE, Departamento Estadual de Estatística do Estado do Paraná, 1950.

INSTITUTO PARANAENSE DE DESENVOLVIMENTO ECONÔMICO E SOCIAL. (IPARDES). Balanço do Mercado de Trabalho de Foz do Iguaçu. Relatório II. Curitiba : IPARDES, abril 1984.

. Balanço da Situação Social de Foz do Iguaçu. Relatório I. Curitiba : IPARDES, abril 1984a.

INSTITUTO POLO INTERNACIONAL IGUASSU. Iguassu: um destino para o mundo. Foz do Iguaçu : Teática, 2001. (V.1).

\section{Sítios na Internet.}

BRASIL. Presidência da República.

http://www.presidencia.gov.br. http://www.presidencia.gov.br/legislacao. http://www.planalto.gov.br/ccivil_03/decreto/1990-1994/D0001.htm

. Ministério da Marinha. Capitania Fluvial dos Portos do Rio Paraná http://www.mar.mil.br/cfrp/historico.htm.

CÂMARA MUNICIPAL DE FOZ DO IGUAÇU. http://www.camarafoz.pr.gov.br/ http://www.ceaam.net/foz/legislacao/index.php

CENTER FOR RESEARCH LIBRARIES (CLR). http://www.crl.edu/ http://brazil.crl.edu/bsd/bsd/hartness/index.html.

INSTITUTO BRASILEIRO DE GEOGRAFIA E ESTATÍSTICA. http://www.ibge.gov.br . http://www.ibge.gov.br/cidadesat/default.php.

PREFEITURA MUNICIPAL DE FOZ DO IGUAÇU. 
http://www2.fozdoiguacu.pr.gov.br

http://www2.fozdoiguacu.pr.gov.br/Turismo/imagens 